\title{
THE STONE AGE OF INDONESIA
}


H.R. van Heekeren - 978-90-04-28643-6 Downloaded from Brill.com๑4/26/2023 09:07:18AM via free access 


\title{
IERIIINDRLINGRI
}

VAN HET KONINKLIJK INSTITUUT VOOR

TAAL-, LAND- EN VOLKENKUNDE

\author{
DEEL XXI
}

\section{THE STONE AGE OF INDONESIA}

BY

H. R. VAN HEEKEREN

'S.GRAVENHAGE - MARTINUS NIJHOFF - 1957 
H.R. van Heekeren - 978-90-04-28643-6 Downloaded from Brill.com๑4/26/2023 09:07:18AM via free access 


\section{PREFACE}

Indonesian prehistoric archaeology was only a little-known and recently developed science in the days that Dr P. V. van Stein Callenfels took the first tentative steps in this field of study, and ever since other scholars walked in his steps and helped to advance our prehistoric knowledge.

Dr W. J. A. Willems, who was the first to introduce an entirely new scientific method of excavation, Dr A. N. J. Thomassen à Tuessink van der Hoop, who distinguished himself by field-work in Sumatra and later as the Djakarta Museum's general oracle and Prof. Dr G. H. R. von Koenigswald who enjoys a world-wide recognition owing to his discoveries of a series of fossil human remains and palaeoliths and his palaeontological studies, were my predecessors whom I feel it my pleasant duty to remember here because I learned so much from them.

Among the foreign scholars who had a great part in the progress of prehistoric research I wish to mention in particular Prof. Dr Robert Heine Geldern, Paul and Fritz Sarasin and Prof. Dr Hallam L. Movius Jr. They all have largely contributed to the knowledge of prehistoric Indonesia, but the results of their studies and examinations are scattered in numerous periodicals and scientific papers, which unfortunately are not always easily obtained or are written in foreign languages not always accessible to all and one.

The purpose of this study is to summarize all data concerning the knowledge of Indonesian prehistory, as derived from that which has been published by others on this subject as well as from my own experiences in this field.

The subject-matter is divided into three consecutive stages: the Palaeolithic, Mesolithic and Neolithic.

The theatre of the main cultural development has been, and still is, Java and Sumatra. Many islands, however, are situated at quite a distance from that centre of development; they are inhabited by peoples living in great isolation, who had their traditions handed down from one generation to the next. In some cases these more or less static and conservative cultures are, at least in material and economical aspects, reminiscent of prehistoric civilizations. 
Special thanks are due to the Director of the Wenner Gren Foundation 'The Viking Fund', New York, who provided me with grantsin-aid in 1951 and 1952. Thanks again are due to Mr. M. W. F. Tweedie, Director of the Raffles Museum \& Library, Singapore and Mr. G. de G. Sieveking, Curator of Museums, Perak, who both read and criticized the entire manuscript and offered many valuable suggestions. I am also greatly indebted to Prof. Hallam L. Movius Jr., Harvard University, Cambridge, Mass., U.S.A., for his scientific help and his moral support and friendship in those post-war days when I left the prisoner-of-war camps in Siam and Japan and had to make a fresh start.

Though I cannot acknowledge all my literary debts, I do wish to express my thanks to the friends and relations who have given me their aid: the Head of the Archaeological Service of Indonesia, Mr. Soekmono and the Board of Directors of the Lembaga Kebudajaan Indonesia „Bataviaasch Genootschap van Kunsten en Wetenschappen”, Djakarta, for the many photographs I needed for this manuscript and to $\mathrm{Mr}$. Basoeki for the illustrations and maps.

This volume will before long be followed by a second volume dealing with the Bronze-Iron Age of Indonesia.

Djakarta, January 1957

H. R. VAN HEEKEREN. 


\section{CONTENTS}

Preface . . . . . . . . . . . . . . . . . . . V

Contents . . . . . . . . . . . . . . . . . . VII

Introduction . . . . . . . . . . . . . . . . . 1

1. Cenozoic . . . . . . . . . . . . . . . . . 1

2. The Lower Pleistocene . . . . . . . . . . . . 7

I. Palaeolithic . . . . . . . . . . . . . . . . . 20

1. The Middle Pleistocene . . . . . . . . . . . . 20

2. The Upper Pleistocene . . . . . . . . . . . . 37

3. References and Selected Bibliography . . . . . . . 55

II. Mesolithic . . . . . . . . . . . . . . . . . . 67

Introduction . . . . . . . . . . . . . . . . . 67

1. The Hoabinhian Pebble Industry . . . . . . . . 67

2. The Sampung Bone Industry . . . . . . . . . 75

3. The Flake and Blade Industries . . . . . . . . . . . 86

4. References and Selected Bibliography . . . . . . . 109

III. Neolithic . . . . . . . . . . . . . . . . . . . . . 116

Introduction . . . . . . . . . . . . . . . . . 116

1. Excavations .. . . . . . . . . . . . . . . 117

2. Neolithic Surface Finds . . . . . . . . . . . . 120

3. Neolithic Traditions in Indonesia . . . . . . . . 126

4. Neolithic Tools . . . . . . . . . . . . . . . 127

5. References and Selected Bibliography . . . . . . . 134

IV. An attempted Chronology of the Stone Age of Indonesia 140

1. The Pleistocene Period . . . . . . . . . . . . 140

2. The Holocene Period . . . . . . . . . . . . 141

Plates 
H.R. van Heekeren - 978-90-04-28643-6 Downloaded from Brill.com๑4/26/2023 09:07:18AM via free access 


\title{
INTRODUCTION
}

\begin{abstract}
"During Upper-Pliocene times Java emerged from the sea and was linked to the southern Asiatic mainland. The newly formed peninsula became the habitat of mammals which migrated from the southern portion of Asia."
\end{abstract}

Hellmut de Terra.

\section{CENOZOIC}

eologically, Indonesia is complex. It consists of groups of large and small islands, situated between the Asiatic and the Australian Continents, and extends from $6^{\circ} \mathrm{N}$. lat. to $11^{\circ} \mathrm{S}$. lat. and $95^{\circ}$ to $140^{\circ}$ E. long. The Archipelago is a heterogeneous geosynclinal area divided into two dissimilar regions. One, the northwestern region, has been stable since Pleistocene times; it has a quiet, regular submarine relief which consists of two Continental Shelves of extensions of the beach below the sea-level, caused by denudation and sedimentation. The Continental Shelves are the Sunda Shelf uniting Borneo, Sumatra and Java with the Malay Peninsula, and the Sahul Shelf joining Australia, New Guinea and the Aru Islands. The second region, situated in the Southeast, is unstable; it has a considerably active submarine relief and comprises Celebes, the Moluccas and the eastern string of the Lesser Sunda Islands. The small deep-sea basins and troughs east of Celebes are especially notable. 1

The entire area has an equatorial insular monsoon climate combined with a high temperature, a high humidity and a heavy rainfall. The islands are covered with rain forests, except the eastern part of the Lesser Sunda Islands where savanna landscapes prevail due to the influence of the Australian winter anticyclones. Along the coastal plains mangroves grow, and steep mountains of volcanic origin arise, some exceeding the tree-line. On New Guinea some mountains even reach as high as the snow-line.

1 Umbgrove; '49, $1-4$. 


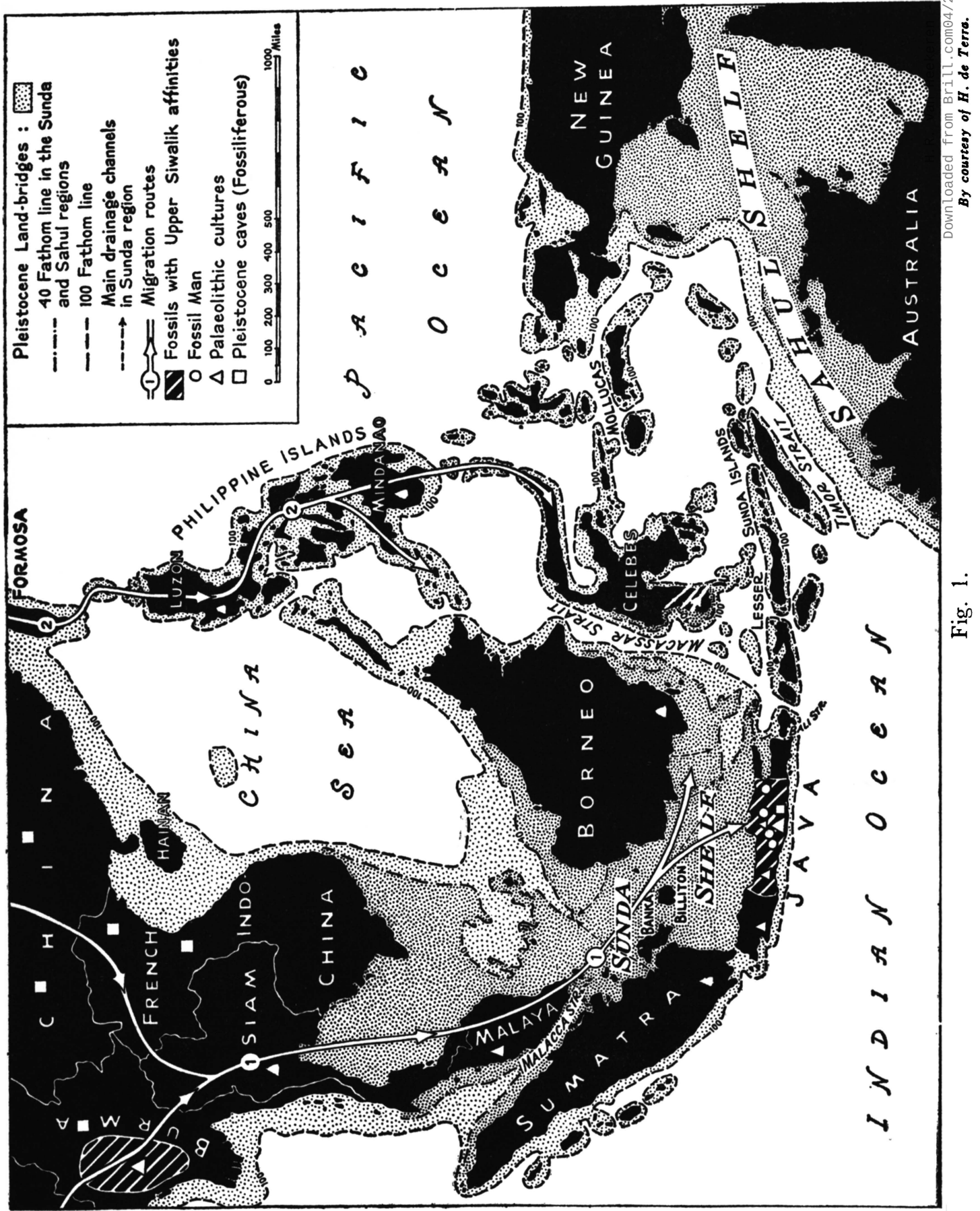


The fauna of the Greater Sunda Islands corresponds roughly with that of Further India while nearer to New Guinea a penetration of Australian elements is noticeable. In Celebes and Timor the extreme outposts of Australian fauna are to be found. Irregular climatic conditions and the presence of deep-sea basins account for the fact that islands like Celebes, Flores and Timor are less suited to accommodate the larger herbivorous mammals. There sometimes peculiar endemic forms occur. ${ }^{2}$

Indonesia's present population consists of about 80 million inhabitants of which as many as 45 million live in Java. The largest portion comprises Malay (Palae-Mongolian) peoples who are far from homogeneous. They predominate in the western area including Celebes, whereas New Guinea and the adjoining islands are inhabited by Papua-Melanesian peoples. The central zone to the east of Celebes, displays a strong mixture of races.

Java is a part of the Great Sunda Shelf. Like nearly all the other islands of the Archipelago, it emerged from the sea late and contributed little to the origin and evolution of the mammals. From the beginning its fauna immigrated from the Asiatic Continent by way of landbridges. Such a landbridge existed at the end of Tertiary times, but it was severed afterwards. Also during the Pleistocene Java must have been connected repeatedly by landbridges with the Malay Peninsula. This has to be ascribed to a combination of orogenic movements and lowerings of the sea-level during the Glacial stages. The former, however, greatly overshadow the effects of the eustatic oscillations of the latter.

At the close of the Miocene Period the first groups of islands emerged from the sea in places where at present the western Java Plateau and the Southern Mountains of Central Java (Gunung Sewu) are situated. North of these islands was a shallow strait with a few scattered small islands, the forerunners of two anticlines which later developed into the Kendeng Hills and the Northern Limestone Mountains. The former constitute a folded ridge which stands from 350 to 400 metres high and stretches from Semarang in Central Java to near Surabaja in East Java. Both mountain ranges are intersected by the Solo River. There are indications that the tectonic movements of the Kendeng Hills occurred mainly below the sea-level during Tertiary times. Since the Middle Pliocene these tectonic movements exerted a greater pressure and caused the enlargement of the emerged parts of Java. Finally, these parts developed into a narrow peninsula as a younger extension of the Asiatic

2 de Beaufort; '26. 
Continent. The first mammals then had the opportunity to reach Java overland. The T $\mathrm{ji}$ Djolang fauna, found north of Bandung, consisting of Merycopotamus, Stegodon and a primitive Hippopotamus, and the Kali Glagah fauna, known from one site in the neighbourhood of Tegal, Central Java, with Archidiskodon, Mastodon (Trilophodon) bumiajuensis and Hippopotamus simplex are of Early Pleistocene age. Von Koenigswald correlates the T $\mathrm{ji}$ Djolang fauna with the Tatrot Zone of the Siwalik Hills in India. The situation is not entirely clear, and there is no complete agreement yet concerning the stratigraphy of the Siwalik Hills and the demarcation of the Tertiary and Quarternary beds. It has been internationally agreed upon, however, that the Villafranchian marks the beginning of the Pleistocene (18th Session, 1948, International Geological Congress, London). The typical Villafranchian genus Archidiskodon is already present in Java in the $\mathrm{T} \mathrm{ji}$ Djolang and the Kali Glagah faunas, which also deserve a place in the Lower Pleistocene. But the Javanese forms lack the horses, camels, giraffes and most of the antilopes, which were animals of the open plains. ${ }^{3}$ On this basis, too, the Tatrot Zone marks the beginning of the Pleistocene.

In this period the eastern part of Java began to emerge from the sea, attended by a phase of powerful volcanic activity which resulted in the formation of belts of volcanoes. One third of the surface of Java is covered with their deposits. Since then the geologic formation of Java was influenced by volcanic activity, foldings, uplifts and downwarps which divided it into a number of synclines and anticlines in an East-West direction. Inland seas filled the depressions. Interfering processes like fluviatile erosion and fluctuations of the sea-level, sometimes happening simultaneously, effected rapid and considerable changes in the topography of Java.

Owing to the Glacial Stage the shallow seas of the Continental Shelves ran dry and this led to the formation of the Greater Sunda region. Now the large mammals were again able to reach Java overland, and as far as possible they followed the alluvial tracts of the newly emerged surface. 4

The Snellius Cruise 5 succeeded in establishing the topography of the Sunda region as well as the former river system by gravimetric

3 Hooijer and Colbert; '51, 533-538. Hooijer; '52, 436-443.

4 de Terra; '43b, 440-41. Von Koenigswald; '35, 188-98.

5 de Terra; '43b, 461. 
investigations. The theory of both J. Croll 6 and A. Penck 7 has been put to the test by G. A. F. Molengraaff and M. Weber on orohydrographic phenomena and by zoo-geographic research. It not only appeared that the boundaries of the Sunda area coincide with the 40 fathom isobath, but also that its coasts bear no traces of elevations. However, there only occur depressions and courses of drowned rivers. 8 Next it became apparent that a main stream had existed formerly which received the rivers of East Sumatra and the Kapuas River of West Borneo. Biological studies have shown that the present piscine fauna of these rivers is still the same. The main stream had its source on a plateau where Bangka and Billiton are situated at present. This powerful stream ran in a northerly direction and debouched into the southern part of the South China Sea; another stream ran southwards and debouched into Macassar Strait.

According to Molengraaff and Weber, the lowering of the sea-level amounted to 72 metres during the Fourth Glacial period and $\mathrm{H}$. de Terra calculated that it probably exceeded 100 metres during the Second Glacial, this being the most extensive retreat of the sea.9 (Fig. 1).

The current belief that the Tropics have not been subjected to important climatological fluctuations during the Pleistocene should at least be doubted considering the present knowledge of this matter. The investigations of F. E. Zeuner 10 have raised the possibility that cyclic processes, caused by climatic conditions, have affected the whole globe. Eric Nilsson 11 has made a thorough examination of this subject in Abyssinia, Tanganyika and Kenya. Apart from important tectonic movements, he established the existence of three Pluvials and a number of post-pluvial periods during the Pleistocene Period. In his opinion, the rythmic climatologic fluctuations under discussion existed simultaneously all over the world. Of course, the geographic position of the region must also be taken into consideration. Thus in the northern and high mountanous regions, Glacials will occur instead of Pluvials. In the Far East notably in Kashmir and Upper Burma, $\mathrm{H}$. de Terra could establish four Glacials, in the Irrawaddy Basin near Chauck three Pluvials, whilst G. B. Barbour 12 and P. Teilhard de Chardin reached the same results concerning the Yangtze Valley, South China.

6 Brouwer; '26, 1--33. Croll; 1875.

7 Penck; '33, 324-39.

8 Molengraaff und Weber; '21, 395-439. de Terra; '43b, 459-62.

$\theta$ de Terra; 43b, 459--61.

10 Zeuner; '46.

11 Nilsson; '41, 1-23.

12 Barbour; '35, 1-112. 
Along zoo-geographical lines, E. Stresemann 13 decided on the following working hypothesis: in the Early Pleistocene, during the first Dry Period, the Tropics were blanketed by grasslands. The grassland birds could choose between two passages, one from Tenasserim, Burma and Malaya to Sumatra and the Lesser Sunda Islands; the other from South China via Formosa to the Philippines, Celebes and the Lesser Sunda Islands. The same passages are recorded by C. G. D. van Steenis for the extension of the alpine flora. ${ }^{14}$

The first Dry Period was followed by the first Pluvial. The rain forests spread to Malaya, North and West Borneo, the Philippines and North Celebes. The savanna landscapes disappeared and the grassland birds with them. This was followed by a second Dry Period, milder than the previous one. The grassland birds made their appearance again. At that time there was only one passage open to them, the one leading to the Lesser Sunda Islands by way of Formosa and the Philippines, since the other route was obstructed by the rain forests. Hereafter the second Pluvial set in and the rain forests reached the extension which but for human interference they would now occupy. Stresemann assumes at least two Pluvials in the Tropics during the Pleistocene Period. Further investigations will possibly disclose a correlation between these and the Interglacials on the Asiatic Continent.

Julius Schuster 15 found a fossil arboreal flora in Trinil (Java) just above the chief fossil-bearing bone-bed. The flora comprised 54 species, of which 24 still occur on Java at an altitude of 600 to 1200 metres above sea-level. This would mean that Java then had a climate cooler and damper than at present and the temperature would have been $22-18^{\circ} \mathrm{C}$. lower than at present.

Java with its equatorial position and recent emergence from the sea presents a situation of a complicated nature. And it would, therefore, be premature even to propose a correlation between this area and the several periods on the Asiatic Continent.

G. H. R. von Koenigswald 16 subdivides the Pleistocene on Java into Lower, Middle and Upper periods, which are distinguished by three consecutive faunas. The discoveries of a series of fossil early hominids by von Koenigswald and others in the years 1931-38 have placed Java

13 Stresemann; '39, 312-425.

14 van Steenis; '35, 135-263, 289-417.

15 Schuster;' 11.

16 Von Koenigswald; '34, 185-201. Hooijer; '51a, 278. 
in an important position in the world as far as the number of various forms of fossil men is concerned.17

The abundance of fossils, however, has to be ascribed to the exceedingly favourable circumstances which have contributed to the preservation of the remains, and by which they could be mineralized. Catastrophic volcanic eruptions produced mud-flows which swept men and animals away and covered their remains. Hermetically enclosed, the organic elements of the bones have been replaced gradually by mineral salts. This process is only possible under extremely favourable circumstances.

\section{THE LOWER PLEISTOCENE.}

"The hominids of the Sino-Malayan fauna, as far as they are known at present, represent a fairly continuous line proceeding from small types to gigantic ones .......

As to their morphological characters, each larger type seems to be more primitive than the next smaller one. In other words, gigantism is a primitive character which has the tendency to diminish as evolution advances."

Franz Weidenreich.

\section{A. The Putjangan Beds.}

North of Modjokerto in East Java, the Kendeng Hills are at their lowest and near the village of Perning they have an altitude of only 50 to 100 metres. Near Klagenblandong lies a well dissected mountain ridge running from east to west, being part of the Kedungwara anticline. The country, in particular along the road to Sumbertengah, is exposed to such a degree that the stratigraphy can be clearly distinguished. The area under discussion is situated in the eastern part of an old marine strait that once comprised a large part of the Solo valley. In later times it was filled up with fine volcanic material by fluviatile and eolian agencies, until the entire basin was full of sediments. Afterwards, it was temporarily flooded again by the sea.

As demonstrated by J. Duyfjes, 18 the stratigraphy of the Putjangan Beds in this area starting with the upper layers, consists of a sediment

17 Von Koenigswald; '40, 1-232. Hooijer is rather sceptical about a clear distinction between the Djetis- and the Trinil fauna and predicts that "with further increase of our knowledge of the Pleistocene faunas of Java, we shall have a much less cataclysmic picture of the faunal evolution".

18 Duyfjes; '36, 136-49. Von Koenigswald; '40, 47-51. 
of coarse and fine sandstone ( $35 \mathrm{~m}$. thick), a marly tuffaceous sandstone with marine molluscs (10 m. thick), a layer of greenish clay $(5 \mathrm{~m}$. thick), a coarse sandstone layer $(100 \mathrm{~m}$. thick) containing fine-grained and coarse-grained conglomerates and andesite boulders. The lowest section contains deposits of a finely stratified and fine-grained tuffaceous sandstone which constitute the transition to a similar layer $(10 \mathrm{~m}$. thick) which contains clay in some places. Beneath it are marly and clayish tuffaceous sandstones, bearing conglomerates and marine molluscs, and here and there big lumps of coral and andesite rocks the size of a head ( $15 \mathrm{~m}$. thick). Finally, a thick layer of tuffaceous sandstone which at some localities could not be distinguished clearly from the preceding one. At the top of the hill-ridge the fourth layer, consisting of a coarse-grained volcanic sandstone, breaks the surface. Officers of the Geological Survey dug a pit on this spot to collect fossils from this layer. The digging led to the discovery of a fossil infant skull at a depth of only one metre. There could be no mistake this time concerning the Lower Pleistocene age of the skull, because it had been found in situ and the layer had been carefully examined geologically as well as palaeontologically by Duyfjes and von Koenigswald. As a mere precaution, the horizon was investigated again in 1938 by de Terra and Movius, who both arrived at the same conclusion. Complete proof was given by de Terra 19 who, after studying the mineralogical composition of the matrix inside the skull and comparing it with samples taken from the pit, found them identical. The possibility of the skull having been washed away from a more recent horizon into an older layer can therefore be excluded. (Fig. 2). Guide fossils of the Lower Pleistocene Djetis fauna have been found on the spot.

Deposits of the same age as those found near Modjokerto have also been recovered in other places, although of a slightly varied composition. Near Sangiran and Trinil they have been more influenced by volcanic activity. The Trinil layer consists of a mud-flow breccia (100 m. thick), overlain by the well-known Middle Pleistocene Kabuh Beds. The breccia itself covers the Upper Pliocene Kalibeng Beds of marine origin. All layers have been affected tectonically and dip to the south.

North of Solo, the uplift of Sangiran, dome-like and flat on the top, which is $6 \mathrm{~km}$. long and $4 \mathrm{~km}$. wide, was exposed by folding to such a degree that its entire stratigraphy could likewise be clearly distinguished. Here, too, the lowest horizons are of marine origin and are covered by

19 de Terra; '43b, 442-43. 


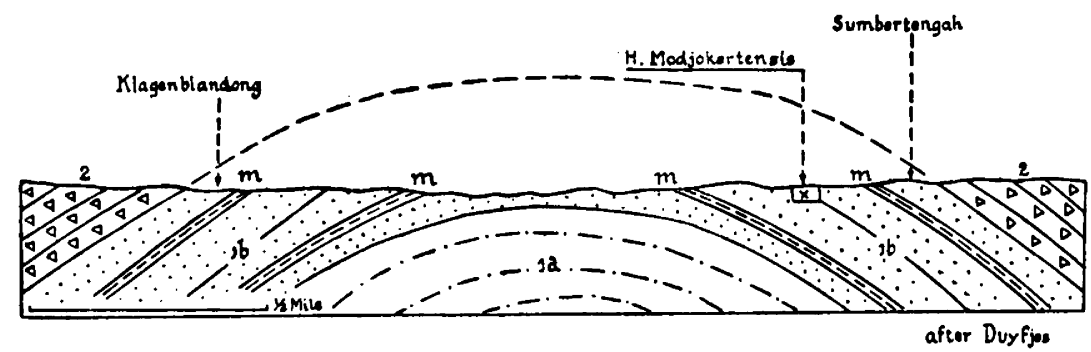

Fig. 2. Geological Section North of Perning near Modjokerto.

1. Lower Pleistocene Putjangan Beds containing the Djetis fauna.

1a. Marine deposits.

1b. Fresh-water deposits; m. marine layers.

2. Middle Pleistocene Kabuh Beds containing the Trinil fauna.

$x$ site where the infant skull of Homo modjokertensis was found.

volcanic tuff-breccia ( $30 \mathrm{~m}$. thick) created by a mud-flow which contains andesite blocks. This laver is immediately followed by a black clay deposited in stagnant pools and marshes, with numerous fresh-water molluscs ( $200 \mathrm{~m}$. thick). It is interrupted by a black clay and the preceding lowest volcanic breccia yielded guide fossils of the Djetis fauna, as well as remains of three different types of early hominids: Meganthropus palaeojavanicus, Pithecanthropus modjokertensis and Pithecanthropus dubius.

Bone-bearing beds consisting of black clay containing fresh-water molluscs have also been found at Trinil, Kritjak and Bandjarbangi and they are exposed in some places on the banks of the Solo River. Near Watualang they occur in three places.

The foot of the Butak Hill also starts with marine beds, overlain by volcanic breccia which have been interrupted by tuff-banks. The stratigraphy consists from top to bottom of a tuff-bank (125 m. thick), a tuffaceous sandstone layer and tuff breccias (75 m. thick), banks of tuff ( $40 \mathrm{~m}$. thick) and sandstone bearing fossils of the Djetis fauna. Thick tuff breccias (200 m. thick) close the horizon.20

\section{B. The Djetis fauna.}

In the entire stretch of the Kendeng Hills there are Putjangan Beds which yield a Lower Pleistocene mammalian fauna. This fauna, however, has not been recognized as a distinct element until recently. L. M. R. Rutten was the first to discover an isolated molar of a primitive Stegodon in the vicinity of Modjokerto in 1927. Cosijn described other fossils from

20 Von Koenigswald; '40, 54. 
the area in 1931-1932; in 1934 von Koenigswald and Cosijn visited this region and collected a large quantity of important material, in particular at Sidorjal. They noticed that the collected fauna included species which did not occur in the Trinil Beds, whilst Stegodon and Hippopotamus were more primitive. Guide fossils are Cervus zwaani, Antilope modjokertensis and Leptobos cosijni. Von Koenigswald has shown that the Djetis fauna is correlated with the Pinjor Zone in India, but as it also includes evidence of South Chinese influences, he named it a SinoMalay fauna.21 For Ursus, Gibbon and Tapirus are absent in South China as well as in Java. The Djetis fauna has been found in the Putjangan Beds near Sangiran with Pithecanthropus modjokertensis and Meganthropus palaeojavanicus, and at Modjokerto with a fossil infant skull. In Western Java this fauna occurred in the Tjitarum Valley near Bandung and Subang. Human artifacts have not been found in these oldest layers.

The complete list of the Lower Pleistocene Djetis fauna reads as follows:

\section{PRIMATES :}

Meganthropus palaeojavanicus von Koenigswald, Pithecanthropus modjokertensis von K., Pithecanthropus dubius von K., Simia satyrus L., Symphalangus syndactylus Desm., Hylabates leuciscus Geoffr., Pithecus pyrrhus Horsf., Macaca irus Cuv., Macaca sp.

\section{PROBOSCIDAE:}

Stegodon trigonocephalus praecursor von K., Elephas sp.

\section{UNGALATA:}

Rhinoceros sondaicus Desm., Rhinoceros kendengensis, Tapirus cf. indicus Desm., Nestoritherium javanensis, Sus brachygnathus Dub., Sus coerti von K., Sus sp., Hippopotamus koenigswaldi Hooijer, Cervus (Rusa) zwaani von K., Cervus (Rusa) probl. von K., Cervus (Rusa) cf. hippelaphus Cuv., Muntiacus muntjak kendengensis Str. Tragulus kanchil Raffl., Antilope modjokertensis von K., Antilope saatensis von $\mathrm{K}$., Antilope sp., Leptobos cosijni von $\mathrm{K}$.

\section{CARNIVORA:}

Epimachairodus zwierzyckii von K., Felis palaeojavanica Str., Felis

21 Von Koenigswald; '40, 55-57, 67-68. 
tigris L., Paradoxurus sp., Arctictis binturong Raffl., Viverricula malaccensis Gml., Viverra div. sp., Hyaena sinensis, Hyaena sp., Megacyon merriami, Ursus cf. kokeni M. et G. Ursus malayanus Raffl., Lutra cf. Palaealeptonyx Dub.

\section{EDENTATA:}

Manis palaeojavanica Dub.

\section{RODENTIA:}

Acanthion brachyrus, Hystrix sp., Rhizomys cf. sumatrensis Raffl.

\section{The Early Hominids.}

a. Meganthropus palaeojavanicus von K.

In April 1941 von Koenigswald discovered a fragment of an enormous, massive and primitive mandible near Sangiran. Two molars and the first premolar were still in situ, while the greater part of the alveolus of the canine was also preserved. The dimensions of this fragment, larger than any observed in a human mandible, surpass even the Heidelberg jaw to a considerable extent; rather they fall within the range of the male gorilla (Fig. 3).

At the alveolus of the first molar the jaw measures no less than $44 \mathrm{~mm}$. in height as against $34 \mathrm{~mm}$. in the Heidelberg specimen. The average thickness is $26.5 \mathrm{~mm}$. as against $18.5 \mathrm{~mm}$. in Heidelberg. The antero-posterior length of the molars totals $33 \mathrm{~mm}$.; in Heidelberg this is $25 \mathrm{~mm}$.

Unusually large, $131 \mathrm{~mm}$., is the circumference at the mental foramen level, surpassing even that of the male gorilla, which never exceeds $121 \mathrm{~mm}$., whilst that of Heidelberg measures $92 \mathrm{~mm}$. The jaw is chinless and the buccal surface rounded; its shape is therefore rather simian. But the mental foramen is located exactly at the half-way level of the mandible, as in Pithecanthropus as well as in modern man. There is no simian shelf, and the premolars are not specialized; the symphysis, showing the beginning of the mental spine, is essentially human. The jaw is slightly higher, but thicker than that of gorilla. It apparently combines characteristics of both anthropoids and hominids. In spite of its enormous dimensions, it should, as its name already indicates, fall within the range of the early hominids, although it is undoubtedly more primitive than Pithecanthropus. 22

22 Weidenreich; '44, 34-55. Hooijer; '51, 265-81. Von Koenigswald: in van Bemmelen; '49, 107. Marks; '53, 26-33. 
The dentition which is present is also considerably larger than that of any man, fossil or modern. The form and pattern of the bicuspidate unspecialized premolar resembles that of Pithecanthropus pekinensis. It is $10.0 \mathrm{~mm}$. long (Heidelberg: $8.1 \mathrm{~mm}$.) and $12.0 \mathrm{~mm}$. broad (Heidelberg: $9.0 \mathrm{~mm}$.). The crown is badly worn and higher than in Heidelberg and Pithecanthropus but on the other hand is surpassed in size by some Krapina molars, as well as by some of modern man. The second premolar is also bicuspid, longer and broader than in Pithecanthropus, and exceeds the maximum values of Pithecanthropus pekinensis. The cingulum is less developed than in Pithecanthropus pekinensis. In spite of wear, it was possible to establish that the first molar had six cusps arranged in a pattern almost identical with that of Dryopithecus. It is $15.0 \mathrm{~mm}$. long (maximum length of Pith. pek. is $13.6 \mathrm{~mm}$.; of Heidelberg $11.6 \mathrm{~mm}$; ; of Pithecanthropus B $12.5 \mathrm{~mm}$.) and $13.5 \mathrm{~mm}$. broad (maximum breadth of Pith. pek. is $12.6 \mathrm{~mm}$; of Heidelberg $11.2 \mathrm{~mm}$; of Pithecanthropus B $13 \mathrm{~mm}$.).

F. Weidenreich reconstructed the entire mandible with the dentition, and from this it appears that the massive impression of the jaw is created by a reduction of the length. The data just given have all been obtained from casts described in Weidenreich's monograph.23 The original remained with von Koenigswald who, because of World War II, had no opportunity to take the measurements himself. Since the jaw has survived the war, we may expect a description by von Koenigswald in the future. It is clear, however, that the mandible belonged to an early form of hominid.

An additional, highly fossilized mandible fragment of Meganthropus was found in September 1952 by Dr P. Marks near Sangiran, north of the village Glagahombo. The jaw fragment was weathered out of a hard conglomerate $11 / 2-2$ metres thick, and strongly cemented, which forms the boundary between the Kabuh and Putjangan Beds. (Pl. 2). The fragment consists of the right side of the mandible, broken off at the distal end, but including the frontmost part of the ramus ascendens, as well as the complete tooth-row P3-M3. The crowns of the teeth except for M3, are broken off. 24

23 Weidenreich; '44, 15. Von Koenigswald: in van Bemmelen; '49, 110.

24 Marks; '53, 26-33. Le Gros Clark; '55, 86-87, 95. The latter does not agree with a generic separation of Meganthropus from Pithecanthropus on the basis of dental morphology. "It may readily be admitted that the available fossil material from Java is not yet adequate to decide finally whether there was more than one genus, or more than one species, of hominid living in Java during the Early Pleistocene. But from general consideration the pro- 
b. Pithecanthropus dubius von K.

This mandible is only a fragment of the right portion with the first and second molar in situ; the root of the second premolar, of which the crown is broken off, still remains in the bone. The fragment was found near Sangiran by von Koenigswald in 1939, and according to the collector, it came from the Putjangan Beds. The dimensions of the jaw fall slightly below the minimum of the gorilla. It is thicker than that of Pithecanthropus B., but thinner than that of Meganthropus. There is a gradual reduction in thickness from the torus superior, where it amounts to $19.0 \mathrm{~mm}$., to the torus inferior, where the thickness is $13.5 \mathrm{~mm}$. This feature is decidedly simian and just the reverse of the hominids. But the large mental foramen consists of a single aperture located half-way in the height of the mandible in line with the second premolar, as is usual in the hominids, including Meganthropus and Pithecanthropus.

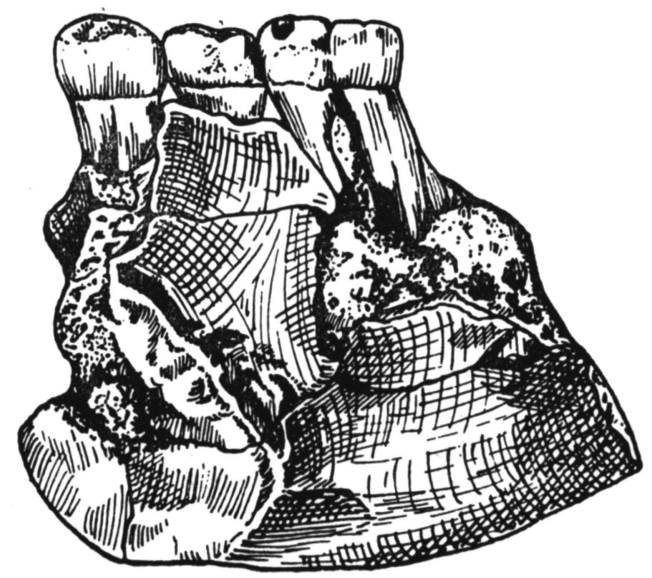

Fig. 3.

babilities seem to be against such a conclusion, and (it must be emphasized again) there is at present no really convincing morphological basis for the recognition of more than one species, Pithecanthropus erectus".

Weidenreich who was the first to speak of Giant Man on Java is contradicted by Le Gros Clark in the following way: "Some authorities have interpreted the large mandibular fragments from Sangiran as evidence for the existence on Java during the Pleistocene of giant hominids. This seems to be a misapplication of the term giant, which is commonly taken to refer to stature. But a large hominid jaw does not imply a giant individual. On the contrary, so far as other palaeontological evidence goes, there is some reason for assuming a negative correlation between the size of the mandible and the total stature". 
The dentition is arranged in the shape of a horseshoe, another characteristic of the hominids. But the unusually large molars exhibit a decrease in size from front to back, a feature common in the anthropoids. Furthermore the pattern of the dentition points to specialization. The first molar is badly worn, exposing the dental cavity. Its crown is almost square, measuring $13.0 \mathrm{~mm}$. in length and breadth. The second molar is less worn and measures $14.1 \mathrm{~mm}$. in length and 14.3 $\mathrm{mm}$. in breadth. The jaw exhibits no vestige of a mental spine. The symphysis is different from Meganthropus. Von Koenigswald does not rule out the possibility that the mandible is that of an anthropoid not yet known, in which a number of hominid characteristics are combined. The hominid nature is not yet determined. Supplementary finds are highly desirable and may enable us to delete Pithecanthropus dubius from the list of the early hominids. 25

\section{c. Pithecanthropus B.}

The Pithecanthropus mandible B (Fig. 4) was also found by von Koenigswald's collectors in 1936. It came from the black clay at Bukuran, near Sangiran. The fragment presents the right side of a heavy mandible, measuring $86.5 \mathrm{~mm}$. in length. The ascending ramus is completely missing. The second premolar and the three molars are still in situ, the alveolae of the canine, the lateral incisor and the first premolar are

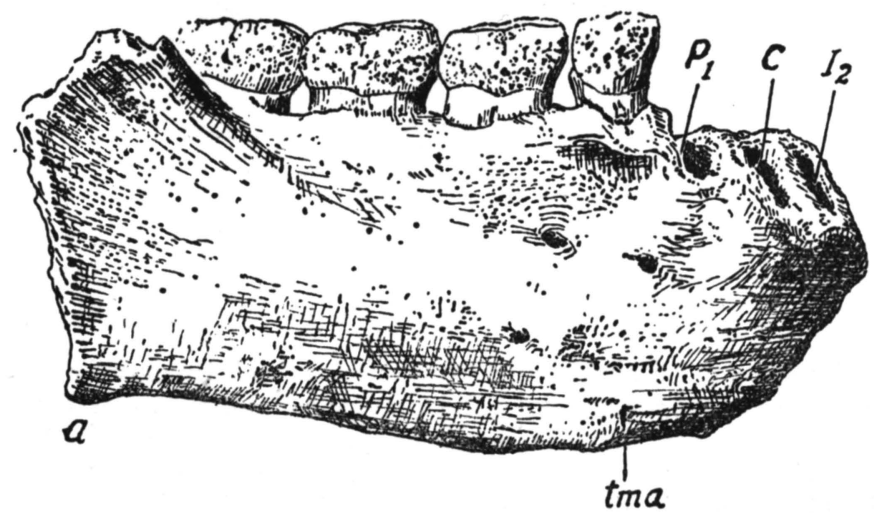

Fig. 4.

25 Von Koenigswald: in van Bemmelen; '49, 107. 
preserved. The alveolus of the incisor must have been relatively small. The size of the molars, still present, increases from front to back. The second premolar, therefore, is exceptionally large, measuring $9.2 \mathrm{~mm}$. in length, and $11.0 \mathrm{~mm}$. in breadth. The first molar is the smallest. The jaw has no interior torus transversus, its place being marked by a slight protuberance. Besides, the mandible exhibits three mental foramina, two (the largest) at a higher level than the third, which is a rare feature in hominids. The first and second molar are more or less quadrangular, both having five cusps. The third molar is oval-shaped and has six cusps. The first premolar exceeds the maximum values of modern man in regard to length and breadth and closely approaches the measurements of Pithecanthropus pekinensis. The measurements of the three molars as compared with those of Pithecanthropus pekinensis are as follows:

Lower teeth Pithecanthr. B Pithecanthr. pekin.

$\begin{array}{lll}\text { Length of } \mathrm{M}_{1} & 12.5 \mathrm{~mm} . & \text { average } \\ \text { Length of } \mathrm{M}_{2} & 13.0 \mathrm{~mm} . & 12.6 \mathrm{~mm} . \\ \text { Length of } \mathrm{M}_{3} & 14.5 \mathrm{~mm} . & ?\end{array}$

$\begin{array}{lll}\text { Breadth of } \mathrm{M}_{1} & 13.0 \mathrm{~mm} . & 11.8 \mathrm{~mm} . \\ \text { Breadth of } \mathbf{M}_{2} & 13.2 \mathrm{~mm} . & 12.5 \mathrm{~mm} . \\ \text { Breadth of } \mathbf{M}_{3} & 12.5 \mathrm{~mm} . & ?\end{array}$

This large and massive mandible fragment and the maxilla of Pithecanthropus modjokertensis, fit well together. 26

d. Pithecanthropus modjokertensis von K.

In 1939 von Koenigswald's men found some large cranial fragments of a gigantic early hominid in the Putjangan Beds, near Sangiran. The finds include the posterior half of a brain case and the lower portion of a maxilla. The former fragment consists of almost the entire plate and the floors of the nasal cavity. The teeth, except for the four incisors, of which the alveolae are preserved, and the second and third left molar, are in situ. An isolated shovel-shaped upper-incisor was also found.

28 Von Koenigswald; '40, 140-65. Weidenreich; '44, 56-62. 
According to Weidenreich,27 the skull had been crushed with great force in prehistoric times, causing a dislocation of the component parts. He has examined and studied the casts and was able to reconstruct the whole skull by readjusting the fragments and taking the mandibles of Pithecanthropus $\mathrm{B}$, and Pithecanthropus pekinensis $\mathrm{G}_{1}$ as models.

The size of the skull exceeds that of the Middle Pleistocene Pithecanthropus erectus to such an extent that its difference cannot be explained as a difference in sex. We may assume that this skull represents a new species of the Pithecanthropus group of gigantic size, and more primitive in several respects. Weidenreich proposed the name Pithecanthropus robustus, but this has been discarded by von Koenigswald and renamed Pithecanthropus modjokertensis or Pithecanthropus IV.28 It is not impossible that Pithecanthropus modjokertensis is a direct descendant of the still larger Meganthropus. The skull is not only longer, but conspiciously broader than that of Pithecanthropus I and II. In his comparative studies, Weidenreich has made use especially of Pithecanthropus II as it is more complete than the holotype found by Dubois.

The greatest cranial length is $150 \mathrm{~mm}$. and of Pithecanthropus II $136 \mathrm{~mm}$; the greatest cranial breadth of the present specimen, which is at the base $158 \mathrm{~mm}$. as against $135 \mathrm{~mm}$. in Pithecanthropus II. The skull-vault is remarkably low, especially in the occipital region and the obelion. The nuchal plane is very flat. The occipital curvature exhibits an angle of $91^{\circ}$; in Pithecanthropus II the angle is $103^{\circ}$, in Homo $^{\circ}$ soloensis $91^{\circ}$; in the Rhodesia skull $99^{\circ}$. The skull possesses a peculiar sagittal crest which consists of a series of knob-like protuberances, and terminates on either side in rather protruding supra-orbital ridges. This structure has not been found in the other Pithecanthropus skulls or in the anthropoids. The mastoid process is large, projecting downwards and sharply inwards, while it is an insignificant protuberance in Pithecanthropus II.

The most interesting feature of the skull is its extraordinary broad maxilla, which unfortunately could not be compared with that of other Pithecanthropoids, since they are all missing. But it must have been a powerful maxilla, provided with thickened areas, and agreeing well with the mandible of Pithecanthropus B.

The palate, which is smooth and does not show ridges or furrows, is peculiar. Its length amounts to $75 \mathrm{~mm}$., as against $57.7 \mathrm{~mm}$. in the

27 Weidenreich; '44, 17-32. Von Koenigswald: in van Bemmelen; '49, 107-10.

28 Von Koenigswald: in van Bemmelen; '49, 107-10. 
Rhodesian skull. The teeth possess human characteristics, their pattern being quite similar to those of Pithecanthropus pekinensis, except that in the latter the cingulum is more strongly developed. The canines are small compared with those of the anthropoids; nevertheless they are considerably larger than is found in any other fossil or recent man, and only the largest Pithecanthropus pekinensis canine equals them in size. The breadth exceeds the length, as is the case in all human canines, while in the anthropoids it is just the opposite. The canines are slightly higher than the premolars. The second molar is by far the largest of the three, the third the smallest. This, too, is an anthropoid feature. Between the lateral incisor and the canine is a wide interstice (diastema) of $6.2 \mathrm{~mm}$.

Below are given the measures of the teeth as taken from the casts made by Weidenreich:

\begin{tabular}{ccc} 
Teeth & Length & Breadth \\
\hline $\mathrm{I}_{2} \mathrm{r}$ & $10.0 \mathrm{~mm}$. & $10.4 \mathrm{~mm}$. \\
$\mathrm{C} \mathrm{r}$ & 9.5 & 11.7 \\
$\mathrm{C} \mathrm{r}$ & 9.5 & 11.9 \\
$\mathrm{P}_{1} \mathrm{r}$ & 8.2 & 12.4 \\
$\mathrm{P}_{1} \mathrm{l}$ & 8.5 & 12.4 \\
$\mathrm{P}_{2} \mathrm{r}$ & 8.2 & 12.1 \\
$\mathrm{P}_{2} \mathrm{l}$ & 8.5 & 12.3 \\
$\mathrm{M}_{1} \mathrm{r}$ & 12.1 & 13.7 \\
$\mathrm{M}_{1} \mathrm{l}$ & 12.3 & 13.6 \\
$\mathrm{M}_{2} \mathrm{r}$ & 13.6 & 15.2 \\
$\mathrm{M}_{3} \mathrm{r}$ & 10.8 & 14.0 \\
\hline
\end{tabular}

The dentition combines human and anthropoid characteristics. The lower jaw has no simian shelf. Undoubtedly the skull is the largest and most massive of any known hominid. But in Meganthropus which is only represented by a fragment of the lower jaw, this feature was presumably even more gigantic. There is a close relationship with Pithecanthropus I and II of the Middle Pleistocene, but Pithecanthropus IV is not only larger and more primitive, but also relatively lower. Contrary to these characteristics is the central position of the occipit which is about the same as in modern man. ${ }^{29}$ Von Koenigswald's examination of the original has not yet been finished.

20 Weidenreich; '44, 17-32. 
e. Homo modjokertensis von $\mathbf{K}$.

This skull is that of an infant (Pl. 6) and it was excavated, as was previously stated, by employees of the Geological Survey in the Putjangan Beds near Modjokerto in 1936. It belongs to a child about 3 years old, as the fontanels were already closed. The skull was provisionally classified by von Koenigswald under the name of Homo modjokertensis. It is difficult to compare with adult examples, since it is not fully grown, and important changes take place at a later age. The bone structure is very fragile. The skull has a distinct vaulted forehead, which gives it a very human appearance. It has no supra-orbital ridges. On the other hand, it possesses certain primitive characteristics, such as the post-orbital constriction, the rather low vault, and the occipital curvature. The length of the skull is $138 \mathrm{~mm}$., the breadth $109 \mathrm{~mm}$., and the length-breadth index is 78.9 .

A. J. P. van den Broek compared a cast of the skull with that of a child of the same age of the Pesechem tribe in New Guinea and considered the possibility that the fossil skull, when fully developed, would not differ from that of modern man.

Von Koenigswald inclines to a quite different opinion. He assumes the possibility that the skull belonged to a member of the Pithecanthropus group, most probably to Pithecanthropus modjokertensis, despite the existence of great morphological differences. This interpretation can be understood only in the light of L. Bolk's foetalisation theory. 30 The main point of this theory is based on Bolk's examination of a dead pregnant chimpanzee. He noticed that the foetus was more human than a full-grown specimen. The skin was hairless, except on the skull. The snout was less protruding and the skull clearly exhibited a bulge of the forehead. The foramen magnum was located as in the skull of modern man. The foetal stage in man remains the same along broad lines, but in the anthropoid after it has left the womb a process takes place during growth which results in the gradual recession of the forehead. The foramen magnum faces more to the front. Bolk wanted to show that the external factors and natural circumstances have no connection whatsoever with the development of the specific human forehead, but that it is rooted in the organism of the creature: in the ape as in man. The progress of growth in man is more conservative, in the ape more propulsive. Man in his foetal stage is not bound to pass a simian stage; rather it seems that the simian foetus passes a human stage. This human

30 Bolk; '26. 
stage, however, is of a temporary nature. Von Koenigswald thinks that the process of growth in an early hominid took place in the same way as in the ape in many respects. Hence Pithecanthropus probably was born with a more or less vaulted forehead, a feature still to be seen in the first years of his life, while the recession of the forehead would take place only at a later age.

In view of the very early geological age of the skull, von Koenigswald's conclusion seems the more acceptable, in spite of the great anatomical discrepancies. 31

31 Von Koenigswald; '36c, 149—57. '40, 116 20. 


\title{
I. PALAEOLITHIC
}

\begin{abstract}
"We can now form a picture of Pithecanthropus as a man rather short in stature by modern standards, with limbs fashioned as they are to-day, but with beetling brows, sloping fore-head, powerful jaws equiped with rather large teeth and strongly developed neck muscles. It may also be presumed on account of the rather small size of brain, that he had a relatively low standard of intelligence. Nevertheless, he was definitely human; indeed, it may be said that all the recent discoveries have served the hominid rather than the anthropoid ape characters of Pithecanthropus".
\end{abstract}

Le Gros Clark.

\section{THE MIDDLE PLEISTOCENE}

A. The Kabuh Beds.

Everywhere in Java the Kabuh Beds are of nearly the same composition. They consist of water-deposited sediments of volcanic origin such as tuffs, sandstone and conglomerates. At Sangiran, especially at the section exposed by the Tjemoro River near the village of Bapang, the entire series from the marine Lower Pliocene to the Uppermost Pleistocene is tabulated. (Fig. 5; Pl. 2, 3).

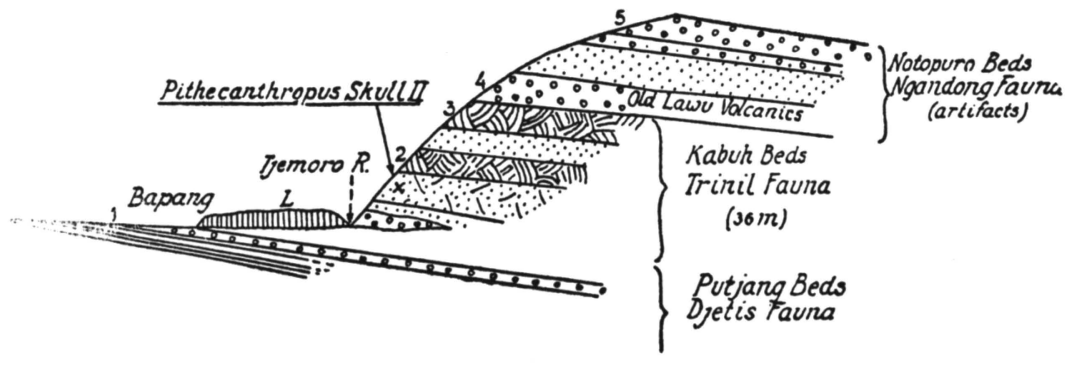

Fig. 5.

After Van Bemmelen and de Terma

The Kabuh Beds, 15 to $50 \mathrm{~m}$. thick which overlie the Putjangan Beds, consist mainly of light gray-green tuffs, sandstone and conglomerates, and represent a fluvial deposit. At the base lies a strongly cemented 
basal deposit ( $1 \mathrm{~m}$. thick), poor in fresh-water molluscs, but rich in fossil vertebrates which are most numerous in the sandstone tuffs. In this layer the skull cap of Pithecanthropus II was found. The Bapang formation corresponds with the Trinil mud-flow agglomerates, which are also of Middle Pleistocene age. Next follow tuffaceous sands and conglomerates with fossil plant remains $(9 \mathrm{~m}$. thick). At the base of this layer, near Tandjung, the skull fragments of Pithecanthropus III were found, whilst north of Ngebung it yielded a wealth of palaeolithic flake tools of chalcedony in the upper portion of the layer. But there is a disagreement concerning the boundary between the Middle- and the Upper Pleistocene at this locality.

Anyway, the flake tools did not come from the same beds as those containing Pithecanthropus but from a layer somewhat higher in the sequence.

Trinil is the village which attained fame as the result of the discovery of the much discussed skull cap of Pithecanthropus I. Therefore, its geology has been carefully examined by several scientists including Dubois (1891_-'92), Carthaus and Dozy (1911), van Es (1931) and Duyfjes (1936). The lowermost deposits of sandstone and tuffs of the Trinil Beds (Fig. 6) have been discussed in the preceding paragraph. They are overlain by Middle Pleistocene Kabuh Beds which are composed of the following:

a. tuffs, pumice, lapilli and large andesite blocks;

b. the main bone-bed between $40 \mathrm{~cm}$. and $1 \mathrm{~m}$. thick, developed under fluvial conditions; the bones are much waterworn. Entire skeletons are absent; they went to pieces before being deposited in this layer;

c. a thin clay layer (60 to $80 \mathrm{~cm}$. thick) containing fossil leaves, roots and fruits;

d. a white-gray sandstone, representing a fluvial deposit, with volcanic components, fossil bones of the Trinil fauna and fresh-water molluscs;

e. tuffaceous sandstone and conglomerates (from 3 to $6 \mathrm{~m}$. thick), bearing traces of the Trinil fauna. (Fig. 6).

Not so distinct is the formation of the Gunung Butak which is entirely covered by teak-wood. Near Kedung Brubus, $45 \mathrm{~km}$. east of Trinil a small fragment of a human mandible, as well as a tibia of Pithecanthropus were found. Here, too, fluvial deposits seem to overlie the Putjangan Beds, consisting of sandstone, tuffs and conglomerates, which 


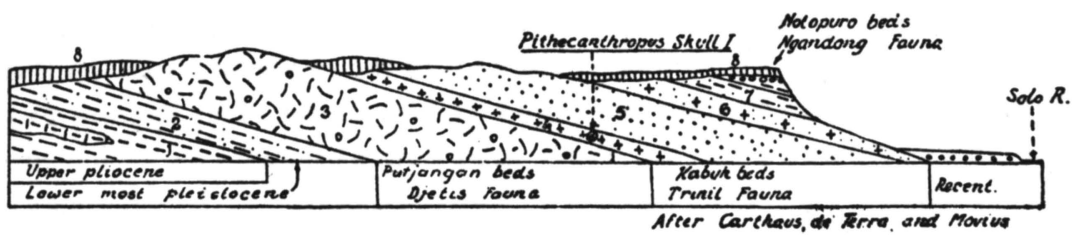

Fig. 6.

apparently correspond with the mud-flow conglomerates of Trinil. The Kabuh Beds are folded and dip approximately $40^{\circ}$ to the southwest.32

\section{B. The Trinil fauna.}

The Kabuh Beds at Sangiran, especially their conglomerate banks, contain a rich Middle Pleistocene fauna, which also includes the skull cap of Pithecanthropus II (near Bapang), as well as the fragments of the skull cap of Pithecanthropus III found in a slightly younger tuff near Tandjung. Apart from these early human remains, there occur such distinct elements as Stegodon trigonocephalus Martin, Elephas cf namadicus Falc., Cervus (Axis) lydekkeri Martin, Bos (Bibos) palaeosondaicus Dubois, and Duboisia kroesenii.

The Trinil fauna was also found in the fluvial beds of the Butak Hills and between Tegal and Cheribon. Von Koenigswald refers to it as a Sino-Malayan fauna on the basis of the presence of Simia, the Malayan bear, tapir, rhinoceros and Stegodon. De Terra claims, however, that Simia has been found, too, in India.33 The Trinil fossil bones are heavily fossilized and dark-coloured. Their weight is $35 \%$ more than fresh material. The complete list of the Middle Pleistocene Trinil fauna is as follows:

\section{PRIMATES:}

Pithecanthropus erectus Dubois, Simia satyrus L., Symphalangus syndactylus Desm., Hylobates leuciscus Geoffr., Pithecus pyrrhus Horsf., Macaca irus Cuv., Macaca sp.

\section{PROBOSCIDEA :}

Stegodon trigonocephalus M., Elephas ex. aff. namadicus Falc. Cryptomastodon martini v. $\mathbf{K}$.

32 de Terra; '43b, 456-57. Von Koenigswald; '40, 39-43. Van Es; '31.

33 Von Koenigswald; ' $40,41-43$. 


\section{UNGALATA:}

Rhinoceros sondaicus Desm., Rhinoceros kendengensis, Tapirus cf. indicus Desm., Tapirus cf. augustus M. et G., Sus macrognathus Dub., Sus brachygnathus Dub., Hippopatamus namadicus Falc., Cervus (Axis) lydekkeri Martin, Cervus (Rusa) cf. hippelaphus Cuv., Muntiacus muntjak kendengensis Str., Tragulus kanchil Raffl., Duboisia kroesenii Str., Bos (Bibos) banteng palaeosondaicus Dub., Bos (Bubalus) bubalis palaeokerabau Dub., Bos (Bubalus) sp.

\section{CARNIVORA:}

Felis palaeojavanica Str., Felis tigris L., Felis pardus L., Felis bengalensis Kerr., Paradoxurus hermaphroditus Pall., Arctictis binturong Raffl., Viverricula malaccensis Gml., Viverra div. spec., Mececyon trinilensis Str., Cuon sangiranensis, Ursus malayanus Raffl., Lutra cf. cinerea, Lutra cf. sumatrana G.

\section{INSEGTIVORA:}

\section{Echinosorex sp.}

\section{RODENTIA:}

Lepus nigricollis Cuv., Lepus sp., Acanthion brachyrus, Hystrix sp., Rhizomys cf. sumatrensis Raffl., Rattus sp.

\section{The Pithecanthropoids.}

a. Pithecanthropus A.

On November 24th 1890, Eugène Dubois reported among the fossil mammalian fauna from a sandstone and andesite tuff near Kedung Brubus, a fragment of a human mandible contemporary with Stegodon, Elephas, Hippopotamus and Hyaena in Java. It was the first human fossil to be found in Java. The fragment in question consists of a small triangular piece of the right lower jaw. It is only $36 \mathrm{~mm}$. long. The alveolae of the canine and of both premolars are preserved. Portions of the roots are still preserved in the alveolae. On the outer surface the tuberculum marginale anterius is visible. Compared with Pithecanthropus mandible B., the jaw is low, whilst the measurements of its alveolae indicate a smaller dentition. Its height measured at the interstice between the canine and the lateral premolar is $28.3 \mathrm{~mm}$., (Pithecanthropus B.: $33.0 \mathrm{~mm}$.; Pithecanthropus pekinensis A II: $27.8 \mathrm{~mm}$.; Pithecanthropus pekinensis G I: $33.4 \mathrm{~mm}$.) ; the thickness at the same level is $16.8 \mathrm{~mm}$. 
(Pithecanthropus B: $16.9 \mathrm{~mm}$.; Pithecanthropus pekinensis A II: 14.5 $\mathrm{mm}$.; Pithecanthropus pekinensis G I: $16.3 \mathrm{~mm}$.). In other respects this small fragment is difficult to use for comparative study. Von Koenigswald regards the mandible as belonging to a female Pithecanthropus. ${ }^{34}$

\section{b. Pithecanthropus erectus Dubois (Pithecanthropus I).}

In the autumn of 1891, Dubois discovered a tooth of an anthropoid and a peculiar skull cap at Trinil. At first, he regarded the skull cap as the remains of an individual which he named Anthropopithecus, considering the relatively large skull too big for an ape, and pointing to the absence of bone ridges on the skull. Exactly a year later, a left femur was collected from the same level, about 15 metres up-stream from the above-mentioned locality. He assigned it to the same individual and concluded that it could walk erect like a man, since the femur does not differ in any fundamental respect from that of modern man. Dubois considered this creature to be an intermediate form between ape and man, and thought it highly probable that man had developed from this type. In 1894 Dubois changed its name into Pithecanthropus, a name which as early as 1868 had been given by Haeckel to a hypothetical being that was supposed to have lived in the Tropics, could walk upright and possessed a higher mental development than the anthropoids, although it could not speak. For this species Dubois added the designation 'erectus' to it, the complete name then being Pithecanthropus erectus. By this discovery Dubois found the actual object of his search and fulfilled the purpose of his going to Indonesia. He had demonstrated the validity of Haeckel's hypothesis. ${ }^{35}$

Dubois spent most of his remaining life in the study of these highly important, although incomplete, discoveries. Of course, he changed his mind more than once in the course of the years. The same applies to the geological age of the finds. Since this discovery, many scientists have occupied themselves with the Pithecanthropus problem; seldom have finds such as those from Trinil attracted so much attention. According to Quenstedt, the bibliography on this subject alone amounted to more than 500 scientific publications in 1936, and ever since many important papers, arnong which the monographs by von Koenigswald and Weidenreich and Le Gros Clark, have been published.

In 1896 Dubois collected the opinions of 19 authorities, five of whom

34 Dubois; '24, 265-78, 459-64.

35 Dubois: 1894 . Von Koenigswald; '43, 152-57. 
regarded the skull cap as that of an ape, seven believed it to be human, and seven others considered it as an intermediate type between ape and man. Later opinions varied from a degenerated Homo sapiens, a pygmy, a small Neanderthalian, to a bastard of ape and man. ${ }^{36}$ The Trinil discovery stood alone for a long time. Expeditions were sent out, but no new Pithecanthropus discoveries were forthcoming. The Selenka expedition of $1907-08$ returned with a wealth of fossil vertebrates, but no additional Pithecanthropus finds. The Sonde tooth which was assigned by some to this species, is in fact one of modern man. The excavations in 1930-31 produced no results. But finally as the result of the discoveries of Pithecanthropus pekinensis (also named Sinanthropus pekinensis) in North China by Davidson Black, followed by those by von Koenigswald in Java in 1936-38, this creature was released from its isolation. Thus we have achieved a far clearer conception of the species, anatomically as well as geologically, and its human nature can no longer be denied.

The holotype, or Pithecanthropus I, consists of a very thick and heavy skull cap, complete above the ears and eyes. The exterior parts are smooth and possess no crests like in gorilla and orang-utan. For the rest, its shape especially in side view is rather simian, an impression caused mainly by the markedly receding forehead and the heavy supraorbital ridges. The skull is very low, the highest point is exactly at bregma as in the anthropoids. Its greatest length is $184 \mathrm{~mm}$; greatest breadth $134 \mathrm{~mm}$. The length-breadth index is 72.8 . Thus the skull is decidedly dolichocephalic. The minimum breadth of the forehead is merely $84 \mathrm{~mm}$. The cerebral volume is $914 \mathrm{cucm}$. (Homo sapiens 1200 to 1500 cucm.). With respect to this feature Pithecanthropus occupies an intermediate position between man and anthropoid. Due to the position of the foramen magnum, the head was carried in a primitive and forward position. Endocranial casts show that the frontal lobes are smaller than in modern man, but larger than in the biggest existent anthropoid. The left frontal lobe is slightly larger than the right one. The parietal lobes are strongly developed, but are exceeded by those in recent man. The occipital lobes are intermediate between man and ape. 37 The question whether Pithecanthropus had the power of speech is still a much discussed problem.

The left femur, found in the same bone-bed about 15 metres up-

38 For a complete summary, see: Von Koenigswald; '40, 15-24.

37 Bouman; '39, 1-3. Ariëns Kappers and Bouman; '39, 30-40. 
stream from the skull cap, is remarkably straight and does not resemble that of an anthropoid; the anatomical features prove the habit of an upright gait. From this it was deduced that in this species limbs of human type must have developed before the appearance of a truly human form of skull and brain. Afterwards, five more femora have been discovered in Trinil and in Kedung Brubus. The teeth, which Dubois attributed to Pithecanthropus, later proved to be those of a fossil orang-utan. The geological age can be established with reasonable certainty as Middle Pleistocene.

\section{c. Pithecanthropus II.}

It was 46 years later that the second Pithecanthropus skull cap was found. One of von Koenigswald's collectors found it in 1937, but unfortunately he did not appreciate its value for he smashed it into 30 pieces in order to get compensated for each separate fragment. The skull had been recovered from a sandstone rock-fall on the right bank of the Tjemoro River near the village of Bapang, Sangiran. A closer examination of the spot proved that the rock had fallen from a cliff $5 \mathrm{~m}$. above the river. Von Koenigswald in Bandung succeeded in restoring the specimen, since the fresh fractures fitted well together. (Pl. 1a, b). After the restoration it appeared that the skull was more complete than Dubois' holotype. Part of its base with the region of the condyles and the temporal bones of both sides are preserved. The skull is slightly lower and broader, but for the rest it is exactly like Dubois' specimen. The endocranial cast, examined by Ariëns Kappers and Bouman, also showed a great resemblance to the holotype. The bone structure, on the other hand, is thicker. The mastoid process is only a small protuberance. The greatest length is $176.5 \mathrm{~mm}$., the breadth $140.0 \mathrm{~mm}$. and the lengthbreadth index is 79.2 ; the cerebral capacity is only $835 \mathrm{cucm}$. The skull shows the same supra-orbital ridges which are separated from the cap by a weak depression. The forehead slopes sharply backwards. Only the left part of the ridges is present. The sutures are closed which points to a grown-up individual. The smaller measurements are attributed to sexual differences, since it is probable that the skull is that of a female, the Trinil example that of a man. Generally considered this skull looks more human due to its greater completeness than Dubois' holotype.98

38 Von Koenigswald; '40, 78-116. Bergman and Karsten; '52. The Fluorine test has shown that the femora and skull cap of Pithecanthropus and the Trinil fauna are all contemporary. 
d. Pithecanthropus III.

In 1938 von Koenigswald's collectors found some strongly weathered fragments of a third skull, which left no doubt that they belonged to the same type as the skulls I and II. The fragments came from a high hill behind the village of Tandjung in the southern part of the Sangiran dome.

The find consisted of an almost completely preserved right parietal bone, the upper third of the left parietal, and the greater portion of the upper part of the occipital bone. As the cranial sutures are wide open, the skull represents a young individual. It was possible to calculate the position of lambda and opisthocranion, and on this basis to reconstruct the mid-sagittal region. They do not differ essentially from Pithecanthropus II. The skull's length is estimated at $177 \mathrm{~mm}$., and its breadth probably was lesser than that of skull II. The bones are extraordinary thick for a young individual. Its incompleteness did not allow any further conclusions. 39

\section{The Lower Palaeolithic Cultures.}

a. J a va.

It is clear that Java was inhahited by men since the later part of the Lower Pleistocene. But the oldest palaeolithic artifacts so far found can be placed in the late Middle Pleistocene at the earliest.

In October 1935, Dr G. H. R. von Koenigswald 40 and Mr. M. W. F. Tweedie, Curator of the Raffles Museum at Singapore, paid a visit to the Sewu Mountains, a typical Cone-Karst region composed of an uplifted and compact massif of Upper Miocene reef-limestone overlaying folded Lower Miocene volcanic beds. On the 4th of October they discovered for the first time on Java, a series of large, massive, crudely worked stone tools, apparently of a Lower Palaeolithic character. The vast majority of the tools were manufactured of silicified tuff and are dark in colour. Other examples were shaped out of silicified limestone and a few were made of fossil wood. The implements were picked up in a dry watercourse of the bed of the Baksoka River, south of Punung. But similar tools were collected in a 'boulder conglomerate' in the bank of the river, 3-4 metres above its bed. In some places this bank dipped under the level of the floor of the valley, showing that it was gently folded. According to von Koenigswald this proves that the tectonics

39 Von Koenigswald; '40, 102-10.

40 Von Koenigswald; '36b, 52-60. '36c, 149-57. 
of the implementiferous conglomerate were not younger than the Middle Pleistocene. Yet von Koenigswald was not quite sure if these were the parent layers of all tools; some of them may have been secondarily deposited and washed out from higher horizons. Von Koenigswald stated typologically as well as geologically, that the newly discovered Palaeolithic culture represents a 'complete Chellean' with hand-axes, flake-tools and a few crude blades. In total approximately 3000 stone tools were collected in this very prolific locality. But thus far none have been extracted from a datable geologic horizon and palaeontologic evidence was absent.

In the spring of 1938, after having finished a fieldprogram in the Irrawaddy Valley of Upper Burma, which resulted in the acknowledgement of a peculiar Lower Palaeolithic cultural development in Southern and Eastern Asia, ${ }^{41}$ Hellmut de Terra, Père Teilhard de Chardin and Hallam L. Movius Jr. accompanied von Koenigswald to the Baksoka area to study the situation on the spot, and the geologic problems connected with it.42 P. Teilhard de Chardin only devoted a few pages to the problem. ${ }^{43} \mathrm{He}$ observed three levels of implementiferous terraces on respectively 2 metres (composed mainly of silt), on 10 metres (red gravel and loam with a basal layer of coarse gravel) and on 25 metres (boulder gravel with red loam). Teilhard also qualifies the Palaeolithic assemblage as 'Chellean', in which the flake-tools are hardly typical.

The best study of the Patjitan tools is that of Hallam L. Movius Jr. $44 \mathrm{He}$ contests their Chellean character, pointing out that true bifaces are rare, only $153(6.32 \%)$ out of 2419 tools being classified as handaxes, of which only 42 examples were completely worked around the butt-end. The working technique in most cases, especially the longitudinal flaking parallel to the axis of the tool, is in the chopper tradition. More than $50 \%$ of the assemblage is formed of flake-tools and trimming flakes showing signs of use. The massive tools made on pebbles or on large flakes and sphere-segments derived from a shattering process, consist of choppers, chopping-tools, hand-adzes and proto-hand-axes. Therefore, the Patjitanian shows a striking difference and is in marked contrast with the Lower Palaeolithic bifaces of Peninsular India, the Near East, Europe and Africa. It forms part of the great Chopper/Chopping-tool Complex of the Far East which represents a continuum of an archaic

\footnotetext{
Movius; '43, 341-439. ' $45,1-125$.

de Terra; ' $43 \mathrm{~b}, 457-59$.

3 Teilhard; '37b, 23-33. '38, 449-56.

Movius; '44, 79-94. '48, 352-64.
} 
pebble-culture, uninfluenced by contemporary innovations and resembling such pebble-cultures as the African Oldowan and Pre-Stellenbosch it is named the Soanian, in Burma 46 (the Anyathian), in Siam 47 (the industries. Thus far this complex has been recorded in Punjab 45 where Fingnoian), in Malaya 48 (the Tampanian) and in Northern China 49 where it is termed the Choukoutienian and where it is found in association with skeletal remains of Pithecanthropus pekinensis. In some instances, like in the Soanian, Anyathian and the Choukoutienian a Middle Pleistocene antiquity could be established. The Anyathian, the Fingnoian and the Choukoutienian are devoid of hand-axes. Several authorities when referring to the Chopper/Chopping-tool Complex of the Far East

45 de Terra and Patterson; '39, $1-354$.

46 Movius; '43, 341-439. de Terra; '43a, 271-339.

47 Van Heekeren; '47, 24-32. Teilhard; '51, 547-49.

48 Collings; '38, 575.

49 Movius; '49b, 386-402. While Movius has discovered an unrecognized Lower Palaeolithic culture in the Far East, the classic sequence established in Western Europe is not applicable. It was found necessary to invent new archaeological terms for the large, massive pebble-tools in the following way: "In dealing with the archaeological material from Burma and Java, it was found necessary at the outset to establish two new classes of implements chopping-tools and hand-adzes - and to redefine the terms chopper and scraper. This simply provides a convenient method of arranging the material for purposes of description. Each is a purely artificial category of little or no significance from the point of view of function, which, with respect to such a remote period (Middle Pleistocene), is still a question of speculation. Actually, the only difference between a chopper and a scraper is one of size, and in this sense large, crude scrapers are called choppers. The latter are usually core tools, whereas flakes predominate in the scraper category. A chopping-tool, on the other hand, is a core implement, of ten made on a pebble, with a cutting-edge worked from both sides. In many cases the edge itself has been fashioned by alternative flaking, which produces a tool remarkable for its sinuosity. Hand-adzes are roughly tabular chopping or cutting implements, which resemble choppers, except for the fact that they are square or rectangular, rather than of round or oval outline. Choppers, chopping-tools and hand-adzes all differ fundamentally from the classic hand-axe or coup-depoing, which is a true bifacial tool extensively flaked on both upper and lower surfaces. Whenever the above types of implements are found, that is in Punjab, Northern China, Upper Burma and Java, the definitions given here will be adhered to for purposes of comparison". In later papers, Movius has added another type to the above-mentioned terms i.e. Proto-hand-axes: "Implements, in most cases made on flakes, that are worked on the upper surface only, into crude and roughly pointed types of hand-axes of planoconvex section. Cortex normally adheres to the butt-ends, and seldom is the upper surface flaked all over. These tools may be considered as transitional between hand-adzes and true hand-axes - bifaces or coup-de-poings - from a typical point of view. In general, no absolutely rigid line can be drawn between the above classes of implements in all cases". 
consider the racial factor to be essential, its authors being members of the Pithecanthropus group of mankind.

In the descriptions of our own finds in the Baksoka area and the newly discovered Tabuhan sites, we have accepted Movius' terminology, but we have redefined the choppers into four distinct types: 'Flat-iron' types (long, high-backed, plano-convex in section, flat-iron shaped, with resolved longitudinal trimming; some examples are keeled). Side-choppers (massive side-scrapers, irregular in outline). Cleavers (large flakecleavers; according to Movius they are not like the cleavers which play such a prominent role in the late Madrasian of Central and Southern India. They are quite different and seem to be manufactured by an entirely different technique). .50

'Flat-iron' choppers and 'Tortoise' choppers are very characteristic for the Patjitanian and may be used as type-specimens or as guide-forms for this industry. 51

On the 22nd of October 1952, Mr. A. Christie of the School of Oriental and African Studies, London, and the present writer made a brief trip to the Baksoka Valley. Stone tools were collected, but the soil was so moist and swampy that it was hard to move around. On the 6th of August the same area was visited again. This time I was accompanied by Dr P. Marks, Mr. Soejono and Mr. Basoeki. We noticed an implementiferous boulder bed on the right bank of the river and 3.20 metres above it. The tools were rolled and were found in the upper part of the bank. Similar tools were picked up in the rivergravel and were found on low banks ( $1 / 2-1$ metre) of the Ngambar tributary. On the 7th of August, while searching for a fossil-containing fissure near Tabuhan, Mr. Soejono discovered a well-finished 'Flat-iron' chopper near the Gedeh River. It was the first Patjitan tool ever to be found in the area and it led to a more careful examination of the surroundings and to the organization of more investigations. Under a rock-fall near the Gedeh River which site was filled up by young black clay and silt (the site is overflown when torrents come down), more typical Patjitan tools were found. In the riverbed, too, a number of palaeoliths were collected and on the right bank we located a small boulder bed with stone tools in the upper part, one metre above the river. More stone tools were collected in the dry watercourse of the Serikan River, which connects the Gedeh River with the Sunglon River. A few implements were extracted from a low half a

50 In a letter from Movius to the present writer, dated July 25, 1956.

51 Van Heekeren; 1955, 1-12. 
metre above the stream level) boulder bed. New investigations were planned in October 1953, but the present writer fell ill. My co-operators Mr. Soejono and Mr. Basoeki carried on further research during a ten-day stay. The Tabuhan area was mapped and a trial excavation was performed in the Songterus Cave, resulting in the discovery of mesolithic tools and neolithic implements made of stone, bone and shell and of a sub-fossil fauna including teeth of Elephas maximus. Some new palaeolithic sites were discovered on the right bank of the Sunglon River; a small cemented implementiferous boulder bed, one metre above the river and at Kiut a terrace containing Patjitan tools 5.9 metres above the river. A few palaeoliths were collected on the left bank, 20-23 metres above stream level at a site which may be the remnants of a heavily dissected terrace. In December 1953, we spent another ten days in the Sewu Mountains, mainly making reconnoitring trips. The soil near the rivers was very swampy at this time of the year. Nevertheless, we collected quite a number of palaeoliths; among these two beautiful hand-axes, one round in outline and one almond-shaped. They recall in general form as well as in detail some standard forms of the Eurafrican Acheulean. They are shaped out of glossy fossilized tuff and both hand-axes are carefully chipped on both faces and the butt-end. One of the cutting-edges of the almond-shaped specimen has a tendency towards the ' $S$ ' twist. An implementiferous boulder bed was noticed on the left bank, $11 / 2$ metre above the river. It is situated exactly opposite of the Ngambar tributary. The rolled tools were found in the upper portion of this bank. In May $1954 \mathrm{Mr}$. Basoeki made a ten-day stay at Punung; on this occasion the Baksoka Valley was mapped over a distance of eight kilometres. The Tabuhan area was explored again by us in June 1954 during a stay of 17 days. The trial excavation in the Songterus Cave was finished, but no palaeoliths were discovered. New implementiferous terraces were located: at Kiut, this time another (red) gravel terrace with palaeoliths on the right bank of the Sunglon River at an altitude of 11.5 metres above the river. At the right bank of the Serikan River an implementiferous terrace was discovered 5 metres above stream level. In the dry watercourse of the same river we collected a well-finished hand-axe and a fine 'Flatiron' chopper. A small excavation carried out in the one-metre bank of the Sunglon River proved that the tools were embedded in the upper portion only; the tools were waterworn. A one-day trip to the Baksoka Valley resulted in the discovery of an implementiferous terrace at the right bank, 4 metres above stream level. Besides, we recognized a dissected terrace with lateric gravel, 15-20 metres above the river; it is thus 
by far the highest in the series. This bed has several metres of red clay on top. In total 133 unrolled stone implements were collected, among these were 27 choppers, 2 chopping-tools, 1 hand-adze, 8 proto-hand-axes, 3 hand-axes, 1 cleaver, and a great number of flake-tools and trimming flakes showing signs of use. They were made from silicified limestone and are entirely stained red, caused by their lying in the red clay for an indefinite period. The site in question was mapped by $\mathrm{Mr}$. Basoeki in September 1954.

In brief outline we have shown that post-war discoveries by the present writer and his associates have revealed new localities, notably in the Tabuhan area, north of Punung. In the region under consideration, the Gedeh River and the Sunglon River both break through the karstified hills on two places. The first tools have been found near the Gedeh River proper. But is was not possible to locate any gravel terraces on its banks. Only on the right bank a low gravel bank was noticed with some palaeolithic tools. It was situated only one metre above the river level. Apparently the terraces (abandoned stream-levels of the ancestral river) are missing here; they have been removed by erosive action or they are superposed by a mantle of clay.

More successful were the investigations in the Sunglon Valley where four defined implementiferous levels were exposed, respectively on 1, 6,11 and 20 metres above stream-level, while the small Serikan River furnished proof of the existence of at least two different implementiferous horizons: one low bouldergravel at $1 / 2$ metre and a gravel terrace at 5 metres above the river. The tools from the low banks were found in the upper portion only and they are heavily rolled. Therefore, I presume that the tools are brought down by erosive wateraction from a higher level and that they are secondarily deposited. It is noteworthy that similar low banks accompany the Sunglon, Serikan, Gedeh and Baksoka rivers and their tributaries on both sides at an altitude of $1 / 2-2$ metres above river-level. The terrace sequences of the Baksoka and the Sunglon Valleys correspond very well and they have many features in common. They are characterised by four implementiferous terraces, showing a similar system of ancient stream-levels and four distinct cycles of erosion.

The most important terrace seems to be the 15-20 metres terrace of the Baksoka Valley. It is the highest and oldest in the sequences and is the most prominent in this region. In contrast to the tools from the lower terraces and those of the riverbed, the implements are not waterworn and are made of silicified limestone. Apparently the tools have been fashioned during a period when the karst was nascent and 
before the river wore down its bed into the volcanic breccias and the silicified tuff became available to the toolmakers. During this stage the Trinil fauna perhaps occupied the region, their fossil remains have been found by von Koenigswald 52 in fissures and sinkholes (bear, tapir, Simia, Stegodon, Elephas namadicus, Echinosorex, Symphalangus and Hylobates). Accordingly, the tools from this terrace may be of late Middle Pleistocene antiquity, but the Patjitanian persisted without any significant innovations into the first part of the Upper Pleistocene. These and other indications go to prove that the Patjitanian of the High Terrace and the lower terraces form a single culture. Therefore, it seems clear that the Patjitanian shows an excessive slowness in the tempo of change in tool technique and in creating new forms.

The technique employed in working the Patjitanian tools is essentially monofacial, as has been already stated by Movius. 53 The flake tools which seldom exhibit either a bulb of percussion or a strikingplatform, outnumber the pebble-tools by far. But the Patjitanian is characterised also, by a great number of massive tools like choppers, chopping-tools, hand-adzes, proto-hand-axes, peculiar cleavers, a low percentage of bifaces or hand-axes and the absence of true Levallois flakes. The massive tools are made from rough chunks of silicified tuff and pebbles, the oldest from silicified limestone and a few from fossil wood. It is not uncommon to find that the butts are left untrimmed with a considerable part of the original crust of the pebble adhering to it. As has been presumed by Movius, the Patjitanian demonstrates a fundamental similarity with, and is closely allied to the Anyathian of Upper Burma, both forming part of the great Chopper/Chopping-tool Complex of Southeastern Asia. Some conspicuous, not uncommon forms are 'Flatiron' shaped choppers and 'Turtle-back' choppers; some of the former are 'keeled', resembling in some respects 'rostro-carinates'. As said before, the Patjitanian comprises a low proportion of bifaces. Many of these are flatter and much less flaked on the lower than on the upper face. It is equally true that many of these show a technique of stone flaking, notably endlong trimming parallel to the axis of the object closely resembling the chopper tradition. Nevertheless, it can not be ignored that we found a number of bifaces with regular outlines. There were ovates, round and almond forms and elongate thick-butted shapes, some of them showing slightly ' $\mathrm{S}$ ' twisted cutting-edges. Movius makes the suggestion that the Patjitan bifaces are locally developed, notably the pointed

52 Von Koenigswald; '40, 197.

53 Movius; '49, 355. 

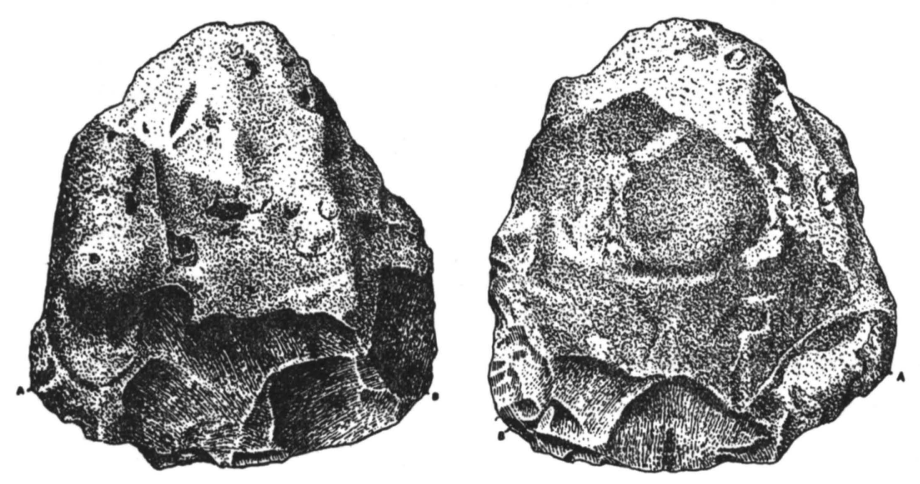

CHOPPING - TOOL. GEDEH RIVER $125 \times 117 \times 56 \mathrm{~mm}$.

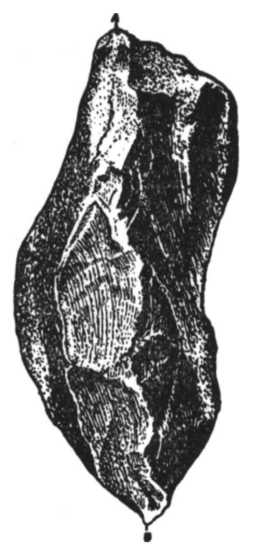

Fig. $7 a$.

specimens evolved from the choppers and the ovates developed from the chopping-tools. In spite of the fact that thus far no bifaces have been found in Upper Burma and Ceylon, the hand-axes probably indicate the introduction of foreign forms from Peninsular India. In this connection attention must be drawn to the fact that true bifaces were already well developed in the Early Patjitanian of the highest terraces in the sequences. The fact remains, however, that only a small proportion of

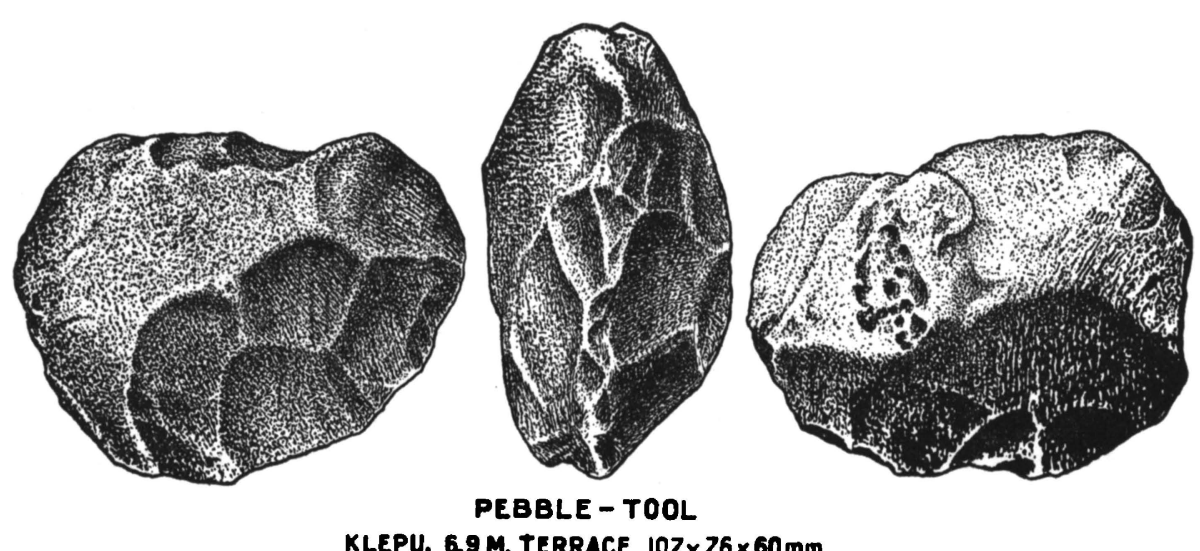

KLEPU. 6.9 M. TERRACE $107 \times 76 \times 60 \mathrm{~mm}$

Fig. $7 b$. 
the tools may be labelled as classic Acheulean, and that Levallois tools are completely absent (Pl. 7-13; Fig. 7a, 7b; 8a, 8b).

Not much is known about the spatial distribution of the Patjitanian on Java, but sites with similar tools are known from Tasikmalaja (discovered by Dr Ostberger) and southwest of Sukabumi (by Erdbrink) and at Gombang and Parigi in Central and East Java (by Houbolt ${ }^{54}$ ).

b. Borneo and Sumatra.

In 1939 the geologist $\mathrm{H}$. Küpper discovered five pebble-tools and two flake-implements on a gravel terrace above the south bank of the Riam Kanan River at Awangbangkal, approximately 16 kilometres southeast from Martapura in South East Borneo. It is not at all sure, though fairly probable, that they are of Pleistocene age and may be referred to the Lower Palaeolithic Chopper/Chopping-tool Complex on the basis of comparison. The dressing of the pebble is always confined to one face and the tools are worked after a manner now known as choppers. The assemblage contains elements that are especially comparable to the Fingnoian of Siam. (Fig. 9). More investigations in the field are needed before we shall know for certain whether the artifacts are of Pleistocene age.55 The same holds for Lower Palaeolithic sites in South Sumatra where monofacial stone tools, mostly shaped out of fossil wood and volcanic rock, were collected by Houbolt from the valley of the Mungup River, near Tambangsawah, by Soejono and Basoeki from the gravelbed of the Kikim River near Tebingtingih and on the Kedaton rubber estate, near Tandjong Karang by Erdbrink. ${ }^{56}$ All these sites are entirely devoid of fossil mammal remains and the reports in question are sparse and vague. Therefore, a definite conclusion will depend on future research.

64 Houbolt; '40, 614-17.

65 Van Heekeren; '51b, 510-12.

56 Movius; '55, 526. 

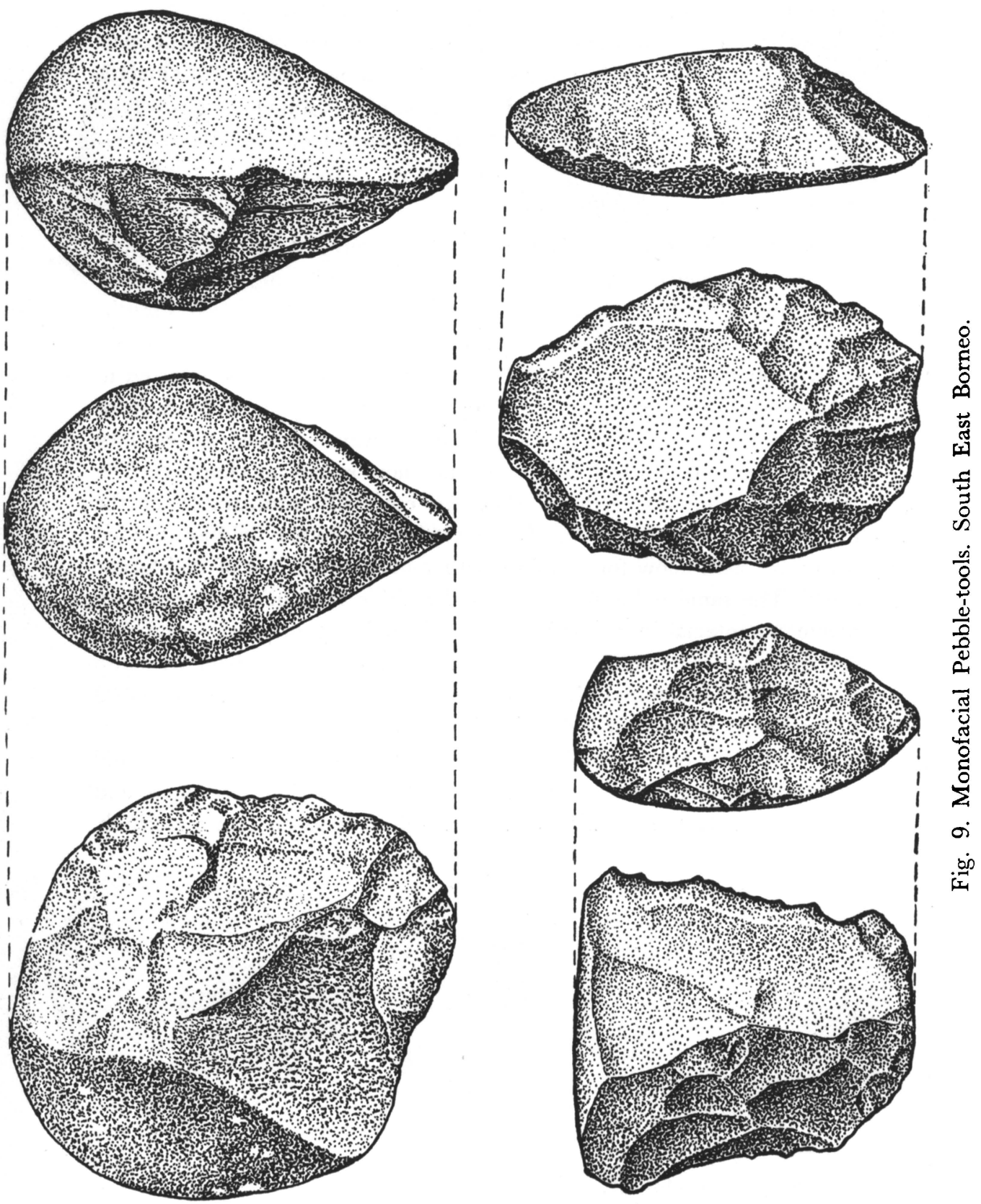


\section{THE UPPER PLEISTOCENE.}

"Following this phase of uplift, new drainage lines were established in Early Upper Pleistocene times. A new type of Man - Solo Man - appeared with strong Neanderthaloid affinities. His migration may be connected with the emergence of Sundaland during the Third Glacial Stage. Stream terraces and alluvial formations contain records of prehistoric cultures".

Hellmut de Terra.

\section{A. The Notopuro Beds and Stream Terraces.}

The Notopuro Beds have two striking features. In the first place, their composition is rather divergent; in the second place, near Sangiran, they unconformably overlie the Middle Pleistocene Kabuh Beds. In the deposits are large boulders from the Lawu eruptions. Between the villages of Ngawi and Trinil lie similar deposits, made up of fine, gray tuffaceous layers. Beds of the same antiquity are present, with interruptions, along the slopes of the Kendeng Hills which are not so well known and have as yet not been examined in as much detail as the older layers. For often they appear to have been partly or completely washed away, or else they are overlain by recent alluvial layers. In the gravels round Sangiran numerous flake implements of a yellow chalcedony occur, as discussed on page 43 .

Of the same period are the high river terraces, bordering the Solo River Valley, which were reported as early as 1908 by J. Elbert as containing fossil remains of vertebrates. In Java, such terraces seem to have developed exclusively in the Upper Pleistocene during late stages of the uplift of the Kendeng Hills, which caused the river to incise itself vigorously until its equilibrium was regained, while the ancient terraces remained. They unconformably overlie the ancient folded deposits and as they escaped the last folding which took place during the interval between the Middle and the Upper Pleistocene, they must have developed after the folding.

Long after Elbert, the Solo terraces attracted the attention of ter Haar, who discovered new fossiliferous terraces along the Solo River in 1931. An almost complete skull with horns of a palaeokerabau was recovered at Kuwung. Later excavations were undertaken in a +20 metres terrace near Ngandong, situated on the western bank of the river. 57 Here the stream runs through intensively folded Tertiary tuffaceous marls. Apart from remains of this terrace, there are traces of a

57 Oppenoorth; '32, 49-74. de Terra; '43b, 456-57. 
Post-Glacial terrace, 5 to 6 metres above stream-level, and 20 to 30 metres higher up there was another terrace.

The excavations in the second (20 metres) terrace yielded surprising discoveries; during the course of two years as many as 20.000 fossil mammal bones have been found, among which there were 11 human calvarial fragments and two tibiae. The deposits of this second terrace had a maximum of 3 metres; however, it was much thinner elsewhere.

The fossils were recovered from a layer of gravel and sand $40 \mathrm{~cm}$. thick. The chalky-white, calcined fossils are easily distinguished from the older more strongly fossilized and dark-coloured remains. The majority of the fossils as well as the human remains were found in the upper portion of the gravel and sand. Similar terraces exist both up- and down-stream. The terraces at Ngandong, Ngrawoh, Pandejan, Kuwung, Sidoredjo, Sembongan and Ngasiman all contain the Upper Pleistocene Ngandong fauna. The richest site is at Watualang. At Pitu the terraces overlie the Kabuh Beds. 58

\section{B. The Ngandong fauna.}

Two-thirds of the 25.000 fossil vertebrates of the Ngandong fauna consist of remains of the prehistoric banteng, Bos (Bibos) banteng palaeosondaicus Dubois, of which the male and female examples did not appear as differentiated as the recent bantengs. Next in frequence comes the fossil water-buffalo, Bos (Bubalus) bubalis palaeokerabau Dubois, of which an excellently preserved and complete skull with the horns was found; the distance between the horn-tips of this example measures 2.25 metres.

The oldest types of the Trinil fauna have disappeared for the greater part; no antelopes occur and most forms differ only slightly from the recent examples. The Ngandong fauna corresponds in all essential respects with the Narbada fauna of India in that Ursus and Equus are absent. The only extinct form is the highly specialized Stegodon, while Elephas and Hippopotamus no longer occur in Java. Guide forms are Cervus javanicus and Sus terhaari. Von Koenigswald considers the Ngandong fauna as an impoverished Trinil fauna.59 In his recently revised list this fauna comprises the following types:

PRIMATES:

Homo soloensis (Oppenoorth).

58 Von Koenigswald; '34, 185-201.

5 \% Von Koenigswald; '49a, 91-94. 


\section{CARNIVORA:}

Felis palaeojavanica Stremme.

Panthera tigris Linnaeus var.

Panthera pardus Linnaeus.

\section{PERISSODACTA:}

Rhinoceros sondaicus Desmarest.

\section{ARTIODACTYLA:}

Hexaprotodon ngandongensis.

Sus macrognathus Dubois.

Sus brachygnathus Dubois.

Sus terhaari von Koenigswald.

Sus ex. aff. vittatus Müller et Schlegel.

Muntiacus muntjak Zimmermann.

Cervus (Rusa) cf. hippelaphus Cuvier.

Cervus javanicus von Koenigswald.

Bos (Bubalus) bubalis palaeokerabau Dubois.

Bos (Bibos) banteng palaeosondaicus Dubois.

\section{PROBOSCIDEA:}

Stegodon trigonocephalus Martin.

Elephas cf. namadicus Falconer et Cautley.

A few remains of birds from Watualang (a big black stork, a vulture and a crane) have been studied by Wetmore. Especially the last form is of great importance in view of the climatic conditions at those times in Java. Wetmore 60 considers: "There are no records of the occurrence of the crane in Java, and at present time it winters south only to the Yangtze Valley, Hainan, Swatow and Northern India. Pleistocene conditions apparently carried it much farther north and its occurrence in Central Java is of particular interest in its possible indication of climate conditions of the period from which it comes".

C. The Hominids.

a. Homo soloensis (Oppenoorth).

No less than 11 fossil calvaria or calvarial fragments and two tibiae of Homo soloensis have been found by collectors of the Geological

60 Wetmore; '40, 447-50. 
Survey. ${ }^{61}$ Skull I, a calvarium lacking the greatest portion of the base; Skull II a frontal bone; and Skull III, a fragment of a calotte, have been excavated in 1931. Skull IV, a calotte; Skull V and VI, nearly complete calvaria with the bases preserved, and Skull VII, a small fragment of a right parietal bone, were found in 1932. Skull V found by W. F. F. Oppenoorth, and Skull VI discovered by von Koenigswald and ter Haar were observed in situ, resting on their vaults. Skull VIII, two parietals; Skull IX and X, calvaria with the greater portion of the base missing; and Skull XI, an almost complete calvarium, were dug up in 1933. Tibia A consists only of a large fragment of a shaft, and tibia B is nearly complete; they were found respectively in 1932 and 1933.

All these human fossils were recovered from a deposit consisting of sand, gravel and volcanic products of an ancient stream terrace at the village of Ngandong, situated on the left bank of the Solo River, about $11 \mathrm{~km}$. north of Ngawi. The terrace lies 20 metres above the river, and its bed is about 50 metres above sea-level. It probably was an ancient camping-place of Solo Man, the numerous fossil animal remains representing the victims of their meals. A small collection of stone and bone implements was also excavated. The skulls were highly mineralized; their patina is a sepia-brown, in some instances with almost black spots on the top. Some skulls are extraordinarily heavy because of their size and intense fossilization. Skull XI weighs as much as $1153 \mathrm{gr}$.; Skull V: 1139 gr. The skulls, belonging to individuals of different age and sex, have so far been partly and provisionally described by Oppenoorth and ter Haar. ${ }^{62}$ Later Franz Weidenreich had the opportunity to study the originals after the war through the intermediary of von Koenigswald, and only a short time ago the posthumus monograph, especially dedicated to Solo Man, was published.63 His detailed description, provided with many drawings and plates, was not finished due to his sudden death on July 11, 1948.

It is a notable fact that most of the skulls lack the base, which exhibits traces of having been broken away on purpose; such is also true in the case of the skulls of Pithecanthropus pekinensis from North China, where also human bones have been found, split lengthwise and charred. There it was a clear case of cannibalism, a practice they apparently shared in common with Solo Man. This is strengthened by the

61 Oppenoorth; '32a, 49-74. '32b, 704-7. '32c, 105-15. '32d, 269-79. '37, 349-60.

62 Ter Haar; ' $34,51-57$.

63 Weidenreich; '51, 205-90. 
fact that, except for the two tibiae, no other skeletal remains have been found. Despite careful searching, not even a single tooth was discovered. Weidenreich proved that some of the blows delivered on the skulls had not been effective. The skulls of two young individuals clearly showed that the bone had been injured by a blow with a sharp instrument, but at the same time the place of the lesion displayed a fusion of the bone, proving that the individuals must have survived.

The best preserved skulls are I, V, VI, IX and XI. Their bone structure is very robust and heavy; the skulls vary in size, probably largely due to a difference in sex, but for the remainder they seem to have belonged to one and the same type. The cranial bones of the female examples (Skulls I, VI, IX, X), are very thick, too, and even the male Pithecanthropus pekinensis does not have such a thick skull cap. (Pl. 14).

The skulls are notable for the extraordinarily heavy browridges, which protrude both forward and sidewise; the tori are thickest at their lateral ends. They form a nearly straight line and continue without distinct depression into the flat, retreating frontal bone. The nuchal part is flat and forms an angle of nearly $100^{\circ}$ to the occipital plane. At the top of this nuchal plane is a massive cross-protruding ridge or crest to which the cervical muscles are attached. Solo Man must have possessed very heavy neck-muscles. The structure of the occipital portion of the back part of the skull closely resembles that of Rhodesia Man. Viewed from the front, the skull of Solo Man exhibits a feature specific for this type. The greatest breadth is at the level of the supra-mastoid process, almost at the base, and it decreases upwards in height. Beneath the supra-mastoid process the outline of the skull, viewed from the front, bends sharply inwards; other peculiar features are the lowness of the head and the heavy mastoid process.

The greatest skull length varies from $221 \mathrm{~mm}$. (Skull V) to $191 \mathrm{~mm}$. (Skull VI). The average length is $201.8 \mathrm{~mm}$. The greatest breadth is from $146 \mathrm{~mm}$. (Skull VI) to $159 \mathrm{~mm}$. (Skull X). The average breadth is $152 \mathrm{~mm}$. The average length-breadth index is 72.3 and the average length-height index is 61.1 .

Skull XI (Pl. 14) most closely approaches the average and was chosen by Weidenreich as a model for reconstructing the whole skull of Solo Man, Ariëns Kappers has studied the endocranial casts of the skulls I, IV, and V. The shape of the brain appeared to be more primitive than that of the Neanderthalian skull, and in several respects approaches that of Pithecanthropus pekinensis. The form of the calvarium, too, resembles an enlarged and slightly better developed skull of Peking Man. 
Solo Man, therefore is not a true Neanderthalian, but is more primitive and closer to the Pithecanthropus group. Weidenreich sums up 58 special characteristics of Solo Man, of which 55 correspond with those of Peking Man, and only 2 with the Neanderthalian.

The tibiae are heavy, but straight and slender as in recent man. On terraces of the same Upper Pleistocene age implements of stone and bone have been found.

\section{b. Homo (sapiens) wadjakens is Dubois.}

The two fossil Wadjak skulls were discovered as early as 1889 and 1890, but Dubois first described them only in 1920.64 The first skull was found in the Southern Mountains, south of Mount Wilis near the village of Tjampurdarat, where the remains of an ancient lake were present, which to-day is filled with sands and ashes of Mount Wilis. On the limy banks of this old lake were some terraces where van Rietschoten was searching for marble. During his explorations, mineralized mammalian bones, as well as a fossil human skull, later known as Wadjak I, were discovered. This find became known to Dubois, who was staying at Pajakombo at the time. The following year he continued the search and was fortunate in finding a second human skull: Wadjak II. (Pl. 16).

The vertebrates, though fossilized, all appear to belong to recent species. Of this fauna Tapirus no longer exists in Java, and it is likewise absent in the sub-fossil Sampung fauna. 65 Dubois claimed that the deposits were of Pleistocene age. Whether or not this is right cannot be proved, since the site was completely dug away for economic purposes and hence was lost to science. No prehistoric implements have been found, but possibly they were overlooked. De Terra considers that Solo Man is as ancient as the Third Interglacial, whilst Wadjak Man belongs to the Fourth Glacial Stage.66

Both of the Wadjak skulls possess some peculiar characteristics, to wit a combination of primitive and rather progressive features. Skull I is of considerable size, rather heavy and long (200 mm.) and has a brain capacity of $1550 \mathrm{cu}$. cm., which is above the average of recent man. The bone structure is strongly developed and in some parts $10 \mathrm{~mm}$. thick. The forehead is valuted, but sloping slightly backwards. (Pl. 16). Skull II is smaller, but as the bone structure is less thick, it has a still

64 Dubois; '20-21, 88-105, 866-87.

65 See Chapter II.

66 de Terra; '43b, 461-62. 
greater brain capacity, since it measures $1650 \mathrm{cu} . \mathrm{cm}$. (modern Australian aborigines have an average of $1287 \mathrm{cu} . \mathrm{cm}$.). The back of the skull protrudes slightly, but the primitive character of Wadjak Man is demonstrated by the powerful build and size of the palate and the great breadth of the dental arc. The breadth of the ascending ramus of the mandible of Wadjak II is as great as that of Heidelberg Man. There is a projecting chin, which is even more developed than that of recent Australian aborigines. The protuberances above the orbits do not congregate. The orbits are square; the nose is much sunk at the root and has wide nostrils.

Dubois assumes that Wadjak Man is a Proto-Australian, but this assumption is refuted by Sir Arthur Keith and Pinkley. The former points out that there is a resemblance between the great horseshoe-shaped palate of Wadjak II and that of Rhodesia Man, while the dentition also shows an even greater correspondence. However, the incisors, canines and premolars are smaller. Pinkley $\mathbf{6 7}$ is also in disagreement with Dubois; he studied the jaw and the dentition in detail. Although the jaw of Wadjak Man is larger than that of any living human race, the teeth are of sapiens type. Pinkley demonstrated the existence of very primitive features and more evolved characteristics. Wadjak Man is Australmorphic but by no means Proto-Australian. On the other hand, Weidenreich agrees with Dubois and places Wadjak Man in his phylogenetic series of the Pithecanthropus group, in which he is placed after Homo soloensis and before the Australian.

\section{The Sangiran Flake Industry.}

Palaeolithic flake-artifacts were discovered by G. H. R. von Koenigswald as early as 1934. The first site on Java to yield flake-tools is the dome-shaped anticline of Sangiran, north of Surakarta. At first von Koenigswald assumed that the flake-implements which he collected from the surface northwest of Ngebung originated from the uppermost portion of the Middle Pleistocene beds in association with some rolled and derived bones belonging to the Trinil fauna. On this basis he believed that the gravelseries in which the tools were found belong to the Trinil Zone, but Père Teilhard de Chardin, de Terra and Movius disagree with this conclusion. They inspected the Sangiran region in 1938; no tools were found in the Kabuh Beds on that occasion, but in the uppermost gravelseries which were separated by an erosional unconfor-

67 Pinkley; '36, 183-200. 
mity from the underlying volcanic material, and waterlaid deposits of the Kabuh Zone, they collected quite a number of palaeolithic flakes made of chert, chalcedony and jasper. Moreover, de Terra found out that the raw material of which the artifacts were made, does not occur in the Kabuh Beds; on the other hand, pebbles of chalcedony, chert and jasper were found in large quantities in the Upper Pleistocene Notopuro Beds, all along the Kendeng Ridge, extending from south of Semarang to the vicinity of Surabaja.68 In the same year Movius and de Terra collected similar chert and jasper artifacts from the surface of an Upper Pleistocene river terrace near Karsono north of Ngawi.

I had the opportunity to visit Sangiran and the Solo Valley twice in 1952 and again in 1953 and 1955, when more flake-tools were collected. Now at Sangiran there are two factors which may enable us to recognize the Notopuro Beds even at great distances. The red-brown colour of these beds, perhaps caused by ferric oxides, clearly contrasts with the underlying grey-blue Kabuh Beds. And all the Notopuro Beds show one resistant escarpment. At the base, the beds start with a volcanic conglomerate caused by a mud-stream. There is no unanimity among geologists as to whether this layer was laid down during the last stage of the Middle Pleistocene or as early as the onset of the Upper Pleistocene Period. This should not effect the dating of the stone flakes, since all tools were exclusively found in the lower portion of the Notopuro Beds. The coarse conglomerate which unconformably covers the Kabuh Beds is overlain by sand and rivergravel. The total thickness of the Notopuro Beds is more than twenty metres. At Sangiran palaeontological evidence is almost lacking, but at other places, the Notopuro Beds contain a rich Upper Pleistocene Ngandong fauna.

We collected more than seventy flake-tools in the gravel series northwest of Ngebung, south of Putjung, Ngrawan and at Djagan, west of Bapang. The flakes are rather small $(2-6 \mathrm{~cm}$.) and made of shining yellow and brown chalcedony and red jasper. Since these raw materials have never been found in the Kabuh Beds and all flake-tools were collected in the gravels of the Notopuro Beds, an Upper Palaeolithic age can be assumed.

Movius has stated previously that the workmanship of the Sangiran Industry is poor compared with the highly specialized Upper Palaeolithic Blade Cultures of Europe, Africa and the Middle East. The Sangiran flakes comprise scrapers, end-scrapers, ogival points, some borers, core- 

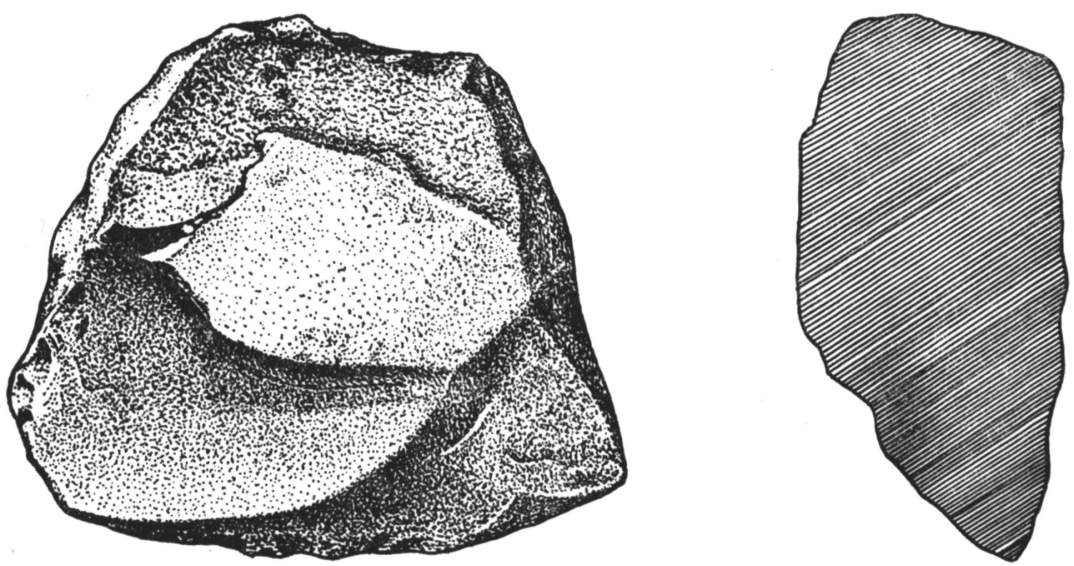

Cleaver fashioned from a massive flake.

Baksoka River. 15-20 m. terrace; $118 \times 126 \times 54 \mathrm{~mm}$.

Fig. 8a.

scrapers and crude blades. Since the remains of Homo soloensis are also of Upper Pleistocene age, the Sangiran Flake Industry may be the work of this kind of Early Man. As a whole, the Sangiran Flake Industry presents a well-developed flake assemblage with a small increment of blades. Most of the flake-tools have a striking-platform at a wide angle to the long axis of the object and display a well-pronounced bulb of percussion and retouches as a result of use. Similar tools have been recorded in the southwest part of Celebes and in the Philippines, but thus far they have not been found on the Asiatic continent. 69

\section{E. The Ngandong Bone Industry.}

Apart from the stone flake-tools of Sangiran type, Solo Man probably also used tools of bone and deer-antlers (Fig. 10). In the Ngandong terrace fossil human skulls were found associated with some stone flake artifacts as well as fragments of deer-antlers, one branch of which was obliquely, the other crudely cut off. Some possessed a sharpened point. Such implements were undoubtedly used as cutting-tools. Spines of stingray from the same layers prove there was a connection with the sea, and suggest that these tools were employed as spear-heads. At Sidoredjo near 
Watualang, a beautiful bone point which had regular barbs on both edges, was found. This spear-head is concave-convex in shape and is made of a long bone; it is $95 \mathrm{~mm}$. long, its greatest breadth being $6 \mathrm{~cm}$. I cannot imagine that this fine tool is the product of Solo Man. Apparently it was not extracted from the fossil bone-bed, but came from a higher horizon. Worthy of mention is the find of a horn chopper made of the antler of the now extinct Cervus (recervus) eldi and that of a second sting-ray spine from Watualang; the latter is $136 \mathrm{~mm}$. long and $6.5 \mathrm{~mm}$. broad. 70 Oppenoorth 71 also reported stone balls with a rough
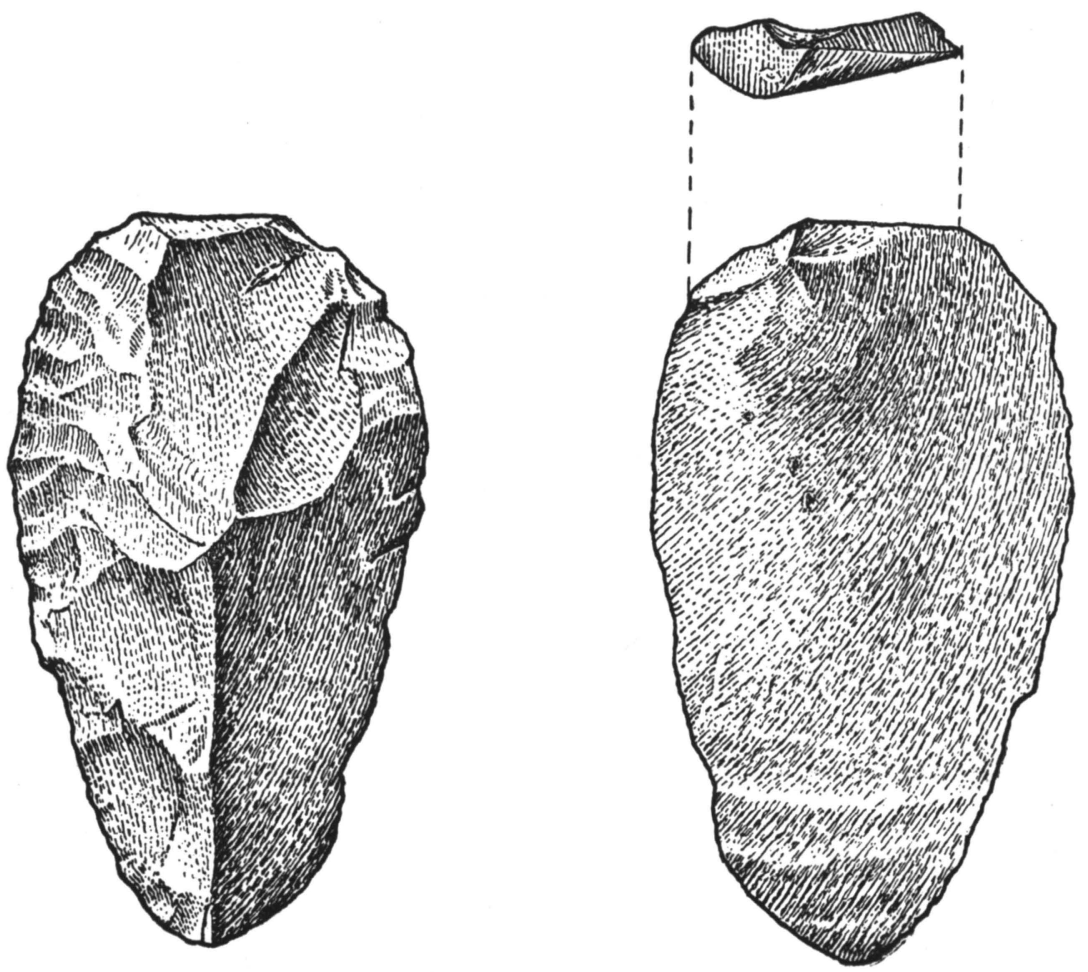

Flake-tool; scraper. Baksoka River.

$78 \times 43 \times 14 \mathrm{~mm}$.

Fig. 8b.

70 Oppenoorth; '36, 399-411.

71 Oppenoorth; '36, 399_411. Movius; '55, 527. 
surface from the river terraces near Ngandong and Watualang. Those of the former terrace have a diameter of 67 tot $92 \mathrm{~mm}$.; of the latter a diameter of 79 to $85 \mathrm{~mm}$. These balls are of andesite, and could be artifacts. Possibly they were employed as pounding stones or sling stones.

\section{F. Celebes.}

Palaeolithic flake-implements and fossil vertebrates have been found recently by the present writer in Soutwestern Celebes. Separated from Borneo only by the relatively narrow but deep Strait of Macassar, Celebes is quite different geomorphologically as well as faunistically. The Macassar Strait has never been less than 25 miles wide during Pleistocene times. It coincides with the so-called Wallace's Line, which indicates the boundary between the Asiatic fauna, on the one hand (Borneo) and the Australian fauna, on the other (Celebes). At first this division was unconditionally accepted by scientists, but later it appeared that over three quarters of the Celebes' neo-fauna consisted of oriental species. However, Wallace's Line is geologically well-founded, and Macassar Strait is a boundary insofar as its marks a sharp division between the rich Asiatic fauna of Borneo and the very poor Asiatic fauna with endemic forms and a few representatives of the Australian fauna found in Celebes. ${ }^{72}$

The geology of Celebes, which should be considered as a real oceanic island, is rather complicated. It represents a combination of uplifts, tectonic fractures, foldings and volcanic activity-features maintained well into historical times and in some instances even up to the present.

During the Tertiary Celebes was composed of a string of small islands. As the result of uplifting, erosion of the mountains and eruptions of the active volcanoes, these islands were joined together in the form of the peculiar four-legged spider that it now exhibits. The Tertiary sediments were folded during Plio-Pleistocene times. Subsequently began the formation of long and narrow bays, basins and coral banks, which owing to a later uplift in the Pleistocene, were elevated to heights of 1000 metres above sea-level, as in the case of Central Celebes. The northern arm of Celebes is the oldest part; it rose from the sea during the Miocene, and shortly thereafter followed a period of intense volcanic activity. The Late Tertiary consists mainly of marine limestone and unconformably overlies the Mesozoic strata.

The southwest part of Celebes (Fig. 11), the area which yielded

72 Hooijer; '51b, 3-8. Mayr; '45, 241-50. 

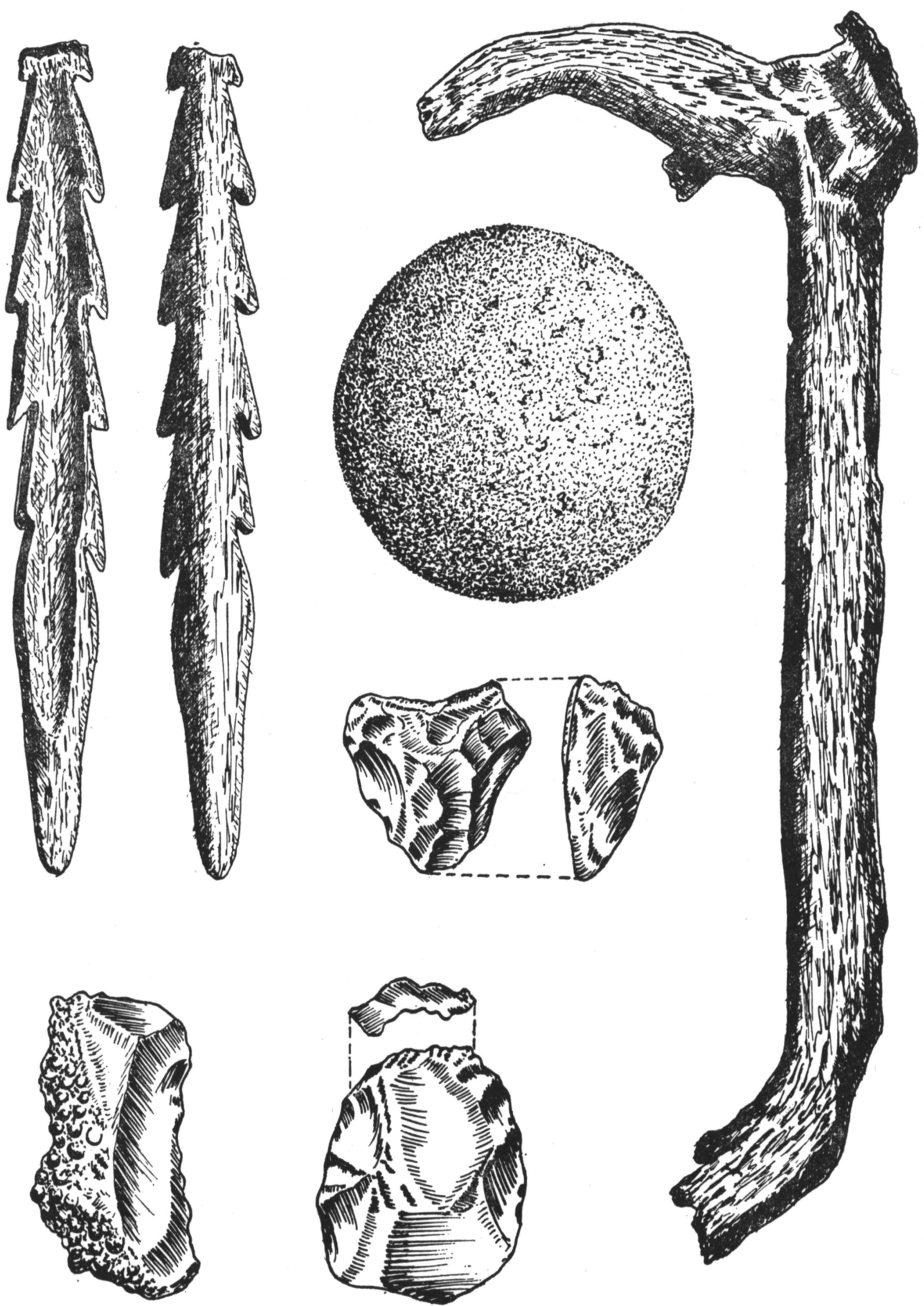

Fig. 10. Upper Palaeolithic tools made of stone, bone and deer-antler.

Solo Valley terraces. 


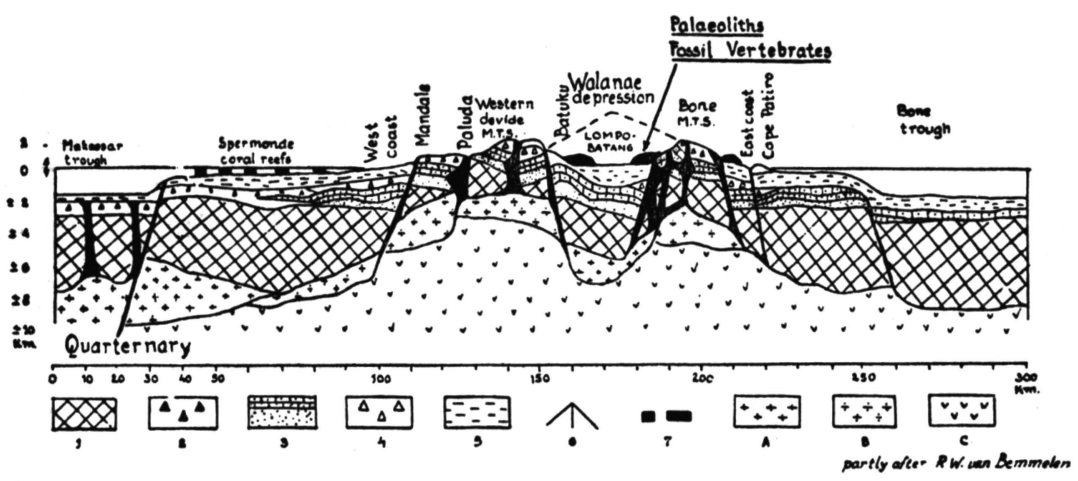

Fig. 11. Geological section through South West Celebes.

Legend: 1. Pre-Tertiary basement complex; 2. Volcanic rocks of Lower-Tertiary age; 3. Coal bearing Eocene and Miocene limestone; 4. Middle-Miocene; 5. Young Neogene sediments; 6. Young Neogene volcanism; 7. Pleistocene coral reefs of the Spermonde Archipelago and raised coral reets in the Walanae Depression and in Bone; $A$. Lower-Tertiary granitic rocks; B. Upper-Tertiary granitic rocks; $C$. Quarternary granitic rocks.

the finds which will be discussed presently, was the most stable for a considerable time. It consists of the western coastal region, the western mountain range, the Wallanae-graben, the eastern Bone mountains and the flat east coast. In the south there is a mountain complex with some volcanoes, extinct since Tertiary times. This mountain range, including the $2871 \mathrm{~m}$. high Lompobatang volcano, covers the Wallanae depression in the south, which continues southwards as far as the Flores Basin. East of Maros, Eocene and Miocene limestone which cover a coalbearing formation, rise steeply at the termination of the Pleistocene erosion surface of Macassar. This plain continues beneath the sea, where it is overlain by the coral reefs and the islands of the Spermonde Archipelago, which developed during Pleistocene and Post-Pleistocene times. ${ }^{73}$

Along the entire foot of the limestone range, the lowermost horizons of which yield Numulites and Orthophragmines and the uppermost part Lepicyclines, there exists a series of caves at a height of $30 \mathrm{~m}$. above sea-level. These caves developed in Post-Glacial times during a temporary interval of quiescence in the uplifting process, and they are partly the result of the erosive activity of the river system. These caves and rock-shelters have been occupied frequently by cave-dwellers in the PostGlacial Period. In the neighbourhood of the village of Patanuang AsuE, at an elevation of $80 \mathrm{~m}$., occurs a lagunal deposit of light-coloured,

73 Brouwer; '24, 153-65. 
massive Miocene reef-bank deposits. In these sediments there occur fossil fishes, crabs and leaves. The fishes can be divided into two groups, one representing pelagic forms, such as Clupeidae, Laranx, Sphyraena, and Serranidae, the other, usually encountered near the steep walls of reefs, such genera as Chaetodontidae, Balista and Scaridae. During the formation of these sediments, there must have been a lagoon which was dry at low tide and protected during the time of high water. This formation has been compared with the famous fossil-bearing malm layers of Solnhofen in some publications.

\section{a. The Discovery of Palaeolithic Implements and Fossil Vertebrates.}

My explorations of the raised coral terraces along the Bone Coastal Plain in the second half of 1946 did not produce sufficient evidence to suggest a Pleistocene occupation by man and other mammals. The search was continued in the Wallanae depression. Towards the end of 1947 I found a number of palaeolithic flake-tools associated with fossil remains of terrestrial animals on a river terrace behind the village of Beru near Tjabengè in the Soppeng district. This terrace was connected with an old river course, more than 25 metres above the present level of the Wallanae River. It was bordered on both sides with cemented gravelseries containing such raw material as yellow chalcedony and red jasper of which the tools were made. The presence of fossil vertebrates and palaeoliths on the same terrace is of special importance, especially as they were the first finds of this kind in Celebes. Although all finds are surface-finds, it is highly probable that they are of the same age. Their Pleistocene age is established, but a more definite date cannot be set for them.

Subsequently, similar vertebrates were found in great numbers on terraces at the same elevation at Sompoh and Tjeleko, which proves that fossiliferous beds extend over a distance up to 25 kilometres. At Sompoh fossil vertebrates were found in great numbers. There the same fauna was found; there were also fossil marine molluscs and numerous teeth of sharks, including Odontaspis cf. cuspidata. But only two flake implements were collected on this terrace.

At the outset it appeared that fossils and palaeoliths only occurred on terraces 50 metres above the level of the sea, but subsequently they were found at Beru and Sompoh on terraces at a level 25 metres higher. It has not yet been possible to identify all the faunas from the several terraces. The bones from the highest level, which are orange-coloured and badly eroded, lay on the hard lateric ground and on the slopes which join both 
the lower and the higher terraces at both Beru and Sompoh. A search for artifacts at Tjeleko proved to be unsuccessful.

The heavily dissected terraces along the Wallanae River may be differentiated into two lower and five upper levels. The third and the fourth from the bottom, 50 metres and 75 metres above sea-level respectively, are fossiliferous. Nearly all stone artifacts were collected from the third terrace, whereas the next lower second terrace yielded only two rolled implements. The investigations between Tjabengè and Sengkang carried out thus far are of a preliminary character, and they had to be suddenly terminated when political troubles arose in this area. Therefore, a large field has been left untouched, which is rather unfortunate, since I am convinced that further search will bring to light fossil human remains. ${ }^{74}$

\section{b. The Fauna.}

Dr D. A. Hooijer, Curator to the Zoological Museum at Leiden, has examined the fossil vertebrates from Celebes and summed up his results in a number of detailed papers 75 and some summaries. ${ }^{76}$ Particularly striking is that none of the animals the remains of which were found, with the possible exception of the giant tortoise, are closely related to those of the Pleistocene of Java. Since they cannot have originated on Celebes, they must have followed de Terra's second migration route: the one from South China to Northern Celebes by way of the Philippines and the Sangihe land-bridge. The animal remains are just as heavily fossilized as are those from the Pleistocene beds of India and Java. The fossils thus far described comprise the following:

1. Archidiskodon celebensis. A pygmy elephant, standing only 6 feet high, about three-quarters the size of the living Asiatic elephant and half as large as the Archidiskodon planifrons of the Lower Pleistocene of Southeastern Asia, to which it is very closely related. The males have tusks in the lower jaw in the mastodont fashion.

2. Stegodon spec. The nature of a number of molar fragments does not permit of more than a generic determination.

3. Celebochoerus heekereni. A new species of giant pig with extremely

74 Van Heekeren; '47c, 109-10. '49a, 492. '49b, 145-146.

76 Hooijer; '48a, 1024-32. '48b, 1169-82. '48c, 1322-30. '49a, 205-6. '50b, 307-8. '53a, 311-18. '53b, 107-12. '53c, 221-31. '54a, 1-46.

'54b, 475-85. '54c, 486-89. '54d, 103-20. '54e, 263-66.

76 Hooijer; '49b, 148-50. '51b, 3-8. '55, 153-63. 
large tusks. It was probably differentiated at an early date from the main stock of Suidae, and its relationship is not yet clear.

4. Testudo margae. A giant land tortoise, which reached a length of 4 to 6 feet. It shows relationship to the giant tortoise which still exists on the Galapagos Islands in the eastern part of the Pacific and on some islands of the Western Pacific. The largest living specimen of Testudo in Southern Celebes is less than half the size of the fossil species.

5. Anoa depressicornis (Smith). This Anoa differs only little from the species living in Celebes.

Besides, remains of fossil sharks (Hemipristis, Carcharhinus, Isurus and Carcharias), ray (Dasyatis), crocodiles and turtles have been found and described.

As the entire collection consists of surface-finds, it is as yet not easy to determine whether all the remains belong to the same faunal group. As has been noted previously, the fossils were collected on two different terraces. Both terraces, at Beru and at Sompoh, yielded remains of $\mathrm{Ar}$ chidiskodon and Celebochoerus, a fact which could argue in favour of the probability that these species belong to the same fauna. The fact that other fossils have been collected from the slope which join these terraces points to the possibility that they originally were embedded in the fourth terrace, whence they may have been washed away and come to rest on the third terrace. On the other hand, however, the mineralogical examination carried out at Leiden proved that the matrix adhering to some of the fossils indicates two different geologic horizons. "The matrix" wrote Hooijer, 77 "of an elephant molar from Sompoh is a riverlaid sediment with volcanic material. The rock consists of detrital grains of lateric sandstone, the interstices partly filled with amorphous limonitic silica and opaque components. There are some pieces of quartz and veins of rhombohedral calcite. The volcanic components consist for the greater part of diopside and a few crystals of alkaline felspar. The matrix of the Anoa teeth from the same site is, however, different, consisting chiefly of calcite grains of irregular form and containing also grains of quartz and alkaline felspar. Almost identical to the latter matrix, but with less alkaline felspar and more quartz, is that of the tortoise bone from Beru. Thus it is evident that there are at least two bone-bearing beds at Sompoh, one of which may be the same as that exposed at Beru".

77 Hooijer; '49c, 149. 

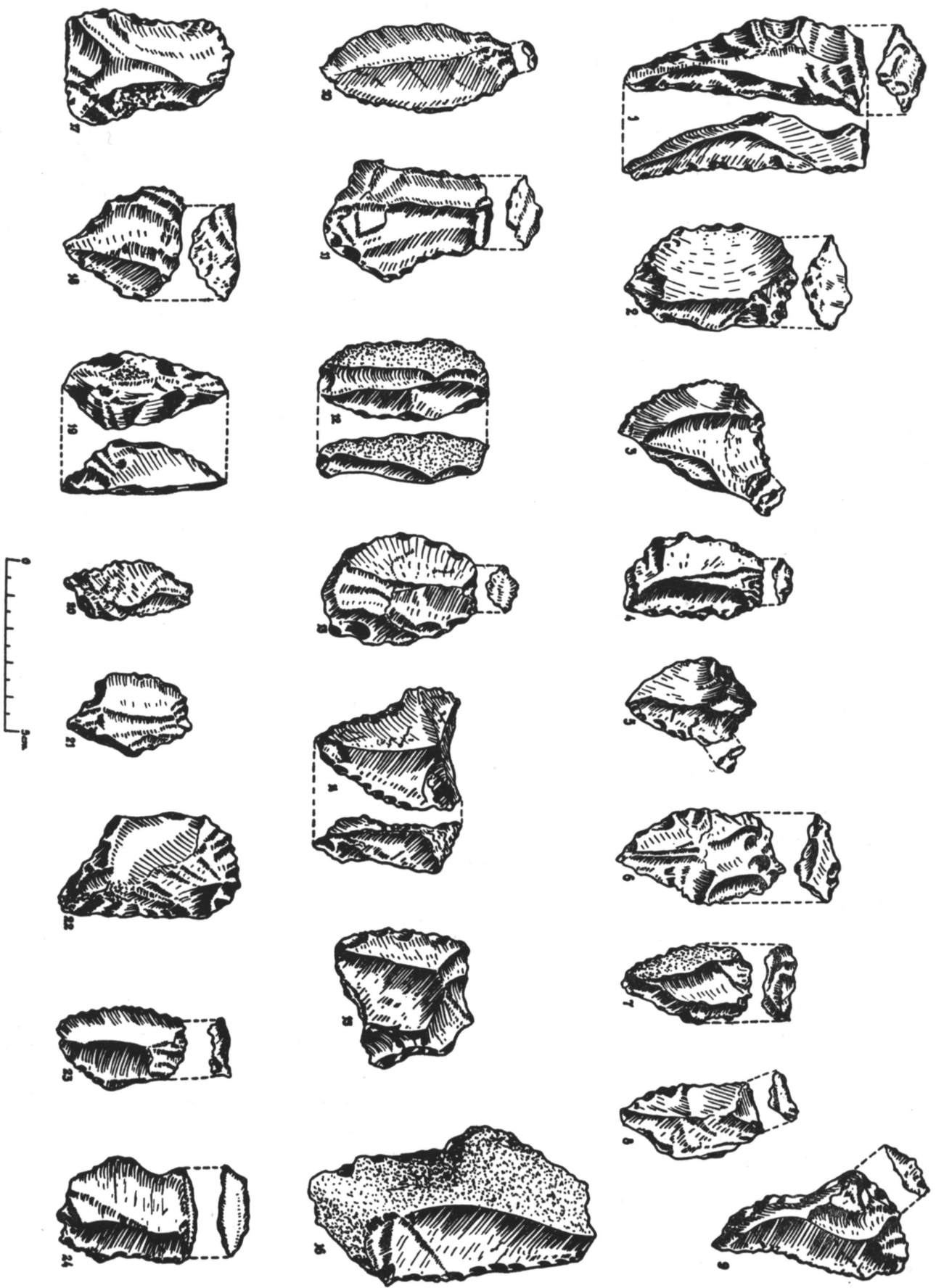

Fig. 12. Upper Palaeolithic Tjabengè Flake-tools. South Celebes. 


\section{c. The Tjabengè Flake Industry.}

From the third terrace at Tjabengè, 67 well-preserved palaeolithic flake-artifacts were collected. Moreover, these deposits yielded more than 100 flakes which in my opinion show traces of some trimming. Also at Sompoh, the third terrace yielded two flake implements. Finally two additional flakes of the same type were found on a lower terrace near Tjabengè ( $25 \mathrm{~m}$. above the level of the sea). It is not impossible that the latter, bearing traces of being waterworn, have been derived from the third terrace. A common feature of the tools is their relative smallness and thickness. The flakes have been struck from irregular cores, and mostly present a clearly defined bulb of percussion and a high angle striking-platform. The material used is mainly chalcedony, jasper and other coloured fine-grained siliceous rocks, in short, carefully chosen material from which the flakes could easily be detached by a blow. The number of types is large. (Pl. 17; Fig. 12). There are thick arched points, crude scrapers, small core-scrapers, keeled scrapers, end-scrapers, and some ogival-points. The striking-platform is nearly always plain and a few are tri-facetted. However, true Levallois types are absent. In addition to purposely struck flakes, there are also natural flakes that have been worked on one side. These objects have no bulb of percussion. A small number of blade-tools comprises a remarkably thin leaf-shaped knife or spear-head with extremely sharp edges. Unquestionably, the Tjabengè Flake Industry is closely related to the Upper Palaeolithic Sangiran Industry of Java. And in both instances the same raw material has been used. 78

The Palaeolithic artifacts and the fossil vertebrates, or at least the largest part of the latter, are presumably of the same age, and the bearers of this stone-culture probably followed the same migration route as the animals did, by way of the Philippines. ${ }^{79}$

78 Van Heekeren; '49b, 145-46.

79 Movius; '55, 531. Von Koenigswald; '53. Otley Beyer; '48, 1-130. In a Pleistocene terrace at Rizal-Bulaka on Luzon and in a pebble quarry at Davao on Mindanao, there occur stone flake artifacts of the same types as those from Sangiran in Java and Tjabengè in South Celebes. On Luzon they were associated with fossil mammals including Stegodon, while on Mindanao fossil remains of pygmy elephants have been found. 


\section{REFERENCES AND SELECTED BIBLIOGRAPHY.}

Adam, W.

1943:

Barbour, G. B.

1934:

1935:

Beaufort, L. F. de 1926:

Bemmelen, R. W. van 1949:

Bergman, R. A. M. and $P$. Karsten.

1952:

Beyer, H. Otley

1947:

1948:

Black, Davidson

1927:

Blanckenhorn, $\mathrm{M}$.

1911:

Bolk, L.

1926:

Boule, M.; Breuil, H. La Paléolithique de la Chine. Archives Inst. Pal.

Licent, E. and Teil- Humaine, Mém. 4, 1-138.

hard de Chardin, P. 1928:

Bouman, K. T. 1938:

Braidwood, R. J. 1947:

Breuil, $\mathrm{H}$.

1931:

The Keilor fossil skull; palate and upper dental arch. Mem. Nat. Mus. Melbourne, 13, 71-77. Analysis of Lushan Glaciation Problem. Bull. Geol. Soc. China, 13, 647-56.

Physiographic History of the Yangtze. Mem. Geol. Surv. China, 14, 1-112.

Zoögeographie van den Indischen Archipel.

Haarlem.

The Geology of Indonesia. 3 vols. The Hague.

The fluorine content of Pithecanthropus and other specimens from the Trinil fauna. Proc. Kon. Ned. Akad. van Wetensch. 55.

Outline Review of Philippine Archaeology by islands and provinces. The Philippine Journ. of Science, 77, 205-373.

Philippine and East Asian Archaeology. Nat. research council of the Philippines, 29, 1-130. Manilla.

On a Lower Molar Hominid Tooth from the Chou Kou Tien Deposit. Palaeontologica Sinica, D 7, 1-28.

Allgemeine Betrachtungen der wissenschaftliche Ergebnisse der Selenka-Trinil Expedition.

Report in: Selenka und Blanckenhorn.

Das Problem der Menschwerdung. Jena.

The Brain-Convolutions of the Pithecanthropus erectus of von Koenigswald. Acta Neerlandica Morphologica, 2, 1-3.

Asiatic Prehistory and the Origin of Man. Journ. Near Eastern Studies, 6, 30-42.

Le feu et l'industrie lithique et osseuse à Choukoutien. Bull. Geol. Soc. China, 11, 147-54. 
1935 :

1939:

1942:

Brouwer, H. A. 1924:

1926:

Carthaus, E.

1911:

Chaney, R. W. 1935a:

1935b:

Clark, J. G. D. 1936:

Colbert, E. H.

1935:

1942:

1943:

Collings, H. D. 1938:

Cosijn, J.

1931:

Croll, J.

1875:

Dickerson, R. E. 1941:
Le grand gisement. L'Anthropologie, 45, $740-46$.

Bone and Antler Industry of the Choukoutien Sinanthropus site. Palaeontologica Sinica, D 6, 7-41.

Pithecanthropus en de eerste verbreiding der menschheid. Geneeskundige Bladen, 8/9, 215-74.

Geologische beschrijving der omgeving van de tertiaire fossielrijke lagen nabij Patanoeang AsoeE in Zuid Celebes. Jaarboek Mijnwezen, $153-65$.

History of the Strandlines in the Netherlands East Indies during Pleistocene and Post-Pleistocene Times. Proc. of the Third Pan-Pacific Science Congress. Tokyo.

Zur Geologie von Java. Report in: Selenka und Blanckenhorn, 1-33.

The occurrence of Endocarps of Celtis barbouri at Choukoutien. Bull. Geol. Soc. China, 14, 99-113.

The Food of Peking Man. Carnegie Inst. Vol. 3, 25, 199-202.

Archaeological work in the Malay Peninsula and Java. Proc. Prehist. Soc., Cambridge 2, 251. Siwalik Mammals in the American Museum of Natural History. Bull. Am. Mus. Nat. Hist., $74,255-436$.

The Pleistocene Faunas of Asia and their relationship to Early Man. Trans. N. Y. Acad. Sci., 5, 1-10.

Pleistocene Vertebrates collected in Burma by the American Southeast Asiatic Expedition. Trans. Am. Phil. Soc., 32, 395-429.

Pleistocene Site in the Malay Peninsula. Nature, 142, 575-76.

Voorloopige Mededeelingen omtrent het voorkomen van fossiele beenderen in het heuvelterrein ten Noorden van Djetis en Perning. Verh. Geol. Mijnbouwk. Genootsch. Ned. en Kol. Geol. Serie, 9, 113-39.

Climate and time. London.

Molengraaff River: A Drowned Pleistocene Stream and other Asian evidences bearing upon the Lowering of Sea Level during the Ice Age, shiftings of Sea Floors and Coast Lines. Univ. of Penn. Press, Philadelphia, 13-30. 
Dubois, E.

1894:

1896:

1908:

1921:

1924a:

1924b:

1932:

1933:

1934:

1936:

1937a:

1937b:

1938a:

1938b:

Duyfjes, J.

1936:
Pithecanthropus erectus, eine menschenähnliche Uebergangsform aus Java. Batavia. Also in Jaarboek van het Mijnwezen, 24, 5-77.

On Pithecanthropus erectus: A transitional between Man and the Apes. Scient. Trans. Royal Dublin Soc., 6, 1-18.

Das geologische Alter der Kendengschichten oder Trinil fauna. TAG, 25, 1235-70.

De Proto-Australische fossiele Mensch van Wadjak, Java. Versl. Kon. Ned. Akad. van Wetensch., 29, 88-105, 866-87.

On the principal characters of the cranium and the brain, the mandible and the three teeth of Pithecanthropus erectus. Ibid, 27, 265-78.

Figures of the calvarium and endocranial cast, a fragment of the mandible and three teeth of Pithecanthropus erectus. Ibid, 27, 459-64.

The distinct organization of Pithecanthropus of which the femur bears evidence, now confirmed from other individuals of the described species. Ibid, 716-22.

The shape and the size of the brain in Sinanthropus and in Pithecanthropus. Ibid, 415-422. New evidence of the distinct organization of Pithecanthropus erectus. Ibid, 850-52.

Racial indentity of Homo soloensis Oppenoorth (incl. Homo modjokertensis von Koenigswald) and Sinanthropus pekinensis Davidson Black. Ibid, $1180 \_85$.

The osteane arrangement of the thigh-bone compacta of man identical with that, first found of Pithecanthropus. Ibid, 864-70.

On the fossil human skulls recently discovered in Java and Pithecanthropus erectus. Man, $1-7$.

The mandible recently described and attributed to the Pithecanthropus by $G$. H. R. von Koenigswald, compared with the mandible of Pithecanthropus erectus described in 1924 by Eugène Dubois. Proc. Kon. Ned. Akad. van Wetensch., 139-47.

On the fossil human skull recently described and attributed to Pithecanthropus erectus by G. H. R. von Koenigswald. Ibid, 380-86.

Zur Geologie und Stratigraphie des Kendenggebietes zwischen Trinil und Soerabaja (Java). De Ingenieur in Ned. Indië. IV, vol. 3, 136-49. 
Elbert, J.

1907:

1908:

1909:

1911:

Es, L. J. C. van

1931:

1933:

Gill, W. D.

1952:

Graham, D. C.

1935:

Gros Clark, W. E. le 1945:

1946:

1955:

Haar, C. ter 1934:

Hawkes J. and de Terra, $\mathrm{H}$.

1934:

Heekeren, H. R. van 1941:

1947a:

1947b:

1947c:

1948:

1949a:
De nieuwste onderzoekingen over het Pithecanthropus vraagstuk. Natuurk. Tijdschr. voor Ned. Indië. 67, 125-42.

Ueber das Alter der Kendeng-Schichten mit Pithecanthropus erectus Dubois. Neues Jahrbuch für Mineralogie, Geologie und Palaeontologie, 15, 684-62.

Dubois' Alterbestimmungen der KendengSchichten. Centrabl. f. Min., 513-20.

Die Selenka'sche Trinil-Expedition und ihr Werk. Ibid, 736-41.

The Age of Pithecanthropus. Den Haag.

L'Homme fossile aux Indes Néerlandaises.

Report 16th Internat. Geol. Congress, 1231-37. The Stratigraphy of the Siwalik Series in Northern Potwar, Punjab, Pakistan. Quart. Journ. Geol. Soc. London, 107, 375-94.

Implements of Prehistoric Man in the West China. Union University Museum of Archaeology. Journ. West China Border Res. Soc., 7, 47-56.

Pithecanthropus in Peking. Antiquity, 19, 1-5.

Pleistocene chronology in the Far East. Ibid, 20. $9-12$.

The fossil evidence for Human Evolution.

The University of Chicago Committee, 81-112. Homo soloensis. De Ing. in Ned. Indië, 4, 51-57.

Palaeolithic Human Industries in the Northwest Punjab and Kashmir and their Geological Significance. Mem. Conn. Acad. Arts and Sci., 8, 1-15.

Korte Chronologie van het Palaeolithicum op Java. Djawa, 251-67.

Stone-Age Discoveries in Siam. Chronica Naturae, 103, 1-2.

Stone Axes from the 'Railroad of Death'. Ill. London News, 210, 5633, 359.

Voorlopige Mededeling over palaeolithische vondsten in Zuid Celebes. Oudheidk. Verslag, B (1941-47), 109-10.

Prehistoric Discoveries in Siam, 1943-44. Proc. Prehist. Soc. Cambridge, 14, 24-32.

Early Man and Fossil Vertebrates on the Island of Celebes. Nature, 163, 4143, 492. 
1949b:

1951a:

1951b:

1955a:

1955b:

Heine Geldern, R. 1945:

Hooijer, D. A. 1946:

1947a:

1947b:

1947c:

1948a:

1948b:

1948c:

1948d:

1949a:

1949b:

1949c:
Preliminary Note on Palaeolithic Finds on the Island of Celebes. Chronica Naturae, 105, 5, $145-46$.

De Vroeg-Palaeolithische Patjitan Cultuur en haar betekenis. TBG, 84, 4, 498-507.

Het Hoabinhien op Zuid Oost Borneo? TBG, $84,4,510-12$.

New investigations on the lower palaeolithic Patjitan culture in Java. Bull. of the Archaeol. Service of the Republic of Indonesia. 1, 1-12. Prehistoric Life in Indonesia. Djakarta.

Prehistoric Research in the Netherlands Indies. Science and Scientists in the Neth. Indies, 29-67.

Prehistoric and Fossil Rhinoceroses from the Malay Archipelago and India. Zool. Med. Rijksmus. van Nat. Hist. te Leiden, 26, 1-38.

A Femur of Manis palaeojavanica Dubois from Western Java. Proc. Kon. Ned. Akad. van Wetensch., 50, 413-18.

On Fossil and Prehistoric remains of Tapirus from Java, Sumatra and China. Zool. Med. Rijksmus. van Nat. Hist. te Leiden, 27, 253-99.

Pleistocene remains of Panthera tigris subspecies from Wanhsien, Szechwan, China, compared with Fossil and Recent Tigers from other localities. Amer. Mus. Novitates, 1346, 1-17.

Pleistocene Vertebrates from Celebes, I-Celebochoerus heekereni. Proc. Kon. Ned. Akad. van Wetensch., 51, 8, 1024-32.

Pleistocene Vertebrates from Celebes. II-Testudo margae. Ibid. 51, 9, 1169-82.

Pleistocene Vertebrates from Celebes. III-Anoa depressicornis and Babyrousa babyrussa beruensis. Ibid, 51, 10, 1322-30.

Prehistoric Teeth of Man and the Orang-Utan from Central Sumatra, with notes on the fossil Orang-Utan from Java and Southern China. Zool. Med. Rijksmus. van Nat. Hist. te Leiden, 29, 175-301.

Pleistocene Vertebrates from Celebes. IV-Archidiskodon celebensis. Zool. Med. Rijksmus. van Nat. Hist. te Leiden, 30, 205-26.

The Pleistocene Vertebrates of Southern Celebes. Chronica Naturae, 105, 5, 148-50.

Some notes on the Gigantopithecus Question. Amer. Journ. Phys. Anthr., 7, 4, 513-18. 
1950a:

1950b:

1951a:

1951b:

1952:

1953a:

1953b:

1953c:

1954a:

1954b:

1954c:

1954d:

1954e:

1955:

Hooijer, D. A. and Colbert, E. H. 1951:

Hooton, E.

1946:

Hopwood, A. T. 1940:

Houbolt, J. H. 1940:
The Fossil Hippopotamidae of Asia, with notes on the Recent Species. Zool. Med. Rijksmus. van Nat. Hist. te Leiden, 8, 1-124.

A further note on the canines of Celebochoerus. Ibid., 30, 307-8.

The Geological Age of Pithecanthropus, Meganthropus and Gigantopithecus. Amer. Journ. Phys. Anthr., 9, 265-81.

Pygmy Elephant and Giant Tortoise. Scientific Monthly, 72, 3-8.

Fossil Mammals and the Plio-Pleistocene Boundary in Java. Proc. Kon. Ned. Akad. van Wetensch., 55, 436-43.

Pleistocene Vertebrates from Celebes. V-Lower Molars of Archidiskodon celebensis Hooijer.

Zool. Med. Rijksmus. van Nat. Hist. te Leiden, 31, 311-18.

Pleistocene Vertebrates from Celebes. VI-Stegodon sp. Ibid, 32, 107-12.

Pleistocene Vertebrates from Celebes. VII-Milk Molars and Premolars of Archidiskodon celebensis Hooijer. Ibid, 32, 221-31.

Pleistocene Vertebrates from Celebes. VIIIDentition and skeleton of Celebochoerus heekereni Hooijer. Ibid, 24, 1-46.

Pleistocene Vertebrates from Celebes. IX-

Elasmobranchii. Proc. Kon. Ned. Akad. van Wetensch., 57, 475-85.

Pleistocene Vertebrates from Celebes. X-Testudinata. Ibid, 57, 486-89.

Pleistocene Vertebrates from Celebes. XI-

Molars and a tusked mandible of Archidiskodon celebensis Hooijer. Ibid, 32, 103-20.

Crocodilian remains from the Pleistocene of Celebes. Copeia, 4, 263-66.

Gewervelde dieren uit het Quartair van

Celebes. Vakblad voor Biologen, 10, 153-63. A note on the Plio-Pleistocene Boundary in the Siwalik Series of India and in Java. Amer. Journ. Sci., 249, 533-38.

Up from the Ape. New York.

Fossil Mammals and Pleistocene Correlation. Proc. Geol. Assoc. London, 51, 79-88.

Bijdrage tot de kennis van de verspreiding van Palaeolithische artefacten in Nederlandsch Indië. TBG, 80, 614-17. 
Kappers, C. U. Ariëns and Bouman, $\mathrm{K}$. $\mathrm{H}$. 1939:

Keith, Arthur 1921:

Kleiweg de Zwaan, J. P.

1955:

Kloss, C. Boden 1929:

Krempf, A and Chevey, P. 1934:

Koenigswald, G. H. R. von 1933a:

1933b:

1934:

1935a:

1935b:

1936a:

1936b:

1936c:

1936d:

1937a:

1937b:

1938a:

1938b:
Comparison of the endocranial casts of the Pithecanthropus erectus skull. Proc. Kon. Ned. Akad. van Wetensch., 42, 30-40.

The discovery of Fossil remains of Man in Java, Australia and South Africa. Nature, 106, $603-4$.

De oudste Mensheid in Europa en Indonesië.

The Zoo-geographical Boundaries between Asia and Australia and some Oriental Sub-regions. Bull. Raffles Museum, 2, 1-10.

The Continental Shelf of French Indo China and the relationship which formerly existed between Indo China and the East Indies. Proc. 5th Pacific Science Congr., 2, 58-90.

Beitrag zur Kenntnis der fossilen Wirbeltiere Javas. Wetensch. Meded. Dienst v. d. Mijnbouw in Ned. Indië, 23, 1-185.

Ein neuer Urmensch aus dem Diluvium Javas. Centralbl. für Min., Geol. u. Pal. B, 29-42.

Zur Stratigrafie des javanischen Pleistocän.

De Ing. in Ned. Indië, 4, 185-201.

Die fossile Säugetierfauna Javas. Proc. Kon. Ned. Akad. van Wetensch., 38, 188-98.

Eine fossile Säugetierfauna mit Simia aus Südchina. Ibid, 38, 872-79.

Ein fossiler Hominide aus dem Altpleistocän von Java. De Ing. in Ned. Indië, 3, 149-57. Erste Mitteilung über einen fossilen Hominiden aus dem Altpleistocän Ostjavas. Proc. Kon. Ned. Akad. van Wetensch., 39, 1000-9.

Early Palaeolithic Stone Implements from Java. Bull. Raffles Museum, 1, 52-60.

Ueber Altpalaeolithische Artefakte von Java. TAG, 53, 41-44.

A Review of the Stratigraphy of Java and its Relation to Early Man. In: Early Man. ed. by G. G. MacCurdy, 23-32.

Ein Unterkieferfragment des Pithecanthropus aus den Trinilschichten Mitteljavas. Proc. Kon. Ned. Akad. van Wetensch., 40, 883-93.

Ein neuer Pithecanthropus-Schädel. Ibid, 41, 3-10.

Nieuwe Pithecanthropus vondsten uit Midden Java. Natuurk. Tijdschr. voor Ned. Indië, 98, 195-207. 
1938c:

1939a:

1939b:

1939c:

1940:

1947:

1949a:

1949b:

1949c:

1950a:

1950b:

1952:

1953:

Koenigswald, G .H. R. von and Weidenreich, $\mathbf{F}$. 1938:

Lehman, $\mathbf{H}$. 1936:

1937:

Maarel, F. H. v. d. 1932:
Preliminary Note on New Remains of Pithecanthropus from Central Java. Proc. 3rd Congress of Prehistorians of the Far East, 91-95. Das Pleistocän Javas. Quartair, 2, 28-53.

Neue Menschenaffen- und Vormenschenfunde. Die Naturwissenschaften, 27, 617-22.

The Relationship between the Fossil Mammalian Faunae of Java and China with special reference to Early Man. Peking Nat. Hist. Bull., 13, 293-98.

Neue Pithecanthropus Funde 1936-38. Ein Beitrag zur Kenntnis der Praehominiden. Wetensch. Meded. Dienst v. d. Mijnbouw in Ned. Indië, 28, 1-232.

Search for Early Man. Natural History, 56, 8-15.

Vertebrate Stratigraphy. In: Van Bemmelen, 91-94.

The Fossil Hominids of Java. In: Van Bemmelen, 106-11.

The discovery of Early Man in Java and Southern China. Studies in Phys. Anthr. No. 1. Early Man in the Far East. Amer. Assoc. Phys. Anthr., 83-101.

Fossil Hominids from the Lower Pleistocene of Java. Rep. 18th Session, Intern. Geol. Congr., 1948, Part. IX, 59-61.

Ein Elephant der planifrons-Gruppe aus dem Pliocän West-Javas. Eclogae Geol. Helv., 43, 268-74.

Gigantopithecus Blacki von Koenigswald, a Giant Fossil Hominoid from the Pleistocene of Southern China. Anthr. Papers Am. Mus. Nat. Hist., 43, 295-325.

Fossil Mammals from the Philippines. Abstracts and Messages, 8th Pacific Science Congr., 4th Far-Eastern Prehist. Congr. Manilla, 57.

Discovery of an additional Pithecanthropus skull. Nature, 142, 715.

Morphologische Studien auf Java. Geogr. Abh., 9.

Ueber eiszeitliche Krustenbewegungen von

Sunda Archipel. Frankf. Geogr. Hefte, 75-80.

Contribution to the knowledge of the fossil

Mammalian Fauna of Java. Wetensch. Meded.

Dienst v. d. Mijnbouw in Ned. Indië, 15, 1-208. 
Marks, P. 1953:

Mayr, E.

1945:

Miller, G. S.

1923:

Mohler, W. A.

1946:

Molengraaff, G. A. F. 1921:

1929:

Movius, H. L., Jr. 1943:

1944:

1948:

1949:

1953:

1955:

Nilson, E.

1941: and Weber, $M$.
Preliminary note on the discovery of a new jaw of Meganthropus von Koenigswald in the lower middle Pleistocene of Sangiran, Central Java. Indonesian Journal of Nat. Science, 1, 26-33.

Wallace's Line in the light of recent zoogeographic studies. Science and Scientists in the Neth. Indies, $241-50$.

Notes on the casts of the Pithecanthropus molars. Bull. Am. Mus. Nat. Hist., 48, 527-30. Zur Stratigraphie der säugetierführenden Schichten von Java. Experienta, 2, 287-92.

. Modern Deep Sea Research in the East Indies. Geogr. Journ., 57, 95-118.

The Coral Reefs in the East Indian Archipelago, their Distribution and mode of development. Proc. Fourth Pan-Pacific Science Congr., 2, 55-89; 989-1021.

Molengraaff, G. A. F. On the relation between the Pleistocene Glacial

Period and the Origin of the Sunda Sea, and its Influence on the Distribution of Coral Reefs and on the Land and Freshwater Fauna. Proc. Kon. Ned. Akad. van Wetensch., 23, 395-439.

The Stone Age of Burma. Trans. Am. Phil.

Soc., 32, 341-439.

Early Man and Pleistocene Stratigraphy in Southern and Eastern Asia. Papers Peabody Mus. Harvard Univ., 19, 1-125.

The Lower Palaeolithic Cultures of Southern and Eastern Asia. Trans. Am. Phil. Soc., 38, $329-420$.

Lower Palaeolithic Archaeology in Southern Asia and the Far East. Am. Assoc. Phys. Anthr., $17-81$.

Old World Prehistory. In: Anthropology Today, 163-92.

Palaeolithic Archaeology in Southern and Eastern Asia, exclusive of India. Journal of World History, VII, 257-82; 520—53.

Die Eiszeit in Indien. Meddelanden fran Stockholm Högskolan Geologiska Institut, $54,1-23$.

Oppenoorth, W. F. F. Homo (Javanthropus) soloensis, een pleistocene 1932a: mensch van Java. Wetensch. Meded. Dienst v. d. Mijnbouw in Ned. Indië, 20, 49-74.

1932b:
Een nieuwe fossiele Mensch van Java. TAG, $49,704-7$. 
1932c:

1932d:

1936:

1937:

Oudheidkundig

Verslag

1948:

1949:

Pannekoek, A. J. 1949:

Penck, A.

1933:

Pinkley, G.

1935:

Pei, W. C.

1937:

1939:

Pilgrim, G. E.

1944:

Pottier, G.

1944:

Raven, H. C.

1935:

Regteren Altena,

C. O. van

1938:

Rensch, B.

1936:

1937:

Sankalia, H. D.;

Subraro, B;

and Deo, S.B.

1953:

Schuster, J.

1909:
De vondst van palaeolithische menschelijke schedels op Java. De Ing. in Ned. Indië, 13, 105-15. Ein neuer diluvialer Urmensch von Java. Natur und Museum, 62, 269-79.

Een prehistorisch Cultuur-Centrum langs de Solo Rivier. TAG, 53, 399-411.

The Place of Homo soloensis among Fossil Man. In: Early Man ed. by G. G. MacCurdy, $349-60$.

Werkzaamheden van de Praehistoricus, 19-10.

Werkzaamheden van de Praehistoricus, 17-19. Outline of the Geomorphology of Java. TAG, $66,270-326$.

Eustatische Bewegungen des Meeresspiegels während der Eiszeit. Geol. Zeitschr. 329-39. The significance of Wadjak Man, a fossil Homo sapiens from Java. Peking Natural History Bulletin, 10, 183-200.

Palaeolithic industries in China. In: Early Man, ed. by G.G. MacCurdy, 221-32.

An attempted Correlation of Quarternary Geology, Palaeontology and Prehistory in Europe and China. Univ. of London, 2, 3-13.

The Lower Limit of the Pleistocene in Europe and Asia. Geol. Mag., 81, 28-38.

L'Homo soloensis ou Javanthropus. Bull. Soc. Préhist. franc., 41, 184-86.

Wallace's Line and the distribution of IndoAustralian mammals. Bull. Am. Mus. Nat. Hist., 168, 179-293.

The marine Mollusca of the Kendeng Beds (East Java). Leidsche Geol. Meded., 10, $241-320$.

Die Geschichte des Sunda-Bogens: eine tiergeographische Untersuchung. Berlin.

Tiergeographie des Sunda-Bogens und Kontinentalverschiebungstheorie. Forsch. und Fortschr. 13, 103-4.

The archaeological sequence of Central India.

Southwestern Journ. Anthr., 9, 343-56.

Ein Beitrag zur Pithecanthropus Frage. Sitz.

Ber. Kon. Bayer Akad. Wiss., 17, 1-30. 
1911a:

1911b:

Selenka, L., and Blanckenhorn, $M$. 1911:

Smit Sibinga, G. L. 1948:

1949:

1952:

1953:

Stein Callenfels, P. V. van

1934a:

1934b:

1936a:

1936b:

1936c:

1938:

Stresemann, E. 1939:

Teilhard de Chardin, P. 1924: 1926:

1937a:
Die Flora der Trinil-Schichten. Rep. in: Selenka und Blanckenhorn.

Monographie der fossilen Flora der Pithecanthropus-Schichten. Kon. Bayer. Akad. Wiss., 6, $1-70$.

Die Pithecanthropus-Schichten auf Java. Geologische und Palaeontologische Ergebnisse der Trinil-Expedition (1907-8). Leipzig.

The Plio- Pleistocene Boundary and Glacial Chronology based on Eustasy in the East Indies Rep. 18th Session, Intern. Geol. Congr., 9, 97-98.

Pleistocene Eustasy and Glacial Chronology in Java and Sumatra. Verhand. Ned. Geol.-Mijnbouwk. Gen., 15, 1-31.

Interference of Glacial Eustasy with Crustal Movement and Rythmic sedimentation in Java and Sumatra. Geologie en Mijnbouw, 6, 220-25. Pleistocene Eustasy and Glacial Chronology in Borneo. Geologie en Mijnbouw, 11, 365-83.

Korte Gids voor de Praehistorische Verzameling. Jaarboek Kon. Bat. Gen. voor K. en W., 2, 1-36.

Implements used by Solo Man. Ill. London News, 254.

L'industrie osseuse de Ngandong. L'Anthropologie, 46, 359-62.

New and unexpected light on the Java Ape Man: Fossil Animal bones found which help in determining his period. Ill. London News, 624.

Recent discoveries of skulls and Pleistocene Stone Implements in Java. Man, 36, 209-10. Miscellaneous notes on the Prehistory of SouthEast Asia; the Palaeoliths from Java. Proc. 3rd. Congr. of Prehistorians of the Far East, 96-9.

Die Vögel von Celebes. Journ. f. Ornithologie, 87, 312-425.

Le Paléolithique en Chine. L'Anthropologie, 33, $630-31$.

Fossil Man in China and Mongolia. Natural History, 26, 238-45.

The Pleistocene of China: Stratigraphy and Correlations. In: Early Man, ed. by G. G. Mac Curdy, 211-20. 
1937b:

1938:

1950:

Teilhard de Chardin, P. and Pei, W. C. 315-58

Terra, H. de 1943a:

1943b:

Terra, H. de and Paterson, T. T. 1939:

Tweedie, M. W. F. 1942:

1953:

1955:

Umbgrove, J. H. P. 1949:

Vallois, H. V. 1935:

Vaufrey, R. 1950:

Weidenreich, $\mathbf{F}$. 1942:

1943:

1944:

1945:

1946:

1954:

Wetmore, A. 1940:
Notes sur la Paléontologie Humaine en Asie Méridionale. L'Anthropologie, 47, 23-33. Deuxièmes notes sur la Paléontologie Humaine en Asie Méridionale. L'Anthropologie, 49, 251-52.

Le Paléolithique du Siam. L'Anthropologie, 54, 547-48.

The lithic Industry of the Sinanthropus Deposits in Choukoutien. Bull. Geol. Soc. China, 11, 315-58.

The Pleistocene of Burma. Trans. Am. Phil. Soc. 32, 271-339.

Pleistocene Geology and Early Man in Java. Ibid, 437-64.

Studies on the Ice Age in India and associated human cultures. Carnegie Inst. of Wash., 493, $1-354$.

Prehistory in Malaya. Journ. Royal Asiat. Soc. $1-13$.

The Stone Age in Malaya. Journ. Mal. Branch, RAS, 26, 1-90.

Prehistoric Malaya. Background to Malaya

Series 6, 1-43.

Structural History of the East Indies.

Cambridge.

Le Javanthropus. L'Anthropologie, 45, 71-84.

Un gisement paléolithique à Celèbes. L'Anthropologie, 54, 173.

Early Man in Indonesia. Far Eastern Quarternary, 2, 55-56.

The skull of Sinanthropus pekinensis. Palaeontologica Sinica, 10, 1-484.

Giant Early Man from Java and South China. Anthr. Papers Am. Mus. Nat. Hist., 40, 5-134. The puzzle of Pithecanthropus. Science and Scientists in the Neth. Indies. New York, $380-90$.

Apes, Giants and Man. The University of Chicago.

Morphology of Solo Man. Anthr. Papers Am. Mus. Nat. History, 43, 5-134.

Avian remains from the Pleistocene of Central Java. Journ. Palaeont., 14, 447-50. 


\section{MESOLITHIC}

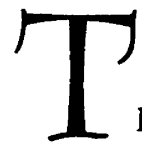

INTRODUCTION. plex since volcanic activity and uplift are likely to have continued after the last retreat of the ice in Northern Europe. A general rise in sea-level occurred in South-East Asia during this period and communications with the Continent of Asia must have become more sporadic. The Asian landbridges must have become inundated, if this had not already taken place, though it is notable that at least one of the Mesolithic industries described below has direct connections with the Continent. The topography and climate of Indonesia appear to be similar to those of the present, and there is a recent fauna, though many individual species appear to have been larger than those extant to-day.

The colonization of Indonesia by different races of Sapiens took place during this period and Homo soloensis is not present. The new races have been differentiated as Australoids, Palae-Melanesoids, Veddahs and Negritos, and are presumed to have spread throughout the Archipelago by means of rafts and primitive canoes (Fig. 13). Three different industries have been recognized and are described below. They are respectively the Hoabinhian Pebble Tool Industry, the Sampung Bone Culture, and the Toalean and allied flake and blade industries.

\section{THE HOABINHIAN PEBBLE INDUSTRY.}

The Hoabinhian Industry of Indonesia is confined to Sumatra, though certain discoveries in Java and Celebes have been ascribed to Hoabinhian influence and will be briefly mentioned in this section. The industry is native to Indo-China and Peninsular Malaya where it is found in numerous cave sites in the interior, normally in association with shell middens formed at the mouth of these caves. Coastal middens associated with some Hoabinhian tools have been found in Province Wellesley, Malaya, where they are believed to represent a late industrial stage. 80

80 Earl; $1860 ; 119-29$. According to Huxley; 1863, 265-66, the human remains excavated by Earl in the Province Wellesley shell mounds, display Australoid and Melanesian characteristics.

Mijsberg; 1940, 100-18. The skeletal remains found by Van Stein Callen- 


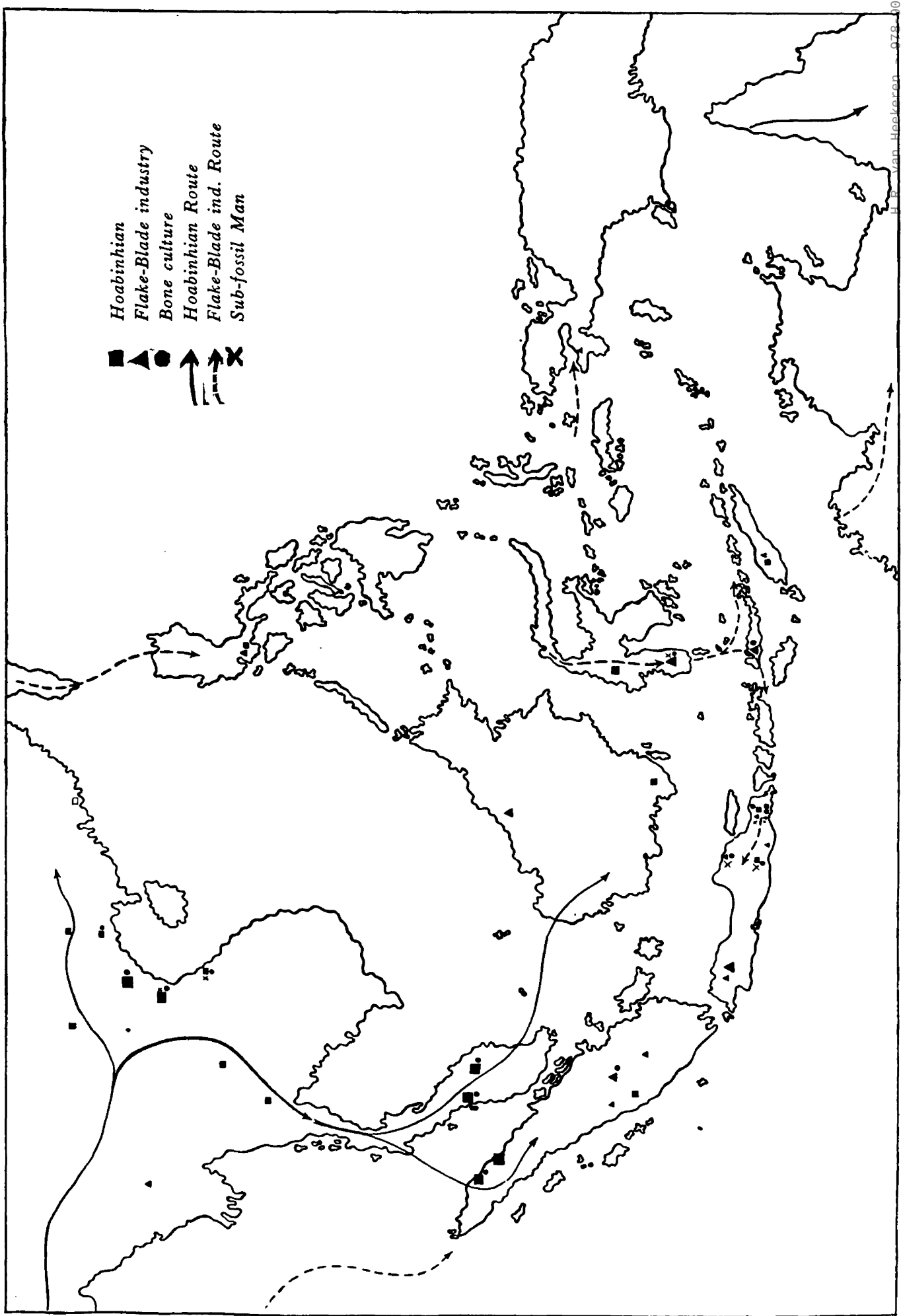


In Sumatra the distribution of the Hoabinhian is confined to the coastal region facing the Malay Peninsula, where it is represented by extensive middens (East Coast Sumatra and Langsar) and large surface stations (Atcheh and North Coast Sumatra). The principal tool type forming $90 \%$ of the industry is an elongate oval unifacial pebble known as the 'Sumatralith' to previous investigators. (Pl. 20, 21).

Unifacial pebble-tools of many different types are known from the Hoabinhian collections in Malaya and Indo-China 81 but it seems likely that the 'Sumatralith' is an Indonesian development, and it is certain that no industries from the Peninsula or Asian sites show a dominant percentage of unifacial tools like those found on the coastal sites of Sumatra.

fels in shell heaps in the same province show definite traces of burial; the parts - a face part and a mandible - were well covered with ruddle. The mandible in question was studied by Mijsberg who points out that it resembles in every detail the lower jaw of recent Palae-Melanesians.

81 Tweedie; '53, 10-18. "The Hoabinhian is the only one of the Mesolithic cultures that is extensively developed in Malaya. The associated fauna is of recent date since all the species are members of the existing fauna. Occasionally flexed burials are discovered (Gol Ba'it, Sungei Siput, and Gua Kerbau)".

Tweedie; '55, 2-5. "From some time after 10.000 years ago until about 4.000 years ago, Malaya was inhabited by a race of men having physical characters suggesting affinity with the present day Melanesians. They lived in caves and rock-shelters and were hunters and food-gatherers, and possibly cannibals. They cooked their food at fires in the caves and sometimes buried their dead in the floors of their dwelling places. They made rather rough, but quite easily recognisable, stone tools by chipping a river pebble to produce a jagged cutting - or scraping - edge all around it; sometimes the end of the tool was ground to make an edge. They collected iron oxide or Haematite, a soft red stone and ground it to a powder, probably to make a kind of red paint to simulate blood for ritual purposes".

Snell; '49, 1-25. Snell studied two skulls from Gol Ba'it, Sungei Siput and found that the skulls in question belong to the Melanesian racial group.

Colani; '27, '30, 299-422.

Starting excavations in 1906, E. Patte and H. Mansuy discovered the so-called Bacson-Hoabinhian Culture in 37 caves in the Bacson Massif, north of Tonkin. There were numerous 'Sumatraliths', crude scrapers and unworked pounding stones; furthermore pebbles with ground cutting-edges. These tools were named Proto-neoliths. All layers contained gravel stones, mostly of slate with two parallel grooves which served as grinding stones.

South of Tonkin, separated by a delta, $120 \mathrm{kms}$. wide, lies the massif of Hoabinh where Madeleine Colani examined a great number of caves. The 'Sumatraliths' here were generally fashioned of oval or more or less flat pebbles. Semi-circular or ellipsoid stone axes with straight cut butt-ends were named 'short-axes'. Bifacial axes were mainly found in the middle layers of the cave deposits.

Human skeletons belonged to three different races: Australoids, Palae-Melanesians and Mongoloids. The Palae-Melanesians are predominant. 
Sumatra.

The first Hoabinhian biface was found in 1924 by Neumann at Batu Kemang, Deli and Serdang District on the East Coast of Sumatra. Subsequent research showed that the implement was not found in situ. This biface is made of weathered andesite and flaked from both faces giving it a characteristic wavy or zig-zag profile. It has a typical almondshape, part of the point being broken off, and measures $151 / 2 \mathrm{~cm}$. long and $7 \mathrm{~cm}$. wide. ( $\mathrm{Pl} .18$ ). The attribution of this tool to the Post-Glacial period was confirmed by the subsequent discovery of an identical tool during the excavation of a kitchen midden at Medan, Sumatra.82

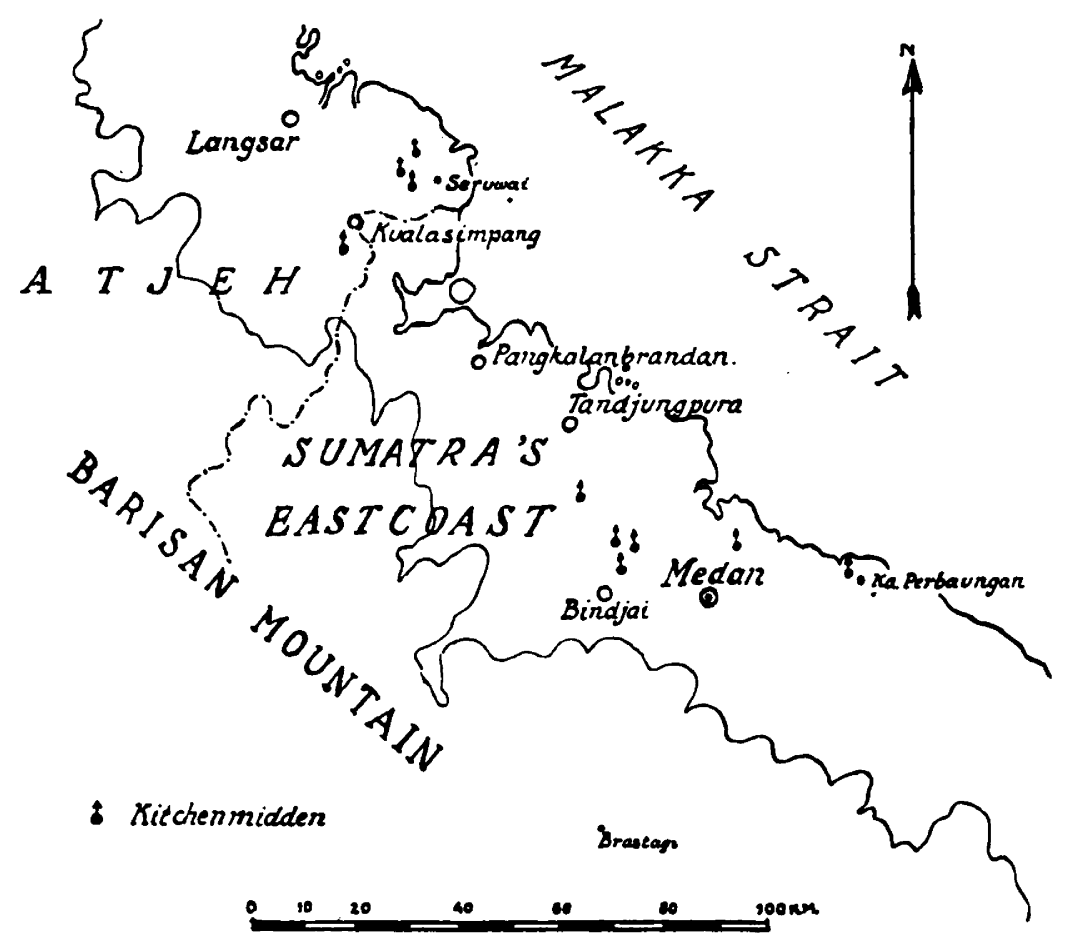

Fig. 14.

Large shell mounds were reported near Seruwai, East Sumatra, on the lower course of the Tamiang River in 1917.83 These mounds were

82 Van Stein Callenfels; '24, 127-33.

s3 Yearbook 1917 of the Mining Department at Bandung. 
30 metres in diameter and 4 metres high. In the opinion of the discoverers they had been formed by a plague raging among the shell fish. Witkamp ${ }^{84}$ was later able to show that their presence was due to human activity. The distribution of these middens has since been found to extend along the North East Coast for approximately $130 \mathrm{kms}$. and all these sites are now about 10 to $15 \mathrm{kms}$. inland (Fig. 14). These middens are believed to have been formed on an old strand line isolated inland by a subsequent isostatic emergence of the ground and some of these have been submerged more than a metre in the swamps formed behind the present beach.

Excavations have been carried out by van Stein Callenfels near Medan, East Sumatra, and by Schürmann in Atcheh.85 The former excavated a site on the Saentis Estate northeast of Medan (Pl. 19; 21). No report was published and the following information has been extracted from his field notebooks. 86 The shell mound contained $92 \%$ Meretrix meretrix L. and $6.5 \%$ of Ostrea shell according to this source. A number of worked stone implements were recovered from a matrix of marine shells in situ. These were all unifacial Hoabinhian tools of the common Sumatran type, with the exception of one broken bifacial tool of the type known as hache courte (or short-axe) in Indo-China (Pl. 20 nr. 922). Crude pestles and mortars of Hoabinhian type and a large quantity of Haematite were also found during the excavations.

A further description of these middens can be obtained from the excavations of a shell mound at Bindjai-Tamiang, Atcheh by Schürmann. This site lies about $15 \mathrm{kms}$. inland and is 10 metres above the present sea-level. The upper portion of the midden has been removed for economic purposes and the excavation was confined to the eastern central portion of the remaining mound. The midden appears to have been excavated in spits of even size and the stratigraphy was recorded from top to bottom in the following manner:

$30 \mathrm{~cm}$. shells mainly Meretrix.

$30 \mathrm{~cm}$. Ash layers with Haematite, pebbles, artifacts and bones.

$20 \mathrm{~cm}$. Shells mainly Meretrix.

$20 \mathrm{~cm}$. Ash layer containing Haematite and bones.

$20 \mathrm{~cm}$. Shells mainly Meretrix.

54 Witkamp; '20, 572-74.

85 Schürmann; '31, 905-23.

86 Also from an illustrated article in one of the numbers of the Illustrated London News. 
$10 \mathrm{~cm}$. Ash layer containing Haematite, pebbles, artifacts and bones.

$60 \mathrm{~cm}$. Sand, shells (Meretrix), pebbles, a few bones, wood.

$50 \mathrm{~cm}$. Greyish-blue to yellow marine clay without shells.

$100 \mathrm{~cm}$. Yellow clay and sand without shells.

Schürmann records that the Artifact bearing layers dipped $10^{\circ}$ eastwards. This shows that the ash layers were nearly horizontal, and probably represent true hearth deposits. The lowest layers of the shell mound were continued in a natural depression below sea-level. Oysters and Algae adhered to the flaked surface of some tools showing that these had been submerged.

Human skeletal material recovered from this excavation included a cranium, with occiput and temporal bones, fragments from three other skulls and about 30 fragments of limb bones and other bones. Several of the human limb bones had been split, evidently to remove the marrow, which suggests that cannibalism was practised by these groups of Hoabinhians. The cranium has a slight browridge, and the human remains were interpreted as short of stature, dolichocephalic and belonging to a Melanesian racial group. 87

The fauna from this site included:

1. Midden shells. Besides Meretrix meretrix L. there were Ostrea virginica Gmelin, Placuna placenta Linné, Arca (Scapharca) granosa Linné, Cyraena cf. coazans Gmelin, Conus (Dendroconus) figulinus Linné.

2. Bivalve Molluscs and Gastropods showing possible marks of utilization.

3. Fishes, crabs and tortoises.

4. Vertebrates of recent type including Elephant, Deer and Bear.

The tools recovered from the excavation are manufactured from stone pebbles, presumed to be of local origin, including andesite, liparite, quartzite, quartz, chert and sandstone.

Mühlhofer 88 divides these unifacial tools into three groups in order of importance:

1. Large broad unifacial tools; $12.5 \times 8.5 \mathrm{~cm}$. and $5 \mathrm{~cm}$. thick.

2. Large narrow unifacial tools of similar length.

3. Small unifacial tools; $9.5 \times 7.5 \mathrm{~cm}$. and $4 \mathrm{~cm}$. thick.

Further surface finds in Sumatra may be briefly summarized:

S7 Wastl; '39, 181-85.

s8 Mühlhofer; '38, 30-34. Küpper; '30, 318-25. 
Heyting (1927) reports the discovery of crude stone axes of the unifacial 'Sumatralith' type in the Upper Serdang region. One of the implements, almond-shaped, measured $13 \times 9.3 \mathrm{~cm}$. and was $4.2 \mathrm{~cm}$. thick. H. Küpper describes a number of similar sites on the North Coast of Sumatra and the Langsar region of Atcheh, Lho' Seumaweh being the most prolific. The region where these sites were discovered is one geographical unit characterised by a range of barren limestone ridges covered in some parts by a thin layer of quarternary gravels, which contain the raw materials used in the manufacture of the industry. Practically all the implements, and there are thousands of them, can be classified as 'Sumatraliths'. They are manufactured of pebbles, mostly of a fine-grained quartzite. Lebzelter has described the collection in some detail. ${ }^{89} \mathrm{He}$ finds that the industry can be divided into oval, disc-shaped and elongated pick-like pebble tools, flakes from pebbles, and broad facetted flakes. The majority of the first class are unifaces of the Hoabinhian Sumatra type. Lebzelter has divided the industry into the following types:

1. Triangular, pointed monofacial tools. No marginal retouches. Measurements: 84 × $85 \times 45 \mathrm{~mm}$., $88 \times 86 \times 45 \mathrm{~mm}$., 104 x $60 \times 46 \mathrm{~mm}$.

2. 'Asturiashauer'. Both point and butt-end retouched. The upper face slightly convex, the under surface unworked, and flat. These artifacts as well as the ones mentioned under 1. were used to strike the shells off the shell-banks and had therefore to be large and heavy. Measurements: $134 \times 74 \times 53 \mathrm{~mm}$., $138 \times 70 \times 35 \mathrm{~mm}$., $90 \times 66 \times 28 \mathrm{~mm}$.

3. Disc-shaped scrapers made by crudely flaking the more or less round pebbles. The unflaked under surface is always slightly convex with marginal retouches. Measurements: $100 \times 82 \times 29$ mm., $86 \times 62 \times 32$ mm., $94 \times 78 \times 40 \mathrm{~mm}$.

4. Flat disc-shaped scrapers, fashioned from flakes. The under surface slightly convex, the upper surface chipped. The edges are alternatively flaked.

5. Tabular scrapers; large, thin manufacts with one, sometimes both surfaces flaked. Measurements: $92 \times 76 \times 37 \mathrm{~mm} ., 114 \times 75 \times 30 \mathrm{~mm}$., $85 \times 75 \times 30 \mathrm{~mm}$.

6. High-backed core-scrapers. The under surface has sometimes concavities or notches at the point. They are supposed to have been used for the straightening of spear and arrow shafts. Measurements: $70 \times 60 \times 40 \mathrm{~mm}$., $80 \times 47 \times 27 \mathrm{~mm}$.

88 Lebzelter; '35, 318-25. 
7. Core-sidescrapers. The under surface convex. Retouching along one edge only. On the upper surface shallow facet-flaking. Measurements: $134 \times 60 \times 50 \mathrm{~mm}$.

8. Monofacial pebbles. They are of a great frequency and typical for this stone culture. There are small pieces among them. Mostly oval-shaped, their upper surface usually displays marginal retouches. Measurements: 63 × $43 \times 12 \mathrm{~mm}$., $66 \times 37$ x $18 \mathrm{~mm}$., $90 \times 53 \times 27 \mathrm{~mm}$.

9 Bifacial hand-axes, mostly large-sized, measuring $95 \times 25 \mathrm{~mm}$., $61 \times 21 \mathrm{~mm}$. or $72 \times 26 \mathrm{~mm}$. Both under and upper surface show longitudinal flaking.

10. An unique type of the bifacial axe showing traces of polishing.

11. Pick-like scrapers with flat under surface and steep retouched point. Measurements: $87 \times 44 \times 30 \mathrm{~mm}$., $68 \times 36 \times 22 \mathrm{~mm}$.

From the above it will have become clear that on the East Coast of Sumatra once flourished a vigorous Mesolithic Pebble Culture, the remains of which have come to us from shell mounds and open-air sites on the flat ridges of limestone hills. It is very striking, therefore, that this form of culture is so rare in other parts of the Archipelago, and that up till now there is no report of kitchen middens along the shores elsewhere. It is obvious that there is only little information concerning their distribution. (Fig. 14).

The stone tools which have been collected by J. Bosscha during the excavation on a hill at Sakang, Western Borneo, were described by van Stein Callenfels as pebble-tools, but the examples the present author has examined in the Djakarta museum look more like unfinished neoliths. In Java this Pebble Culture is obviously secondary and in my opinion it is a late offshoot of the Hoabinhian which has penetrated the Sampung Bone Culture which will be described in the next paragraph.

In the Gua Lawa this culture is represented by pestles and mortars; in the Betpuruh Cave near Pradjekan by pounding stones with gripmarks and rubbing stones; in the Sodong Cave by a few primitive 'shortaxes' and small Sumatraliths, in the Mardjan Cave by a number of 'short-axes' and a single rectangular scraper. All these caves and rockshelters are situated in East Java. These faint traces of the Hoabinhian in Java are always associated with a bone industry, displaying bone spatulae of two kinds, awls and digging tools and daggers of antler, and besides red Haematite, human skeletal remains of a megalodont race with Papua-Melanesian and Veddoid affinities.90 
P. V. van Stein Callenfels, in view of a Palae-Melanesian skull which was found associated with the Hoabinhian in Eastern Sumatra and of reports from Malaya and Indo-China, even went so far as to speak of a "Melanesian Civilization" with regard to the Hoabinhian. Collings, 91 MacCarthy 92 and Evans, 93 however, are definitely opposed to this qualification which they consider as premature at the least.

In some places in Australia 'Sumatraliths' are still in use and reveal to us that, at least in this area, such tools are attached to a forked wooden haft, which makes it highly probable that they have been used in the very same way in other regions during prehistoric times. Therefore the term 'hand-axe' which is sometimes used, should be understood only in a technical sense, viz. that of core-implement in view of the fact that in this case the core is the pebble. As regards their technical workmanship and variety of types, the tools of the Hoabinhian are relatively poor.

\section{THE SAMPUNG BONE INDUSTRY.}

In January 1926, L. J. C. van Es, the geologist, visited the Southern Mountains near Ponorogo, East Java. On this occasion he was informed that employees of the sugar factory Patogan during World War I had obtained phosphates from the Lawa Cave near Sampung and in the course of this had encountered animal bones. As there was a chance that they were fossil vertebrates, van Es sent an assistant to this cave with instructions to collect fresh material. The bones then obtained were forwarded to Bandung for examination. They had not become fossilized, but apparently belonged to animal species which still exist in Indonesia. Several bones, however, appeared to have been worked and artificially polished. It was decided to perform a preliminary excavation in the northeastern part of the cave. The deposit was dug away to the rock-bottom and proved to consist of the following layers: immediately covering the bottom, a layer of brown sand, $4 \mathrm{~m}$. thick, containing small pebbles of fluvial origin; upon this a stratum of volcanic ash and sand, approximately $75 \mathrm{~cm}$. thick; next a sediment, $41 / 2 \mathrm{~m}$. thick, consisting

01 Collings; 38a, 122-23.

92 MacCarthy; 40a, 38.

93 Evans; '38, 141-46. Von Koenigswald; 52, 96-98.

According to some scientists, large teeth are no racial characteristics, but the fact stands that Javanese caves yielded nearly exclusively human remains with exceptionally large teeth, in contrast with the Celebes caves which produced human teeth of normal or small size. This phenomenon will strike anyone who has occupied himself with the excavation of caves both in Java and in Celebes. 
of sand and mud, and containing algae. The sediments has most probably been deposited in a pool or small lake which had afterwards become completely silted up. Only after this place the cave had been inhabited by men, who used it as a home and shelter. These men were no Indonesians as yet, as we will see presently.

In some places the cultural layer was more than $3 \mathrm{~m}$. thick, a phenomenon never seen before or since in Java. It yielded several cultural elements such as a few neolithic polished adzes, a large amount of implements manufactured of bone and antler, and a number of bifacial stone arrow-heads with concave-shaped butt-ends. There was no difference between the stratigraphy of the various elements. ${ }^{94}$ Van Es discovered a human skeleton in situ, lying on its left side, the legs bent, the head resting on the left shoulder and the right hand upon the face.

From 1928 to 1931 systematic excavations were undertaken by van Stein Callenfels. The artifact-bearing deposits were more than $3 \mathrm{~m}$. thick and offered a good opportunity to obtain a stratigraphical view of the various cultural elements. 95 Van Stein Callenfels stated that in the upper, youngest layers a few iron and bronze objects had been found with some Neolithic Quadrangular Adzes and some pestles and mortars. The next layer contained exclusively implements fashioned of bone and antler, such as awls, daggers, fishing hooks and sticks for digging up edible yams and roots. Furthermore, there was quite a number of two kinds of spatulas, the first of the concave-convex type made of a long bone, split lengthwise and polished to a round cutting-edge. The second type is made of a flat oblong polished bone with a rounded cutting-edge, in fact the scraper used for cleaning and scraping of tubers and roots (Pl. 23; Fig. 15). The third layer yielded Neolithic, bifacial arrow-heads with concave but-ends; among these were a few very small pieces probably used for fowling. No potsherds occurred in the central stratum, the third layer on the other hand produced some fragments of cord marked pottery. In my opinion, this stratigraphy is far from convincing.

During the excavation, several human skeletons were found; some of them not complete. Among these was the skeleton of a child showing the cutting of the milk-teeth. Round the neck was a necklace of perforated shells, apparently used as a funerary gift. One of the shells proved to be a Nerita chameleon L., the others Naticae. Similar perforated shells

94 Van Es; '26, 468. 74. '29, 329-40.

95 It is therefore all the more regrettable that the method of projection for the drawing in of finds (this being done by projecting them on two or three assumed planes) has not proved very suitable for the purpose. 

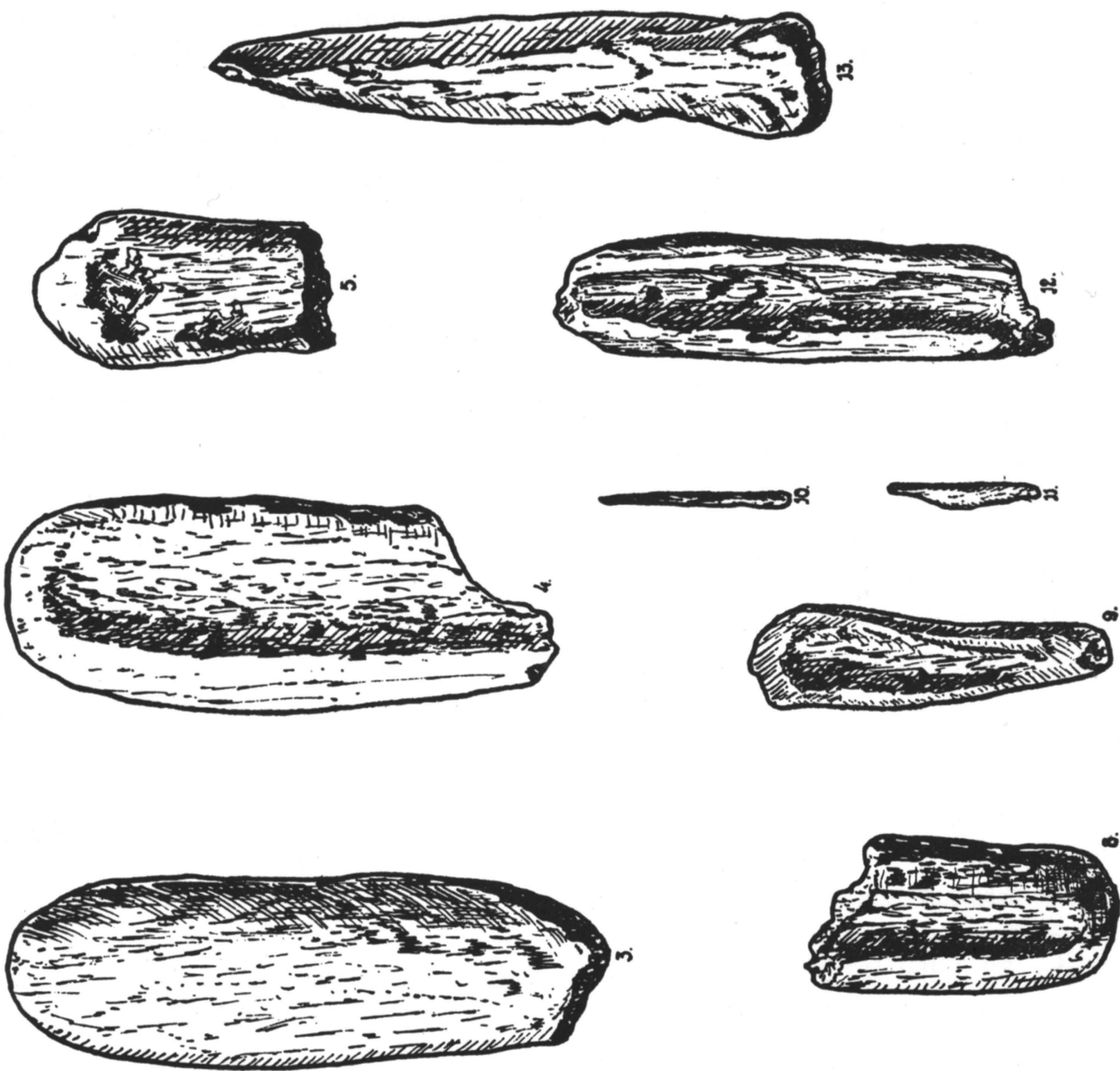

సْత

己ั
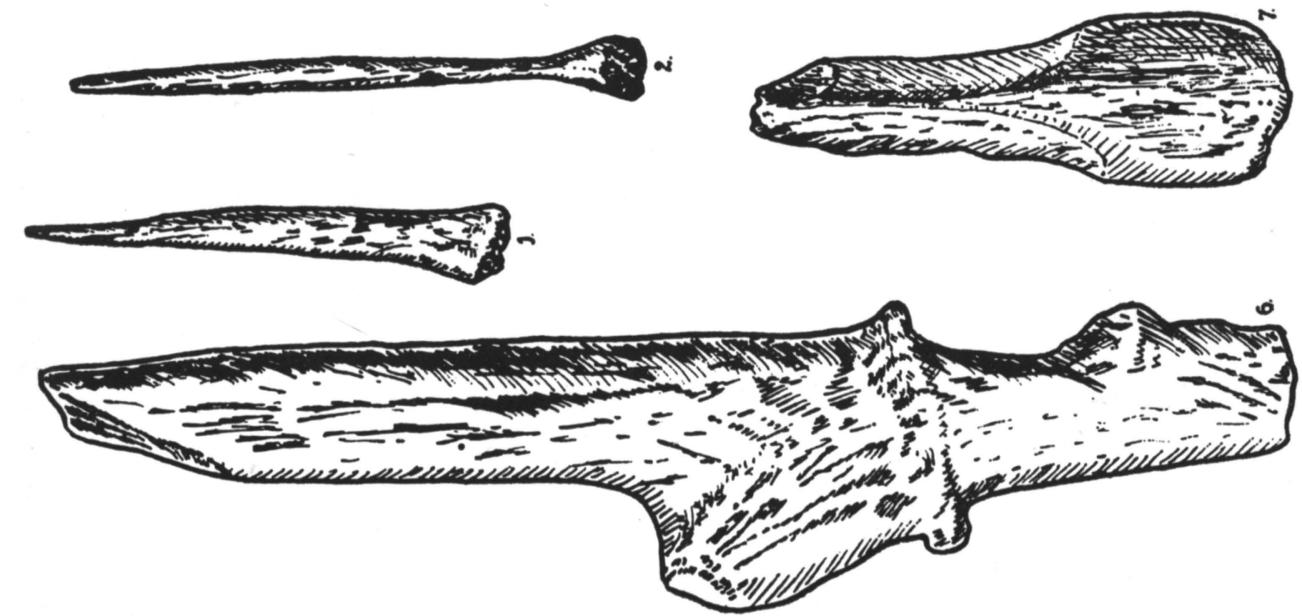
have afterwards been found scattered in the cultural layers; among these were larger shells such as Natica mamila L. There were other ornaments, too: perforated teeth of carnivores (Paradoxurus hermaphrodites), two small perforated plates of mother-of-pearl, four fragments of an amulet made of bone and showing traces of incised concentric squares near the edge, and many pieces of ruddle.96

Several skeletons of adults were dug up, but they were in no condition to be reconstructed. More than once a skeleton had been covered by a rock to keep away the animals or to prevent the deceased's spirit from leaving the body. (Pl. 24).

The skeletal material was forwarded to W. A. Mijsberg, who has been able to reconstruct one of the skulls ( $\mathrm{Pl}$. 25a, b). It has been measured accurately and described.97 Besides, various teeth from the cave in question and from other caves near Bodjonegoro where a similar culture was encountered afterwards, have also been examined. The examination of the Sampung skull disclosed the following indices:

A. Cranial Breadth $\times 100$

78.2 (mesocephalic)

Cranial Length

B. Auricular-Bregma Height x 100

Cranial Length

C. Auricular-Bregma Height x 100

Cranial Breadth

88.0 larger than minima of Javanese.

D. Minimum Frontal Diameter x 100

Cranial Breadth

68.4

E. Total Facial Heigth $\times 100$

Bizygomatic Diameter

45.5 smaller than minima of Javanese.

F. Orbital Height $\times 100$

Orbital Breadth

72.1 smaller than minima of Javanese.

o6 Van Stein Callenfels; '31, 16-32. Dammerman; '34, 229-35.

97 Mijsberg; '32, 39-54. 
G. Nasal Breadth x 100

Nasal Height

H. Bizygomatic Diameter $\times 100$ 100.8

Maximum Cranial Breadth

I. Minimum Frontal Diameter $\mathbf{x} 100$

Maximum Bizygomatic Diameter

Of the teeth we only give the measurements that are larger than the maxima of the Javanese:

The third left lower molar with a length of 13.0 and breadth of $12.5 \mathrm{~mm}$. The first right upper molar with a length of 12.8 and breadth of $13.4 \mathrm{~mm}$. The first left upper molar with a length of 12.3 and breadth of $13.1 \mathrm{~mm}$. All these molars are from the Bodjonegoro Caves.

From the Sampung Cave came a first right lower molar with a length of $13.1 \mathrm{~mm}$. and a first left lower molar with the same length.

Mijsberg has pointed out that the Sampung skull is higher vaulted than the average Javanese skull and he concluded from the stronglybuilt teeth which surpass the maxima of the Javanese more than once, that they do not belong to Javanese, but to a megalodontic race, resulting from the interbreeding of Papua-Melanesian and Australian races.

The animal remains were sent to $\mathrm{K}$. W. Dammerman 98 for examination and they belong to the species mentioned below:

UNGALATA:

Bos (Bibos) banteng Raffl.

Bos (Bubalus) bubalis L.

Cervus hippelaphus Cuv.

Cervus eldi.

Muntiacus muntjak Zimm.

Sus vittatus Temm.

Elephas maximus $\mathrm{L}$.
Rhinoceros sondaicus Desm.

Tragulus kanchil Raffl.

\section{PRIMATES:}

Macaca irus Cuv.

Pithecus pyrrhus Horsf.

Nycticebus coucang Bodd.

Dammerman; '32, 30-31. 
CARNIVORA:

Felis bengalensis Kerr.

Neofelis nebulosa.

Paradoxurus hermaphrodites Pall.

Cuon javanicus Desm.

Lutra cinerea Ill.
RODENTIA:

Hystrix javanica Cuv.

Petaurista petaurista Pall.

Ratufa bicolor Sp.

Among this sub-recent Indo-Malayan fauna Elephas maximus, Bos bubalis, Neofelis nebulosa and Cervus eldi are extinct in Java. Rhinoceros still exists in the westernmost part of Java. Bone and antlers had been used for the manufacture of implements, teeth of carnivores had sometimes been perforated in order to serve as magical decoration.

Van Es also discovered a similar culture about $100 \mathrm{~km}$. north of Sampung in the Northern Limestone Hills near Bodjonegoro. The cultural deposits were not so thick as those in the Sampung Cave. Van Stein Callenfels afterwards performed excavations in three caves in this area, but only two, the Kramat and the Lawang Cave near Dander have been reported on.99 Neolithic adzes were not found here, only two kinds of bone spatulas like in the Sampung Cave and the bifacial hammerdressed stone arrow-heads. Among these very small pieces occurred also here. The deposit of the two caves was too thin to be stratified; finds of varied type were mixed together.

W. J. A. Willems visited the hills in the Semanding district in the neighbourhood of Tuban and examined two caves, the Gedeh and the Kandang Cave (1938). The first cave is $20 \mathrm{~m}$. long and the finds occurred from the entrance up to a point deep in the interior. Furthermore, preliminary excavations have been performed in the Ketjil, Bale, Pawon, Bagong, Peturon, Butol and Pangang Caves, caves and rock-shelters, all of which are situated in the same mountain ridge extending southwest to northeast near Tuban. They yielded the same prehistoric stone and bone objects as those at Sampung and Bodjonegoro; two kinds of bone spatulas (Pl. 26a) and bifacial stone arrow-heads. However, Willems reported the presence of great numbers of shell artifacts, in particular of arched scrapers with fine marginal retouches. Due to his sudden departure to Europe and the outbreak of World War II, Willems unfortunately did not have the opportunity to work out his notes. In the Annual Report 1938 of the Archaeological Service in the Netherlands Indies, mention has been made of his findings: "Unfortunately the ex-

99 Van Stein Callenfels; '31, 25-26. 
plorations have not been wholly satisfactory in that it has not been possible to gain a true insight into the stratigraphy of these cave deposits. Variation in the ground profile showed up only in places where a kind of stratum could be established by means of a sediment of phosphate and other compounds. Since no humus formation takes place in such caves and rock-shelters, it stands to reason that methods other than those used in Europe have to be followed. As regards the cultural stratigraphy, all artifacts of bone, stone and shell were intermingled in the upper and the lower layers. No more than in the Celebes caves were there separate horizons like the ones van Stein Callenfels thought to have discovered in the Sampung Cave. The shell artifacts were in the majority". The present author recently examined these finds and found that the stone arrow-heads had not always been chipped on both surfaces and that there are unifacial arrow-heads among them. Furthermore, some of the bone spatulas and daggers differ from the Sampung ones in that they display the condyle. Finally I discovered many stone implements among these which belong to the 'Flake and Blade'-category.

More than $200 \mathrm{~km}$. east of the above-mentioned caves, the present writer found traces of the Sampung bone industry in three different places in Besuki. In the spring of 1933 the Betpuruh Cave was discovered during an exploration of an isolated limestone massif in the Beser Mountains, north of Pradjekan. The outermost chamber, only illuminated by some diffuse light, was excavated, but no finds were made except near the entrance and in the adjoining small rock-shelter. The deposit on the rock-bottom was very thin and nowhere exceeded one metre. Five concave-convex spatulas have been found, quite identical with those of Sampung. There were also small and narrower spatulas, bone awls, a flat spear-head of polished antler and a small point of animal tooth. Associated with the bone industry were some elements of the Hoabinhian Culture such as pounding stones with gripmarks, some stone flake implements and one stone arrow-head with convex butt-end. The only ornament to be discovered was a small ring of mother-of-pearl.100

In the westernmost part of the rock-shelter, approximately one metre from the upright wall, beneath an overhanging ledge of rock, quite on the rock-bottom were various sub-fossil human remains. The root system of a tree growing in the vicinity had penetrated and disturbed the deposition in the whole area. Among the skeletal remains was a skull from which the following parts have been recovered:

100 See: 'Oudheidkundig Verslag' 38. Van Heekeren; '35, 123-29. 
1. Fragment of the frontal bone with glabella and an adjoining part of the upper rim of the right orbit. Attached to it was a small fragment of the right wall of the brain-case;

2. A small fragment of the frontal bone with the lateral portion of the upper rim of the left orbit;

3. The foremost part (about half of it) of the left parietal bone;

4. A fragment of the lower border of the left orbit with the greater part of the left nasal bone attached to it;

5. A great part of the lower wall of the right orbit; the right upper jaw bone was relatively complete and showed the canine, two premolars and three molars;

6. A mandible which lacked the upper part of the right ramus and the whole left ramus, while the angle was damaged; on the right all elements from canine to last molar were present, on the left the second and third molar;

7. Isolated first and second incisor. On the right, in the upper jaw the alveolae are visible in which perhaps the roots of these teeth were embedded;

8-11. Four small fragments of the skull cap.

Reconstruction of the skull has not been possible. Mijsberg states: "In general the fragments seem to correspond with the Sampung finds. Over the eyes is a ridge like that seen in the Sampung skull, but less well defined. This eminence is absent in Javanese skulls, on the other hand it frequently occurs in Australian skulls (it is said as much as $72 \%$ ). The Pradjekan glabella is, as a matter of fact, strongly developed; the adjoining upper rim of the right orbit to the incisura orbitalis is swollen to an arcus superciliaris. From this incisura runs the lateral and ascending border between the just-mentioned arcus and the lateral part of the upper rim of the orbit which represents no swelling. Lateral to the incisura supraorbitalis at some distance from the rim of the orbit is the extension of the arcus superciliaris. The mandible is strongly built and possesses a chin eminence. The measurements agree with those of Javanese males, but taking into account the following measurements: $a$. length of the row of the molars; b. length of the row of the molars and two premolars; $c$. breadth of the dental arch between the most external points of the molars, it appears that among the Javanese males which have thus far been examined, there is not one which in all measurements agrees with those of our fragments. So the fragment of this mandible possesses dental elements of a notable size which makes it probable that its owner 
belonged to a megalodont race. All things considered, the cranial fragments of Pradjekan disagree with those of modern Javanese, but resemble those of Sampung, and both taken together bear likeness to the skulls of Australoids, Papuas and related races".

The animal remains from Pradjekan have been forwarded to $\mathbf{G}$. $\mathbf{H}$. R. von Koenigswald. Apart from the relics of Varanus, tortoise and numerous molluscs, he mentioned the following mammals:

\section{PRIMATES:}

Pithecus pyrrhus Horsf.; fragments of two skulls.

\section{UNGALATA:}

Bos (Bibos) banteng Raffl.; teeth, tarsus, fragment of the humerus and other remains.

Bos (Bubalus) bubalis L.; milk teeth, a number of large canines, the condyle of a large femur and other fragments, dug up from the lowest layers.

Muntiacus muntjak Zimm.; fragments of the antlers, mandible, tarsi. Sus vittatus Temm.; an incisor from the mandible with transverse section typical for this pig, canines and an incisor from the maxilla.

This small fauna comprises species which, with the exception of Bos (Bubalus) bubalis L., still exist in Java, and they are mentioned also in Dammerman's list of the Sampung fauna. The state of preservation in both sites is nearly the same.

The second excavation in Besuki was started in 1931 and continued till 1935, the remaining section being excavated by Willems and the author in 1938.101 The activities took place near the South Coast at the northern border of the Watangan Limestone Mountain, east of the Puger village. Here, too, the Sampung types of spatulas and bone awls were excavated, but in association with a flake and crude blade industry of a semi-microlithic character and shell artifacts (Pl. 26b). Furthermore, there were isolated human teeth, strongly-built and resembling those from the Sampung, Pradjekan and Tuban Caves. Right on the rockbottom was the skeleton of a pygmy (Pl. 27). Finally there was an amulet of mother-of-pearl, perforated in three places. The fauna in this cave reads as follows:

101 Van Heekeren; '36, 187-93. 
UNGALATA:

Cervus hippelaphus L.

Bos (Bibos) banteng Raffl.

Bos (Bubalus) bubalis L.

Muntiacus muntjak Zimm.

Rhinoceros sondaicus Desm.

Sus vittatus Temm.
PRIMATES:

Pithecus pyrrhus Horsf.

Macaca sp.

The near-by Mardjan Cave also yielded some bone spatulas of the Sampung type besides a few primitive 'short-axes' and other rather small stone tools of Hoabinh type. Animal remains were scarce; on the other hand there occurred many human skeletal remains, but only one appeared to have been buried; it was lying on its back in eastwest direction, the head towards the east, and it was covered by three limestone rocks. The skull was fractured and lacked some parts of the facial region, but otherwise this thick-walled skull was in a relatively good condition. Its index measured 77.7, quite in agreement with that of the Sampung skull, and therefore mesocephalic. The mandible was massive and strongly-built, too, indicating that the owners must have belonged to a megalodontic race. The measurements of the teeth tallied with those of the Sampung and Dander Caves. Furthermore this small cave was littered with sub-fossil human skeletal remains like fragments of ulnae, skulls, isolated teeth and jaws. In some instances the ulnae had been split lengthwise and presented traces of burning, indicating cannibalism. This small cave has, in my opinion, never been inhabited, and was only used as a burial-place for a prominent individual. Whatever has further happened there, can only be guessed. The material from both the Sodong and Mardjan Caves was lost in wartime before an expert had the opportunity to examine them. 102

In a cave in South Celebes some bone spatulas have also been found. The Sampung Bone Culture, up till now, has been encountered on a large scale in East Java; to be exact in seventeen caves or rock-shelters. This culture mainly consists of artifacts made of bone and antler. It has produced awls, arrow-heads and spear-heads, daggers of antlers and digging tools to dig up yams and roots, and two types of spatulas both with a polished rounded cutting-edge, the first of a concave-convex shape, the second flat and sometimes tempered by fire and polished, it having been used as a scraper for the cleaning of roots and such. Bone fish-hooks are

102 Van Heekeren; '37b, 269-77. 
rare. All caves displayed a great quantity of red pigment, this having been used to smear the body and face during ceremonial festivities. The dead were interred in caves and lain down either on one side or on the back, the legs bent and the hands folded on the face. Buried with them were funerary gifts such as necklaces of perforated shells and animal teeth. Small mother-of-pearl rings and plates of the same substance, pierced in two or three places, served as ornaments or amulets. The cave-dwellers were apparently not able to make pottery. Though still living on edible molluscs and wild vegetables, they had become increasingly competent in hunting big and small game. The Sampung Bone Industry in Java was accompanied by a sub-recent Indo-Malayan fauna, a fact that definitely establishes its Post-Glacial age. 103 The position this industry occupies and the presence of northern Neolithic bifacial, hammerdressed stone arrow-heads, make it probable that this culture is younger than the Hoabinhian. In that period there were still Papua-Melanesians in Java, and there existed Elephas maximus, Neofelis nebulosa, Bos (Bubalus) bubalis and Cervus eldi, the last-named still living in Indo-China and Siam.

Beyond Java, this culture has been found in Japan, China, IndoChina and in one place in the Malay Peninsula. In the oldest layers of the artifact-bearing deposits of the caves in Indo-China this bone industry is absent. They yielded only rather primitive artifacts of bone and horn. More southwards, in the Hoabinh Province, they were met in a rather great number and variety, though they are never predominant. But a shell mound at Da-But (North Annam) displayed a bone culture which, though associated with Hoabinh implements, in many respects resembles the Sampung Industry, and what is more, produced bone implements which have not been found in Tonkin, but in Sampung. Van Stein Callenfels, therefore, is of the opinion that it originated and developed south of Tonkin and gradually superseded the use of stone, until it reached the pure form as produced by the central layer of the Sampung Gave, unaccompanied by stone implements.

103 No traces of fossil men and other fossil mammals have been encountered in caves in Indonesia. Many if not all of the caves may have been formed in Post-Glacial times. 


\section{THE FLAKE AND BLADE INDUSTRIES.}

A. The Toalean of South Western Celebes.

The well-known Swiss naturalists Fritz and Paul Sarasin were the first to discover a blade industry of a semi-microlithic and microlithic character in Indonesia during their second expedition to Celebes which lasted from March 1902 to April 1903. Twice they visited the rather isolated limestone mountain-range near Lamontjong, east of Chamba in the southern region of what was then the principality of Bone. After much trouble and privation they finally came into contact with the so-called Toale who still lived in the forests and partly dwelt in caves. The Sarasins excavated four caves near Lamontjong; during these activities they discovered a mesolithic flake culture which was essentially founded on blades. The presence of barbed and winged stone arrowheads betrayed Neolithic influences of northern origin. The caves which were excavated are known as the Tjakondo, Ulelebá and Balisao Caves. The first one, consisting of a rock-shelter and a cave, is situated between the villages of Bakunge and Lapankanru. The rock-shelter is called the Upper Tjakondo Cave. It is about $20 \mathrm{~m}$. broad and lies above a dry watercourse about $430 \mathrm{~m}$. above sea-level. Its deposit was not stratified and consisted merely of a greyish ashlayer mixed with limestone cinders in which a number of stone and bone implements were found. The prehistoric horizon was only $80 \mathrm{~cm}$. thick and passed abruptly into a sterile, yellow stone layer which ended right at the rock-bottom. At $10 \mathrm{~cm}$. below the ground-level occurred many animal bone fragments and stone and bone artifacts; the richest level reached a depth of only 10 to $40 \mathrm{~cm}$. Many of the bones appeared to be fractured and calcined. Among the artifacts were implements like blades, three single-edged and doubleedged knives, scrapers, points and numerous waste products. Moreover, stone arrow-heads and other stone flakes with serrated edges, typical for the Upper Toalean, were found. All objects had been manufactured of andesite, chalcedony or sometimes even of limestone. Then there was a ground incisor of a boar, the point of a wooden stick and a fragment of a human skull which appeared to be perforated. It had perhaps been used as a charm or worn by the relatives as a memento. But this point will be discussed presently. 104 Potsherds were found mainly in the upper layers and could not be distinguished from the Buginese earthenware; most probably pottery came to the cave-dwellers by means

104 Sarasin; '05a and b. '35, 127-33. 


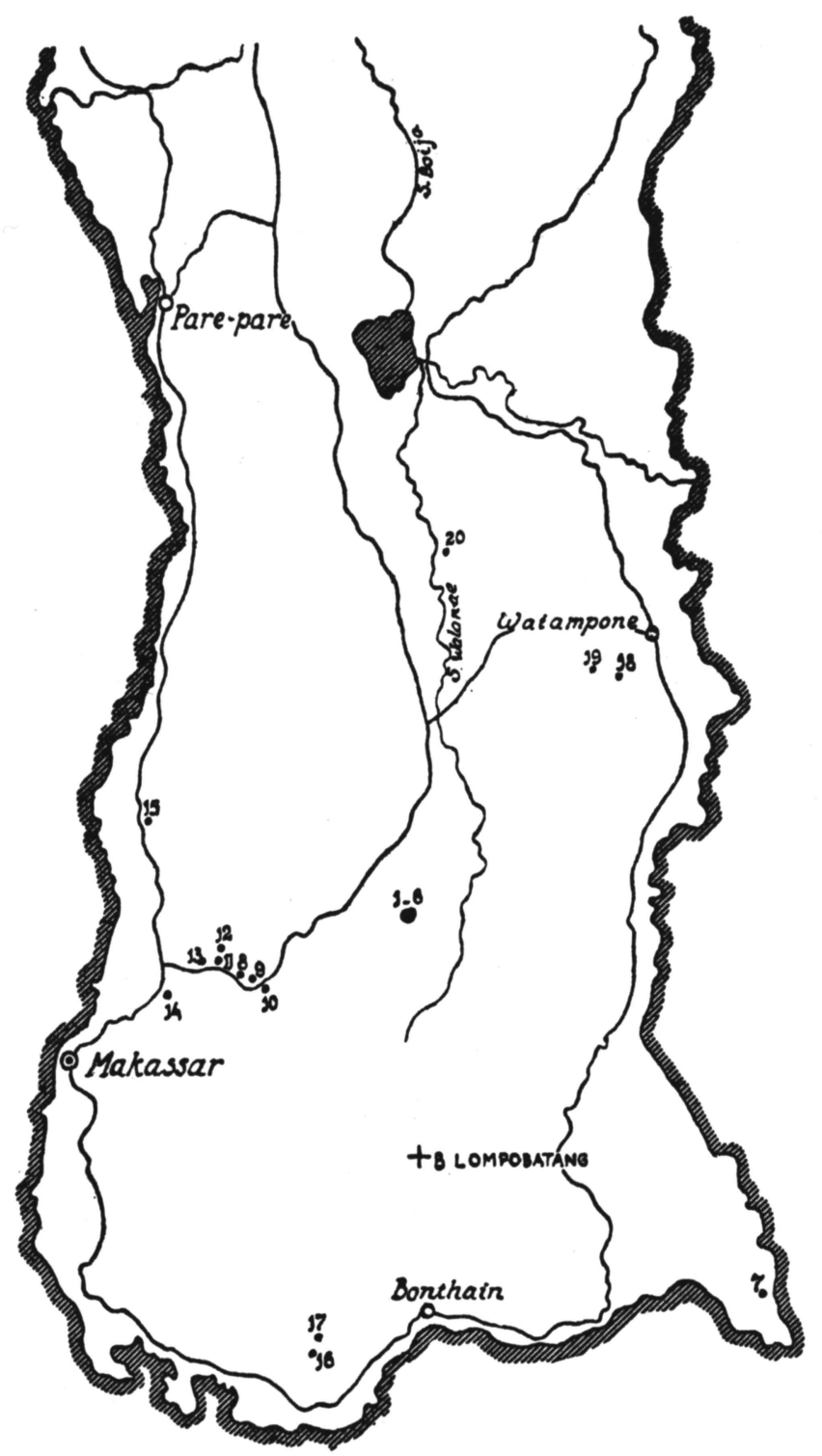

Fig. 16. Distribution of the Toalean sites in Sth. West Celebes.

1. Leang Tjakondo I

2. Leang Tjakondo II

3. Leang Uleleba

4. Leang Balisao

5. Leang Tomatue Katjitjang

6. Leang Sebang

7. Leang Ara

8. Leang DjariE

9. Leang Saripa

10. Leang Karassa'
11. Leang Burung

12. Leang PattaE

13. Leang Lampoa

14. Mandai

15. Leang Panameanreanga

16. Batu Edjaya

17. Panganreang Tudea

18. Bola Batu

19. Panisi Tu'buttu

20. Leang Tjadang 
of barter in later times. There were no traces of domestic animals, except a dog's tooth.

In the second or Lower Tjakondo Cave the $40 \mathrm{~cm}$. thick ashlayer contained many stone blades, double-edged knives, pedunculated scrapers, arrow-heads and a few animal remains. There were also the charred remains of a crudely knotted sack.

The Ulelebá Cave yielded artifacts and the remains of two human individuals which were rather fragmentary. They comprised twelve cranial fragments, a fragment of the right part of a maxilla with two premolars, five isolated molars, four milk teeth and one incisor. These fragments belong partly to an old male adult and partly to a young individual. There was also a comparatively intact humerus which pointed to a race of small stature with some primitive characteristics.

The Balisao Gave contained an ashlayer of 40 to $45 \mathrm{~cm}$. thickness, which yielded stone artifacts, animal bones and some potsherds. It covered a barren yellow, stony layer.

The mammal remains from these caves indicate a fauna which still exists in Celebes, establishing therefore a Post-Glacial age.105

The same area was visited by van Stein Callenfels in 1933 accompanied by H. D. Noone and A. A. Cense. In November-December of that year they performed successful excavations in the Leang Tomatua Katjitjang (Cave of the Lonesome Old Man). This cave was situated north of Tjani. Apart from flakes, blades and barbed arrow-heads, he found two bone points with serrated edges, a stone bark-beater, a bone spatula of the Sampung type, a few bone spear-heads of Muduk type 106 and two fragments of green glass bracelets, triangular in cross-section. One of these was found at a considerable depth, a fact which made van Stein Callenfels decide to fix the absolute age of the Toalean at 300-100 B.C. No report was published on this excavation or on that of the Sebang Cave in the same area.107

In 1933 Cense on one of his official tours discovered a new Toalean site at Ara; the site is situated on the most southern point of SouthWest Celebes opposite Salayar Island. Its geological formation consists

105 Sarasin; '08.

106 MacCarthy; '40b, 313-19. A Muduk point is a double-pointed piece of bone, oval or flattened-oval in section, usually flat on the inner side, convex on the outer side, and shaped (usually on both sides) by grinding so as to produce a fusiform shape. The grinding often extends all around both ends contiguous to the points. They are bone barbs mounted in wooden spears, mostly used for spearing fish.

107 Van Stein Callenfels; '38b, 138-44. 
of recent coral reefs which have been uplifted in the Quarternary and partly cover the effusa of the Lompobatang near Kadjang. Several ancient beaches can be pointed out here; some geologists think that there are seven of these, beach III lies $30 \mathrm{~m}$., beach IV $50 \mathrm{~m}$. and beach V $100 \mathrm{~m}$. above sea-level. The prehistoric Ara site is situated on beach III. In July 1936, Cense invited me to visit Ara; we were accompanied by the septuagenarian Mr. Nurudin Magassing who had, as early as 1902, escorted the Sarasins to Lamontjong. During my visit it appeared that a district-officer had already made investigations so there was not much left for a closer examination. What had been left was excavated then and yielded the following objects: 29 micro stone arrow-heads and other small implements with serrated edges, among which was a single arrowhead with a concave, winged butt-end, two scrapers, a large triangular stone-point, a peculiar spatula-shaped bone object, seven bone points of the Muduk type and a fragment of a sting-ray. The only ornament was a light blue glass spiral. The deposit was only $40 \mathrm{~cm}$. thick. The barbed objects were dominant in contrast with similar finds in other Toalean caves. The implements are small-sized, even for the Toalean. The teeth of the serrated tools are rather strongly developed in some cases, relatively blunt and cut perpendicular to the axis of the object instead of backwards. In my opinion, such tools can only have been used for the spearing of fish. The bone spatula was made of an ulna which had not been split and only worked at the distal end. Potsherds occurred mostly near the surface. There were no human remains except for a small but strongly-built mandible with the small teeth in situ. This mandible probably was worn as a memento. I suppose that the Ara site may be considered as one of the latest Toalean sites, dating well up into historical times. 108

Next followed the excavation of the Leang Karassa' (Ghost Cave) on the Chamba Road in the limestone mountains east of Maros, near the village of Patanuang AsuE. More Toalean sites were afterwards discovered in the same hills and the last investigations in 1950 led to the discovery of cave-paintings and negative hand-stencils in these regions.

The Karassa' Cave is a spacious rock-shelter which partly inclines over the road; 109 its deposit consisted mainly of sand, fresh-water molluscs and ashes. The shells themselves formed a real kitchenmidden one metre thick, cemented only directly against the rock wall. It yielded

108 Van Heekeren; '37a, 30-33.

109 Van Heekeren; '37-38, 263-67, 281-85. 
quite a number of prehistoric artifacts, made of andesite, chalcedony and bone. Chalcedony was found cemented as lumps in the limestone riverbed at some metres distance from the cave. The shellbank which contained the artifacts was not stratified. Numerous blade-tools, scrapers, points and bladelets as well as 23 stone implements with serrated edges were found. There were some remarkable bone points as well, and a number of stone tools which differed from the Toalean proper by their patina and archaic forms. There were tools of a more or less Mousterianlike type and notched artifacts. Winged arrow-heads were not found, and potsherds occurred only in the uppermost layers. Although the Karassa' Cave should be considered as one of the oldest Toalean sites, the accompanying fauna did not appear to comprise fossil animal remains which means that this site is also of Post-Glacial age. 110

This cave also yielded a small, but strongly-built human mandible; the teeth were missing.

In 1937 I continued the investigations in South Celebes, the main purpose being to gain more data concerning the structure of the Toalean complex and to increase our knowledge of its geographical dispersal. This time I examined the Panameanreanga Cave in the Matampa Mountains near Pankadjene, which is a continuation of the Maros limestone mountain-range. In this cave, the Toalean did not show up until $1.05 \mathrm{~m}$. below ground-level, under a bank of marine shells. This trial excavation was followed immediately by one of the Saripa Cave near the Chamba Road near km. 46 on the right bank of a small river which cuts through the limestone. On the opposite bank, a few kilometres further, lies the before-mentioned Karassa' Cave. The Saripa Cave proved to be a rich Toalean site, and yielded thousands of primary flakes and blades which were found throughout the whole stratum which started immediately below the ground-level and reached only as deep as 40 to $50 \mathrm{~cm}$. Beneath this stratum was a sandy layer containing shells and a few stone implements. At a depth of $1.10 \mathrm{~m}$. the rock-bottom was struck. The implements are conspicious by their fine workmanship and abundance in types. They were mostly made of chalcedony and a similar hard and brittle stone. There were a large number of arrow-heads, about $80 \%$ of which possess a concave butt-end and show a Neolithic habitus. 111 Nearly half of these were neatly serrated along the edges. Perfectly symmetric pieces were rare. In some instances the points of the arrow-

110 Van Heekeren; '41, 229-37.

111 Van Heekeren; '39b, 112-18. 
heads had been made with painstaking care and had been skillfully retouched all over, other pieces had been provided with the sharpest of points. There were two small stone saws and two peculiar borers of the 'perçoir sur lame' type which, if found in Europe, might well be taken for Aurignacian-Solutrean implements. Other types encountered were: blades, double-sided knives, borers, awls, tanged points, gravers, corescrapers, some true microliths and a few crude stone flake-tools. Some bone points had been hardened by fire and entirely polished afterwards. Finally, there was a number of small and round, dark-brown pellets or marble-like stones with a smooth and shining surface. It is not clear what they are. Human skeletal remains were completely absent.

In the same year van Stein Callenfels resumed his investigations into the Toalean Culture in South Celebes. He was assisted by W. J. A. Willems and F. D. MacCarthy. ${ }^{112}$ It appears that four caves or rockshelters were examined. The activities started with the excavation of a rock-shelter known as the Panisi Ta'buttu, situated at the Salo Parusi about $11 \mathrm{~km}$. southwest of Palakka in Bone. Here, too, as was the case with most caves in south Celebes, the deposit proved to be too shallow to be stratified. Mention was made for the first time of the presence of tanged tools; the cave also produced 16 serrated artifacts, a number of stone and bone points, some of which of the Muduk type, blades, knives, shell scrapers and a few bone spatulas.

Next followed the excavation of the Tjadang Cave near Tjita on the Wallanae River in the Soppeng district by Willems and MacCarthy. This steep-sloping cave produced potsherds, a few metal objects, scrapers made of shell and twelve barbed stone artifacts. In addition, three fragments of human mandibles, one with two, the other with three molars, and a great number of isolated teeth and some human bones were found.

Resident ter Laag had drawn attention to two caves on the south coast in the vicinity of Bonthain. Both caves were examined by van Stein Callenfels. One of these caves presented a stratum as thick as $3 \mathrm{~m}$. No report has been published.113 The first cave, Batu Edjaya (Red Stone Cave), still receives worship from the population in the form of rites which include the setting free of a chicken. The upper layer contained objects of a comparatively recent date, e.g. 1-cent pieces and old Dutch coins. Next followed a compact layer of potsherds between 18 and 40 $\mathrm{cm}$. below the ground-level; the sherds were decorated with comb-like

112 Van Stein Callenfels; '38b, 138-44.

118 Van Stein Callenfels; '38a, 579-84. 
patterns, scrolls, spirals, leaves and rosettes. Among the potsherds were small stone implements, a few polished stone adzes and fragments of bronze bracelets. Van Stein Callenfels dates this layer 300 B.C. He found that bone points of the Muduk type were abundant in this layer. The excavation of the second cave, Panganreang Tudea, produced not only the typical Toalean with its barbed stone tools, but also an older layer, clearly distinguished stratigraphically, containing implements resembling those which were discovered by Bühler in Timor and Roti 114 and by the present author in Besuki, Java, and by Willems in the Tuban Caves. Characteristic in this lower, older layer are tanged implements and scrapers of a characteristic shape. Apparently we are dealing with an industry which represents the forerunner of the Toalean proper and which van Stein Callenfels therefore named the Proto-Toalean. It so appeared that the Toalean is a mixed culture displaying two elements: a. The Proto-Toalean with the tanged elements and $b$. the northern element with barbed stone implements (well-known in Japan, Korea and the Philippines, but not in Java or in Sumatra. (Pl. 28, 29).

Lately the present writer had the opportunity to re-examine the finds of this cave and to study the cultural stratigraphy as well, with the assistance of van Stein Callenfels' field record book. The most important feature was the great abundance of true microliths, such as batteredback points, trapezes, crescents and triangular bladelets. My preliminary drawing of a stratigraphic scheme resulted in the recognition of three different cultural layers (Fig. 17):

Toalean I or Upper Toalean, with serrated arrow-heads, bone Muduk points, scrapers made of shell, and potsherds;

Toalean II or Middle Toalean, comprising beautifully struck blades and warped blade-points, arrow-heads with rounded butt-ends and numerous true microliths;

Toalean III or Lower Toalean, containing larger and crudely chipped flakes, some plain blades, flake-tools with notches and pedunculated blade-implements. The latter have been found in the upper level of the third layer only.

In May 1939, Willems excavated some caves in the neighbourhood of Makale and made some preliminary excavations along the Mandar Gulf without results.

114 Van Heekeren; '49, 89-108. 


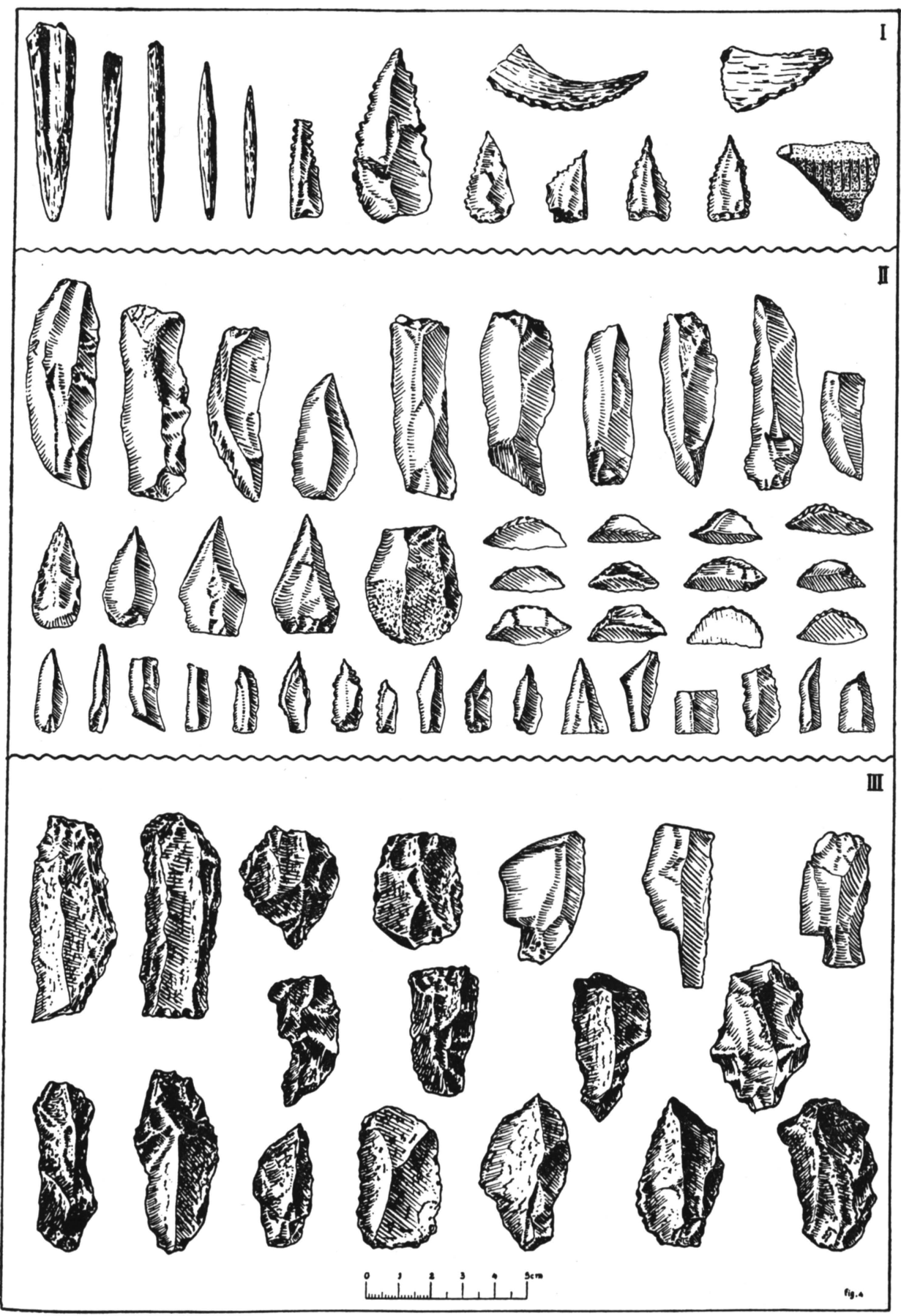

Fig. 17. Panganreang Tudea Cave, Sth. Celebes.

I. Upper Toalean; II. Middle Toalean; III. Lower Toalean. 
From March 11 till July 8, 1947, I undertook a systematic excavation of the Bola Batu Cave (Stone House Cave), a cave in the upper part of a dome-shaped limestone hill, about $191 \mathrm{~m}$. above sea-level, near the village of Badjo in the Barebo district of the State of Bone and about $20 \mathrm{~km}$. southwest of the capital Watampone. The cave is illuminated by some diffuse light penetrating through two entrances and a large hole in the ceiling. Apart from 240 stone implements which represent $73.6 \%$ of the total finds, 43 bone artifacts and 141 shell tools were found. Also a few slightly mineralized human calvarium fragments, a mandible with n:olars, some isolated teeth, the relics of killed game and numerous molluscs. No winged arrow-heads or other Neolithic relics have been found, except for a fragment of a round axe among the Toalean layers. In the upper layers a number of barbed stone arrow-heads were found and some tanged blade-tools in the lower layers. Among the blacie-tools were scalene triangles of a semi-microlithic character, Pirri-points, convex-based stone points and core-scrapers in the lower stratum of the excavation. Some glazed potsherds of Chinese origin were recovered at a rather great depth.

From February 17 till April 5 1950, I excavated the Leang PattaE (Cave of the paintings). It is situated $30 \mathrm{~m}$. above sea-level at the foot of the Maros Limestone Mountains, in the vicinity of LeangLeang in the Turikale district. About $100 \mathrm{~m}$. farther runs a small, apparently nameless river. The examination could not be finished due to the riots which broke out in South Celebes. Potsherds occurred only immediately below the ground-level, serrated and winged arrow-heads exclusively in the upper layers. Most artifacts were made of stone such as chalcedony and jasper. Blades of varying measurements were frequent; they varied from $25 \times 7$ to $66 \times 33 \mathrm{~mm}$. Many of these blades must have been hafted and used for several purposes. The stone implements are small but, with some exceptions, not entitled to the name 'microlith', the less so because real geometric forms are almost absent. Among the finds, however, occurred some very small points with careful retouching along one edge; they resemble similar points of the Eurafrican Capsian and the Bondi points of South Australia. The finds are as follows:

\section{Neolithic:}

16 winged and barbed stone arrow-heads, 5 barbed arrow-heads, 1 tanged, barbed arrow-head, 1 stone, bearing traces of sawing, 1 perforated stone, 3 potsherds. 


\section{Mesolithic:}

6 tanged points, 19 round-based points, 6 obliquely truncated points, 6 battered-back points and crescents, 5 gravers, a great number of blades, 12 cores, 14 shell points, and 1 polished bone point.

In studying these data it has to be emphasized that only sector I has been completely excavated, while of the sectors II and III only the upper layers had been removed when the work had to be interrupted. The data just given can therefore not give a correct ratio of the younger and older elements. In addition to thousands of Brotia and Thiara shells, there were also remains of killed game. Traces of hearths and charcoal were found in several places at different levels. All layers yielded red Haematite. In this cave, for the first time, rock-paintings were discovered.115

From the previous pages it is clearly to be seen that the so-called Toalean has been found in 19 different caves. It appeared that the people who introduced this culture lived mainly on edible fresh-water molluscs as well as from hunting small and big game, fishing, and gathering edible wild plants. Several caves in the Maros Limestone Mountains possess a bank of cemented molluscs against the rock wall, and more than one of these contains calcined vertebrates and artifacts. These banks lie from one to three metres above the level of the cave's deposit. We found this phenomenon in the Karassa', Saripa and PattaE Caves, but it was most distinctly developed in the Burung Cave. (Fig. 18).

During our excavation of the PattaE Cave, Mrs. Dr C. H. M. Palm discovered on February 26th 1950 a number of negative hand-stencils on a red background in the innermost part of the cave. On the ceiling about two metres above the floor-level were 7 hand-stencils standing out against a red background; against one of the hands was a small crescentshaped figure. There was another figure with five strokes, probably representing another hand. It appeared that the left hand had been spread against the ceiling, the space between the fingers and the surrounding area had then been splashed or spat at with a red pigment or paint, a procedure showing that the stencils had been made one hand after another as splashes from one hand could be traced on another. The red mineral has peeled off in several places and has caused the loss of many details. With one exception, all stencils are of left hands. The hands in this cave are slender with well-shaped fingers, and of

115 Van Heekeren; '52, 22-35. '55, 34-37. 
normal size. Next day, I myself discovered in the same portion of the cave but in a niche, a fine contourdrawing of a leaping boar in red brown striped line technique (Pl.31). On its back and neck are a series of five or six tufts of hair. Its head shows two horns giving the impression of tusks, but they are drawn behind instead of before the eyes and are bent the concave side forwards, not backwards. It is probable, therefore, that the supposed horns are really two bristles. The clumsy body and the thin legs are reminiscent of Babyrousa, but this animal has practically no hair or mane. The cardiac region displays an object that can be taken for a spear-head, a sympathetic magical sign, aiding the hunter in hitting the animal in its most vulnerable spot.

On March 5th we discovered a distinct hand-stencil on the ceiling of a practically inaccessible niche cut in a steep rock wall of the Burung Cave (a few kilometres east of the PattaE Gave), about $8 \mathrm{~m}$. above the ground-level. In examining the niche we found traces of two other hand-stencils; all three stencils are negatives and made against a red background. One of them was that of a right hand (P1. 32). In the same rock wall is a high tunnel which after a few metres curves to the right and debouches into the open air. On the ceiling near the entrance we discovered traces of several hand-stencils, but the red paint appeared in such a state of weathering and was so blistered, that the stencils were hardly recognizable; their number and details could not be established. Near the exit of the tunnel were two hand-stencils; one is made on the ceiling and is the negative print of a right hand, the other on the sidewall and badly preserved.

C. J. H. Franssen had found a number of hand-stencils in a cave complex which we have named the Leang DjariE (Cave of the fingers). The site consists of a complex of tunnels, halls and fissures. Just inside the entrance we noticed on the ceiling of a small niche two groups of respectively seven and five hand-stencils on a red background. Though they could easily be discerned, many of their details have vanished owing to the weathered condition of the pigment. Deeper in the cave on a spot where the entrance narrows, are four negative hand-stencils; one of these had four, another only three fingers, while a third displayed fingers tapering in the same way as one of the stencils in the PattaE Cave. At a higher level of the rock wall is another small cave which can only be reached by means of a ladder. Though its ceiling is covered with a greenish film of moisture, two groups of respectively four and five stencils could be distinguished. From the second group the thumbs are all absent. Finally, we found in a fissure four hand-stencils which were 
in a bad condition as a result of the weathered red ochre. The handstencils in this cave complex amount to twenty-nine.116

Many caves contained human skeletal remains, but no complete skeleton or skull has ever been found in the true Toalean deposits; the remains found in the caves were parts of the skull, some of which had been perforated artificially, mandibles, isolated teeth, fragments of the extremities being scarce. Therefore, the Toaleans buried their dead outside the caves or practised tree-burial. The bones were gathered in course of time and distributed among the deceased' relatives who adorned themselves with them and wore them as mementoes. It reminds one of the burial rites of the Andaman Negritos, the Melanesians and some Australian tribes. The Kurnai of Southeastern Australia for instance make it their habit to wear the lower jaws on their breast. According to A. R. Brown 117 the Negritos of the Andamans dig up the bones or take down the bones of the deceased and the skulls and jaw-bones are worn round the neck either in front or behind. The other bones are also preserved, but not treasured like the skull and lower jaw; they are often mislaid. These Negritos did not generally use stone tools, but employed arched scrapers of shell like the ones found in numerous caves in Java, Southern Celebes and Flores. Their only stone tools were quartz chips for hair-cutting, tattooing and sacrification. These sharp flakes were used only once and then thrown away on rubbish-dumps.

The skeletal remains in the Toale caves indicate peoples with a small stature and small teeth. Those of the Bola Batu Cave have been minutely examined by Dr D. A. Hooijer;118 there were skull fragments, a lower jaw and isolated teeth from four different individuals. The human skeletal fragments of the Lampoa Cave 119 were also examined. Hooijer has published the following results:

1. The skulls show no characters that are typically Veddah-like; the frontal bone is larger than the average in Buginese and Macassars, and the mandible is high in relation to its width, falling above the Veddah range in this respect.

2. The permanent teeth in situ are small compared with those of Buginese and Macassars, but this is most probably due to the sub-fossil teeth having belonged to a female, and the recent Celebean skulls

116 Van Heekeren; '52, 22-35. Heyning; '50, 21-30.

117 Brown; '33.

118 Hooijer; '50a, 7-160. '55, 153-63.

110 Franssen; '49, 331-39. 


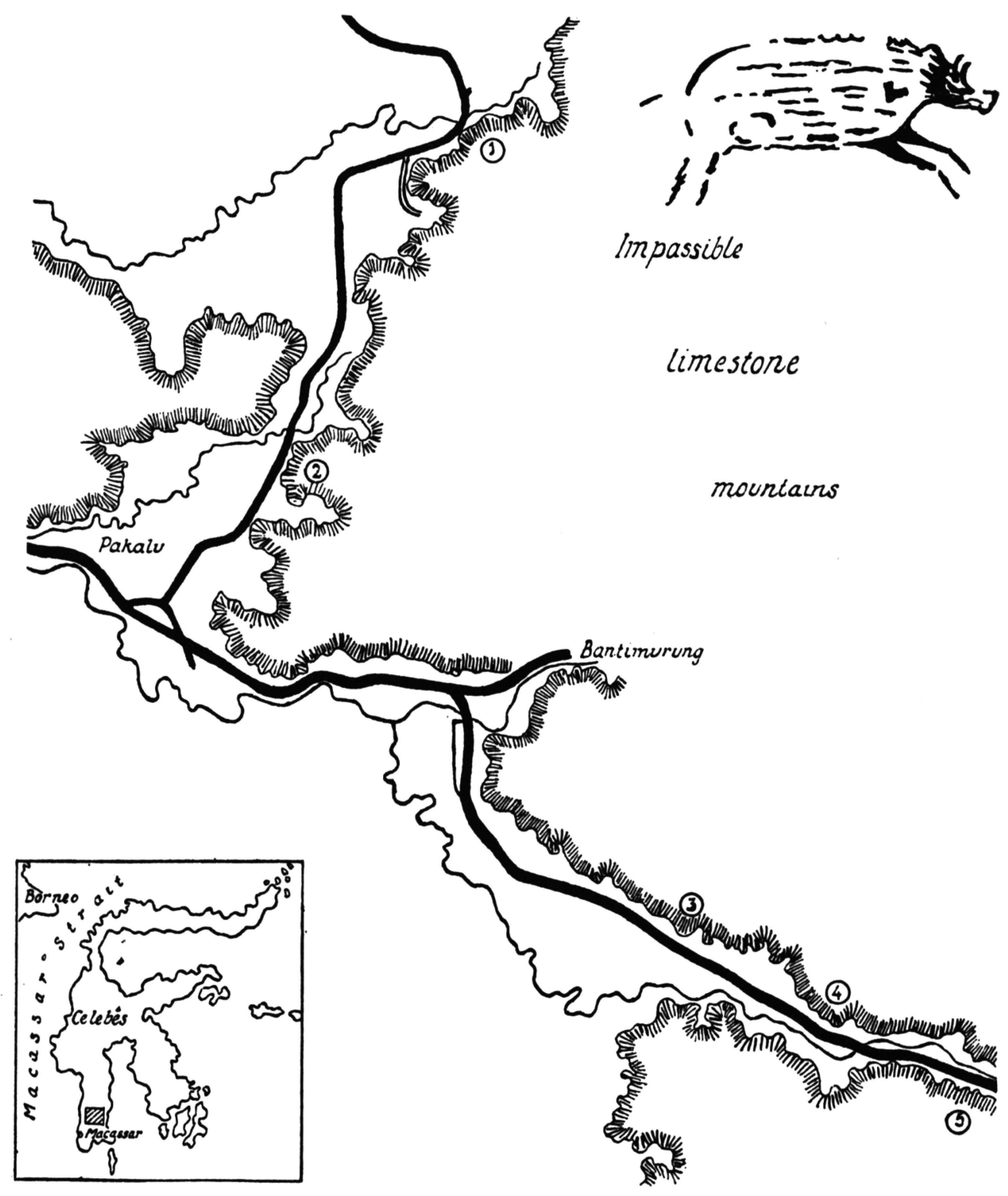

Fig. 18. Toalean sites East of Maros, Sth. Celebes.

1. PattaE Rock-shelter; 2. Burung Cave; 3. DjariE Cave; 4. Saripa Cave;

5. Karassa' Cave. 
used for comparison to male individuals. Some of the isolated teeth are not particularly small, however.

3. The milk dentition is large, some elements are at, or even over, the maximum size recorded for all living races of Man.

4. In the post-cranial skeleton, though primitive, no special Veddah characteristics are apparent either, and the structure of its ulna points to the sub-fossil Toalean Cave Man as a form more advanced than the living Veddah. The robusticity of the humerus is very low. The tibia is not shown to be mesocnemic. The astragalus and the calcaneum exhibit primitive characters, judged by European standards, and conform well with the corresponding Veddah bones.

5. The remains in the Bola Batu Cave point to four to seven individuals; those of the Lampoa rock-shelter partly belonged to an individual, the stature of which was probably only $142 \mathrm{~cm}$., but one larger individual, at least, was present too.

The anthropometric studies of Mijsberg 120 on the living Toale, and of Hooijer on sub-fossil skeletal fragments, suggest that the Toale and their ancestors do not differ significantly. The Sarasin's view that they represent impure Veddah relics is untenable.

The associated fauna of the Toale Industry is, geologically speaking not very old since all species belong to a recent fauna. This has recently become known by Hooijer's outstanding monograph.121 Even a mineralized lower jaw in the cemented bank of the Burung Cave is that of Sus celebensis. Hooijer describes the fauna which has been excavated from the Bola Batu, Tomatua Katjitjang, Sebang, Panisi Ta'buttu, Panganreang Tudea and Batu Edjaya Caves and indicates its distribution over the Toalean sites.

\section{MARSUPIALIA:}

Phalanger ursinus Temminck. Rare; represented only by some mandibles and teeth. In some caves larger than the present day species.

Phalanger celebensis Gray. Found in various caves.

Phalanger celebensis callenfelsi. A large new form, discovered in the basal layer of the Panganreang Tudea Cave.

120 Mijsberg; '41, 1279-1309.

121 Hooijer; '50a, 7-160. 
Phalanger ursinus Temminck Phalanger celebensis Gray Suncus murinus L.

Macaca maura Geoffr. et F. Cuv. Homo sapiens $L$.

Lenomys meyeri Jentink Rattus dominator Thomas Rattus cf. xanthurus Gray Rattus cf. rattus L.

Rattus cf. coelestis Thomas Macrogalidia musschenbroekii Schlegel Sus celebensis Müller et Schlegel Babyrousa babyrussa $L$. Anoa quarlesi Ouwens Anoa depressicornis Smith

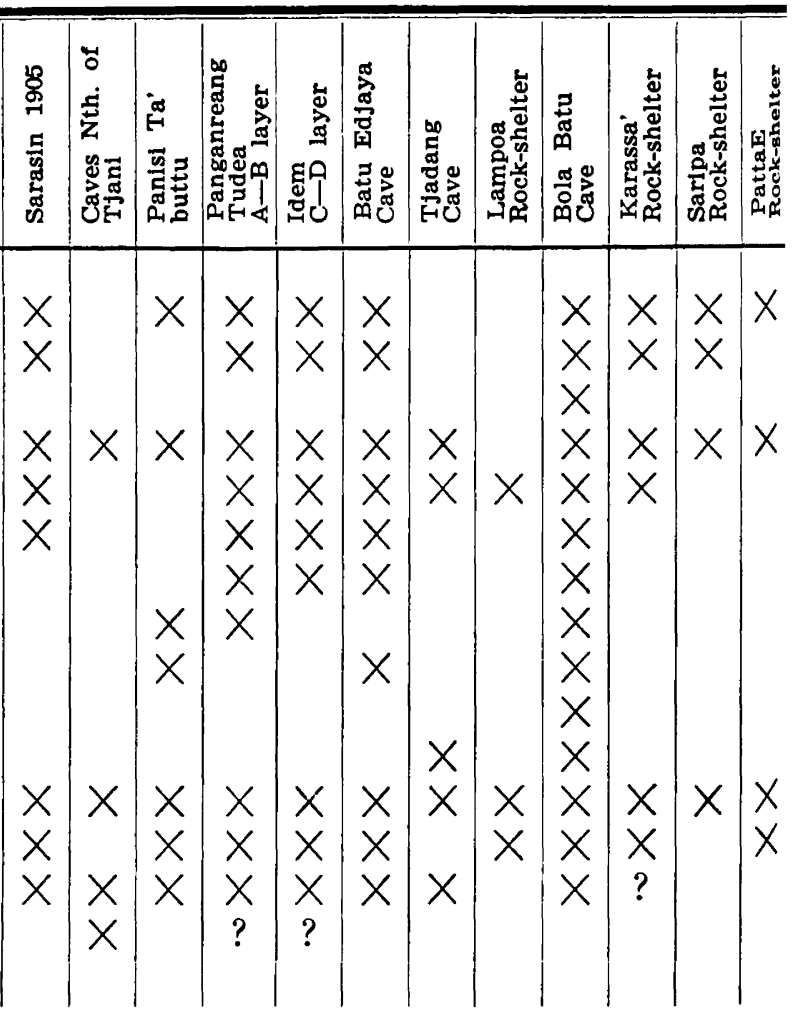

\section{INSECTIVORA:}

Suncus murinus L. Only a calvarium, excavated from the Bola Batu Cave.

\section{PRIMATES:}

Homo sapiens $\mathrm{L}$. Skull fragments and mandibles in various caves. Macaca maura Geoffr. et F. Cuv. of frequent occurrence in several caves.

Macaca maura majuscula. A large new subspecies from the Bola Batu Cave.

\section{RODENTIA:}

Lenomys meyeri Jentink.

Rattus dominator Thomas. 
Rattus sp. cf. xanthurus group.

Rattus sp. cf. rattus group.

Rattus sp. cf. coelestis group.

\section{CARNIVORA:}

Macrogalidia musschenbroekii meridionalis. For the first time discovered in this area; still existing in the Minahassa.

\section{ARTIODACTYLA:}

Sus celebensis Müller et Schlegel. Oldest remains in caves belong to a species smaller than the present-day Celebes wild pig; the increase in size was gradual.

Sus celebensis sarasinorium. Found in the Bola Batu Cave.

Babyrousa babyrussa $\mathrm{L}$. Now vanished from the southwestern part of Celebes. Oldest examples in caves larger than the Babyrousa still living in Central Celebes.

Babyrousa babyrussa bolabatuensis. A new subspecies from the Bola Batu Cave.

Anoa quarlesi Ouwens. Oldest remains in caves are slightly larger than the present-day species.

Anow depressicornis Smith, rare in the Toalean caves.

During his examination Hooijer noticed that the present fauna possesses reduced measurements in comparison with the remains from the caves. Only Sus celebensis makes a notable exception. This pig which still exists in Celebes is larger than its prehistoric ancestor.

In 1948 Franssen performed a small excavation in the Lampoa Cave, situated on the Chamba road, East of Maros. ${ }^{122} \mathrm{He}$ exposed a culture related to the Toalean Industry in which barbed or winged stone arrowheads were not present; Hooijer stated that the mammalian remains from this cave belong exclusively to Babyrousa. A human skull which was put together inexpertly by the finder is now at Surabaja. There were numerous molluscs which have been examined by Mrs. W. S. S. van der Feen Jutting at Amsterdam. The most frequent were Brotia perfecta Mousson, Neritina pulligera and Neritina iris Mousson. Next Thiara crenulata Deshayes. These species had formerly all together been called Melania. Oysterlike molluscs are Batissa violacea Lamarck and Polymesoda suborbicularis. The latter had formerly

Franssen; '49, 331-39. 
been named Cyraena. The shells of these molluscs in particular have been used by the cave-dwellers for the manufacture of shell scrapers. All above-mentioned species are fresh-water molluscs. Finally there were a few examples of two kinds of land-snails: Hemiplecta rugata Martens and Cyclotus fasciatus Martens.

\section{B. J a va.}

Flake and blade industries allied to those of South Celebes have been found on Java, Sumatra, Flores, Timor, Roti and Borneo. A. C. de Jong and G. H. R. von Koenigswald in 1930 made a great number of surface-finds of obsidian flakes and blades. The artifacts from the Bandung Plateau came from twenty-three different places, most of which are situated about $723 \mathrm{~m}$. above the sea-level, and mainly centre around a lake which has now entirely vanished (Fig. 21). East of Dago in particular are four rich sites which together yielded 10.000 primary and chipped obsidian flakes. They were all collected from the surface, on tops of hills and in some instances from road cuttings, where they have mainly been found in the upper level. The raw material must have been supplied from the neighbourhood of Nagreg, a small village where numerous obsidian bombs lie on the surface. Von Koenigswald 123 also mentioned the presence of neolithic adzes and large quantities of Haematite. The implements are small-sized, but nevertheless I hesitate to qualify the entire industry as microlithic as has been done by some who studied the material. The percentage of true microliths which are not only small in size, but also geometrically shaped, is proportionally small. And, in my opinion, this industry is not Neolithic either. $95 \%$ of the Bandung flakes are made of obsidian, the remaining percentage of chert and andesite. It is not known where the extensive collection of von Koenigswald is now; a very small part of it has been deposited in the Djakarta Museum. From a very recent publication by Georg Bandi,124 it appears that $\mathrm{J}$. Krebs also started a collection principally in Dago in the years 1932 and 1933. He donated this collection to the Basel Museum in 1936. The same museum received collections of similar obsidian flakes from W. Mohler and W. Rothpletz, both of whom founded their collection during the Japanese occupation in the years 1943-45.

123 Von Koenigswald; '35, 394-417.

124 Bandi; '51, 127-61. The theory that the sites are strictly limited to places round the ancient Bandung lake is, however, not tenable. This was proven by recent explorations by Mr. Rothpletz; findspots with obsidian implements were found as far as over $1300 \mathrm{~m}$. above the sea-level. 


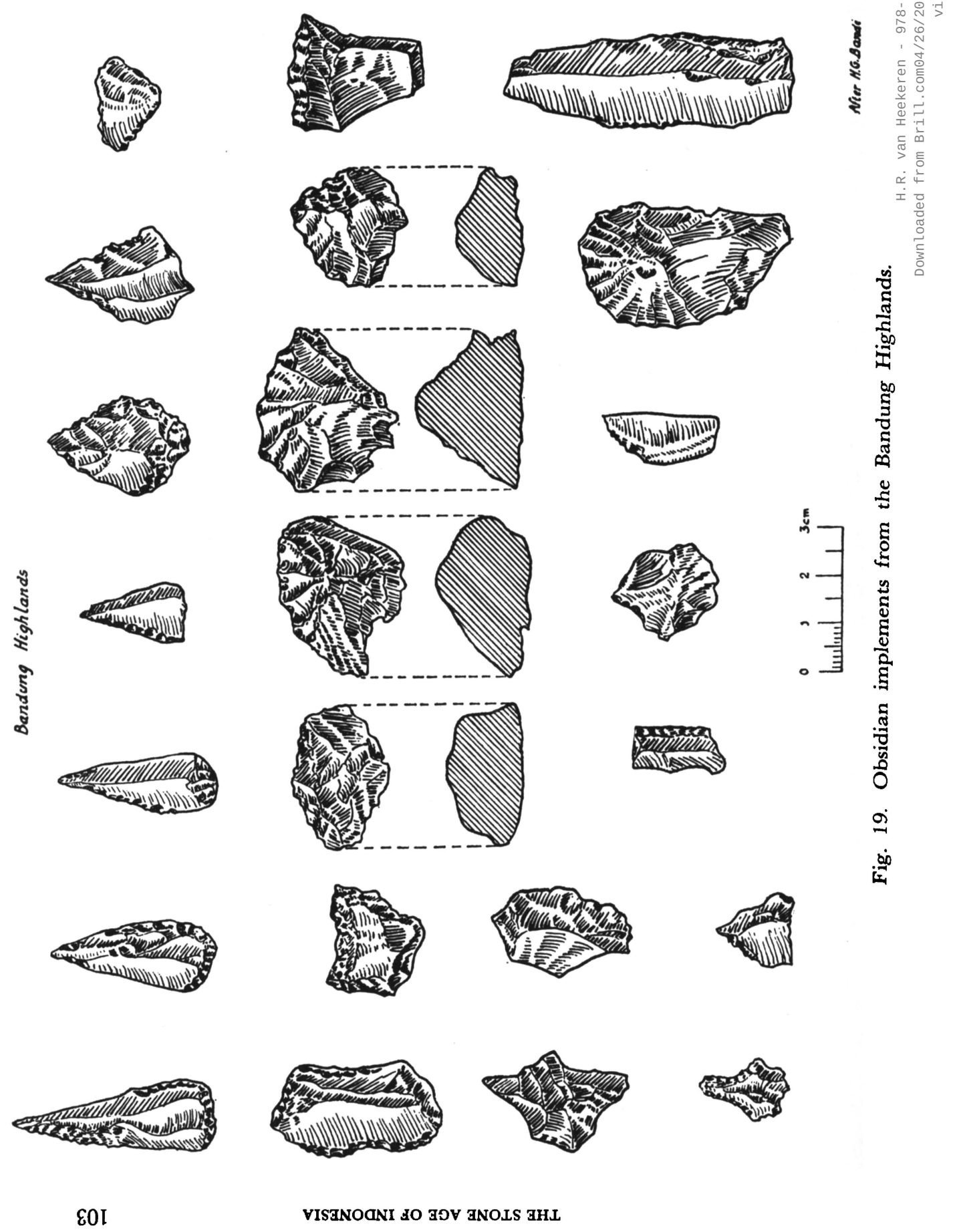


Bandi states that the material shows a lack of uniformity; the majority of the objects consists of primary obsidian flakes and waste products. True blades are scarce. Among the well-worked and minutely retouched flakes are 291 flakes with edge chipping as a result of use, 159 flakes with marginal retouches; moreover, there are 238 typical implements such as arrow-heads with obliquely truncated edges, side- and core-scrapers, gravers and knives (Fig. 19). Marginal retouches are nearly always on the upper surface of the object, whereas alternate retouching is rare. The arrow-heads which mostly possess a chipped butt-end and point are retouched along the long margin; the butt-end is often convex and seldom straight. There are also irregular-shaped trapezes. The Bandung collection comprises 889 flakes which have been divided as follows: 49 arrow-heads, 46 shouldered scrapers and end-scrapers, 9 shouldered core-scrapers, 25 core-scrapers, 62 side-scrapers and end-scrapers, 21 gravers, 11 borers, 5 knives and 10 special forms. Furthermore 159 flakes with retouches, 291 flakes with retouches as a result of use and 201 flakes without retouches.

In two caves in Besuki, East Java, the present writer found a related stone industry, but associated with the Sampung Bone Culture. The caves in question are the Betpuruh Cave near Pradjekan (examined in 1933) and the Sodong Cave near Puger on the Southcoast (examined in 1931-35). In the first rock-shelter, the Bone Culture was predominant, the flakes and blades of secondary importance. 125 But the Sodong rockshelter yielded better results. It is situated on the northern edge of the Watangan limestone massif. The rock-shelter is divided into two terraces, displaying a difference in level of two metres, and separated by a large stalagmite. In the first terrace was a deposit thick enough to be stratified. The upper layer yielded only potsherds, Chinese coins and a few bricks but no prehistoric objects. The next layer, at present 20 metres above sea-level, consisted of a marine deposit of shell and corals, but was barren of cultural objects. The third layer produced a Vertebrate Fauna including a large human molar; the bones showed traces of calcination. The fourth layer contained the prehistoric stone and bone culture; the implements comprised 6 bone spatulas, 12 bone points (including $\mathrm{Mu}-$ duk-types), 4 small Sumatraliths, points and scrapers of shell, 67 stone flakes and blades, including double-sided knives, gravers, points, scrapers and 8 Pirri-points. They were made of chalcedony, jasper, obsidian and andesite ( $\mathrm{Pl}$. 26b, 30). There were no potsherds. The fifth layer was

125 Van Heekeren; '35, 123-29. '36, 187-93. 
stone-hard and contained nothing of importance, but the sixth and lowest layer, three metres below the ground-level, produced a few slightly mineralized bones; the lower part of a tibia of a sub-fossil banteng and the lower part of a fore-limb of a prehistoric waterbuffalo.126 The stone artifacts are small-sized, but the number of true microliths is relatively small; there were many pieces of red Haematite. The upper terrace was a deposit only one metre thick. It yielded many arched scrapers of shell with marginal retouches and a mother-of-pearl amulet with three round holes in it, besides some isolated human teeth which were little worn and equaled the Sampung teeth in size. Right at the bottom of the lower terrace was the skeleton of an adult pygmy, its stature being estimated approximately at $142 \mathrm{~cm}$. Unfortunately the skull was missing with the exception of the right side of the lower jaw, in which the badly-worn teeth were remarkably small. The wisdom-tooth was present. The upper part of the body was on the back, the ribs and the remains of the spinal column between them, clearly visible. The lower extremities lie crossed over each other; the right upper and lower leg lie with their posterior surface flat on the ground. The left leg was found in a position showing that the knee projects a little laterally from the middle of the right upper leg. The right leg is also bent in the hip and more still in the knee. Above the cranial part of the right femur, part of the pelvis is to be seen. Right tibia and fibula lie parallel, the fibula slightly behind and cranially in regard of the tibia. Both are broken in several pieces. The left tibia and fibula lie not as fully parallel as the right ones. The condyles are slightly crossed, fibula on top, the cranial parts diverging about $6 \mathrm{~cm}$. Left femur, broken in five pieces, lies closer to the surface. (Pl. 27). The skeleton was lost due to the war before it was properly examined by an expert.

When classifying the material from the Tuban Caves which had been excavated by Willems in 1938, I found many flakes and blades which had been discovered in association with artifacts of shell, bone daggers, bone spatulas of the Sampung type, and also winged bifacial and monofacial arrow-heads; the Muduk bone point also occurs. But it is better to wait for a full description of the material before going further into the matter.

Finally Franssen collected a series of waste products and implements of obsidian, jasper and silicified limestone in the eroded valleys of a 
reddish brown lateric soil on the edge of a young volcano-mantle of the Salak Mountain at Leuwiliang, Bogor, in 1939.127

C. Su ma t r a.

In 1913 August Tobler from Switzerland did an exploratory excavation in the Ulu Tjangko Cave in Djambi, up-stream between the Maringin and Batang Tabir Rivers. The cave is situated in the limestone mountain which in some places is intersected by volcanic intrusions. In addition to 12 cores, the finds comprised 3 arrow-heads, 4 core-scrapers, 13 scrapers, 6 gravers, 2 borers, 14 retouched flakes, 123 flakes with edge chippings as a result of use and 118 flakes with marginal retouches. All implements were of obsidian and show remarkable likeness to the obsidian items of the Bandung Plateau. The very few human skeletal remains from this cave are cranial fragments, small-sized teeth, a fragment of the lower jaw with chin eminence, fragments of humerus, tibia and femur, perhaps showing a human race of small stature. The fossa olecrani of the humerus was perforated. Sarasin thought that they were the remains of short Veddoid ancestors of the Kubus who lived in the mountains. The finds are now in the Ethnological Museum in Basel, Switzerland.

Some years later, J. Zwierzycki 128 dug up a similar industry in a cave near Ngalan in the same area during the Palaeobotanic Djambi Expedition. The artifacts were made of obsidian and other stone. These finds are kept in the Geological Museum at Bandung.

In July 1939 Van der Hoop collected obsidian artifacts of the same type in the Danau Gadang Estate near Lake Kerinchi, Eastcoast of Sumatra. The lake's level lies 783 metres above the sea-level. Although Van der Hoop himself remarks: "The large size of many of these microliths is remarkable. Geometric forms as presented by the Tardenoisean were not found", 129 he maintains the terms 'microliths'. Reports on the presence of similar stone cultures from the other Indonesian islands are scanty.

D. B or neo.

Borneo, so difficult to travel, has attracted only a few explorers. But A. H. Everett discovered as early as $1878-79$, what is probably a Mesolithic Flake Industry in caves in Serawak. The implements were made of quartz. I. H. N. Evans found numerous flakes of quartz and chert on the mountain ridge in the Tempassuk region.130

\footnotetext{
127 Franssen; ' 41, 531-45.

128 Zwierzycki; '26, 63-67.

129 Van der Hoop; '40, 200-4.

130 Evans; '38, 141—46.
} 
E. The Lesser Sunda Islands.

Little is known from these islands. A. Bühler carried out excavations in seven places on Roti Island and scored success in two of them. Roti is a small island southwest of Timor, mainly consisting of raised limestone reefs. Caves are rare here. But in Western Roti, in Déngka, is an area with caves one of which, the Lua Neoal, yielded flints at a depth from $20 \mathrm{~cm}$. to one metre below the ground-level. They have to be classed among the flake industries and show secondary chipping on the upper surface. The implements are rather primitive, but among them are a few good knives and points of yellow jasper and borers of redbrown and yellow jasper and a $11 \mathrm{~cm}$. long and $6 \mathrm{~cm}$. broad scraper. Vertebrates do not occur, but there were many shells of molluscs and a small tanged scraper of tortoise-shell.131

The artifacts excavated by Bühler and later by Willems in caves in Timor can probably only partly be classed among the flake industries. According to Sarasin mainly we are concerned here with an Early Neolithic culture which has developed from the Toalean. Fine tanged knives and blade-points, strangulated blades and small hand-axes constitute remarkable elements in these caves. ${ }^{132}$ There were also many potsherds.

Lately, Dr Th. Verhoeven discovered a primitive flake and blade industry in numerous caves and rock-shelters in West Flores. ${ }^{133}$. My own explorations in the same area (March-May 1952) were concerned with the excavation of two small rock-shelters. The first and most important one was called the Rundung Cave, situated near Wangka, Riung district. A great number of flakes and some blades of a semi-microlithic character, with a minimum amount of dressing, made from chert and obsidian, were collected. Many of them showed a distinct bulb of percussion; they have probably been used to cut and sharpen arrows, to bleed, scarify and incise in the way still practised in Melanesia and on the Andaman islands; concave scrapers and notched blades were obviously used to sharpen roundshafted weapons; there were also pointed bladelets, the butts of which are worked on in such a way that they could be inserted in a split bamboo or stick, as arrow-heads. Micro points, made on bladelets, and other similar micro blades have no geometric form whatever. The cores are irregular and flaked in all directions. It is obvious,

131 Sarasin; '36, 1--59.

132 Willems in Oudheidkundig Verslag 1938.

133 Verhoeven; '52, 95-98.' '53, 597-612. 
therefore, that the flakes have been detached rather at random. Ornaments were represented by small pendants of shell, mother-of-pearl, quartzite and obsidian; we found among others a lozenge-shaped pendant of mother-of-pearl and another of shell in the shape of a fish.
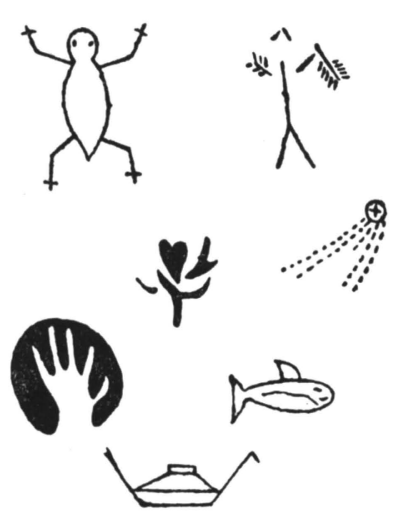
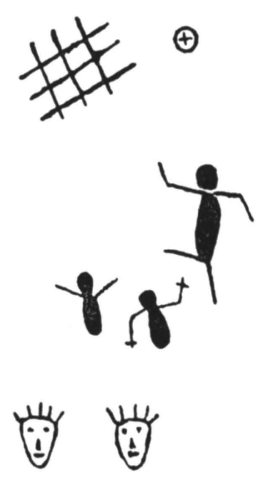

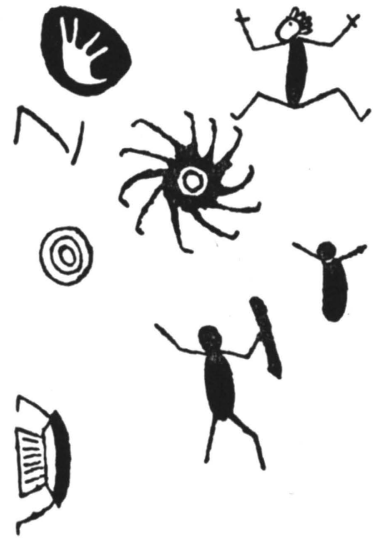

Fig. 20. Rock-paintings, Kei Islands.

A similar backward industry was found in the Soki Cave, half-way between Ruteng and Reo. The most surprising find was that of a microlith with battered-back of yellow-brown glass. It serves to prove that palaeolithic foodgatherers occupied this cave till very recent times.

On one of the Kei Islands hand-stencils occur next to pictures of masks, human figures with shields, fishes, boats and zoomorphic designs, done in the style with which we are already familiar from New Guinea and Australia (Fig. 20).

F. Ge ram.

On the coast of North Ceram near the village of Rumasokat on Seleman Bay, rock-paintings and series of hand-stencils have been discovered in five different places and on two levels; an older, badly weathered and reddish, and a younger, well preserved and white. Beside hand-stencils there were human figures with raised arms which would represent gods keeping watch over the fishes, and lizards and fish pictures. 134

All the above-mentioned flake and blade cultures may belong to one large culture group, which spread widely over the Indonesian Archipelago and finally reached the Australian Continent and Tasmania.

134 Röder; '38b, 19-28. 


\section{REFERENGES AND SELECTED BIBLIOGRAPHY.}

Bandi, H. G. 1951:

Bell, F. L. S. 1940:

Beyer, H. Otley 1947:

1948:

1951:

1952:

Brown, A. R R. 1933:

Carthy, F. D. Mc. 1940a:

1940b:

1948:

1949:

Colani, $\mathbf{M}$.

1927:

1929:

1930:

1932:
Die Obsidianindustrie der Umgebung von Bandung in West Java. Südsee-Studien, Mus. f. Völ. kerkunde, Basel, 127-61.

Rock-Paintings in New Guinea. Man, 60, 79.

Outline Review of Philippine Archaeology by islands and provinces. The Philippine Journ. of Science, 77, 205-373.

Philippine and East Asian Archaeology. Nat. research council of the Philippines. Manilla, 29, $1-130$.

A Tribute to Van Stein Callenfels. Journ. of East Asiatic Studies. Manilla, 1, 77-81.

Notes on the Archaeological work of $H$. R. van Heekeren in Celebes and elsewhere (19371950). Ibid, 3, 1-17.

The Andaman Islanders. Cambridge and New York.

A comparison of the Prehistory of Australia with that of Indo China, the Malay Peninsula and the Netherlands East Indies. Proc. 3rd Congress of Prehistorians of the Far East, 30-50. The one point, known as Muduk in Eastern Australia. Rec. of the South Austr. Mus., 20, 313-19.

The Lapstone Creek Excavation: Two culture Periods revealed in E.N.S. Wales. Ibid, 22, $1-34$.

The Prehistoric cultures of Australia. Austr.

Medic. Publ. Co Ltd., 19, 305-19.

L'Age de la pierre dans la Province de Hoabinh

(Tonkin). Mém. Serv. géol. Indo Chine, 14.

Hanoi.

Gravures primitives sur pierre et sur os.

BEFEO, 29, 273-87.

Recherches sur la Préhistoire Indo Chinois.

Ibid, 30, 299-422.

Le Protonéolithe. Praehistorica Asiae orientalis, 93-95. 
Collings, H. D.

1938a:

1938b:

Dammerman, K. W 1929:

1932:

1934:

1939:

Duckworth, W. L. H 1934:

Earl, G. W.

1860:

Es, L. J. C. van 1926:

1929:

Evans, I. H. N. 1938:

Franssen, C. J. H. 1941:

1949:

Friederici, G.

1913:

Fürer Haimendorf, C. v.

1936:

Heekeren, H. R. van 1935:

1936:
Notes on a recent paper: "The Melanesoid Civilizations of Eastern Asia." Bull. Raffles Museum, 1, 122-23.

An excavation at Bukit Chuping, Perlis. Ibid, 94-119.

On the zoography on Java. Treubia, $11,1-88$.

Donnée provisoire des Mammifères trouvés dans la grotte de Sampoung à Ponorogo. Hommage Prem. Congr. Préhist. Extr. Orient, Hanoi. $30-31$.

Voorhistorische menschen en dieren in Java. De Tropische Natuur, 23, 229-35.

On Prehistoric Mammals from South Celebes. Treubia, 17, 63-72.

Human remains from rock-shelters and caves in Perak and Perlis and from Selingsing. Journ. Mal. Branch RAS, 12, 149-67.

On the Shell-Mounds of Province Wellesley in the Malay Peninsula. Trans. Ethn. Soc. London, 2, 119-29.

Voorlopige mededeelingen over een nieuwe vindplaats van den praehistorischen mensch op Java. Hand. Vierde Ned. Ind. Natuurw. Congr., 468-74.

The prehistoric remains in Sampoeng Cave. Res. of Ponorogo, Java. Proc. of the Fourth Pac. Science Congr. Java, 3, 329-40.

'Melanesoid' Culture in Malaya. Bull. Raffles Museum, 1, 3, 141-46.

Praehistorische werktuigen uit de omgeving van Leuwiliang in de residentie Buitenzorg. TBG, $81,531-45$.

Bijdrage tot de kennis van het Toaliaan op Zuid Celebes. TBG, 83, 331-39.

Untersuchungen über eine Melanesische

Wanderstrasse. Wiss. Beiheft zum Deutschen

Kolonialblatte, 7.

Zur Urgeschichte Australiens. Anthropos, 31, $1-36$.

Prehistorisch grottenonderzoek in Besoeki, Java. A. De Goea Betpoeroeh nabij Pradjekan. Djawa, 15, 123-29.

Prehistorisch grottenonderzoek in Besoeki, Java. B. De Goea Sodong bij Poeger. Djawa, 16, 187-93. 
1937a:

1937b:

1937/1938:

1939a:

1939b:

1941:

1949:

1951:

1952:

1955:

Heine Geldern, $\mathbf{R}$. 1932:

1936:

1945:

Heyning, $\mathrm{N}$.

1950:

Hooijer, D. A.

1950a:

1950b:
Ara, een nieuwe prehistorische vindplaats in Zuid Celebes. TAG, 54, 30-33.

Ontdekking van het Hoabinhien op Java. De Goea Mardjan nabij Poeger. TBG, 77, 269-77. Aanteekeningen over een ingraving in de Liang Karassa nabij Maros. Tropisch Nederland, 10. 263-67, 281-85.

Over Praehistorie in het algemeen en die van Besoeki in het bijzonder. Djember.

De Liang Saripa, een neolithisch station nabij Maros. TBG, 79, 112-18.

Over Toala's en de Toalacultuur. (Zuid Celebes). Natuurw. Tijdschr. voor Ned. Indië, 101, 229-37.

Rapport over de ontgraving van de Bola Batoe nabij Badjo, Bone, Zuid Celebes. OV, 1941-'47, 89-108.

Korte Mededelingen: Het Hoabinhien in Zuid Borneo? TBG, 84, 4, 508-12.

Rock-Paintings and other Prehistoric discoveries near Maros (S. W. Celebes). Laporan Tahunan Dinas Purbakala 1950, 22-35.

Prehistoric Life in Indonesia. Djakarta.

Urheimat und früheste Wanderungen der

Austronesier. Anthropos, 27, 543-619.

Prehistoric research in Indonesia. Ann. Bibl.

Indian Arch., 9, 26-38.

Prehistoric Research in the Netherlands Indies.

Science and Scientists in the Nether. Indies.

New York, 129-67.

Prehistorische vindplaatsen bij Maros in Zuid Celebes. TAG, 68, 1, 21-30.

Man and other Mammals from Toalian sites in Sth. Western Celebes. Verh. Kon. Ned. Akad. van Wetensch., 66, 7-160.

Fossil Evidence of Australmelanesian Migration in Malaysia? Southwestern Journ. of Anthropology, 6, 416-22.

1955:

Gewervelde Dieren uit het Quartair van Celebes. Vakblad voor Biologen, 10, 153-63.

Hoop, A. N. J. Th. De Praehistorie. Gesch. van Nederl. Indië, 1, à Th. v. d.

1937:

1940:

1941:
Amsterdam.

A prehistoric site near the lake of Kerinchi, Sumatra. Proc. 3rd Congress of Prehistorians of the Far East, 200-4.

Catalogus der Prehistorische Verzameling. Bandoeng. 
Huxley, F. W. 1863:

Kleiweg de Zwaan, J. P.

1928:

1943:

Koenigswald, G. H. R. von 1935:

1952:

Krom, N. J.

1926:

Küpper, $\mathrm{H}$.

1930:

Lebzelter, V.

1935:

Mansuy, $\mathrm{H}$. et Colani, M. 1925:

Menghin, $\mathrm{O}$. 1928:

1933:

Mijsberg, W. 1932:

1937:

1940:

1941:

Müller, H. W. 1935:
Letter on the human remains found in shell mounds. Transact. of the Ethn. Soc. of London N.S., 11, 265-6.

Wat weten wij van de voorhistorische mensch in den Indischen Archipel en op het naburig Aziatisch continent? TAG, 45, 551-76.

De oudste mensheid van de Indische Archipel. Den Haag.

Das Neolithicum der Umgebung von Bandung. TBG, 75, 394-417.

Evidence of a Prehistoric Australmelanesoid Population in Malaya and Indonesia? Southwestern Journ. of Anthropology, 8, 92-96.

De Praehistorische Archaeologie van Java en Sumatra. Mensch en Maatschappij, 2, 378-79. Palaeolithische werktuigen uit Atjeh (Noord Sumatra). TAG, 47, 985-88.

Palaeolithische Funde aus Atjeh (Nord Sumatra). Arch. für Anthropologie, 23, 318-25.

Contribution à l'étude de la Préhistoire de L’Indochine. Mém. Serv. Géol. Indo Chine, $13,3$.

Zur Steinzeit Ostasiens., Festschr. P. W. Schmidt Wien 908-42.

Weltgeschichte der Steinzeit. Wien.

Recherches sur les restes humains trouvés dans les fouilles des abris sous roche de Goea Lawa à Sampoeng et des sites préhistoriques à Bodjonegoro (Java). Hommage Prem. Congr. Préhist. Extr. Orient, Hanoi, 39-54.

De bevolking van Ned. Indië anthropologisch en prehistorisch beschouwd. Natuurw. Tijdschrift voor Ned. Indië, 3.

On a neolithic Palae-Melanesian lower jaw found in a kitchenmidden at Guah Kepah, Prov. Wellesley, Str-Settlements. Proc. 3rd Congr. of Prehistorians of the Far East. Singapore, 100-18.

De anthropologische beteekenis van de Toala's in Zuid Celebes (op grond van metingen, verricht door wijlen Dr P. V. van Stein Callenfels). Geneesk. Tijdschr. Ned. Indië, 81, 12791309.

Die Kleinschädelformen Südostasiens. Zeitschr. f. Rassenkunde, 2. 
Mühlhofer, F. 1938:

Munsterberger, $\mathbf{W}$. 1940:

Naerssen, F. H. v. 1946:

Pei, W. C.

1935:

Rivet, P.

1932:

Röder, J.

1938a:

1938b:

1938c:

Sarasin, P. und F 1905a:

1905b:

1908:

Sarasin, F.

1933:

1935:

1936:

1938:

Sarasin, P.

1914:

Schürmann, H. M. E. Kjökkenmöddinger en palaeolithicum in Noord 1928:

1931:

Snell, C. A. R. D. 1948:

Steinwerkzeuge aus dem Muschelhugel von Bindjai-Tamiang in Nord-Sumatra. Wiener Prähist. Zeitsch., 25, 30-34.

Melanesische sporen in Noord Sumatra? Cult. Ind. 93.

De oudste cultuurstromen. In: Wat Indië ontving en schonk. Amsterdam, 7-55.

On a Mesolithic Industry of the caves of

Kwangsi. Bull. Geol. Soc. China, 14, 393-408.

Les Océaniens. Praehistorica Asiae orientalis, $35-46$.

Vorläufiger Bericht über einige praehistorische Arbeiten der Leo Frobenius Expedition, ausgesandt von Forschungsinstitut für Kulturmorphologie zu Frankfort-Main. Proc. 3rd Congr. of Prehistorians of the Far East. Singapore, 233-34.

Die Felsbilder im Fluszgebiet des Tola (Süd West Ceram). Paideuma, 1, 19-28.

Felsbildforschung auf West Neuguinea.

Paideuma, 1, 75-88.

Reisen in Celebes, 2 vols. Wiesbaden.

Versuch einer Anthropologie der Insel Celebes, 1. Die Toala Höhlen von Lamontjong. Wiesbaden.

Ergebnisse Naturw. Forschungen auf Ceylon, 4. Die Steinzeit auf Ceylon. Nachtrag zu unserer Arbeit über die Toalahöhlen von Lamontjong Celebes. Wiesbaden.

Recherches préhistoriques au Siam. L'Anthropologie, 63, $1-40$.

Ueber die Toala-Frage. Zeitschr. f. Rassenkunde, 1, 127-33.

Beitrage zur Prähistorie der Inseln Timor und Roti. Verh. Naturf. Ges. in Basel, 47, 1--59.

Ueber Spuren einer früheren weddide Bevölkerung auf der Insel Roti oder Rote bei Timor. Zeitschr. f. Rassenkunde, 7, 251-54.

Neue litochrone Funde im Inneren von Sumatra. Verh. Naturf. Ges. in Basel, 25, 97-111.

Sumatra. De Mijningenieur, 9, 235-43.

Kjökkenmöddinger und Palaeolithikum in Nord Sumatra. TAG, 48, 905-23.

Menschelijke skeletresten van Gol Ba'it, Sungai Siput, Perak, Maleische schiereiland. Mensch en Maatschappij. 
1949:

Speiser, F.

1938:

Stein Callenfels,

P. V. v.

1924:

1930:

1931:

1932a:

1932b:

1933a:

1934:

1936a:

1936b:

1938a:

1938b:

Stein Callenfels, P. V. v. and Noone, H. D. 1940:

Tindale, E. K.

1937:

Trattman, E. K. 1938:

Tweedie, M. W. F. 1942:

1953:

1955:
Human skeletal remains from Gol Ba'it, Sungai Siput, Perak, Malay Peninsula. Acta Neerlandica Morphologica et Pathologica, 6, 4, 1-25. Melanesien und Indonesian. Zeitschr. f. Ethn., $6,463-80$.

Het eerste palaeolithische werktuig in den Archipel. OV, 127-33.

Problems of the Stone Age in the Far East. Proc. of the 4th Pac. Science Congr., Java 1929, 375-78.

Note préliminaire sur les fouilles dans l'abri sous roche du Guwa Lawa à Sampung. Hommage Prem. Congr. Préhist. Extr. Orient, 16-32, Hanoi.

Die Aufgaben der japanischen Prähistorie im Rahmen der internationalen Forschung. Zeitschr. für Prähistorie: Shizengaku Zasshi, 4, 119-36.

Some early migrations in the Far East. Man, $32,283-84$.

De immigratie van de Papoea-Melanesoiden.

Mensch en Maatschappij, 9, 339.

Korte Gids voor de Praehistorische verzameling. An Excavation of three kitchenmiddens at Gua Kepah, Prov. Wellesley, Straits Settlements. Bull. Raffles Museum 1, 27-37.

The Melanesoid Civilizations of Eastern Asia, Ibid, 1, 41-51.

Het Proto-Toaliaan, TBG, 579-84.

Archaeologisch onderzoek in Celebes. TAG, 55, 138-44.

Report on an excavation in the Rockshelter Gol Ba'it near Sungai Siput (Perak). Proc. 3rd Congr. of Prehistorians of the Far East, Singapore, 119-25.

Relationship of the extinct Kangaroo Island culture with cultures of Australia, Tasmania and Malay. Rec. of the South Austr. Mus., 6, $39-60$.

Notes on some human teeth from Gua Bintang, Bukit Chuping, Perlis. Bull. Raffles Museum, 7, 116-19.

Prehistory in Malaya. Journ. of the Royal Asiat. Soc., 1-13.

The Stone Age in Malaya. Journ. Mal. Branch RAS 26, 3-90.

Prehistoric Malaya. Background to Malaya Series, 6, $1-43$. 
Verhoeven, Th. 1952:

1953:

Vaufrey, R.

1927:

Verneau, R.

1909:

1925:

Wastl, J.

1939:

Willems, W. J. A.

1939:

Winstedt, R. O.

1932:

Witkamp, W.

1920:

Wray, L.

1897:

1905:

Zwierzycki, J. 1926:
Stenen werktuigen uit Flores, Indonesië.

Anthropos, 47, 95-98.

Eine Mikrolithenkultur in Mittel- und West

Flores. Anthropos, 48, 597-612.

Découvertes d'industries préhistoriques à

Sumatra et dans la presqu'ile de Malacca.

L'Anthropologie, 37, 229-31.

Les crânes humains du gisement préhistorique de Pho-Binh-Gia. L'Anthropologie, 546-59.

Les recentes découvertes préhistoriques en Indo Chine. L'Anthropologie, 35, 47.

Prähistorische Menschenreste aus dem Muschel hugel von Bindjai-Tamiang in Nord Sumatra. Kultur und Rasse, 237-43.

Merkwaardige praehistorische schelpartefacten van Celebes en Java. Cult. Indië, 1, 181-85. The Prehistory of Malaya. Journ. Mal. Branch RAS, 19, 93-98.

'Kjökkenmöddinger' ter Oostkust van Sumatra. TAG, 37, 572-74.

The cave-dwellers of Perak. Journ. Anthrop.

Inst. Gr. Britain and Ireland, 26, 36.

Further notes on the cave-dwellers of Perak. Journ. FMS. Museums, 1, 13-15.

Een vondst uit de palaeolithische cultuurperiode in een grot in Boven Djambi.

De Mijningenieur, 7, 63-67. 


\title{
III. NEOLITHIC
}

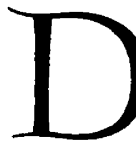

\author{
INTRODUGTION.
}

uring the period $1800-1850$ Neolithic stone tools began to be collected in the Museum of the Royal Batavia Society, Djakarta.135 The first recorded publication of these stone tools is G. E. Rumphius in 1705 who shared the popular belief that they were thunderbolts. 136 Subsequent publications include E. Swaving and W. Vrolik 1850,137 C. Leemans 1852, A. W. Kinder de Kamerq 1868, J. J. van Limborg Brouwer 1872 and C. H. Pleyte 1887.138 Some of these early publications include descriptions and illustrations. A paper on the Stone Age of Celebes was published by A. B. Meyer and O. Richter 139 in 1902. More recently general syntheses of the Stone Age of Indonesia and its relations with South East Asia have been published by R. Heine Geldern 140 and P. V. van Stein Callenfels. In the absence of a clear stratigraphy these surveys are based on the distribution of well-known types of stone tools, and on comparative linguistic evidence. Excavations have subsequently been carried out by van Heekeren in Java, and by van Stein Callenfels, A. A. Cense and van Heekeren in Celebes.

\footnotetext{
135 v. d. Hoop; '41, 20-165.

136 Rumphius; 1705.

137 Vrolik; 1850, 99-102.

138 Leemans; 1852, 106-18. Limborg Brouwer; 1872, 67-88. Pleyte; 1887, $35-46$.

138 Meyer und Richter; '02, 72-91.

140 Heine Geldern; '26, 51-53; '28, 809-43; '33, 543-619. '36, 32-36. '45, 136-42. Van Stein Callenfels; '26, 174-80.

Robert Heine Geldern, in spite of the limited knowledge of the neolithic period in Indonesia and the absence of nearly all stratigraphical data, made several attempts to get a broad survey of the structure of the various neolithic civilizations and their distributions, as well as to the epochs in which migrations took place. He based his study on comparative linguistics and used the deductive method based mainly on the geographical distribution of the stone tools and comparison with similar tools from Asia.

One of the merits of van Stein Callenfels (who passed away in 1938), is the foundation of a prehistoric section in the Djakarta Museum.
} 


\section{EXCAVATIONS.}

1. J ava.

A Neolithic dwelling site was excavated by the present writer at Kendeng Lembu, East Java in 1941. This site was discovered by W. van Wijland and J. Buurman in 1936. Agricultural work on the estates Kendeng Lembu and Pagger Gunung, lying south of Glenmore and between Djember and Banjuwangi, had revealed traces of Neolithic occupation. Many Neolithic workshops and settlements are believed to exist on these estates. The excavation which took place shortly before the outbreak of the war was never finished, and the finds and field notes were destroyed during the Japanese occupation. However, the main results have been recollected by the author, and are of sufficient importance to deserve publication.

The stratigraphy of the site was clearly discernible. An upper layer $50 \mathrm{~cm}$. thick contained Majapahit pottery (1300-1600 A.D.) and Chinese coins of the Kèpeng type, while a lower layer $30 \mathrm{~cm}$. thick contained a Neolithic habitation deposit.

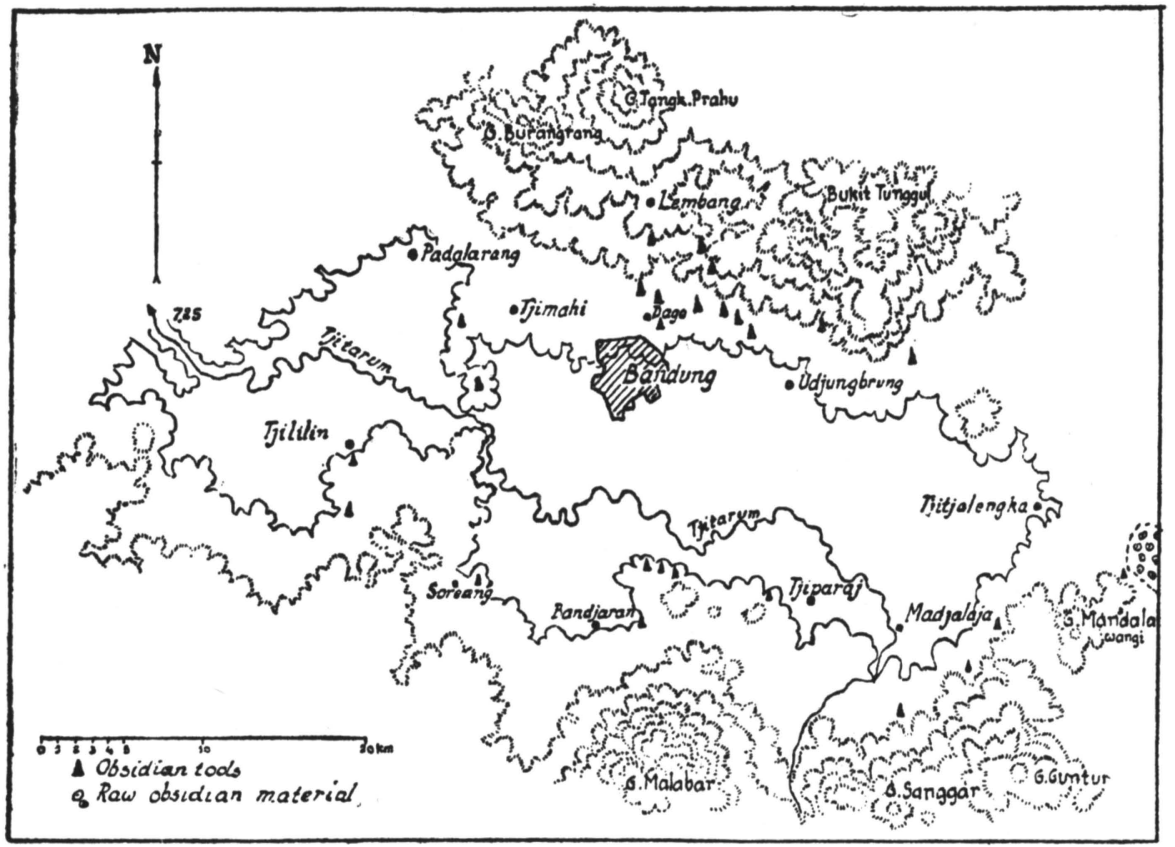

Fig. 21. Prehistoric sites with obsidian flakes and blades round a vanished lake near Bandung. 
The main classes of Artifact recovered from this deposit were Quadrangular Adzes, and undecorated Neolithic potsherds. ${ }^{141}$ All the stone tools were made of grey-blue shale. They were found in all stages of manufacture showing that this was a workshop site. Other implements included a cylindrical grinding stone with eight facets, two stone saws, and long heavy stone flakes with one cutting-edge, probably to be classified as knives.

Large quantities of undecorated pottery were found. Some of these were restored by Buurman. They appeared to be simple hand-made vessels, with a marked carination and rolled rims.

2. Ce le bes.

Sikendeng.

In 1933 a trial excavation was made by A. A. Cense at Sikendeng where an Amaravati Bronze Bhudda had previously been found. This site is on the right bank of the Karama River, West Central Celebes. During this excavation a few Quadrangular Adzes and many potsherds were discovered. Subsequent excavations by van Stein Callenfels at the same site resulted in the collection of a large quantity of Quadrangular Adzes and undecorated potsherds. 142

\section{Kalumpang.}

A further Neolithic settlement site was revealed during road making at Kalumpang, $93 \mathrm{~km}$. up-stream on the Karama River. The site was first excavated by van Stein Callenfels in 1933143 and subsequently by van Heekeren in 1949.144

The site is on a flat-topped hill (Kamasi Hill) approximately 14 metres above the river-level. The implements were recovered without stratification below the humus. On typological considerations, I have divided these into three classes.

Group 1. Shouldered and side-hafted Adzes or Axes.

Most of the specimens are manufactured from chert or slate. All specimens are flaked pebble-tools and are considered to have Hoabinhian

141 The thousands of potsherds might be taken as indications to the existence of a neolithic settlement.

142 Van Heekeren; '51a, 35. Van Stein Callenfels; '51, 6.

143 Van Stein Callenfels; '50, 49-53. '51, 82-97.

144 Van Heekeren; '51a, 26-48. 
affinities. The shouldered axes show no trace of polishing and are only worked on one flaked surface. The side-hafted axes have a polished cutting-edge and a lenticular cross-section. They are made with a crude lateral shoulder or lug where the butt meets the blade. This feature was presumably used in attaching a wooden haft. A violin-shaped adze without or with little polished surface is probably related to the crude shouldered axes. (Pl. 47).

\section{Group 2. Quadrangular Adzes.}

These tools are quite numerous at the site, and differ in workmanship and raw material from the axes of group I. They are made of greyblue shale, and range from $81 / 2 \times 5 \mathrm{~cm}$. to $2.2 \times 0.9 \mathrm{~cm}$. in size.

Stone rings of various sizes, a stone bark-cloth beater, together with polished spear-heads of slate were also found at this site; they should be associated with this group, though stone bark-cloth beaters of the type found are still in use in this region.

\section{Group 3. Specimens assigned to the Early Metal Age.}

This group includes small stone knives with polished cutting-edges, and polished tanged arrow-heads. These implements should be assigned to a later horizon of influences, since comparable specimens are known from Early Metal settlements in Cambodia. (Pl. 37, 38).

$95 \%$ of the pottery from this site is undecorated and this as well as the simple ornamented potsherds may be assigned to the Neolithic. The highly decorated pottery which makes up the remainder of the collection is from a later horizon. The decoration on this pottery with rectangular figures, squares, spirals, circlets and rosettes resembles those from the upper layers from the Samrong Sen collection in Cambodia.

Fragmentary human remains were found on the site; the fauna included a small wild pig (Sus celebensis) and a domesticated variety (Sus vittatus) which is not native to Celebes.

\section{Dating.}

It has been stated before that all finds were made in the shallow surface layer (from 11 to $63 \mathrm{~cm}$.) of the hill. This layer consits of a drab, compact clay composed of volcanic material and mixed with marl. It contains augite in various conditions of weathering. This layer gave therefore the impression of being very young geologically. According to W. F. van Beers, who analyzed the soil samples, it could not be older 


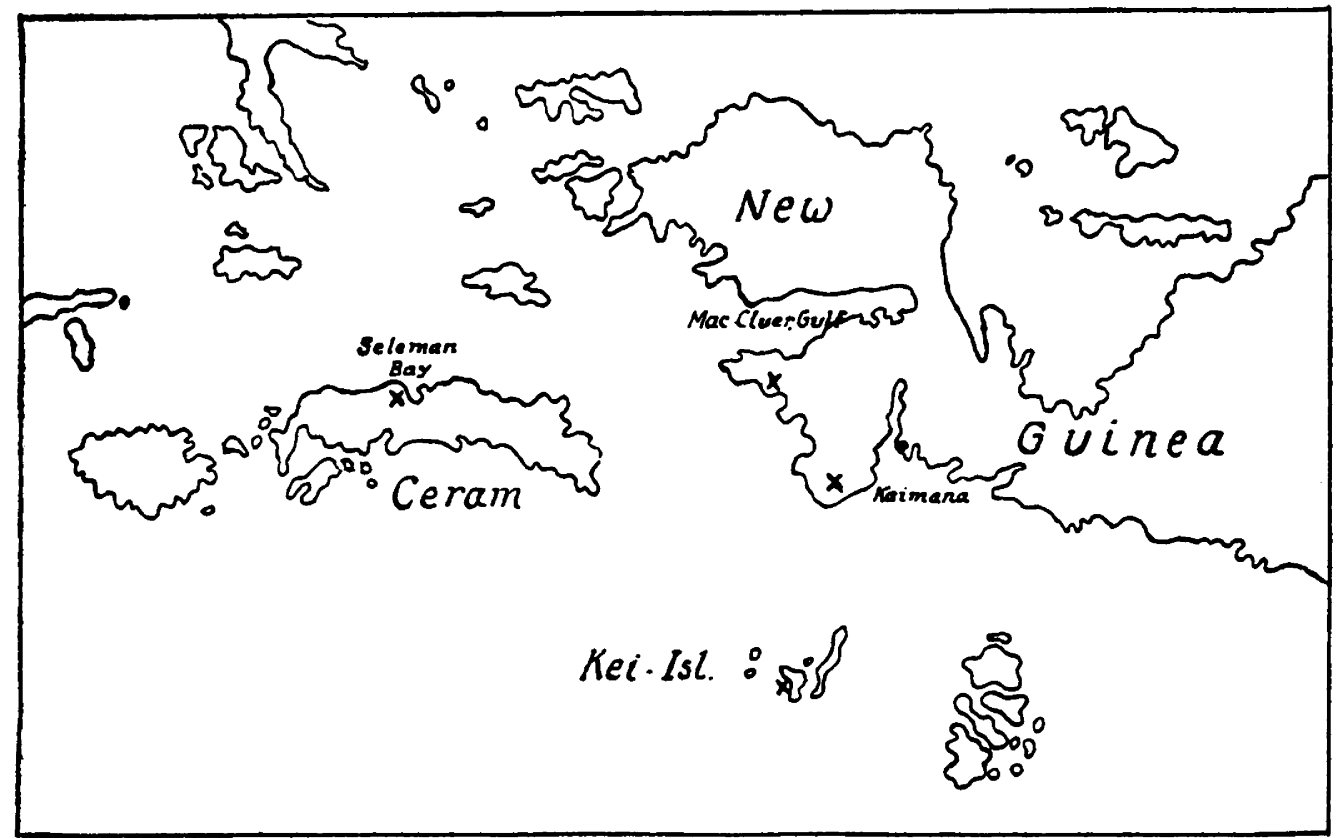

Fig. 22. x Rock-painting sites in East Indonesia and New Guinea.

than one thousand years at the most. In this instance we may speak of a serious retardation mainly caused by isolation of the Kalumpang Peoples.

2. NEOLITHIC SURFAGE FINDS.

Sumatra:

Westcoast $\quad$ - A few large and small Quadrangular Adzes; Pick Adzes made of agate and black fine-grained volcanic rock.

Benkulen

- A few Quadrangular Adzes and Pick Adzes; among them one of a long and narrow type. The tools are made of agate and fine-grained basalt. (Pl. $36)$.

Palembang - A fair number of Quadrangular Adzes and Pick Adzes. A neolithic workshop near Bungamas between Lahat and Tebingtingih. The implements are made of red brown, grey or brown rock and lustrous chalcedony. 
Lampongs _ - Numerous well-shaped Quadrangular Adzes, many of which made of semi-precious stone like chalcedony, jasper and silicified limestone. Collected by E. H. S. Schlegtendahl and now on display at the Djakarta Museum.

Assam $\quad-$ Two Round Axes with oval cross-sections and more or less rounded necks.

Java:

Bantam - Numerous Quadrangular Adzes made of agate, jasper, silicified limestone; Pick Adzes and some armrings of chalcedony.

Djakarta - Numerous Quadrangular Adzes and Pick Adzes, and Tangerang made of chalcedony, agate, jasper and black finegrained basalt; a fair number of armrings of chalcedony. Grinding stones with smooth surfaces and prismatic sections. Unfinished adzes made of chalcedony, agate and volcanic rock.

Bogor _ - Many Quadrangular Adzes, Pick Adzes, unfinished adzes. Armrings and polishing stones from neolithic workshops at Pasir Guda Estate. 145

Tjibadak - A stone bark-cloth beater made of a light-grey stone: $127 \times 46 \times 63 \mathrm{~cm}$. Quadrangular Adzes made of silicified limestone and chalcedony.

Cheribon - Numerous Quadrangular Adzes, Pick Adzes and half-finished adzes, stone armrings, a cylindrical grinding stone with facets, $159 \mathrm{~mm}$. length. Most of the tools are made of chalcedony and jasper.

Priangan - Numerous Quadrangular Adzes and Pick Adzes, one of them measuring $430 \times 91 \times 30 \mathrm{~mm}$; rings of chalcedony and jasper and unfinished rings, found near Tasikmalaja by C. Franssen.146

Pekalongan - - A few Quadrangular Adzes and Pick Adzes; stone rings of chalcedony.

Banjumas - A few Quadrangular Adzes and Pick Adzes and grinding stones. Workshops in the Karangbolang mountains near Karanganjar.

145 Franssen; '41b, 531-44.

146 Franssen; '41a, 132-39. 


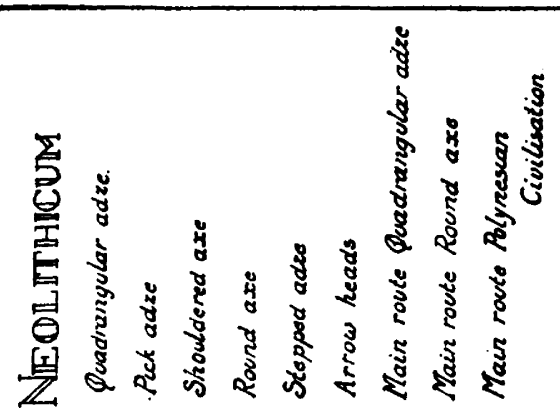

$000004\{\vdots !$
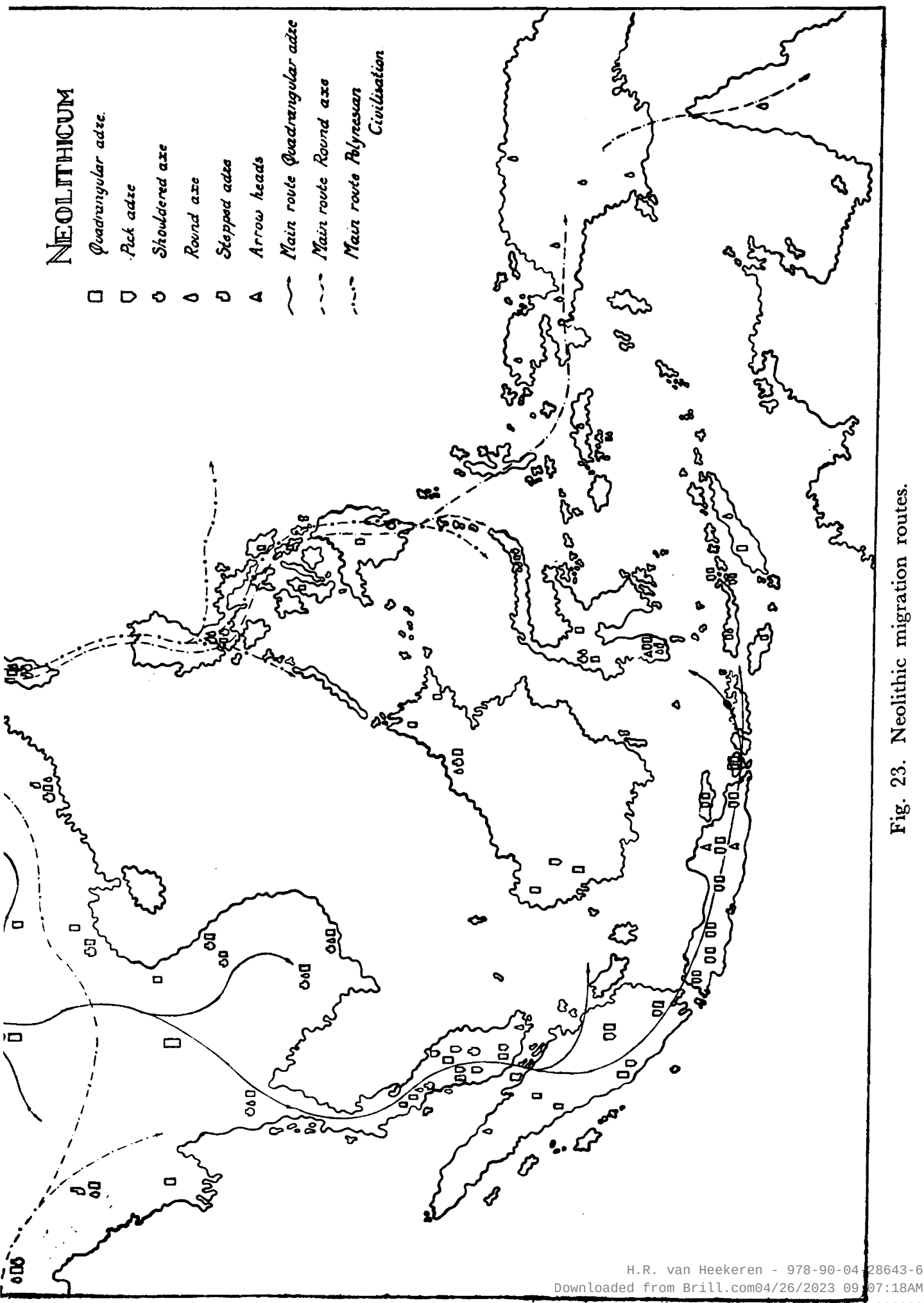
Semarang - Quadrangular Adzes and two Pick Adzes of semiprecious stone.

Kedu - Many Quadrangular Adzes and a few Pick Adzes.

Jogjakarta - Numerous Quadrangular Adzes, a few Pick Adzes, rings made of limestone. Polishing stone, $130 \mathrm{~mm}$. in length.

Surakarta - Numerous finished and unfinished Quadrangular Adzes, concave-based (winged), bifacially chipped arrow-heads, generally made of silicified limestone. Most of the tools from Wonogiri and Punung. No Pick Adzes.

Madiun

- Numerous Quadrangular Adzes and stone arrowheads. Most of these from the workshops of $\mathrm{Pu}$ nung. (More than hundred workshops are known from Punung). One bracelet of chalcedony. No Pick Adzes.

Surabaja $\quad-$ A few Quadrangular Adzes made of volcanic rock and chalcedony. A few Pick Adzes.

Madura _- A few Quadrangular Adzes made of basalt.

Malang _ A fair number of Quadrangular Adzes and Pick Adzes and a few Proto-neoliths. The tools are made of chalcedony and black basalt.

Besuki

- Numerous Quadrangular Adzes and Pick Adzes and unfinished adzes. Long gouges with circular cross-section. Small and slender gouges with tapering sides from the butt to the distal ends; uncommonly small chisels; roof-shaped adzes. Most of the tools are made of black or grey and green rock. Workshops and dwelling sites at Kendeng Lembu Estate, Glenmore.

Bali

- Numerous Quadrangular Adzes and Pick Adzes of the Besuki type, some adzes with lentoid crosssections. Large and small gouges with semi-circular cross-sections. Polishing stone with facets, $104 \mathrm{x}$ $36 \times 17 \mathrm{~mm}$.

Lombok - None.

Sumbawa - None.

Flores

- A few Quadrangular Adzes and a few Round Axes with oval cross-sections.

Adonare $\quad$ - A few Quadrangular Adzes. 


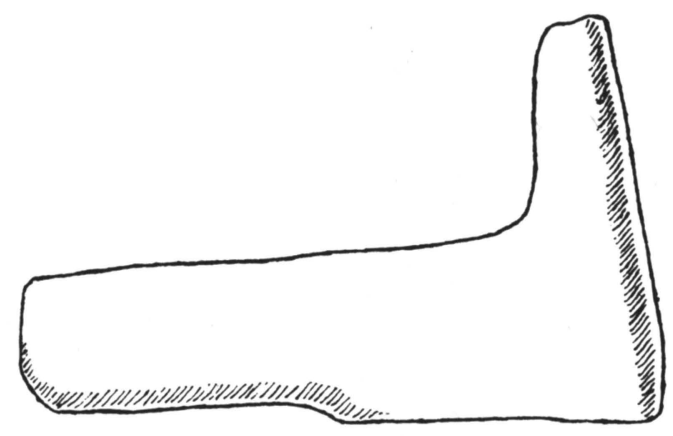

$a$
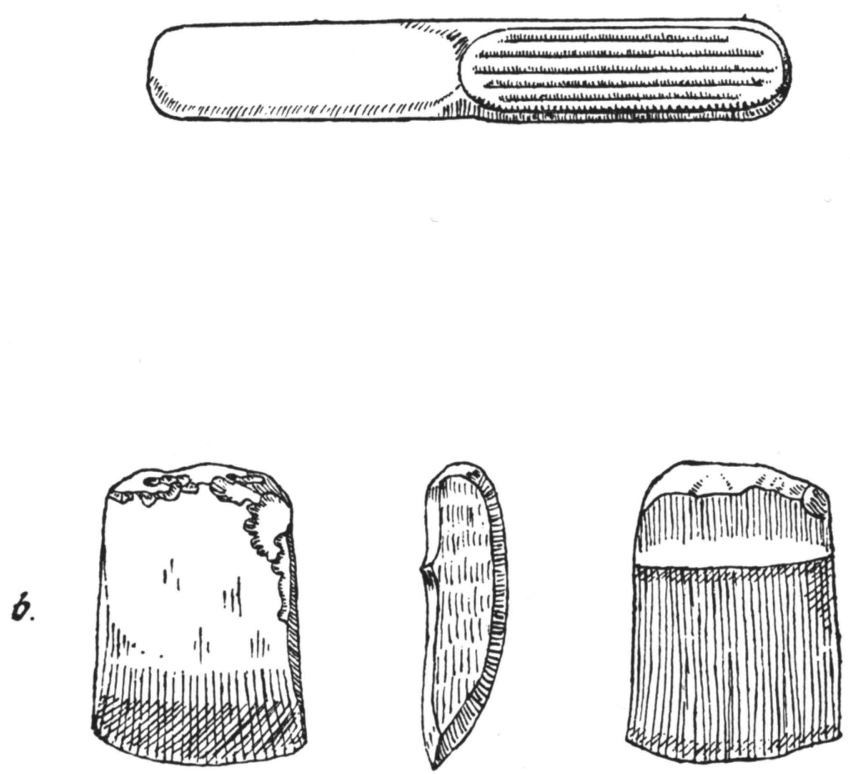

Fig. 24.

a. Neolithic „horned" Bark-Cloth Beater, West Borneo.

b. Neolithic Stepped Adze, Minahassa, North Celebes.

Leti

Tanimbar

Moluccas

Solor

Borneo
- A few Round Axes.

- A few Round Axes.

- Some Quadrangular Adzes; uncommonly small chisels. Roof-shaped adzes and a few Round Axes.

- A few Quadrangular Adzes.

- A few Quadrangular Adzes, one Pick Adze in the western part; one horned bark-cloth beater (Fig. 24a) (of the so-called Philippine type) at Ampah, 
South and Eastern district; ${ }^{147}$ one Round Axe with oval cross-section and pointed neck from Pontianak (189 × $52 \times 30 \mathrm{~mm}$.); a few roof-shaped adzes.

Celebes

- Many Quadrangular Adzes, a few Pick Adzes, three Stepped Adzes from Tondano and one item from the southwest part, one Stepped Adze from the Minahassa; One Round Axe from the Minahassa, one highly polished Round Axe made of glossy black volcanic rock, blunt-pointed buttend and oval cross-section ( $154 \times 57 \times 23 \mathrm{~mm}$.), Sario River, Manado; one Round Axe from Pangkadjene and one Round Axe from Bulukumba. Minango Sipakko (Karama River) discovered in 1949 by van Heekeren: Unstratified river bank site; eleven stone axes with oval cross-sections, made of chert; one horned bark-cloth beater of the Philippine type; associated with polished red ware, pottery with rectilinear incised decoration and stamped circle decoration.

Sangir Island - One Quadrangular Adze made of black volcanic rock $(83 \times 41 \times 14 \mathrm{~mm}$.). South part of the island. Found by $\mathrm{Dr}$ Blankhart. One highly polished Round Axe made of dark-green rock ( $75 \times 45 \times$ $22 \mathrm{~mm}$.). Traces of hammer-dressing visible. Dumahang. Found by Dr Blankhart.

Talaud Island - One Round Axe with pointed butt-end and bilevelled cutting-edge; made of Tridacna shell (105 x 54 x $29 \mathrm{~mm}$.); oval cross-section. Ennawira, south part of the island. Found by $\mathrm{Dr}$ Blankhart.

One Round Axe with pointed butt-end and bilevelled cutting-edge and oval cross-section; made of Tridacna shell $(84 \times 40 \times 20 \mathrm{~mm}$.) Rainis. Found by Dr Blankhart.

One Quadrangular Adze made of poor basalt, dull-grey (111 x $45 \times 21 \mathrm{~mm}$.) Rainis. Found by Dr Blankhart.

147 V. d. Hoop; '35, 468-70. 
One fragment of a Pick Adze with semi-circular cross-section, made of dark-brown volcanic rock (73 x 56 × $33 \mathrm{~mm}$.) Rainis. Found by Dr Blankhart.

One Quadrangular Adze, made of glossy black volcanic rock. (64 × $41 \times 19$ mm.) Rainis. Found by Dr Blankhart.

One oval adze with sharp sides; uni-levelled cutting-edge, made of light-brown volcanic rock (102 x 48 x 24 mm.) Essang. Found by Dr Blankhart.

\section{NEOLITHIC TRADITIONS IN INDONESIA.}

In many places in the Archipelago pottery is still hand-made. A. C. Kruyt 148 relates that among the Western Toradjas in Central Celebes the technique of shaping pottery is very little known. The raw clay is fetched and planted in the ground where it is believed to grow on its own accord. There exist several regulations and prohibitions pertaining to the making of pots. For instance, it is not allowed to praise the women who are exclusively in charge of the work, because it is believed that the pots will break during the baking. The clay is kept in a cool place and covered with fresh banana leaves. The next day, small portions of clay are pounded on a flat stone with a round stone, sprinkled with water every now and then, and cleaned and kneaded into balls. The ball of clay is then moulded into the form of a pot or bowl by the thumb and the other fingers, the thumb pressing the wall outward from within, the fingers modelling the pot into shape at the outside. The pot is then finished by keeping a round, flat stone against the inside and by beating with a wooden bat till the clay has gained the same thickness everywhere. During the process the pot is turned over and over again. Finally the edge of the mouth is curved outwards with the fingers so as to obtain a turned down rim or neck.

Evidently, the neolithic peoples of Indonesia made their clothes from beaten bark (stone bark-cloth beaters have been found in Neolithic sites), and this procedure still flourishes in the most remote districts, for instance in Central Celebes. Kruyt 149 has collected important information concerning this industry among the Toradja tribes. It appears that not

148 Kruyt; '38, 439-45.

149 Kruyt; '01, 139—91. Kennedy; '34, 229-43. 
all kinds of trees produce the proper bark, but only some wild-growing species (Trema amboinensis, Artocarpus blumei, Antiarsis Toxicaria, Sloetia minahassae, Ficus mulberry, Ficus sp., Urostigma sp.), whilst one species, the papermulberry Broussonnetia papyrifera, is especially cultivated because it produces a suitable, white bark. The tree is ringed and the bark stripped off. The hard outer surface is removed and the innerbark then folded and sometimes cooked, wrapped up in palm leaves and fermented for one to three days till the fibres are soft enough to be easily beaten. The stripes are usually half a metre long by ten centimetres wide and are laid upon each other to be felted together. The beating is done with wooden or stone beaters on a wooden board. The stone beater is a rectangular piece of stone, especially of serpentine, provided with grooves on both faces. Encircling the object is a wide groove to fit the springy rattan string by which the tool is hafted to a rattan grip. When the bark has been crushed sufficiently, the pieces (fuya $=$ tapa) are wind-dried on slats and afterwards treated with the juice of the ula fruit (Strychnos ligustrina). The dried fuya is hard, but after having been folded, it is beaten to flexibility with clubs. Sometimes ornamental designs are beaten into the fuya with wooden or stone stamps. All the work pertaining to the manufacture of bark-cloth is done by women.

Near the smaller tributaries of the Koro and Pakawari Rivers, there occur banks of serpentine which produce the material for the beaters. The stone is quarried on the spot and is either traded in its crude form or completely finished for use. When finished, the beaters are cooked with buffalo beef or pork to ensure their strength. The method for fuya preparation was probably also employed during Neolithic times throughout Indonesia. The excavations of the Neolithic site at Kalumpang yielded a stone bark-cloth beater which matches in detail the bark-cloth beaters still used at present.

\section{NEOLITHIC TOOLS.}

Polished and flaked stone tools and ornaments ascribed to the Neolithic in Indonesia may be divided into three classes and referred to three different culture complexes. This classification is summarised below and the geographical distribution of the different tool types in Indonesia, and in South East Asia is briefly described in each case.

1. The $Q u a d r a n g u l a r$ Ad.ze Culture.

The majority of the Neolithic cutting tools in Indonesia may be 
classified as Quadrangular Adzes (Pl. 34), and certain other classes of tools such as stone rings or quoits (Pl. 41) and bark-cloth beaters also (in most cases) may be regarded as belonging to the same culture complex. The geographical distribution of the Quadrangular Adze Culture is limited to Indonesia, the Malay Peninsula, Siam, Indo-China and parts of South China; and the presence of these tools in Indonesia should be ascribed to a wave of migration from the Asian continent between the second and first millennium B.C. Certain specialized types were developed in Indonesia, some of which were in use in historic times and may still belong to the native culture in the remoter parts of Indonesia. The Quadrangular Adze has the widest distribution of any Indonesian Neolithic implement. The distribution of these tools and of the specialized varieties described below suggests that Western Indonesia was the primary area of immigration. The typical Quadrangular Adze is square or oblong in shape and has a single levelled cutting-edge; its cross-section is either rectangular, square, quadrangular or an equilateral trapeze. The tool is blocked out by flaking, and then highly polished. Many specimens suggest that a small stone saw and coarse-grained sand were also used to cut out the tool.

The most common specialized tool developed in the Quadrangular Adze Culture is the Pick Adze. (Pl. 35). This tool is probably related to the Beaked Adze of the Malay Peninsula, and has a wide distribution in Western Indonesia. The typical Pick Adze has a flat lower surface and a longitudinal or pentagonal cross-section. The tools are highly polished on all surfaces. Pick Adzes and other Quadrangular Adzes in South Sumatra and West Java are frequently made of semi-precious stones such as translucent serpentine, agate, and chalcedony. The use of these semi-precious stones, and the uncommon size of some specimens which show no traces of use, suggest that they may not have been intended for use as implements. Many specimens from Central and South Sumatra, and a few West Javanese specimens are characterised by lateral sides tapering from the butt to form a narrow cutting-edge (Pl. 36). A specialized East Javanese Pick Adze is made from a lustrous fine-grained basalt. This variant is characterized by a semi-circular cross-section, and generally has a cutting-edge facetted from both sides of the upper face (Pl. 35c).

In the Surakarta and Madiun Residences the Pick Adze does not occur. The silicified limestone of these regions, though used for making adzes and arrow-heads, may have been found unsuitable for this specialized tool type. 
Other tool varieties found in Indonesia are indicated below with their provincial areas of distribution.

a. Shield-shaped Adze.

This tool has a convex upper surface and a concave lower surface. Its distribution is confined to Malaya, Java, Sumatra and Bali.

b. Stepped Adze (Fig. 24b).

Tweedie 150 describes this tool as follows "Stepped Adze: in which the thickness of the tool is abruptly diminished along a line near (and parallel) to the butt, forming a butt which presumably facilitated hafting". The distribution in Indonesia is confined to Celebes, a few specimens being found in Central and North Celebes and one specimen in South Celebes. These tools are part of the Stone Age equipment in the Philippines and East Polynesia.

c. Shouldered Adze.

Two varieties of this tool are now distinguished: a crude shouldered adze with Hoabinhian affinities, and the highly polished shouldered adze of the Indo-Chinese Neolithic also known from Northern Annam in Proto-Historic times.

Only the former variety is found in Indonesian collections.

The Indonesian shouldered adze is a pebble tool and is only worked on the upper surface. The butt-end of the implements is flaked to form a crude tang, and no or little polishing is used in the process of manufacture. One variant of this implement is the laterally tanged adze. These not or little polished shouldered adzes are also known to occur in Tonkin, Southern China, Taiwan, Botel Tobago, the Philippines and Japan. A highly polished form is known in Eastern Polynesia.

d. Bracelets of stone and shell.

A number of stone bracelets of different types have been found in Indonesia. Two examples deserve mention. At Krai (Surakarta, Java) shell bracelets were recovered by G. H. R. von Koenigswald in association with Quadrangular Adzes (Pl. 42) and shell beads. Chalcedony and jasper rings and bracelets were collected by Franssen 151 near Tasikmalaja, West Java, and though it has been suggested that these specimens may belong to the Proto-Historic period, this has not yet been determined.

150 Tweedie; '53, 69-73.

151 Franssen;' '41a, 132-39. 
Shell bracelets are still made by the Ifago and Igorot of Northern Luzon. Beyer has recorded the process of manufacture as follows: "holes (are) bored through the very hard Tridacna shell with drills made of a rather soft wood, the actual cutting of the shell being done by the fine sand which was constantly poured around the point of the drill. These wooden drills were of the common 'pump-drill' type in which the drill is operated by a cross-bar with cords and has a fly-wheel in the centre, turning first one way and then the other as the cross-bar is pulled down. Among the Moros and other peoples in Mindanao and Sulu, drill-points of wood, bone and metal have also been in use".152

e. Roof-shaped adzes. (Pl. 40).

These tools have sharply sloping sides and arched upper surfaces. Some specimens are found with narrow necks.

f. Miniature chisels.

g. Elongated gouges. (Pl. 39).

These tools have semi-circular or triangular cross-sections. Some varieties are equiped with narrow cutting surfaces to which the sides converge.

All these types are found in the Besuki area (East Java) and in Bali. Roof-shaped adzes and miniature chisels also occur in Northern Borneo, the Moluccas, Ceram and Tanimbar. The typology of these implements suggests that they form part of the Quadrangular Adze Complex in Indonesia. Miniature chisels are well-known from Neolithic associations in the Malay Peninsula. However, roof-shaped adzes and cylindrical gouges also form part of the equipment of the East Polynesian Stone Age presumably of a more recent date, and the associations of these tools in Indonesia must be regarded as uncertain.

No direct racial evidence concerning the authors of the Quadrangular Adze Culture was thus far obtained, but it has been suggested by Heine Geldern $\mathbf{1 5 3}$ that it is connected with the migration of the fair-skinned and wavy-haired Austronesians or Malay-Polynesians into the Archipelago; the distribution of the Quadrangular Adze Culture seems approximately to coincide with that of the Austronesian languages. Owing to its enormous dispersion the influences of this culture

152 Otley Beyer; '48, 88.

153 Heine Geldern; '45, 136. 
are noticeable not only throughout Indonesia, but also so far as Madagascar in the West and Easter Island in the East.

Heine Geldern's suggestion has been accepted a.o. by v. d. Hoop, van Stein Callenfels and van Naerssen. It seems to me, however, rather speculative to identify culture waves or migrations with the spread of a language. Heine Geldern's suggestion badly needs archaeological confirmation. He also attributed 'an older' megalithic complex to the Quadrangular Adze Culture on the basis of its geographical distribution. The megaliths in question comprise stone-paved roads, stone terraces, walls, stone spirit seats, menhirs, circles, pyramids, monumental ancestral images, all of which can be traced throughout the area from Assam to Eastern Polynesia. The megaliths were erected as memorials for sacrificial ceremonies or in behalf of the dead. The occurrence of Neolithic megaliths of this kind in Eastern Polynesia may be considered as testimony for this statement, but on the other hand no Neolithic megalithic remains have as yet been encountered in Indonesia and Indo-China.

It has been suggested that the dog and pig were kept partly for consumption and partly for sacrificial purposes; teeth of dogs and pigs in association with Quadrangular Adzes were found in South China, Cambodia and Central Celebes. There is no evidence as yet concerning the use of cattle or buffalo in Neolithic times. The fowl (Gallus gallus gallus) was probably imported in a semi-domesticated form in Indonesia by way of the Philippines in Late Neolithic times. 154

There are some indications that the authors of the Quadrangular Adze Culture, prior to their arrival in Indonesia, knew how to cultivate rice; a Neolithic site in China yielded the special forms of reaping knives, probably used in harvesting rice, and corresponding in shape with the modern iron knives in South East Asia. Some Neolithic potsherds found in a Neolithic site in South China showed impressions of rice (Oryza sativa) 155

\section{The Round Axes.}

The Round Axe (Pl. 43) is characterised by a lenticular, oval or round cross-section, a bi-levelled curved cutting-edge and a more or less pointed or rounded neck. First roughly flaked into shape, this tool is generally smoothed down by hammer-dressing and then polished. There are also specimens which are simply finished by hammerdressing. Accor-

154 Stresemann; '39, 312-425.

155 Edman, '29, 363-65. 
ding to MacCarthy, 156 the distribution of the former types is more limited than that of the latter.

The first Round Axe with a pointed butt was recorded from North Celebes at Sonder by the late Major Waworuntu. In the northern part of Borneo, too, several Round Axes have been found. For the rest, oval and Round Axes occur throughout Celebes. Museums in Indonesia and in foreign countries display Round Axes from the Moluccas, Leti, Tanimbar and Flores, and also some examples from the Eastcoast of Sumatra. Recently Dr D. M. Blankhart reported three Round Axes from Sangir Island and two examples from Talaud Island, two of which were made from Tridacna shell. Dr Blankhart's discovery has taken place in an area so far unexplored and is, therefore, of prime importance. The Round Axes from Manado, Talaud and Sangir are indistinguishable from those of New Guinea, where similar axes are still manufactured and used.

The widespread occurrence of Round Axes in Japan 157 is well-known and the artifacts also occur in the Philippines. Judging by the nature of their distribution on the Asiatic Continent and in Indonesia, both van Stein Callenfels and Heine Geldern assumed that the Round Axe Culture did not enter Indonesia directly from India and Malaya, but, what is more probable, from Japan. F. Speiser 158 states that the representatives of this culture were Neo-Melanesians and in this connection the Buka are mentioned who introduced the plank-boat and the so-called coiled pottery, but it seems that the conclusions are based on imperfect information. For the time being, we are not certain at all who were the authors of the Round Axe Culture, the pattern of which is quite unknown.

\section{Stone Arrow-heads.}

The occurrence of Neolithic arrow-heads in Central Java and South Celebes is rather curious. The implements under discussion are triangular projectile stone points with concave (winged) or in some instances convex base ( $\mathrm{Pl} .44,23, \mathrm{j}, \mathrm{k}, \mathrm{l}, \mathrm{m}, \mathrm{n})$. Nearly all artifacts from Java are

\footnotetext{
156 MacCarthy; '40, 40-43.

157 Groot; '51.

158 Speiser; '38, 463-80.

The Buka are of medium stature, intensely black and having a beak-like nose; their lips are not so thick as those of the Palae-Melanesians. According to Speiser they introduced the Round Axe in New Guinea and at a later date in the Melanesian islands where they still live on Buka, Nisan, Bougainville, New Ireland and the northern part of the Solomons.
} 
made of silicified limestone and betray a far-advanced technique. The majority are chipped on both surfaces. Their measurements vary considerably, but most implements are about six centimetres in length. Small examples of one and a half centimetres length or less, are decidedly rare. It is supposed that they were employed for bird hunting. Of the whole of these arrow-heads I have seen on Java, only one piece had barbed sides. This item is in Houbolt's collection in Bandung. Stone arrowheads have been found in Java in the Sampung Cave near Ponorogo and in other caves near Bodjonegoro and Tuban and numerous pieces were collected in the neolithic workshops round Punung in Central Java, but they are entirely absent in the most western and eastern part in Java.

The upper layers of the Toale caves in Southern Celebes yielded many such stone arrow-heads; in the same stratum also potsherds occurred. In shape and workmanship they differ in several respects considerably from those found in Java. They are smaller and flatter, and generally chipped on one face only. Moreover, the sides are frequently barbed. (Pl. 45). Since no such implements have been encountered on the Asiatic continent, but on the other hand they are frequent in Japan and the Philippines, we may take it that these arrow-heads were introduced by way of the last mentioned islands, as has been already suggested both by van Stein Callenfels and Heine Geldern.159

150 Heine Geldern; '45, 136. 


\section{REFERENCES AND SELECTED BIBLIOGRAPHY.}

Abdul-Azis, Engku 1932:

Andersson, J. G. 1923:

1934:

Arne, F. J. 1925:

Beyer, H. Otley 1947:

1948:

1951:

i952:

Bylin, Margit

1932:

Carthy, F. D. M[ai; 1940:

1949:

Colani M.

1927:

1930:

1932:

Condominas, $\mathbf{G}$. 1952:

Eberha:d, W. 1950:
Neoliths from Jehore. Journ. Mal. Branch RAS, 10.

An early Chinese culture. Bull. Geol. Surv. China, 5, 1-68.

Children of the Yellow Earth. Studies in Prehistoric China. London.

Painted stone age pottery from the Province of Honan. Palaeontologica Sinica DI.

Outline Review of Philippine Archaeology by islands and provinces. The Philippine Journ. of Science, 77, 205-373.

Philippine and East Asian Archaeology. Nat. research council of the Philippines. Manilla, 29, $1-130$.

A contribute to Van Stein Callenfels. Journ. of East Asiatic Studies. Manilla, 1, 1, 77-81.

Notes on the Archaeological work of H. R. van Heekeren in Celebes and elsewhere (19371950). Journ. of East Asiatic Studies. Manilla, $1,3,1-17$.

Notes sur quelques objets néolithiques trouvés à Formosa. MFA.

Comparison on the Prehistory of Australia with that of Indo China, the Malay Peninsula and the Neth. East Indies. Proc. 3rd Congr. of Prehistorians of the Far East.

The prehistoric cultures of Australia. Austr. Med. Publ. Co. Ltd, 19, 305-319.

L'Age de la pierre dans la Province de Hoabinh (Tonkin). Mém. Serv. géol. Indo Chine, 30, $299-422$.

Recherches sur la Préhistoire Indo Chinois. Mém. Serv. géol. Indo Chine, 30, 299-422.

Le Protonéolithe. Praehistorica Asiae orientalis, 93-95.

Le lithophone préhistorique de Ndut Lieng Krak. BEFEO, 45, 2, 359-393.

A history of Chine. Berkeley and Los Angelos. 
Evans, I. H. N. 1913:

1928a:

1928b:

1929:

1930a:

1930b:

1931:

Edman, G. and Söderberg, E. 1929:

Finn, D. J. 1932:

Fischer, H. Th. 1937:

1939:

Franssen, C. J. H. 1941a:

1941b:

Groot, G. J.

1951:

Harrison, $T$.

1951:

Heanly, C. M. 1928:

Heanly, C. M. and Shellshear 1932:

Heekeren, H. R. van 1932:

1951a:
On a collection of stone implements from the Tempassuk District British North Borneo. Man, 28, 25-26.

On a find of stone implements associated with pottery. Journ. Fed. Malay St. Mus., 12, 5, 133-135.

Further notes on stone implements associated with pottery. Journ. Fed. Malay St. Mus. 12, 5, 143-144.

Further notes on a find of stone implements with pottery. Journ. Fed. Malay St. Mus., 12, 7, 175-176.

On a stone spear-head from Kelantan. Journ. Fed. Malay St. Mus., 15, 1, 1-3.

Malayan types of stone implements in India, Burma and the Andamans. Journ. Fed. Malay St. Mus., 15, 1, 9-11.

A note on beaked stone adzes. Journ. Fed. Malay St. Mus., 15, 2, 67-68.

Auffindung von Reis in einer Tonscherbe aus einer etwa fünftausendjährigen Chinesische Siedlung. Bull. Geol. Soc. China, 8, 363-365. Archaeological finds on Lama Island near Hongkong. Hongkong Naturalist.

Reispflücken und Reisschneiden in Indonesien. IAFE, 34, 83-104.

Das Indonesische Reismesser ausserhalb Indonesiens. Paideuma, 1, 147-152.

Over het voorkomen van prehistorische steenen ringen op Java. Natuurw. Tijdschr. v. Nederl. Indië, 101, 5, 132-139.

Prehistorische werktuigen uit de omgeving van Leuwiliang in de residentie Buitenzorg. TBG, 81, 531-544.

The Prehistory of Japan. New York.

Note on some neolithic implements from

Borneo. Man, 51, 21-23.

Hong Kong Celts. Bull. Geol. Soc. of China, 7, $3-4$.

A contribution to the Prehistory of Hongkong and the new Territories. Praehistorica Asiae orientalis, $63-76$.

Gepolijste steenen bijlen in Besoeki. Djawa, 12, 203-206.

Rapport over de ontgraving te Kamasi, Kalumpang, West Central Celebes. OV, 1949, 26-48. 
1951b:

1951c:

1952:

1955:

Heine Geldern, $\mathbf{R}$. 1926/27

1928:

1931:

1932:

1936:

1945:

1946:

Hoop, A. N. J. Th. à Th. v. d.

1935:

1938:

1941:

Hornell, J.

1920:

1943:

Kennedy, Raymond 1934:

Kern, $\mathbf{H}$. 1889:

Koenigswald, G. H. R. von 1953:

Krom, N. J. 1926:

Kruyt, A. C. 1901:
Penjelidikan Prehistori. Sekitar Penjelidikan Purbakala.

Korte Mededelingen. Getrapte dissel in Zuid Gelebes. TBG, 84, 510.

Note on H. Otley Beyer's "A Tribute to Van Stein Callenfels". Journal of East Asiatic Studies, 1, 3, 141.

Prehistoric Life in Indonesia. Djakarta.

Die Steinzeit Südostasiens. Sitzungsberichte der Anthr. Ges. Wien, 51-53.

Ein Beitrag zur Chronologie des Neolithikums in Südostasiens. Festschr. P. W. Schmidt, Wien, 809-843.

Ausleger und Doppelboote im inneren HinterIndien. Der Erdball, 5, 373-380.

Urheimat und früheste Wanderungen der

Austronesier. Anthropos, 27, 543-619.

Prehistoric research in Indonesia. Ann. Bibl.

Indian Arch., 9, 26-38.

Prehistoric Research in the Netherlands Indies.

Science and scientists in the Netherlands Indies, 129-167.

Research on Southeast Asia: Problems and Suggestions. American Anthropologist, April, $149-175$.

Een neolithische boomschorsklopper uit Borneo. TBG, 75, 468-470.

De Praehistorie: Gesch. van Nederl. Indië. Catalogus der Praehistorische Verzameling. Batavia.

The outrigger canoes of Indonesia. Madras.

Outrigger devices: distribution and origin. Journ. of the Polynesian Society, 52, 1-100. Bark-Cloth in Indonesia. Journ. of the Polynesian Society, 43, 229-243.

Taalkundige gegevens ter bepaling van het stamland der Maleisch-Polynesische volken. Versl. en Med. Kon. Ned. Akad. van Wetensch. Amsterdam, 6, 270-287.

On the classification of some stone implements from Java and New Guinea. Abstracts Eighth Pac. Science Congr. Manilla, 531.

De praehistorische archaeologie van Java en Sumatra. Mensch en Maatschappij, 2, 378-379. Geklopte boomschors als kleedingstof op Midden Celebes en hare geographische verspreiding in 
1938:

Leach, E. R.

1938:

Leemans, C.

1852:

Lévy, Paul

1948:

Limburg Brouwer,

J. J. v.

1872:

Linehan, $\mathbf{N}$.

1928:

Maas, A.

1914:

Linn, Huisiang

1940:

Maglioni, R.

1938:

1940:

Mansuy, $\mathrm{H}$.

et Colani, M.

1925:

Mansuy, $\mathrm{H}$.

et Fromaget, L.

1924:

Menghin, $\mathrm{O}$.

1928:

Meyer, A. B. und Richter, $\mathrm{O}$.

1902/03:

Modigliani, E.

1894:

Munro, Neil G.

1914:

Naerssen, F. H. v. 1946:

Noone, H. D.

1939:

1941:
Indonesië. IAFE, 14, 139-191.

De West Toradjas op Midden Celebes. 5 vol. Amsterdam.

Stone implements from Botel Tobago Island. Man, 38, 161-163.

Over steenen wiggen op Java en eenige andere steenen voorwerpen op Borneo gevonden. Tijdschr. voor de Wis- en Natuurk. Wetensch., 5, $106-118$.

Recherches préhistoriques dans la Région de Mlu Prei. Hanoi.

Steenen beitels in 't Museum van 't Bataviaasch Gen. TBG, 18, 67-88.

Some discoveries on the Tembeling. Journ. Mal. Branch RAS, 6, 66-77.

Ein Steinbeil aus Kerintji. Zeitschr. f. Ethn., $46,81-86$.

A neolithic site in Wuping, Fukien. Proc. 3rd Congr. of Prehistorians of the Far East. Singapore, 133-141.

Archaeological finds in Hoifung. Hong Kong Naturalist, 7, 208-244.

Some aspects of South China Archaeological finds. Proc. 3rd Congr. of Prehistorians of the Far East. Singapore, 209-229.

Contribution à l'étude de la Préhistoire de l'Indo Chine. Mém. Serv. Géol. Indo Chine, 13.

Stations néolithiques de Hong-Rao et de KheTong, Annam. Bull. Serv. Géol. Indo Chine, 13.

Zur Steinzeit Ostasiens. Festschr. P. W. Schmidt, Wien. 908-942.

Steinzeit in Celebes. Miszellen Abh. und Ber. Kön. Zool. und Anthr. Ethn. Mus. Dresden, $72-91$.

L'isola delle donne. Viaggio, Engano. Milano.

Prehistoric Japan. Yokohama.

De oudste cultuurstromen. In: Wat Indië ontving en schonk. Amsterdam, 7-55.

Report on a new neolithic site in Ulu Kelantan. Journ. Fed. Malay St. Mus. 15, 4, 170-174.

A proposed classification of Malayan polished stone implements. Journ. Fed. Malay St. Mus., 15,4 . 
Patte, E.

1923:

1924:

Pleyte, G. M.

1887:

Rivet, P.

1932:

Rumphius, G. E.

1705:

Saurin, E.

1938:

1952:

Shellshear, C. M. 1932.

Skinner, H. D. 1940:

Speiser, F.

1938:

Stein Callenfels,

P. V. van

1926:

1930:

1932a:

1932b:

1934:

1940:

1950:

1951:
Note sur la préhistorique Indochinois. Bull.

Serv. Géol. Indo Chine, 12, 1.

Le kjökkenmödding néolithique du Bau-Trou près Dong-Hoi. BEFEO, 24, 521-536.

De praehistorische steenen wapenen en werktuigen uit den Oost Indischen Archipel, beschouwd uit een archaeologisch en ethnologisch oogpunt. Bijdr. TLV, 36, 586-604.

Les Océniens. Praehistorica Asiae orientalis. $35-46$.

D'Amboinsche Rariteitenkamer. Amsterdam.

Henri Mansuy (1857-1937). Proc. 3rd Congr. of Praehistorians of the Far East, Singapore, 313-316.

Station néolithique avec outillage en silex à Nhommalat, Laos. BEFEO, 46, 297-303.

A Contribution to the Prehistory of Hongkong and the New Territories. Praehistorica Asiae orientalis, $63-76$.

Maori adzes, axes, chisels and gouges from the Muruhiku regions, New Zealand. Proc. 3rd Congr. of Prehistorians of the Far East, Singapore. 142-172.

Melanesian and Indonesian. Zeitsch. f. Ethn., $6,463-480$.

Bijdrage tot de Chronologie van het Neolithicum in Z.O. Azië. OV, 174-180.

Problems of the stone-age in the Far East. Proc. of the Fourth Pac. Science Congr. Java, 1929, 3, 375-378.

Die Aufgaben der japanischen Prähistorie im Rahmen der internationalen Forschung. Zeitschr. f. Prähistorie, Shizengaku Zassi, 4, 119-136.

Some early migrations in the Far East. Man, $32,283-84$.

Korte Gids voor de Praehistorische Verzameling. The round axe in the Archipelago. Proc. 3rd Congr. of Prehistorians of the Far East. Singapore, $131-132$.

Voorlopig verslag van Dr P. V. van Stein Callenfels over zijn Galoempang onderzoek. O.V., 1949, 49-53.

Prehistoric sites on the Karama River, West Toradjaland, Central Celebes. Journ. of East Asiatic Studies. Manilla, 1, 82-97. 
Stresemann, E. 1939:

Swaving, C. 1850:

Torri, Ryozo 1932:

Tweedie, M. W. F. 1942:

1949:

1953:

1955:

Vrolik, W.

1850:

Williams-Hunt,

P. D. R.

1951:

Winstedt, R. O.

1932:

Wray, E.

1903:
Die Vögel von Celebes. Journ. f. Ornithologie, $87,312-425$.

Berigt en afteekening van eenige steenen wiggen en wapenen. Natuurk. Tijdschr. voor Ned. Indië, 1, 81-85.

Restes néolithiques de la Manchouria méridionale et de la Mongolie Orientale. Praehistorica Asiae orientalis.

Prehistory in Malaya. Journ. of the Royal Asiat. Soc., 1-13.

The Malayan Neolithic. The Polynesian Society. Wellington, New Zealand, 58, 19-35.

The Stone Age in Malaya. Journ. Mal. Branch RAS, 26, 2. Monograph 1, 1-90.

Prehistoric Malaya. Background to Malaya Series, 6.

Berigt over zes steenen wiggen op Java gevonden. Tijdschr. voor de Wis- en Natuurk. Wetensch. 3, 99-102.

Recent archaeological discoveries in Malaya. Journ. Mal. Branch RAS, 24, 1, 186-191.

The prehistory of Malaya. Journ. Mal. Branch RAS, 15, 1, 181-190.

The Malayan pottery of Perak. Journ. Anthrop. Inst. 33, 24. 


\section{AN ATTEMPTED CHRONOLOGY OF THE STONE AGE OF INDONESIA}

THE PLEISTOCENE PERIOD

\section{Deposits}

Lower Pleistocene I

Putjangan beds a:

tuffs, sandstone

Putjangan beds $\mathbf{b}$ : black clay tuffs

Middle Pleistocene

Kabuh beds a: volcanic lahar

Trinil bone bed

Trinil plant bed

Kabuh beds b: volcanic lahar erosion and uplift

Hominids

Fauna

Archaeology

Tji Djolang:

Merycopotamus

Archidiskodon pl.

Kali Glagah:

Mastodon bumiaj.

Cervus stehlini

Djetis:

Cervus zwaani

Leptobos

Stegodon trig.

modjokertensis

Pithecanthropus

erectus

Trinil:

Duboisia kroes.

Elephas namad.

Echinosorex

Pithecanthropus erectus

Homo soloensis

Upper Pleistocene

Notopuro beds

erosion and uplift

fluviatile aggradation

Tjabengeे terraces: erosion and uplift

Wadjak Lake terr. erosion, volcanism and earth movements
Homo wadjakensis

Wadjak:

Tapirus
PALAEOLITHIC

Patjitan Chopper Industry Choppers, chopping-tools, proto hand-axes; $5-6 \%$ hand-axes; flaketools

\section{Ngandong:}

Stegodon trig.

Sus terhaari

Tjabengè:

Archidiskodon cel.

Celebochoerus

Sangiran Flake Industry: short and stubby flake tools of yellow and red jasper and chert

Tjabengè Flake Industry: short and stubby flake tools of jasper and chert, incl. ogival points. 
THE HOLOCENE PERIOD

Deposits

Volcanism, uplift accompanied by tilting; deposition of the lower streamterraces

\author{
Hominids \\ Dolichoce- \\ phalic me- \\ galodonts
}

Mesocephalic megalodonts

Pygmoids

Early Indonesians?

Malayo-Polynesians?

Neo-Melanesians?

\author{
Fauna \\ Achin \\ Elephas max. \\ bear, deer, \\ Rhinoceros sond.

\section{Sampung:} \\ Elephas max. \\ Rhinoceros Sond. \\ Cervus eldi
}

Toalean:

Sus celebensis

Babyrousa

Anoa depr.

Phalanger ursinus

Phalanger celeb.

recent

domesticated dog and pig

recent

domesticated dog, pig and fowl

recent

domesticated dog, . and pig
Archaeology

MESOLITHIC

Bacson-Hoabinhian:

Sumatraliths, 'short'

axes, pestles and mor-

tars. Tools fashioned from

rhyolite and andesite;

kitchenmiddens, red ochre.

\section{Sampungan:}

spatulas, awls and daggers of bone and horn; stone pestles and mortars. Red ochre; flexed burial.

adornments: perforated shells and animal teeth.

\section{Toalean I:}

Flake-tools, crude blades, pedunculated tools.

Toalean II:

Microliths, blade-tools, composite stone tools of chalcedony, jasper and obsidian. Rock-paintings in striped line technique; negative hand-stencils. Human skeletal parts as mementoes; amulets of stone and mother-of-pearl.

\section{NEOLITHIC}

Quadrangular Adze Culture Quadrangular Adzes, Pick Adzes; armlets and beads of stone and shell. Pottery. Bark-cloth. Headhunting; dogs and pigs for food and sacrificial purposes.

Late Quadrangular Adze Culture

Quadrangular Adzes, stepped adzes, crude shouldered axes, stone rings; barkcloth.

Round Axe Culture

Round axes, coiled pottery.

Toalean $I I$ :

barbed, winged arrowheads. Muduk points, potsherds. 
H.R. van Heekeren - 978-90-04-28643-6 Downloaded from Brill.com๑4/26/2023 09:07:18AM via free access 
H.R. van Heekeren - 978-90-04-28643-6 Downloaded from Brill.com๑4/26/2023 09:07:18AM via free access 
H.R. van Heekeren - 978-90-04-28643-6 Downloaded from Brill.com๑4/26/2023 09:07:18AM via free access 
PLATES 

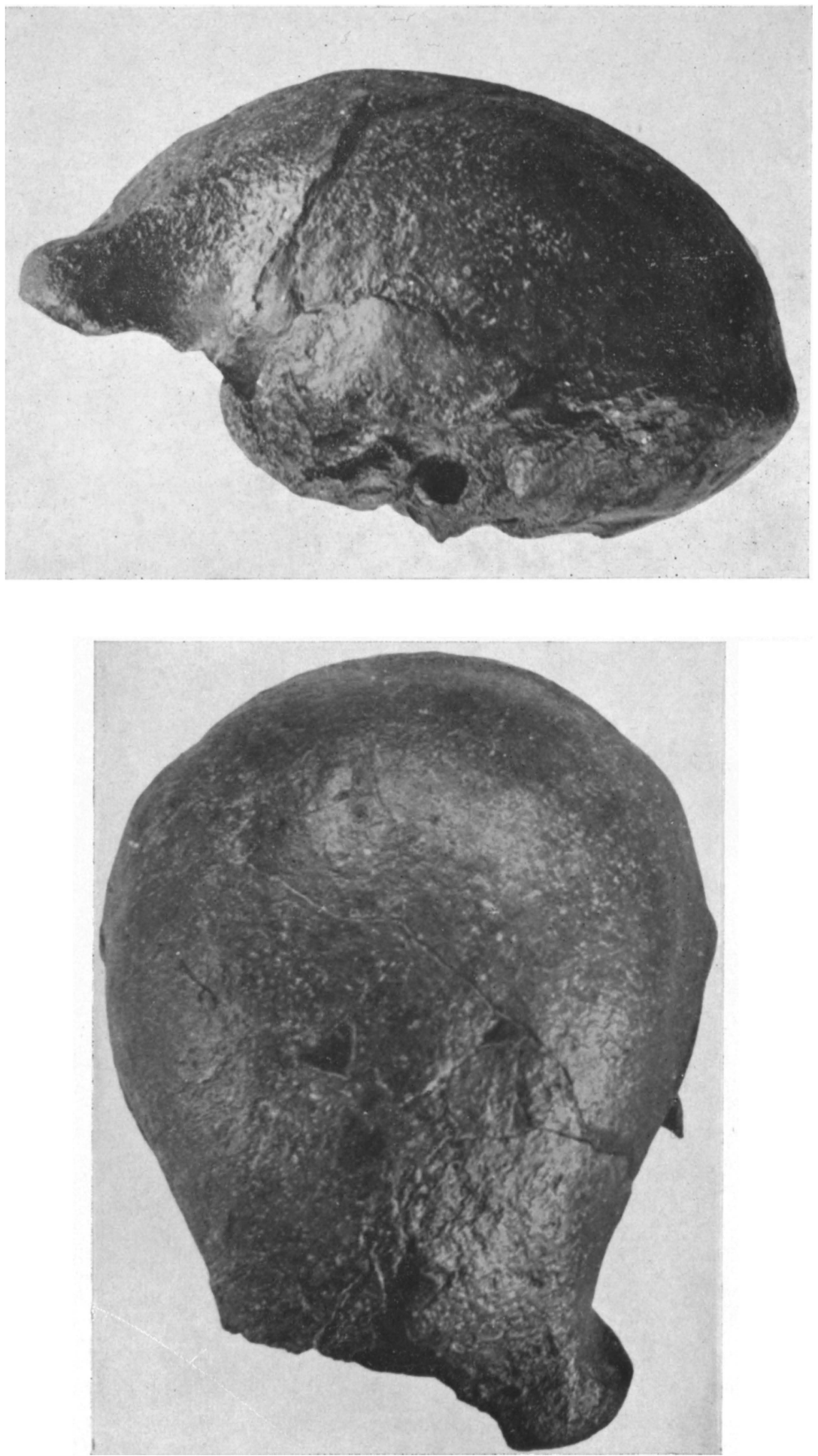

By courtesy of G. H, R. von Koenigswald.

Pl. 1A and 1B. Pithecanthropus II. Above, lateral view. Below, vertical view.

H.R. van Heekeren - 978-90-04-28643-6 Downloaded from Brill.com04/26/2023 09:07:18AM 

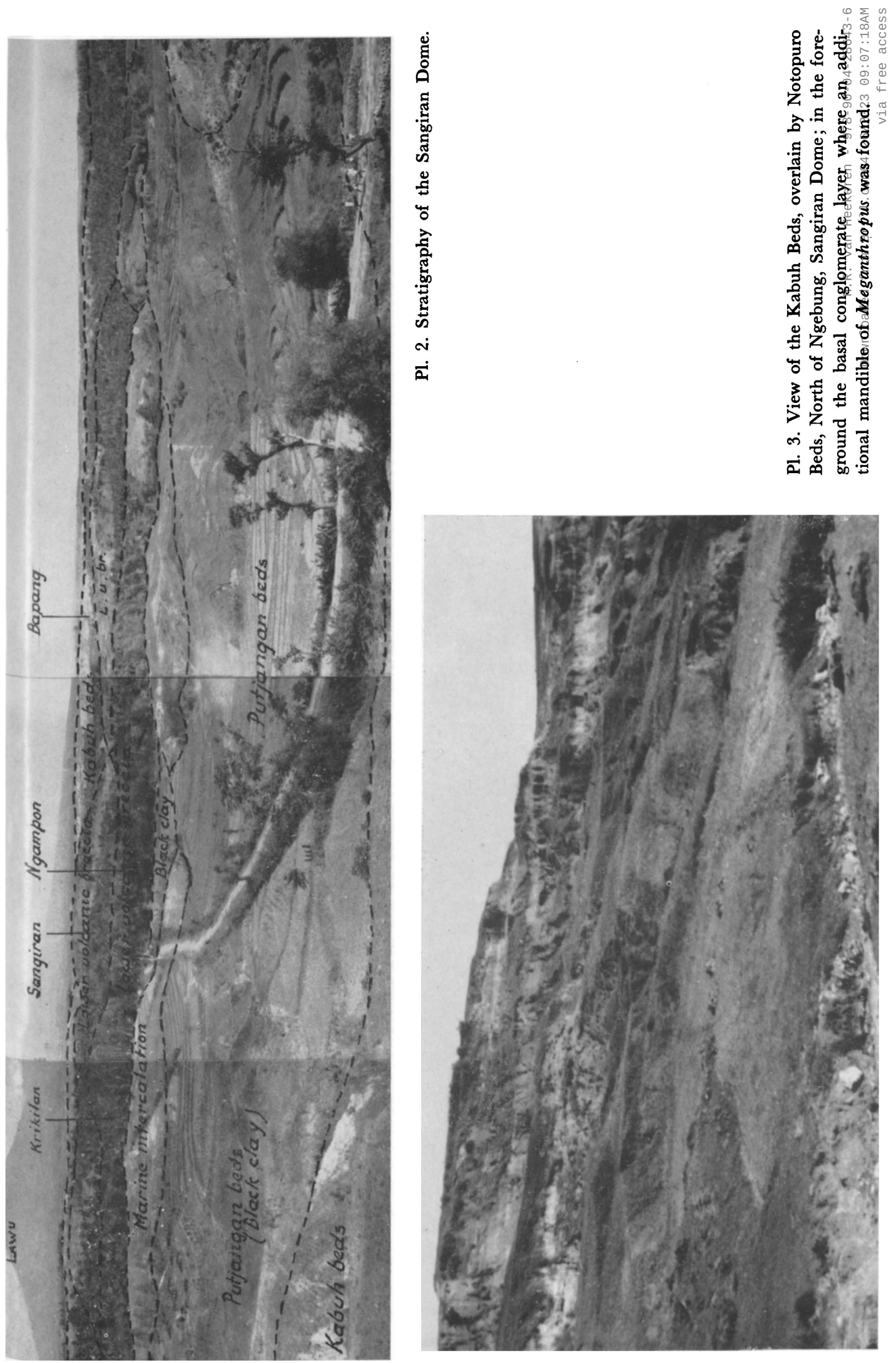


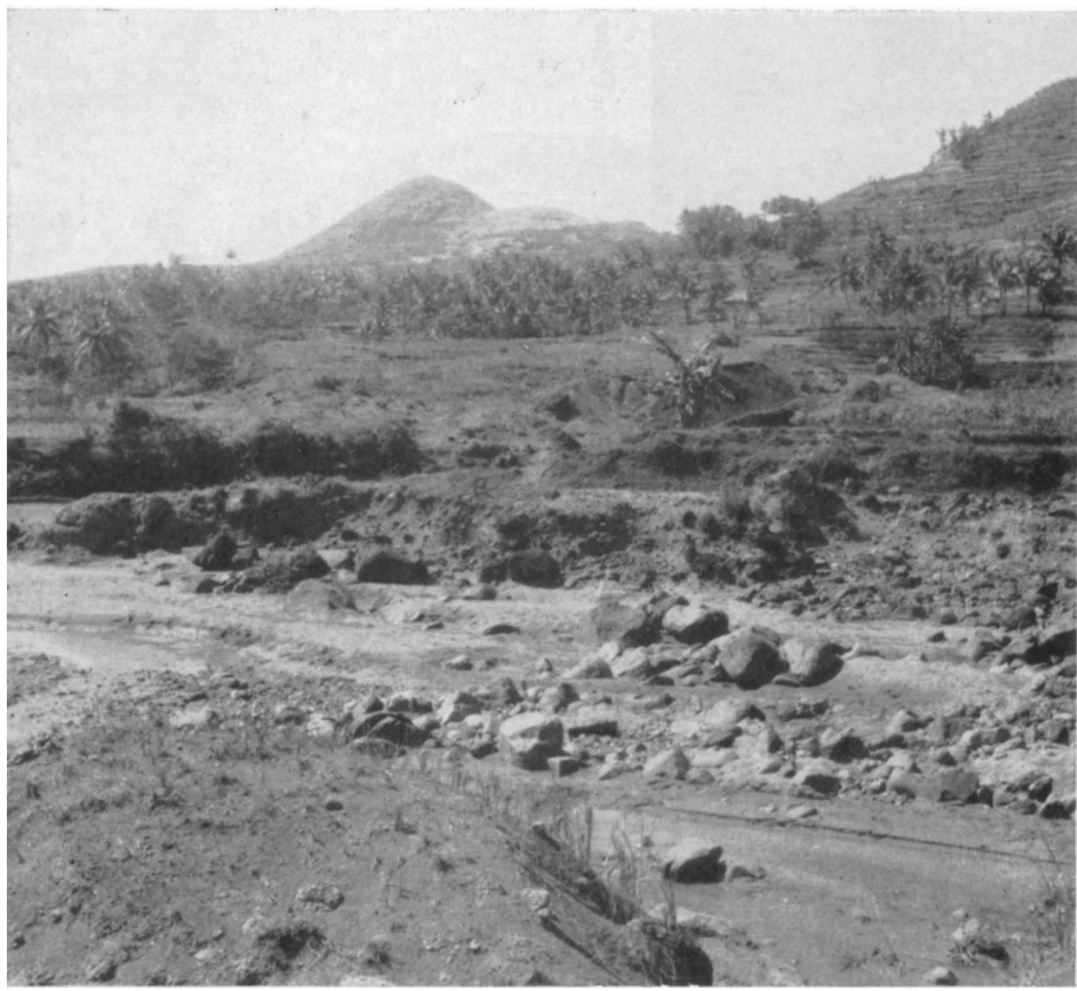

Pl. 4. Baksoka River: a bouldergravel $1 \frac{1}{2}$ metres above the level of the river, containing palaeoliths.

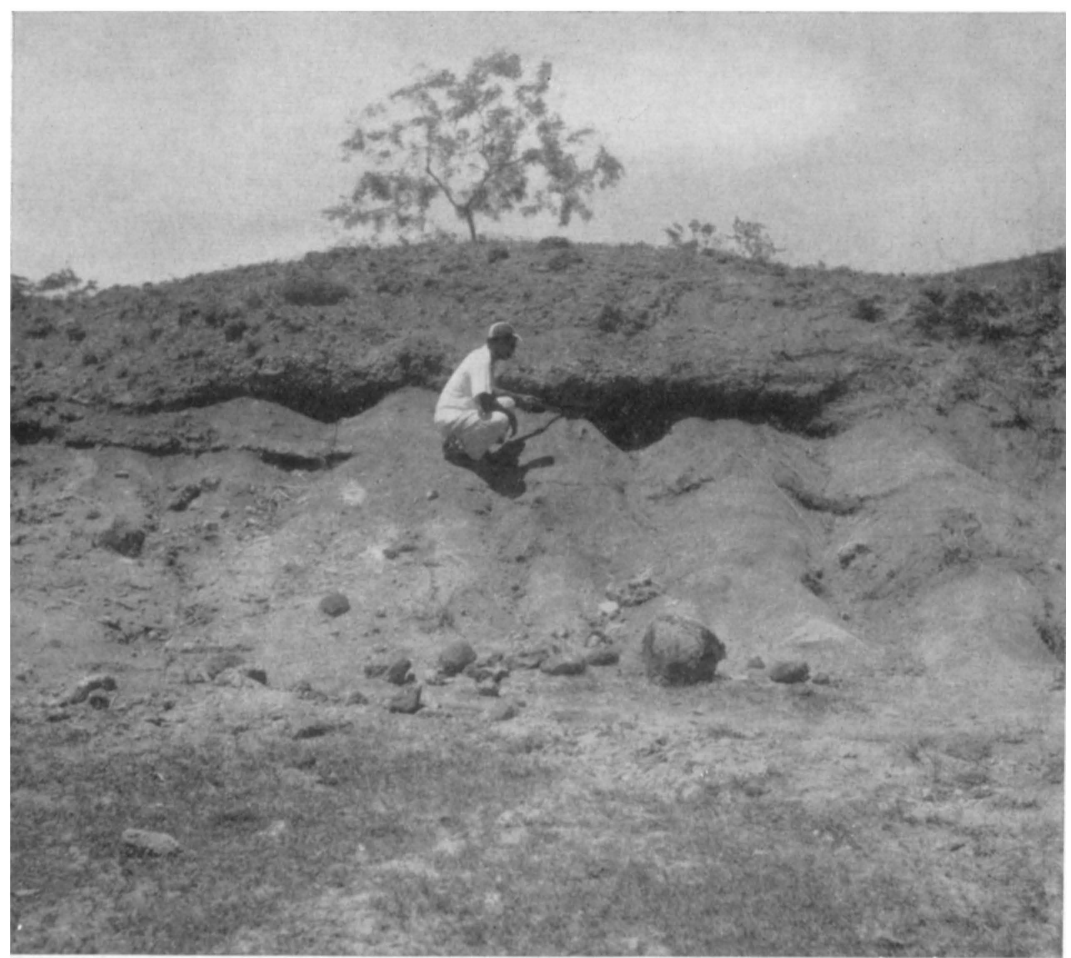

P1. 5. Implementiferous red-gravel 7 metres above stream-level resting on tuff $_{90-04-28643-6}$ Downloaded from Brill.come4/26/2023 09:07:18AM 

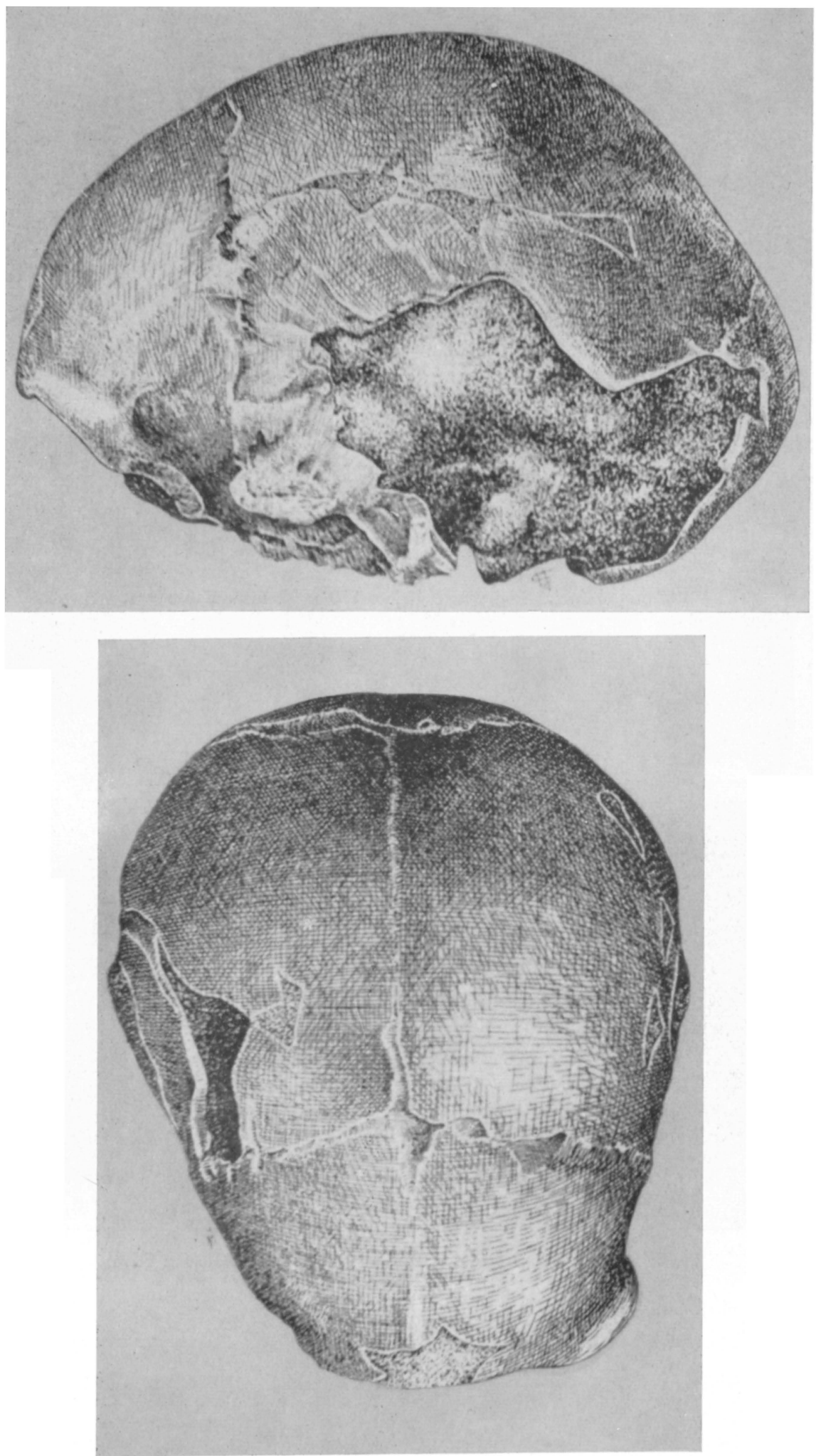

By courtesy of G. H.R. von Koenigswald.

Pl. 6A and 6B. Homo modjokertensis.

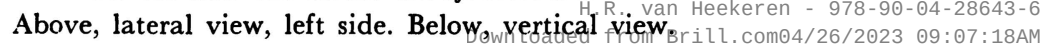




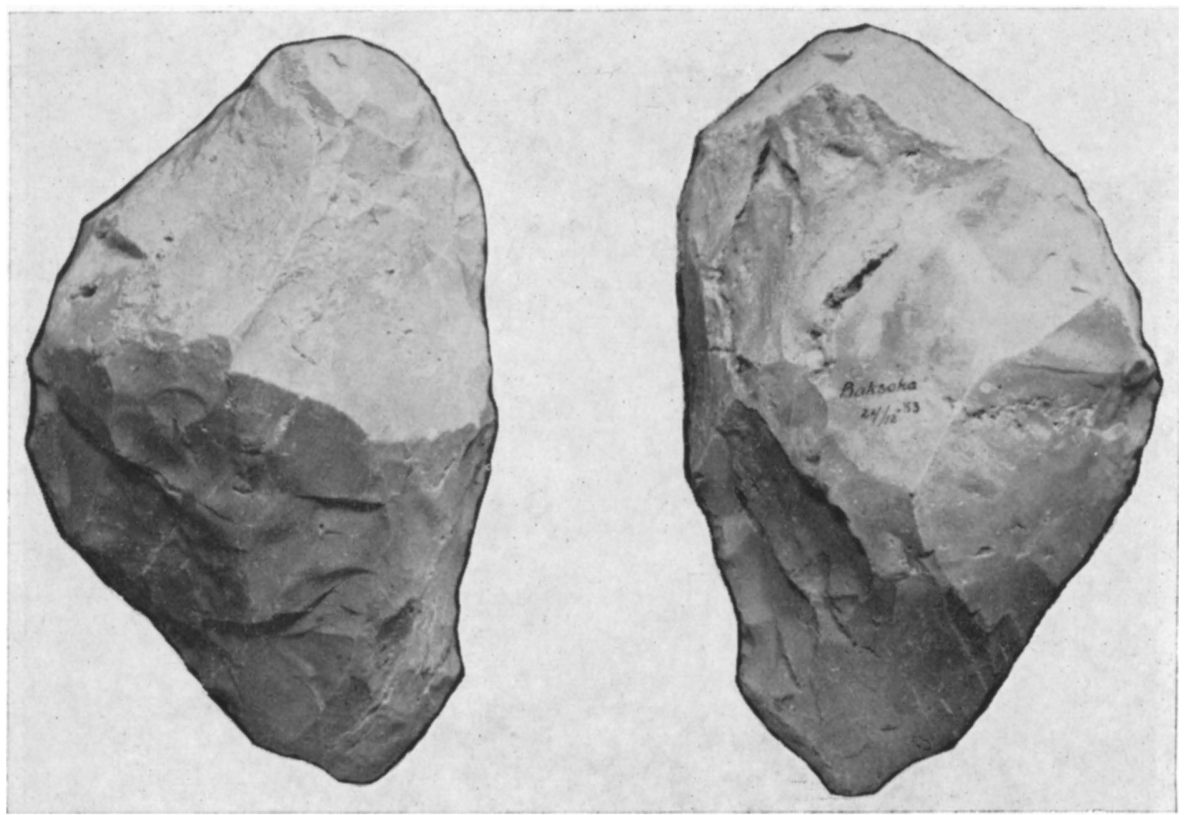

P1. 7. Long, bifacial Hand-Axe 189 × 118 × 72 mm. Baksoka River.

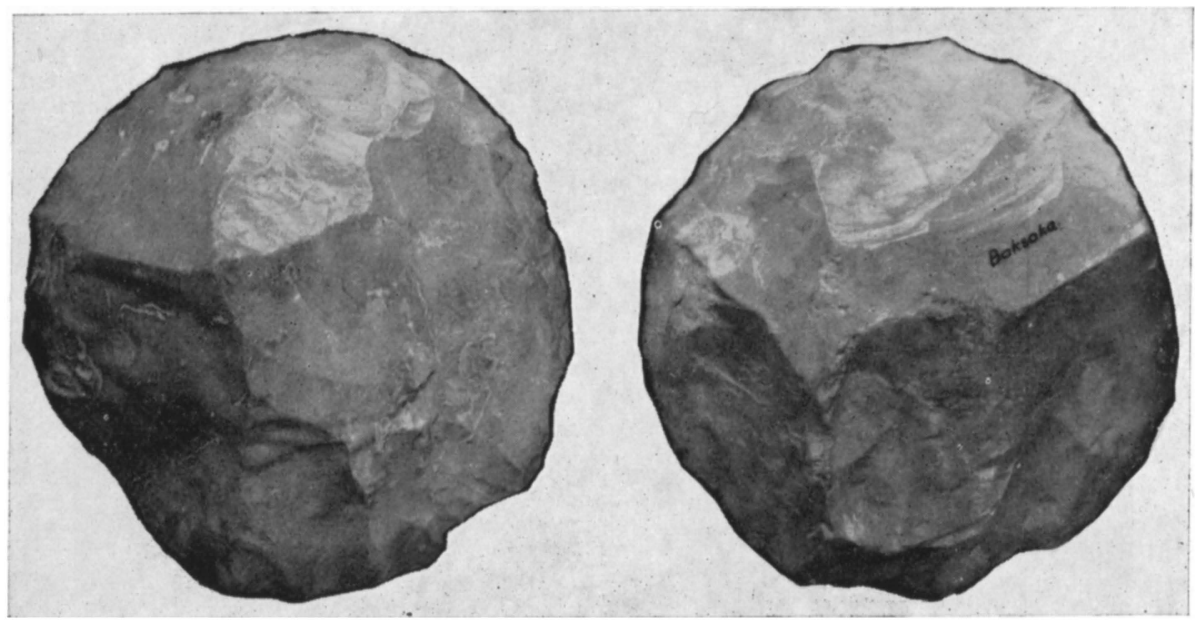

Pl. 8. Round, bifacial tool $120 \times 114 \times 65 \mathrm{~mm}$. Baksoka River. 


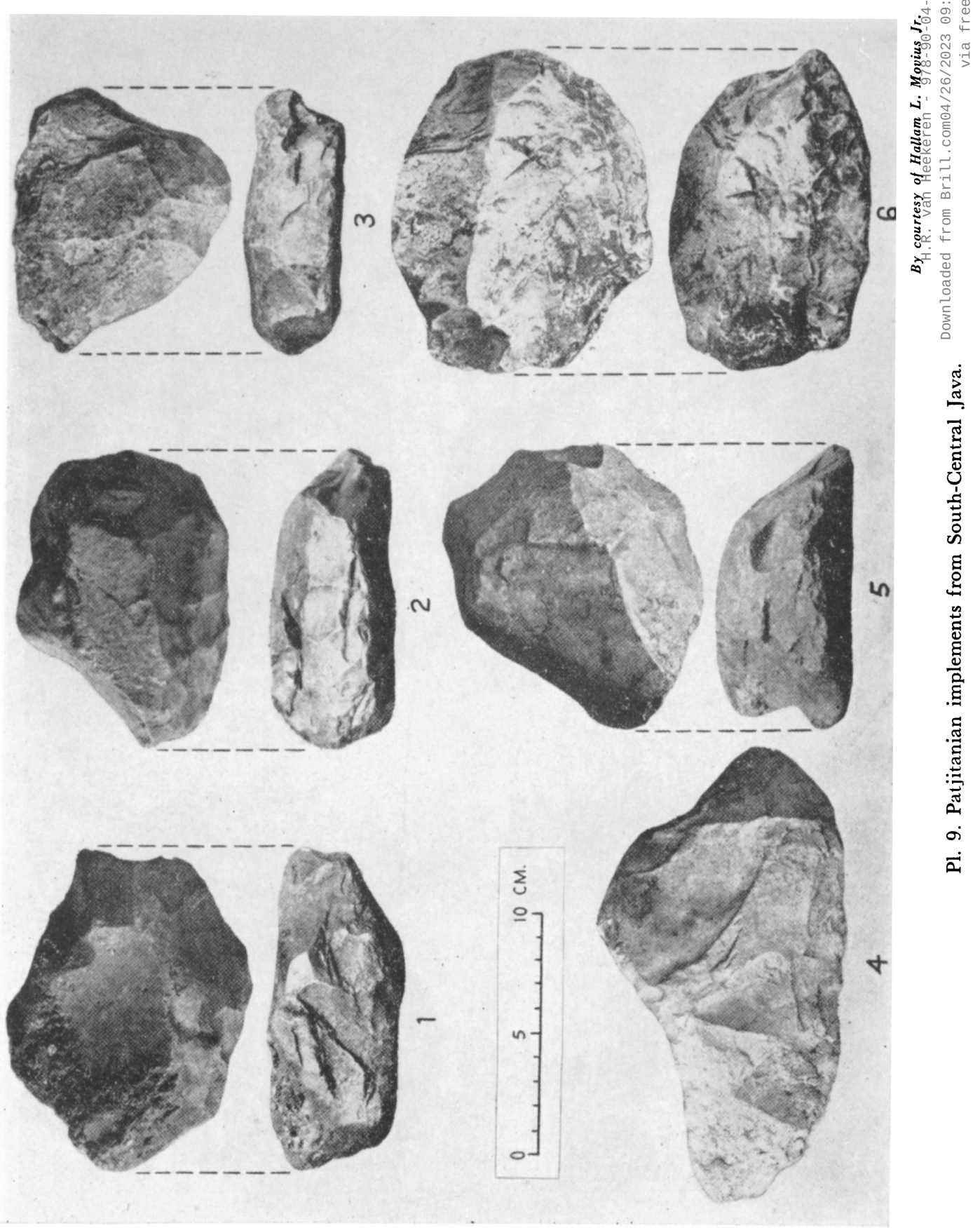




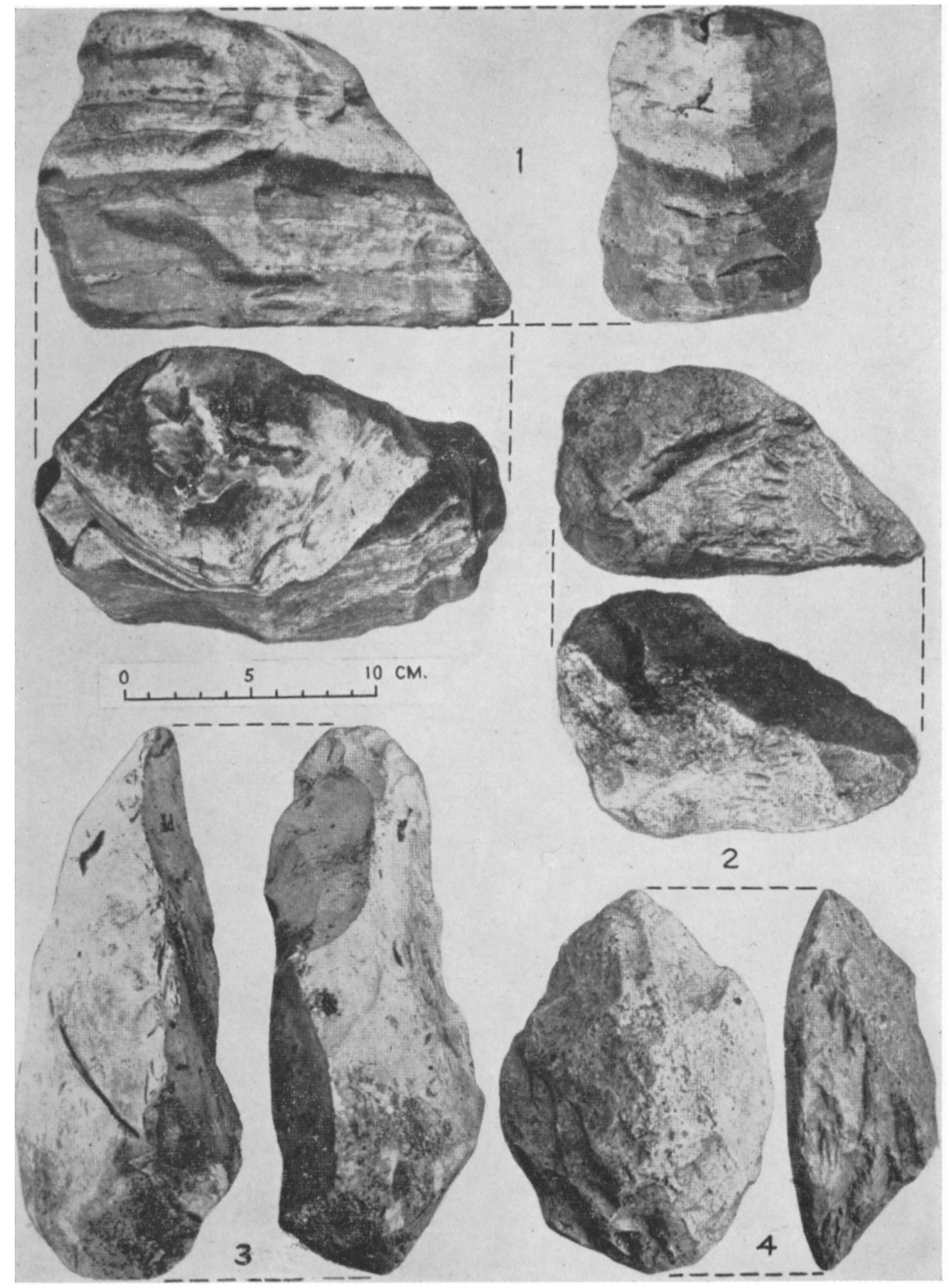

By courtesy of Hallam L. Movius Jr.

Pl. 10. Patjitanian implements from South-Central Java. 1-4 Proto Hand-Axes. 


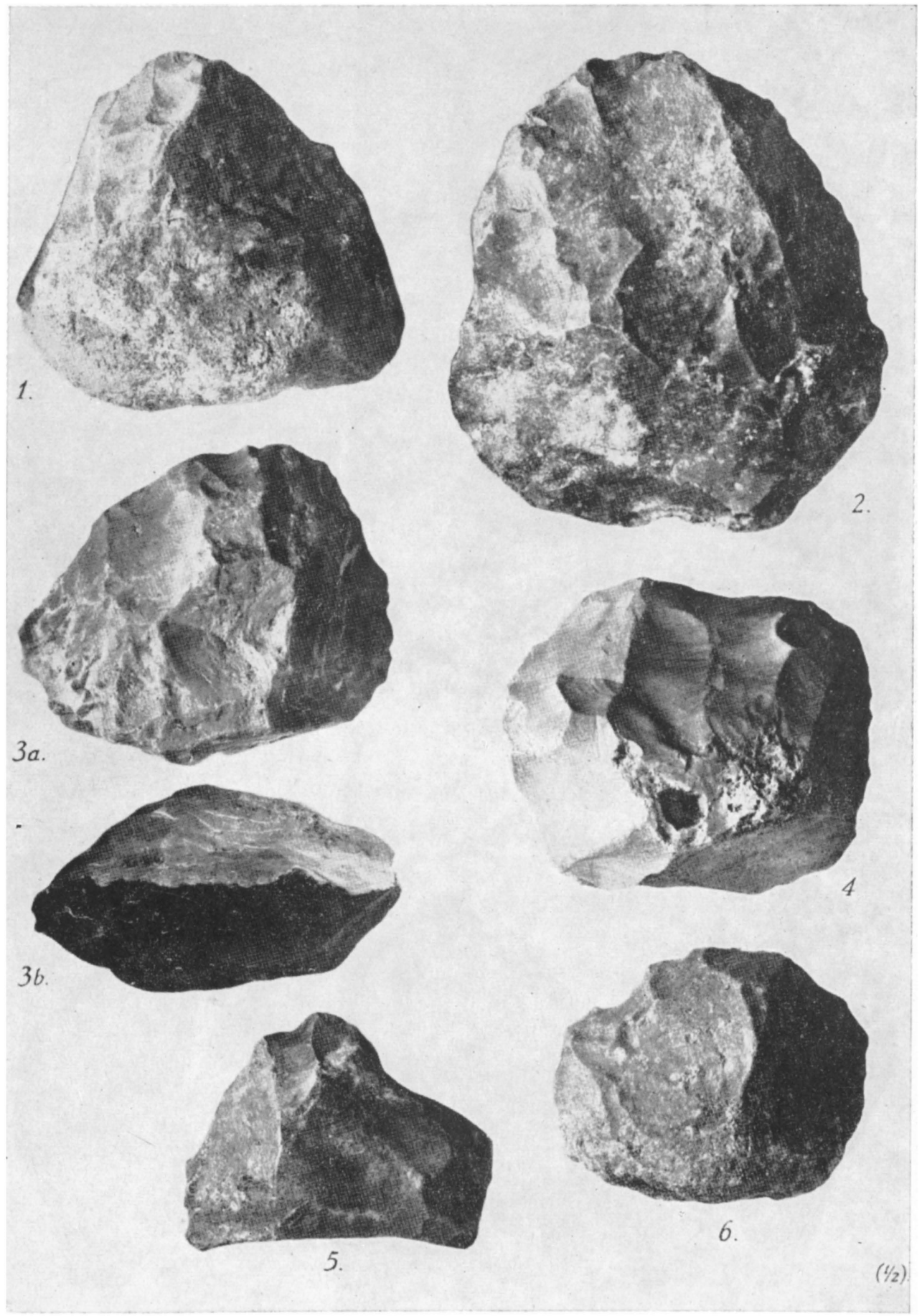

Pl. 11. Patjitanian implements South-Central Java. 1-2, 4-6 Choppers. 3 Chopping-tool. 


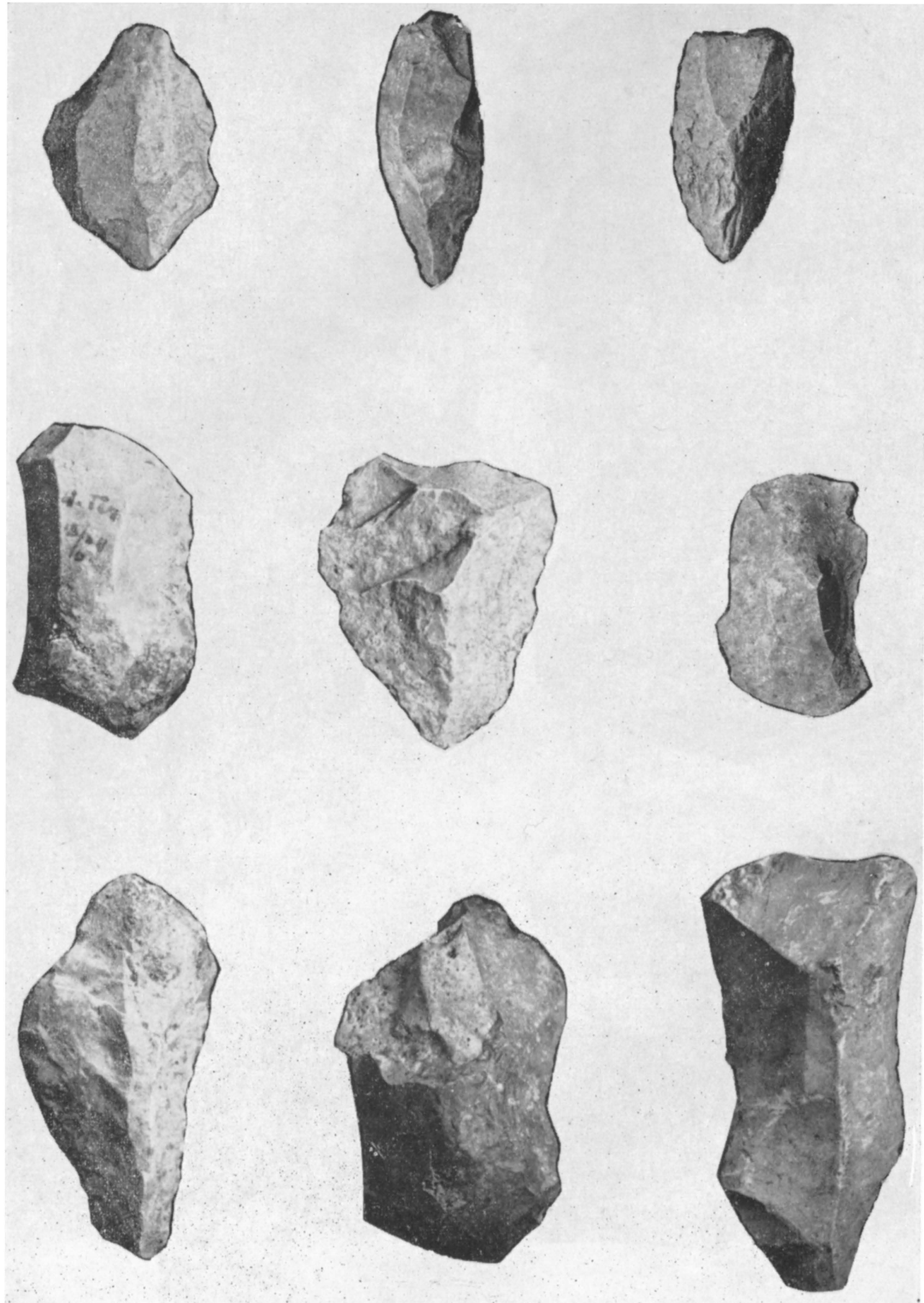

Pl. 12. Various types of Flake-tools. $15-20 \mathrm{~m}$. terrace Baksoka River. 


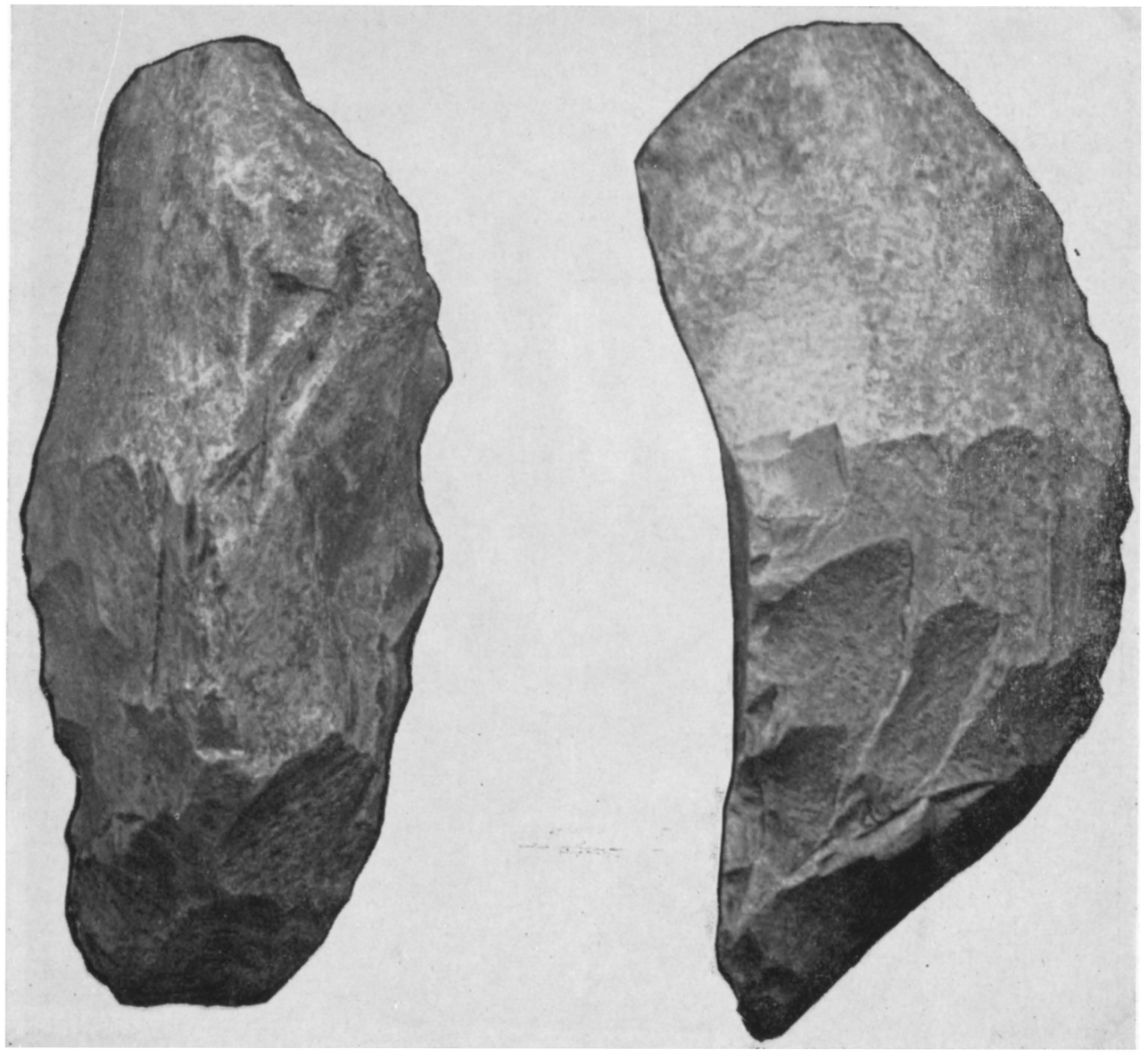

Pl. 13a. Keeled 'Flat-iron' Chopper 204 x 94 x $94 \mathrm{~mm}$. 15--20 m. terrace Baksoka River.

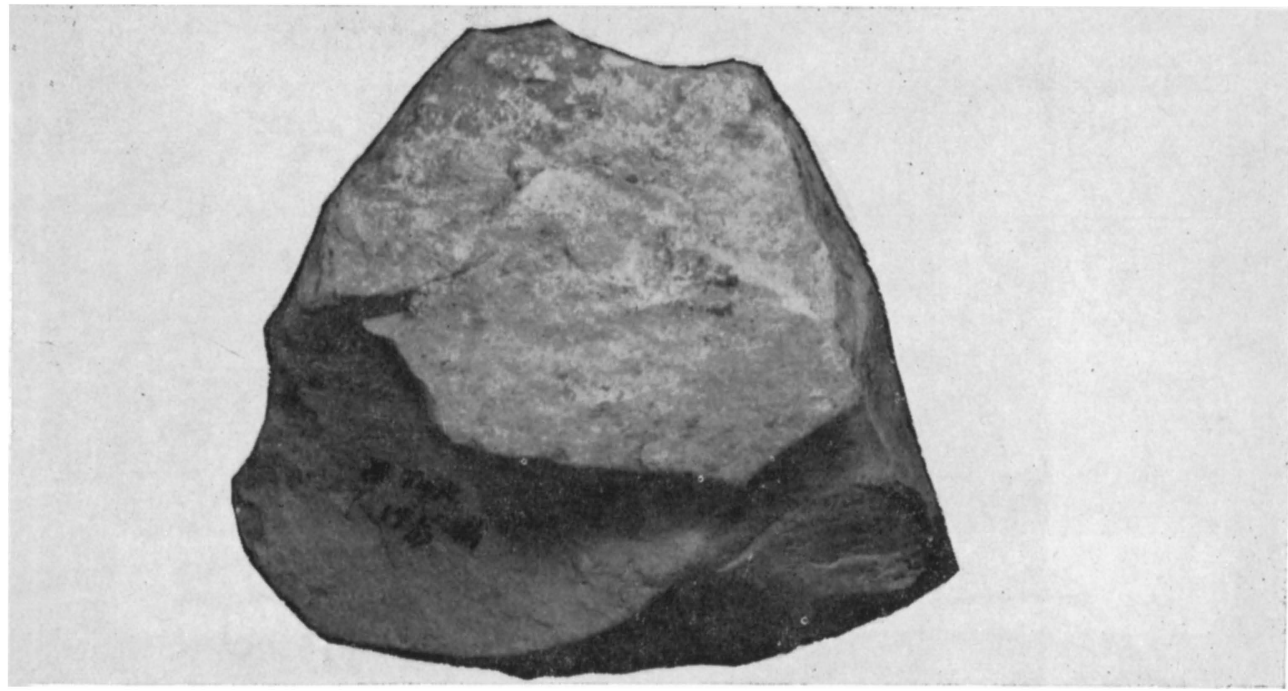

Pl. 13b. Gleaver on flake, $108 \times 125 \times 58 \mathrm{~mm} .15-20 \mathrm{~m}$. terrace Baksoka River. 


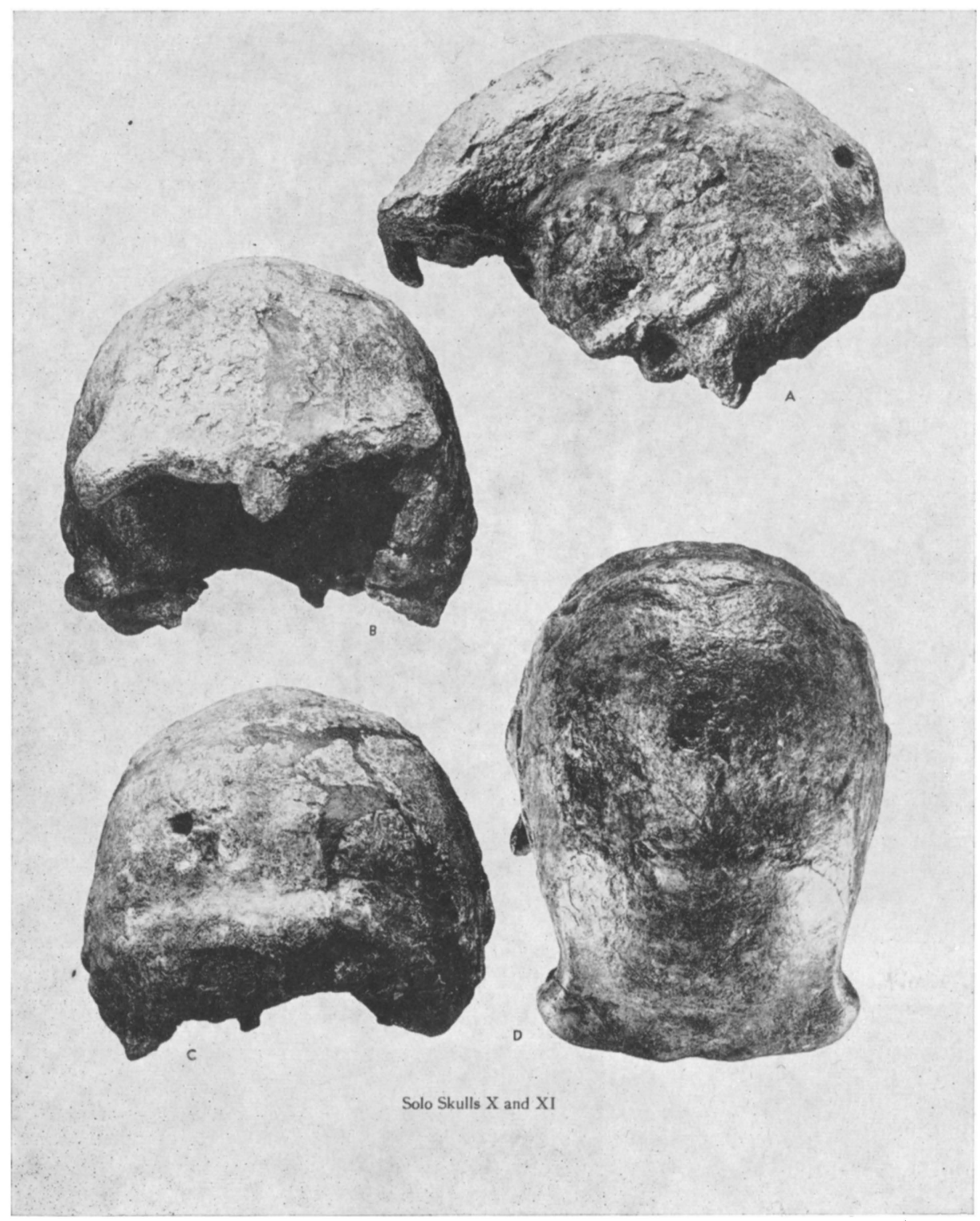

After $\boldsymbol{F}$. Weidenreich.

Pl. 14. Homo soloensis.

Skull X. A. lateral view, left side. B. frontal view.

Skull XI. C. occipital view. D. vertical view. 

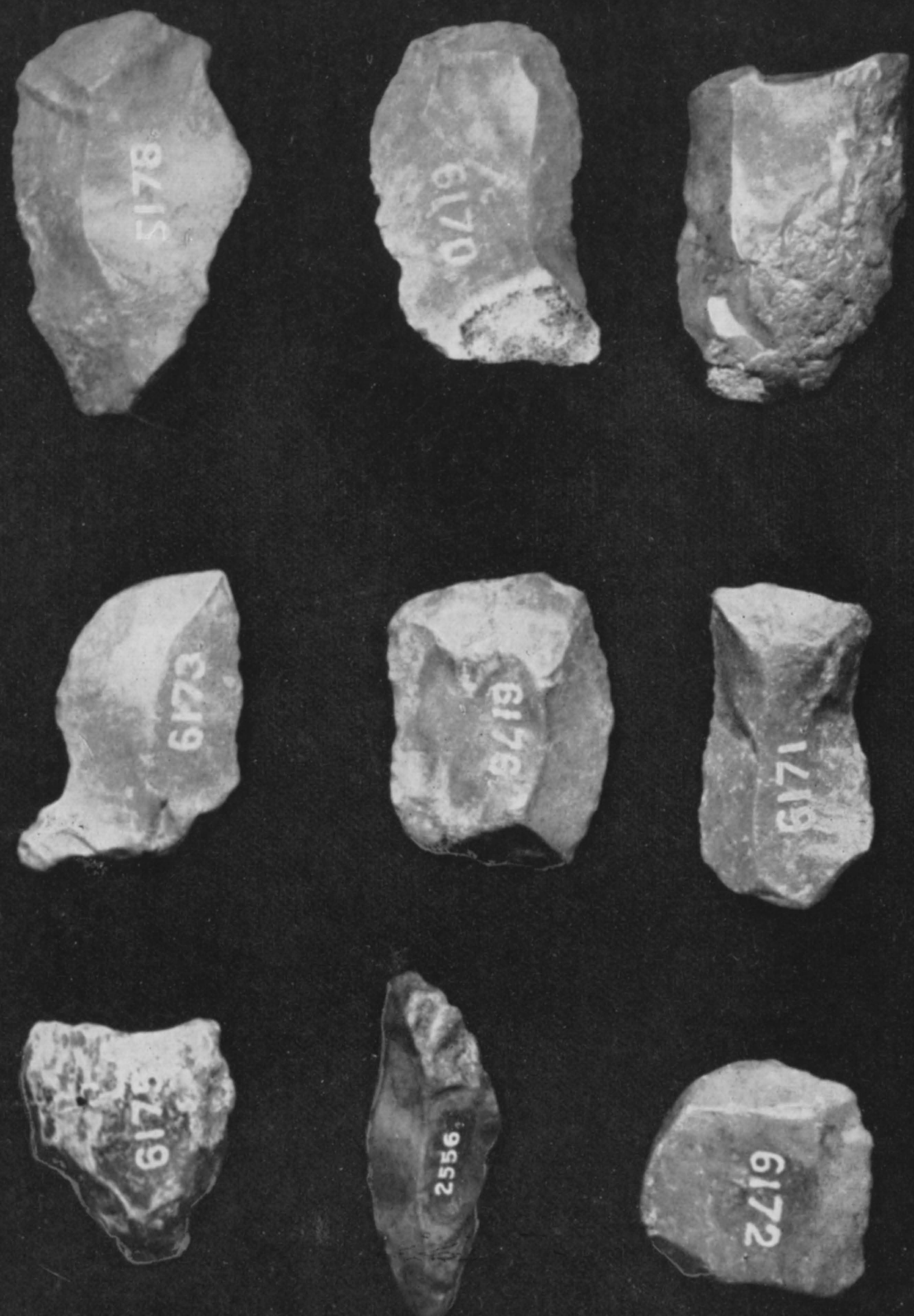

9

$10 \mathrm{~cm}$

Pl. 15. Upper Palacolithic Flake-tools. Sangiran. Java.

Downloaded from Brill. com๑4/26/2023 09:07:18AM 


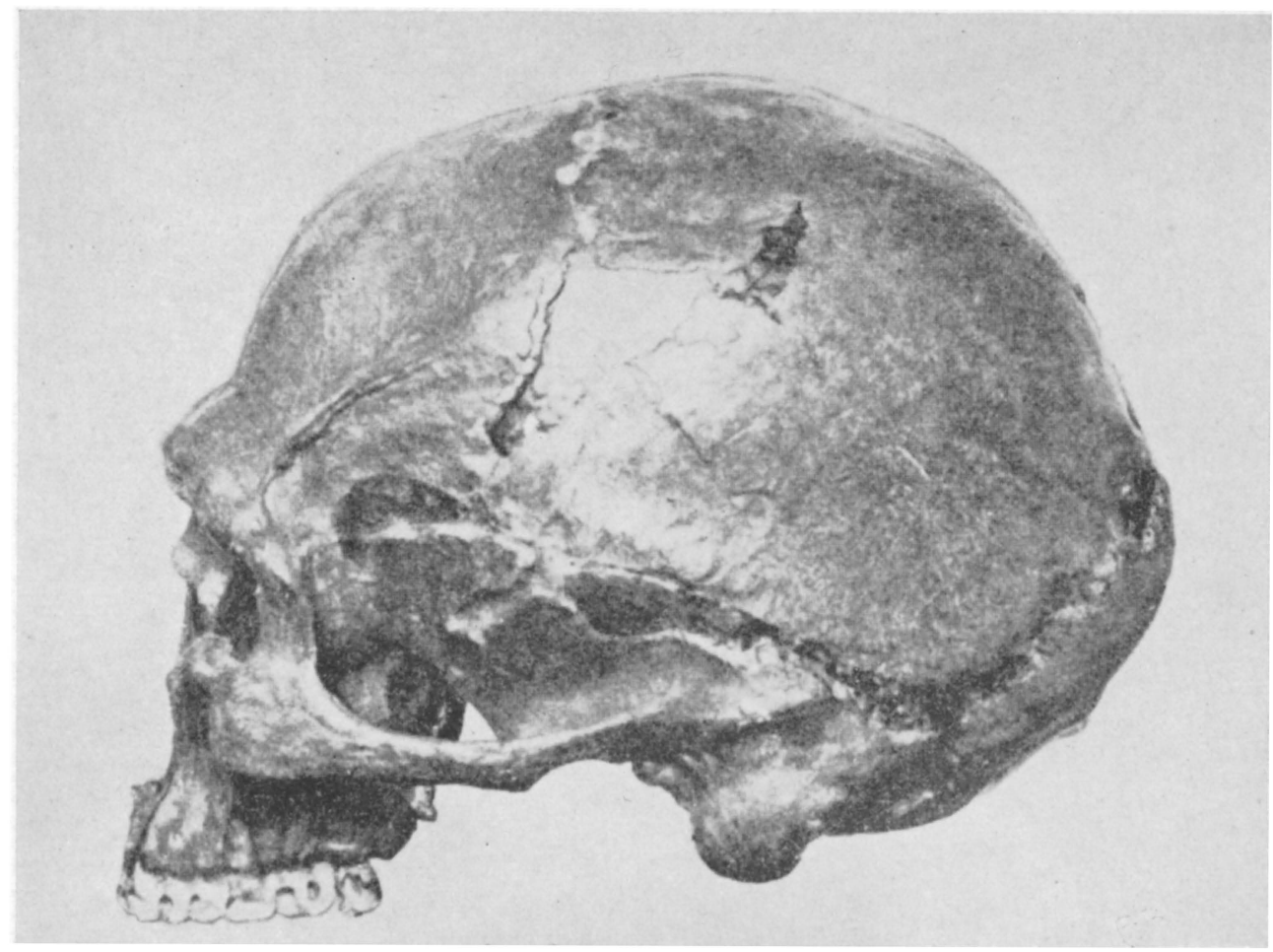

P1. 16. Skull of Homo wadjakensis, Java.

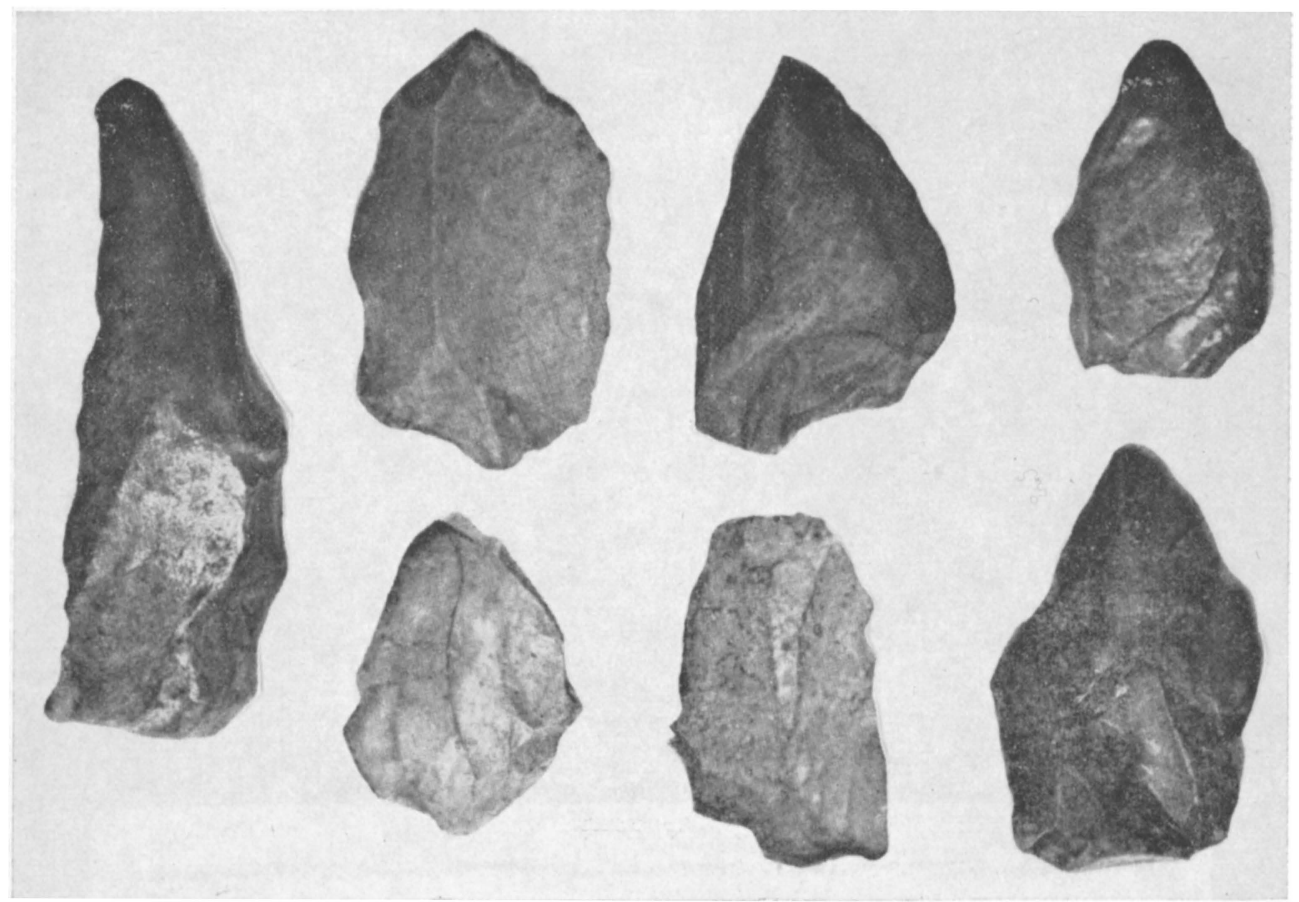

Pl. 17. Upper Palaeolithic Flake-tools. Tjabengè, South Celebes. 


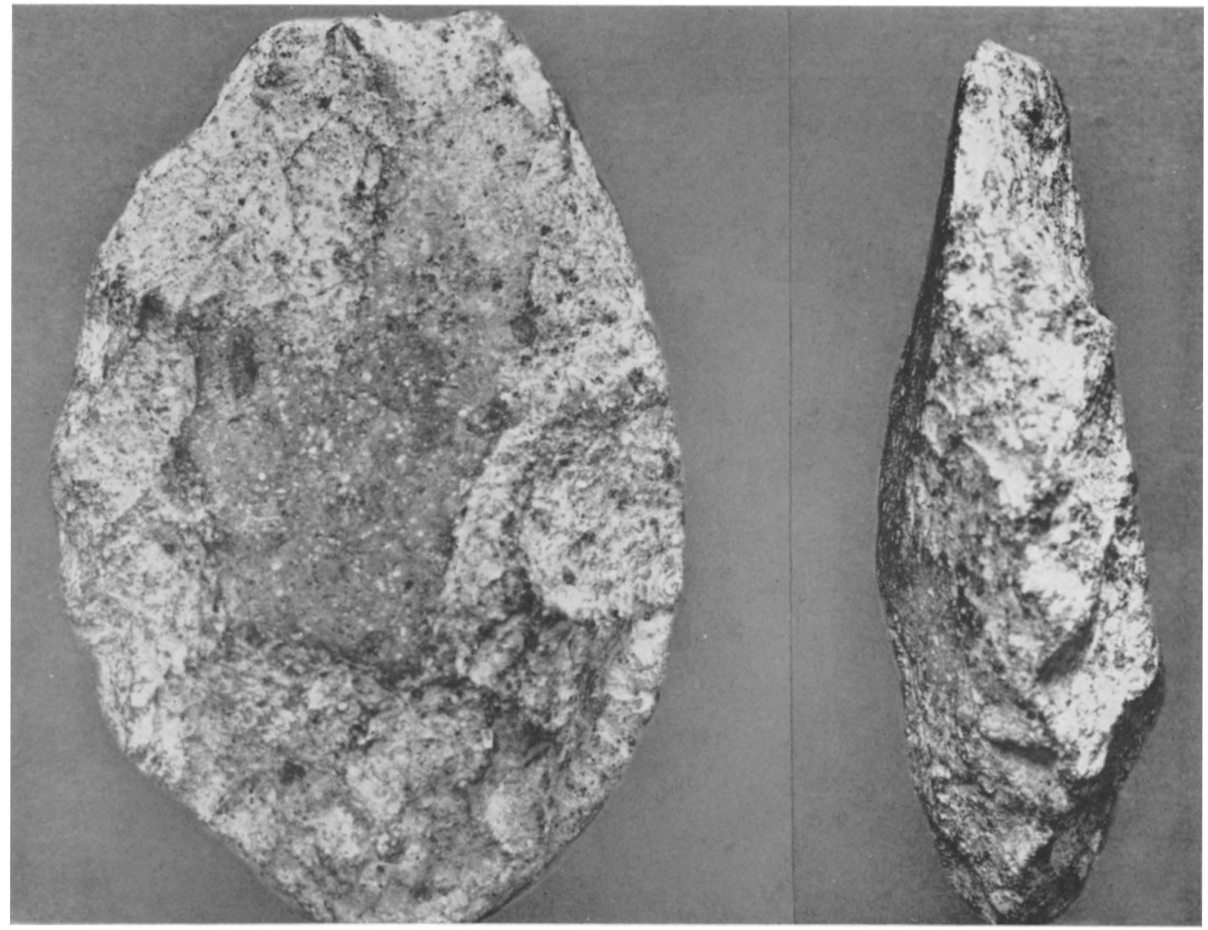

P1. 18. Bifacial Hand-Axe. East Coast of Sumatra.

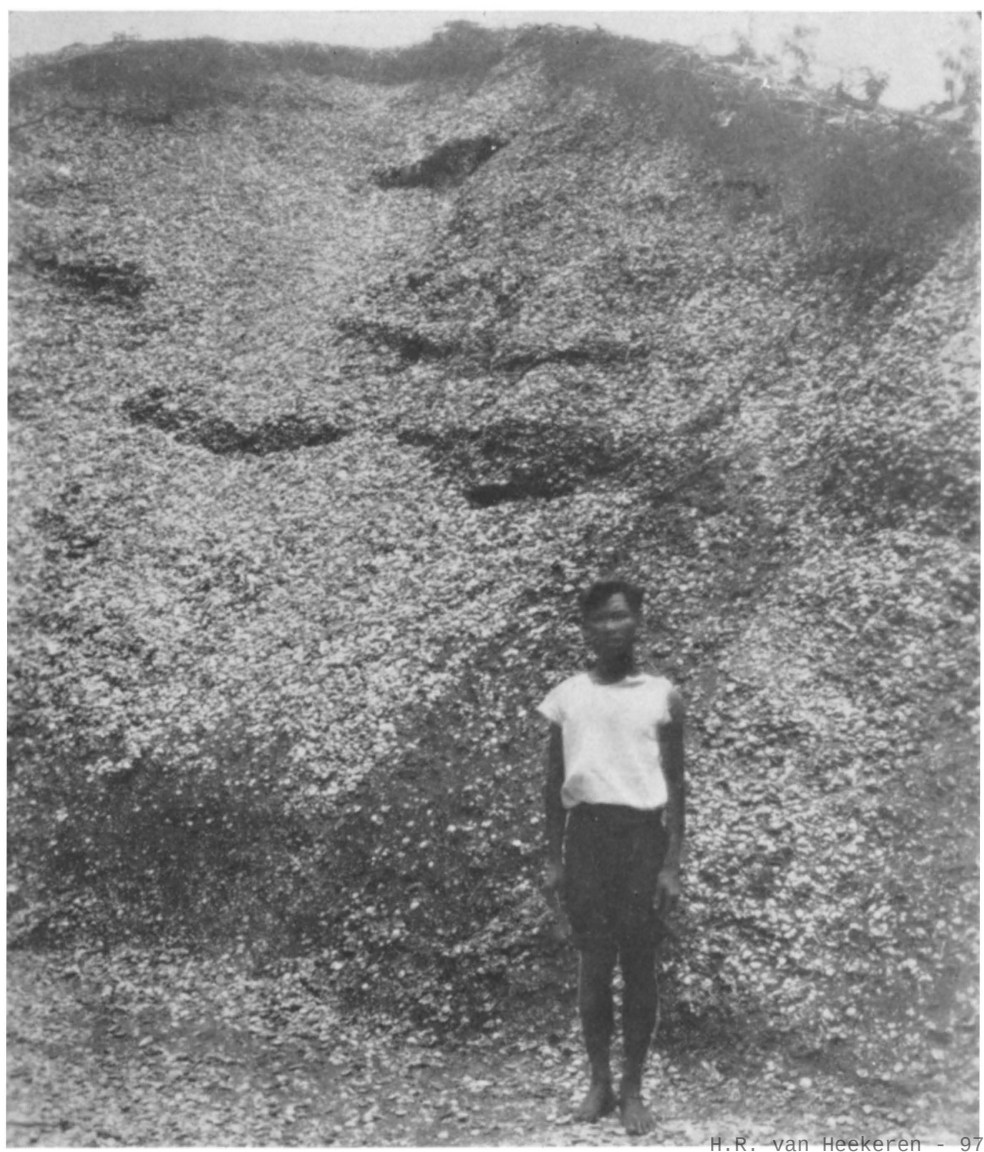

Pl. 19. Saentis Kitchenmidden. East ${ }^{\mathrm{D}}$ Coast of Sumatral.com04/26/2023 09:07:18AM 


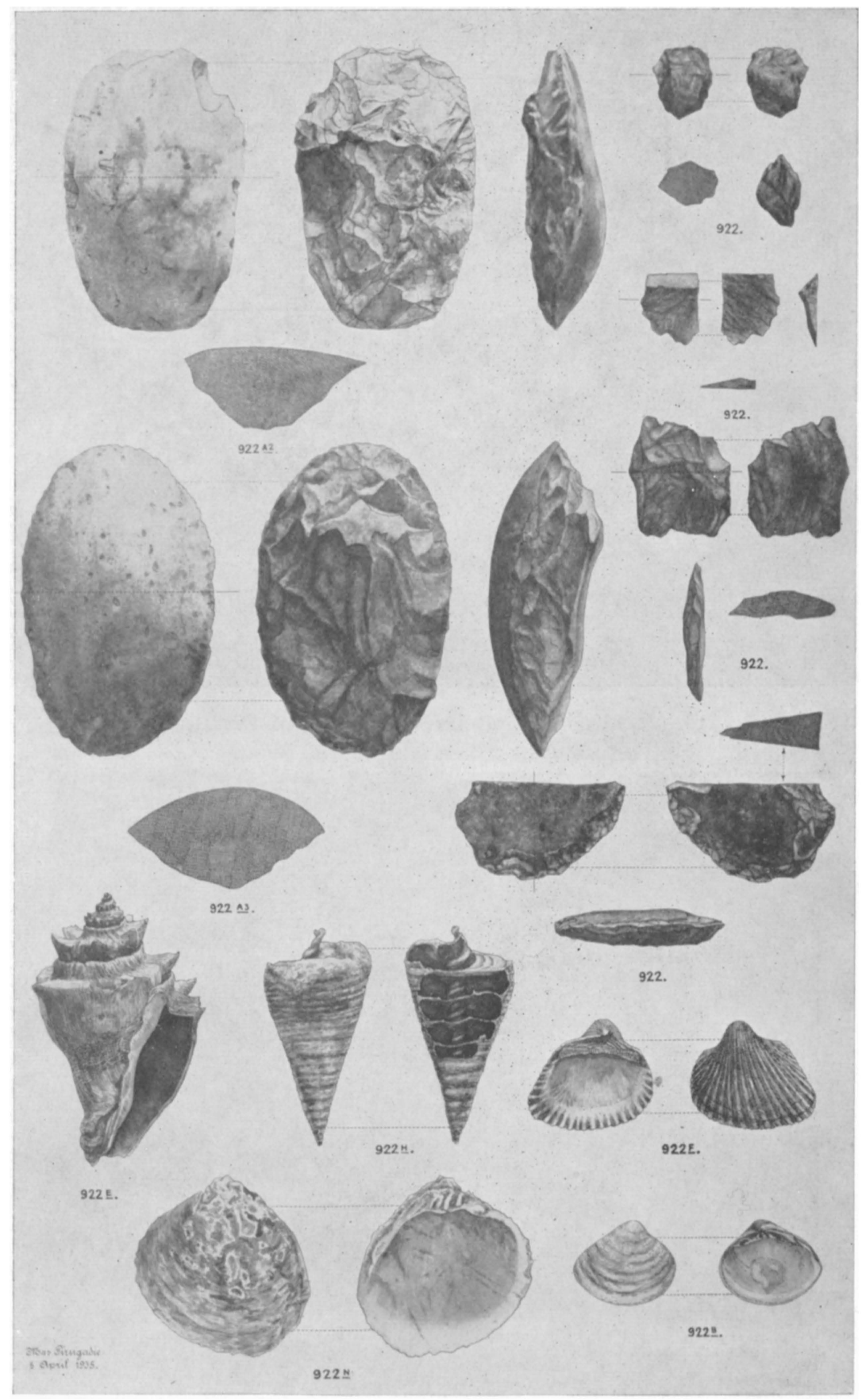

Pl. 20. Sumatraliths and shells. Saentis Shell Mound, Eastern Sumatra. 


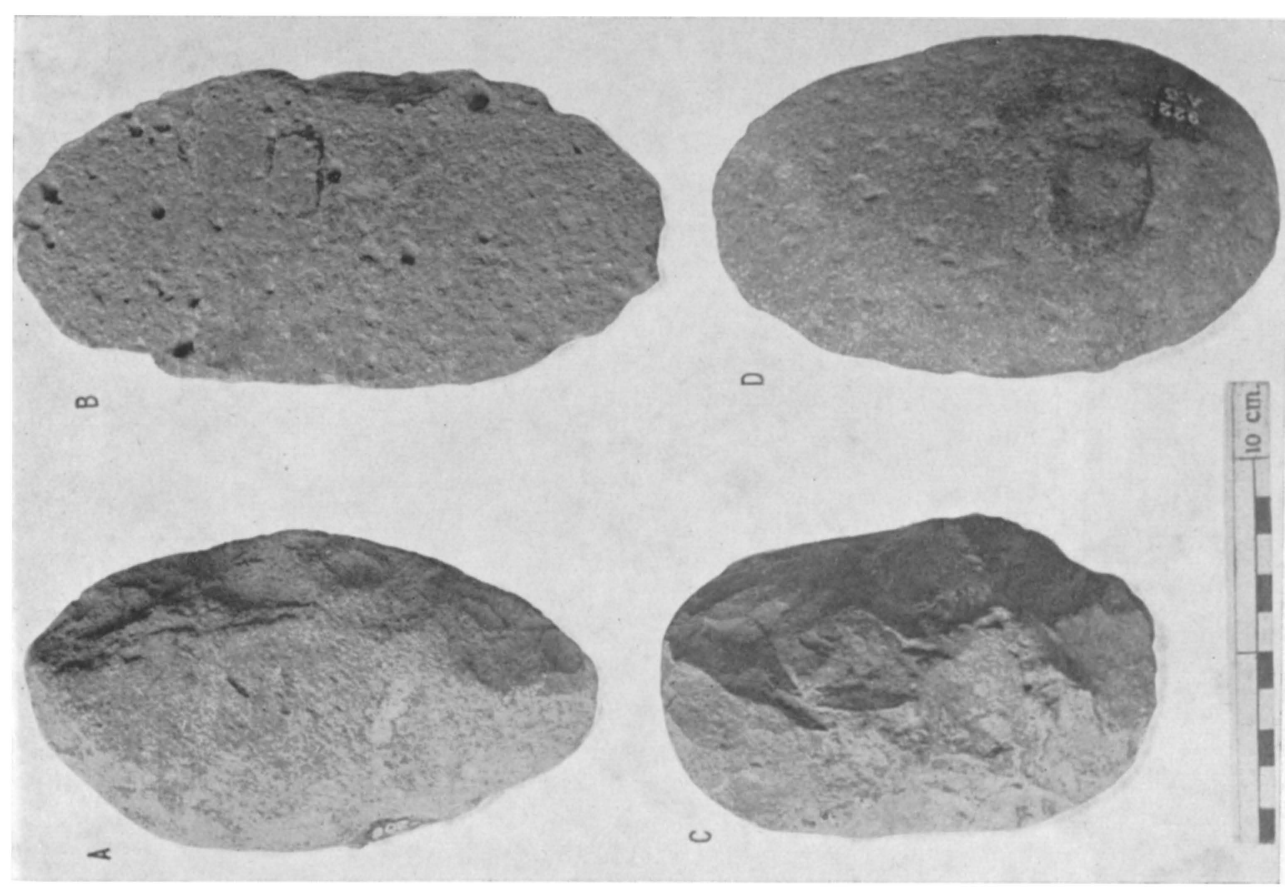

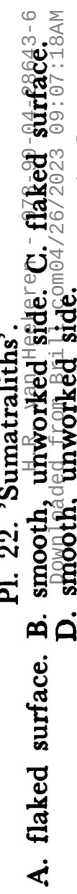
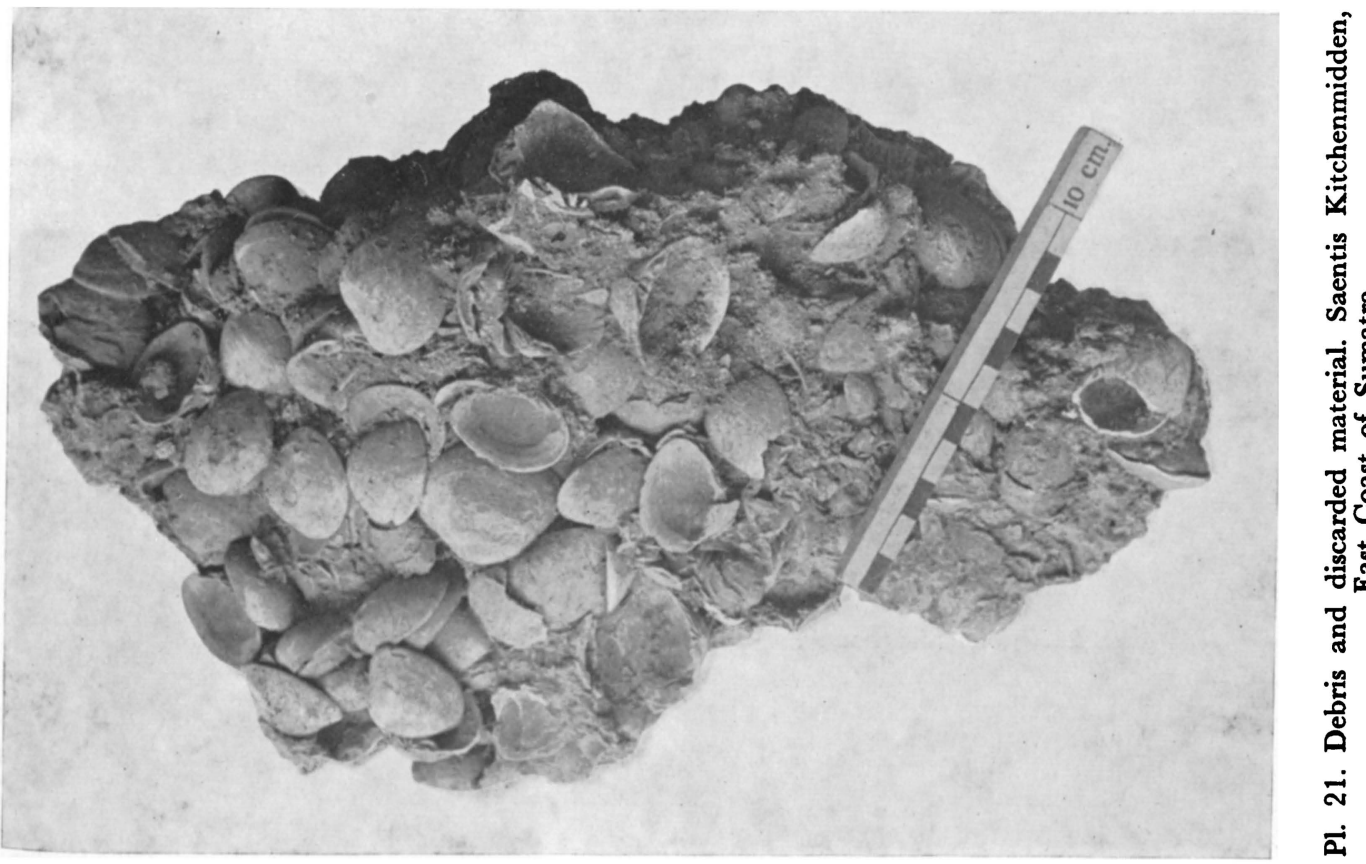


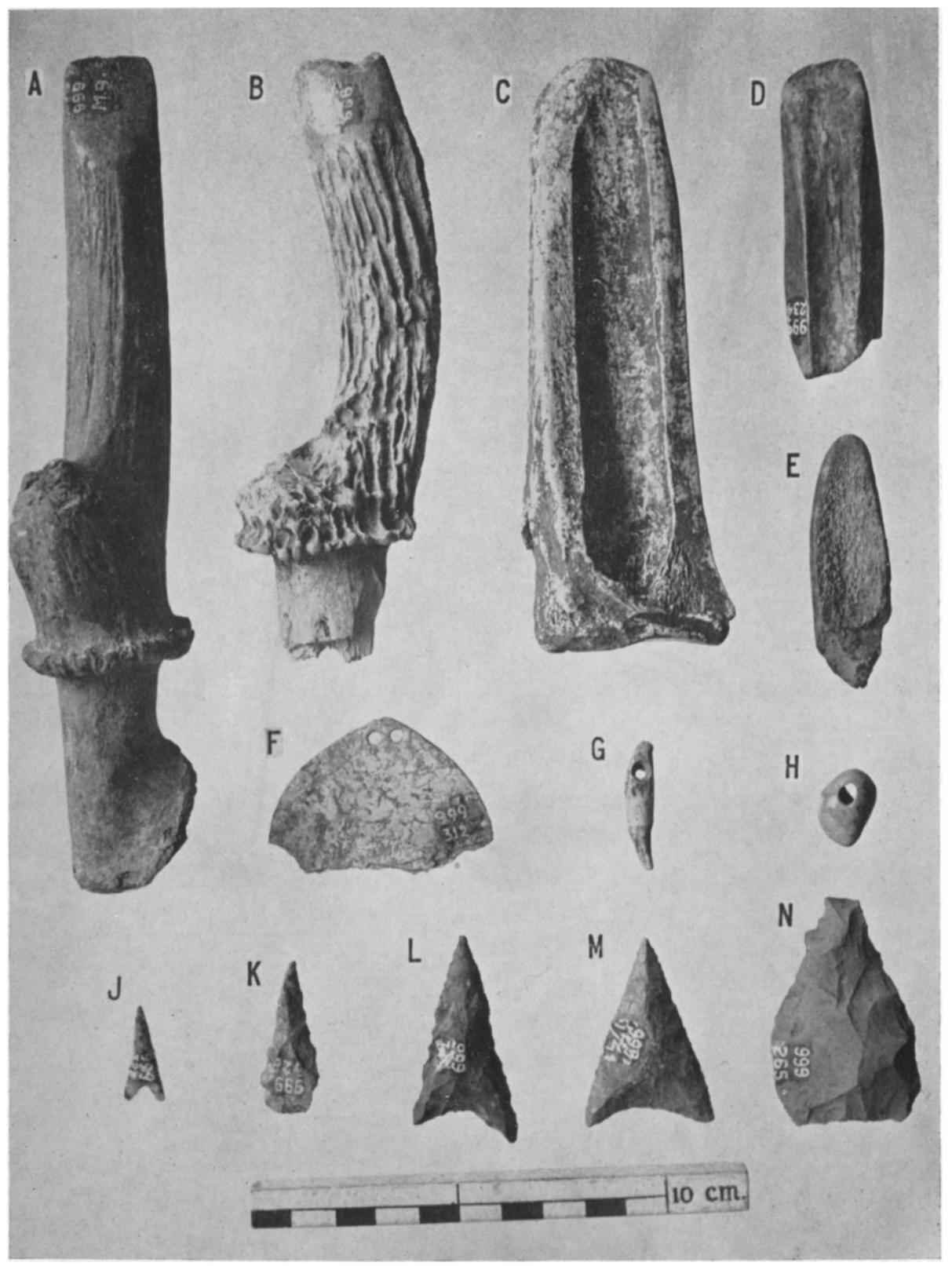

Pl. 23. Stone and bone implements, Lawa Cave, Sampung, East Java. 


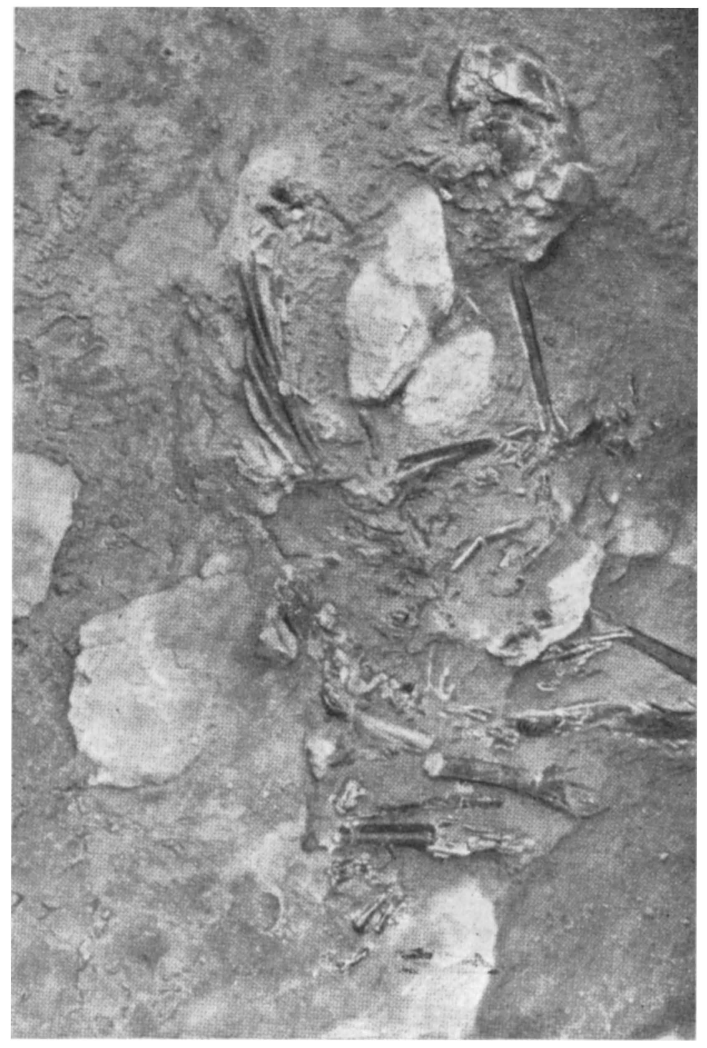

Pl. 24 Human skeleton (flexed burial), Gua Lawa, Java.
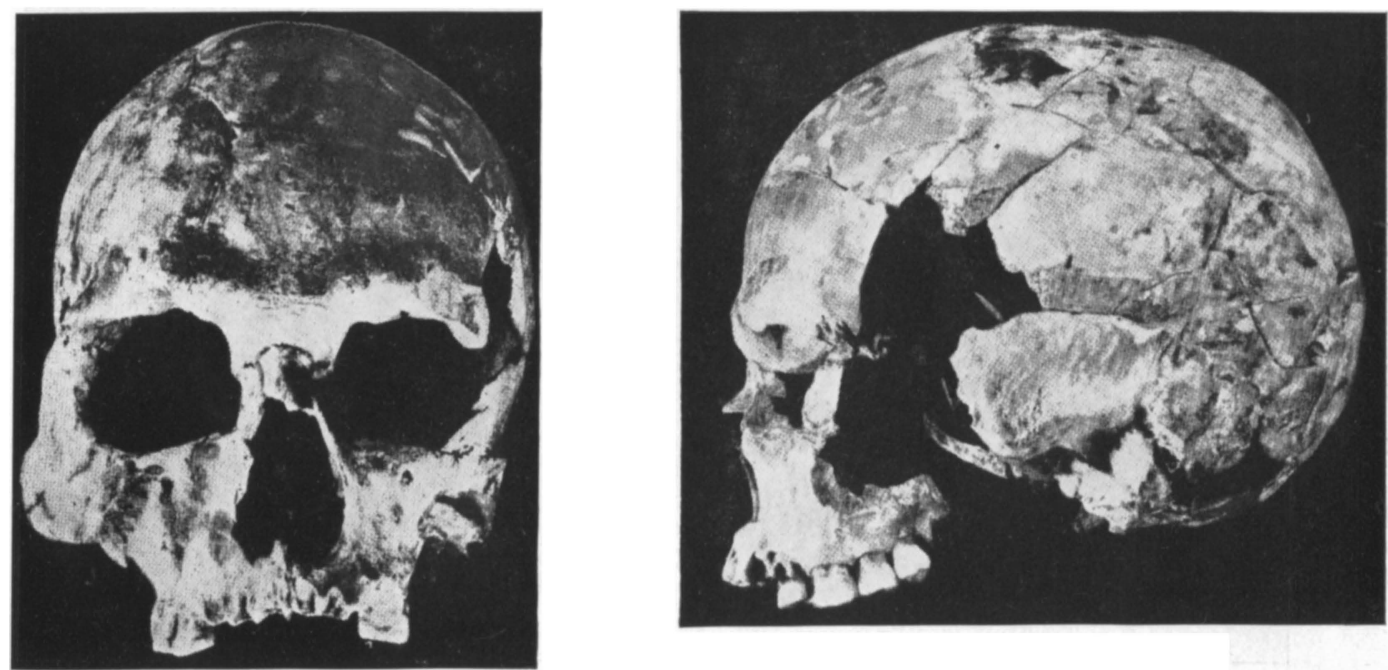

P1. 25. Sampung stoull. a f frontal view, b; lateral view. 


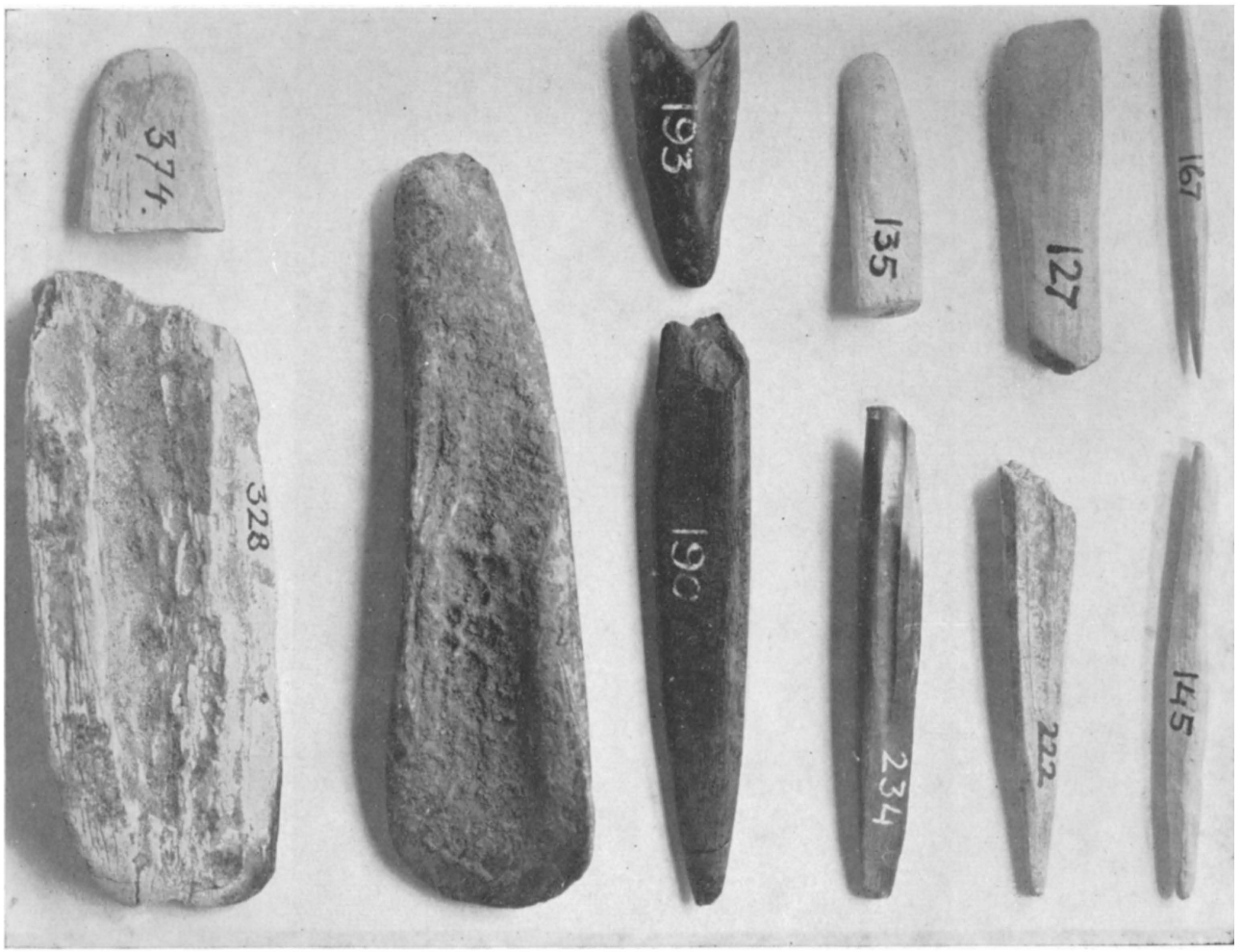

Pl. 26a. Bone implements. Gedeh Care, Tuban, Jara.

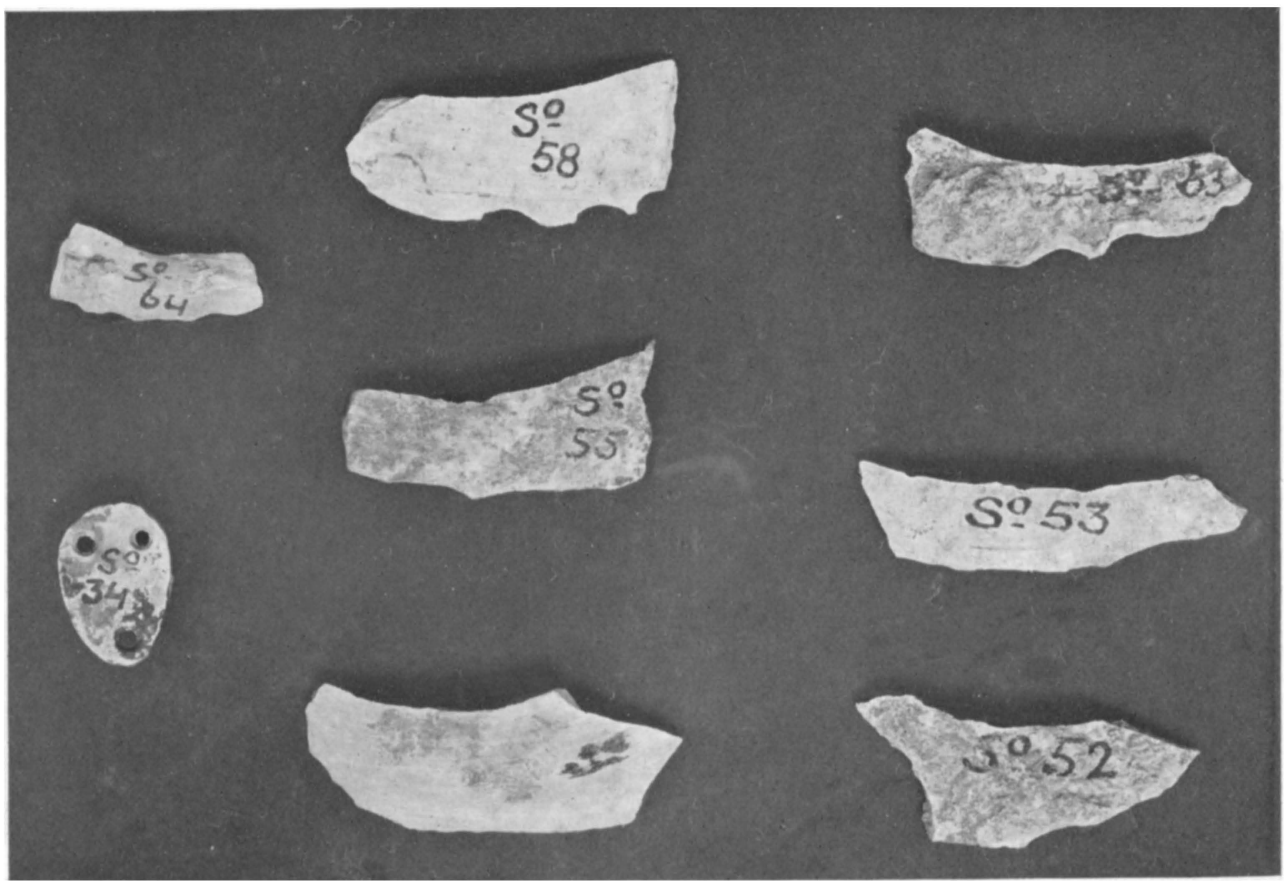

Pl. 26b. Shell implements. Sodong Cave. Puger, Jakraleekeren - 978-90-04-28643-6 Downloaded from Brill.com๑4/26/2023 09:07:18AM 


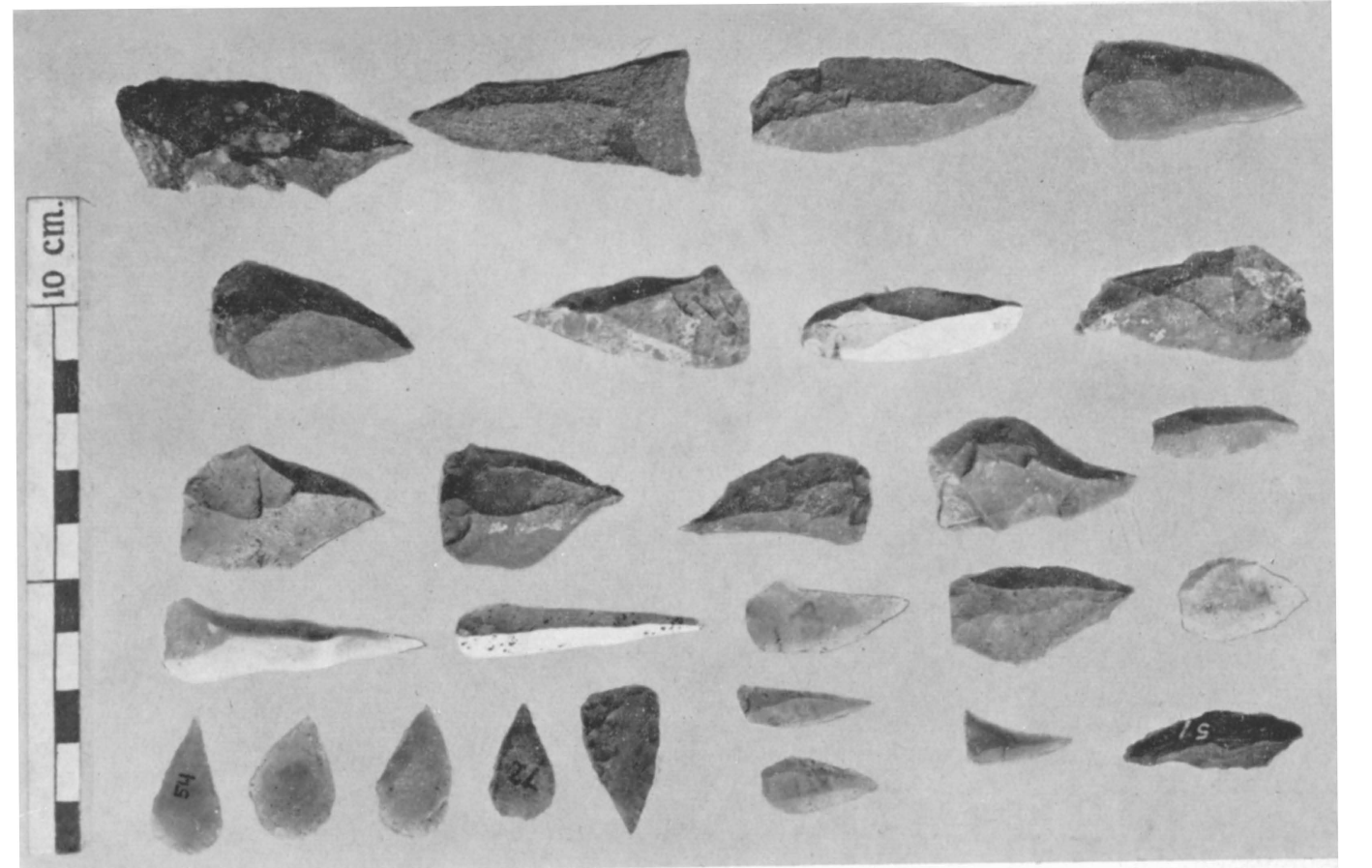

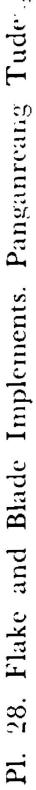

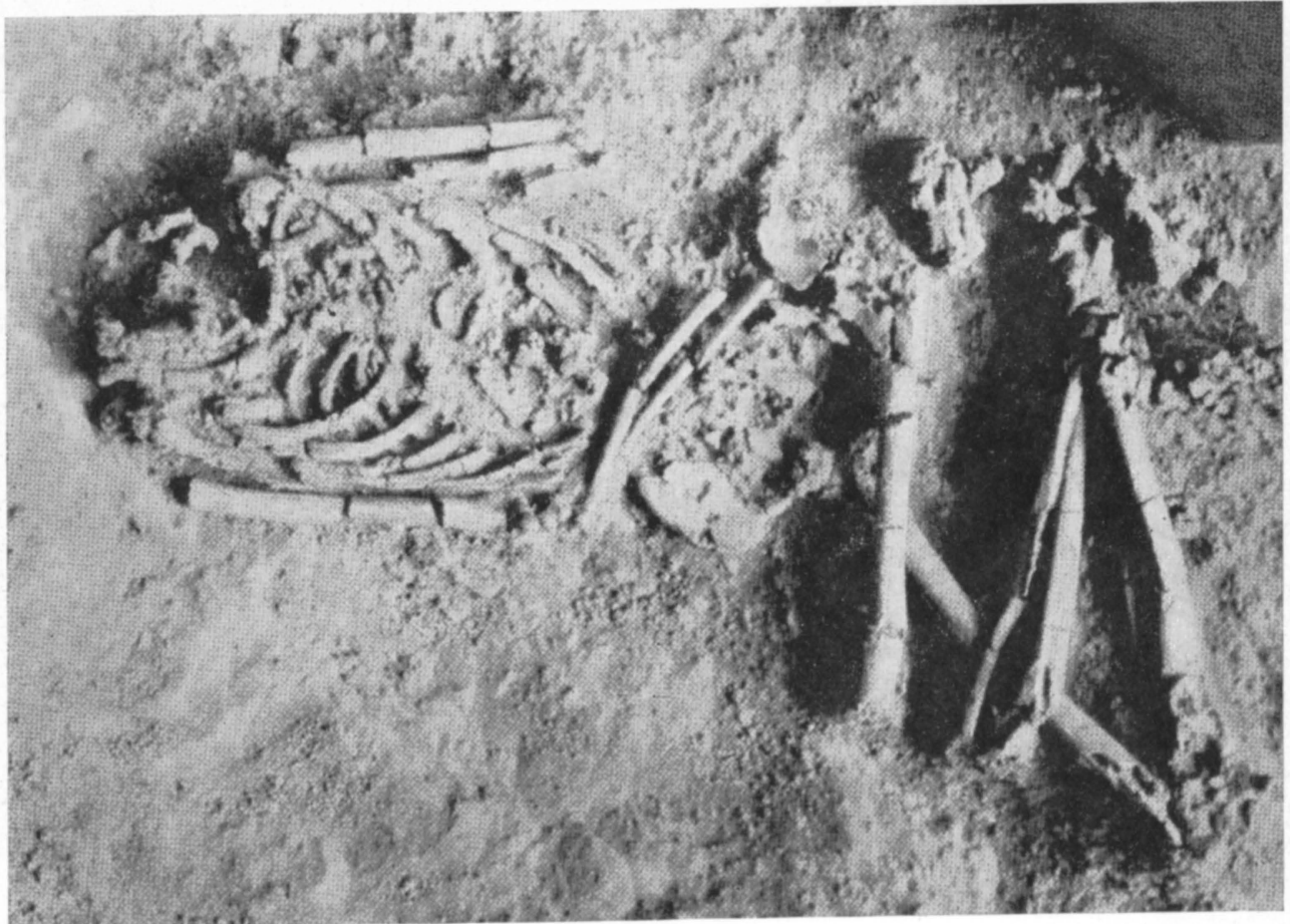

 

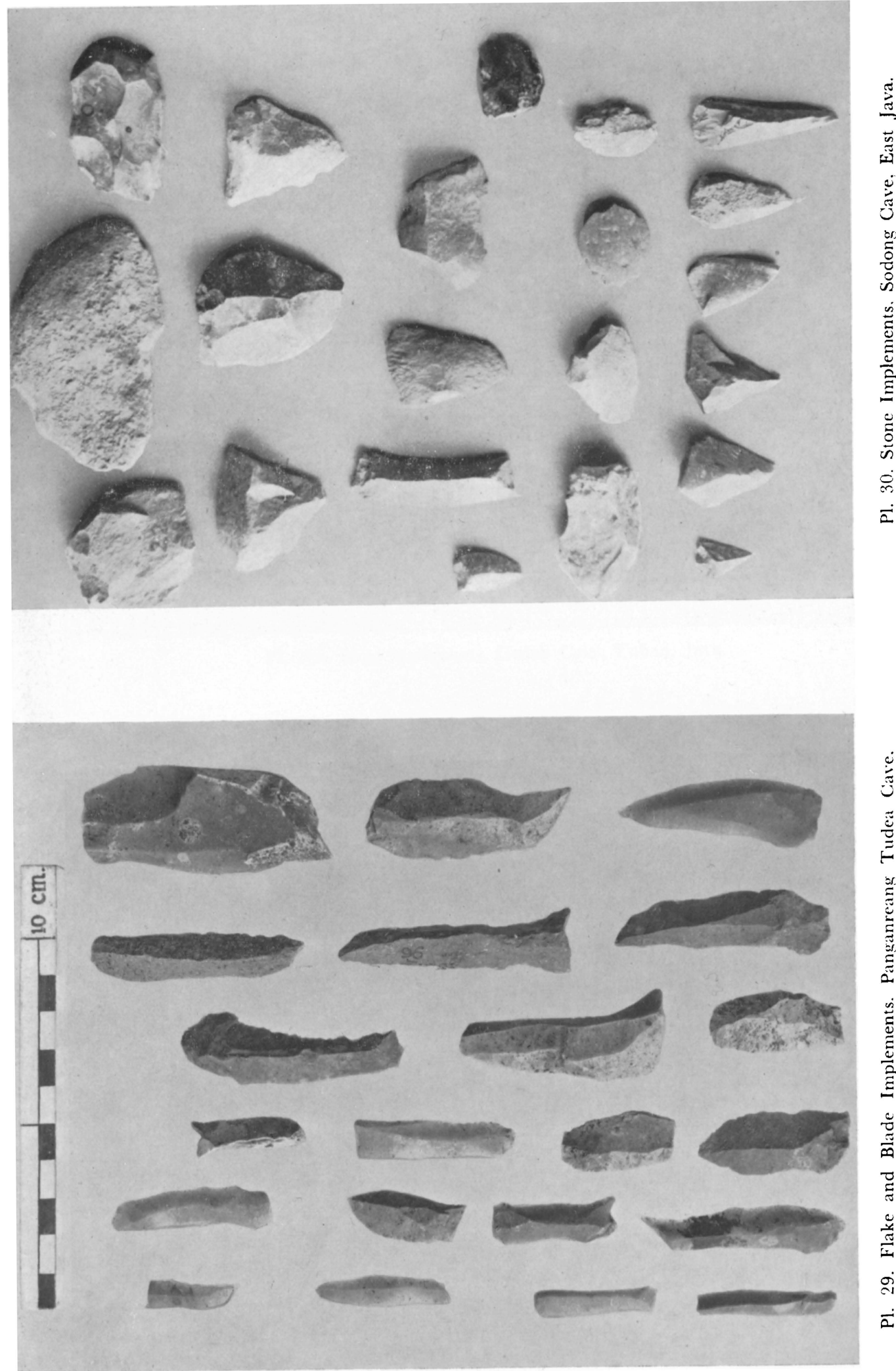

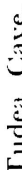




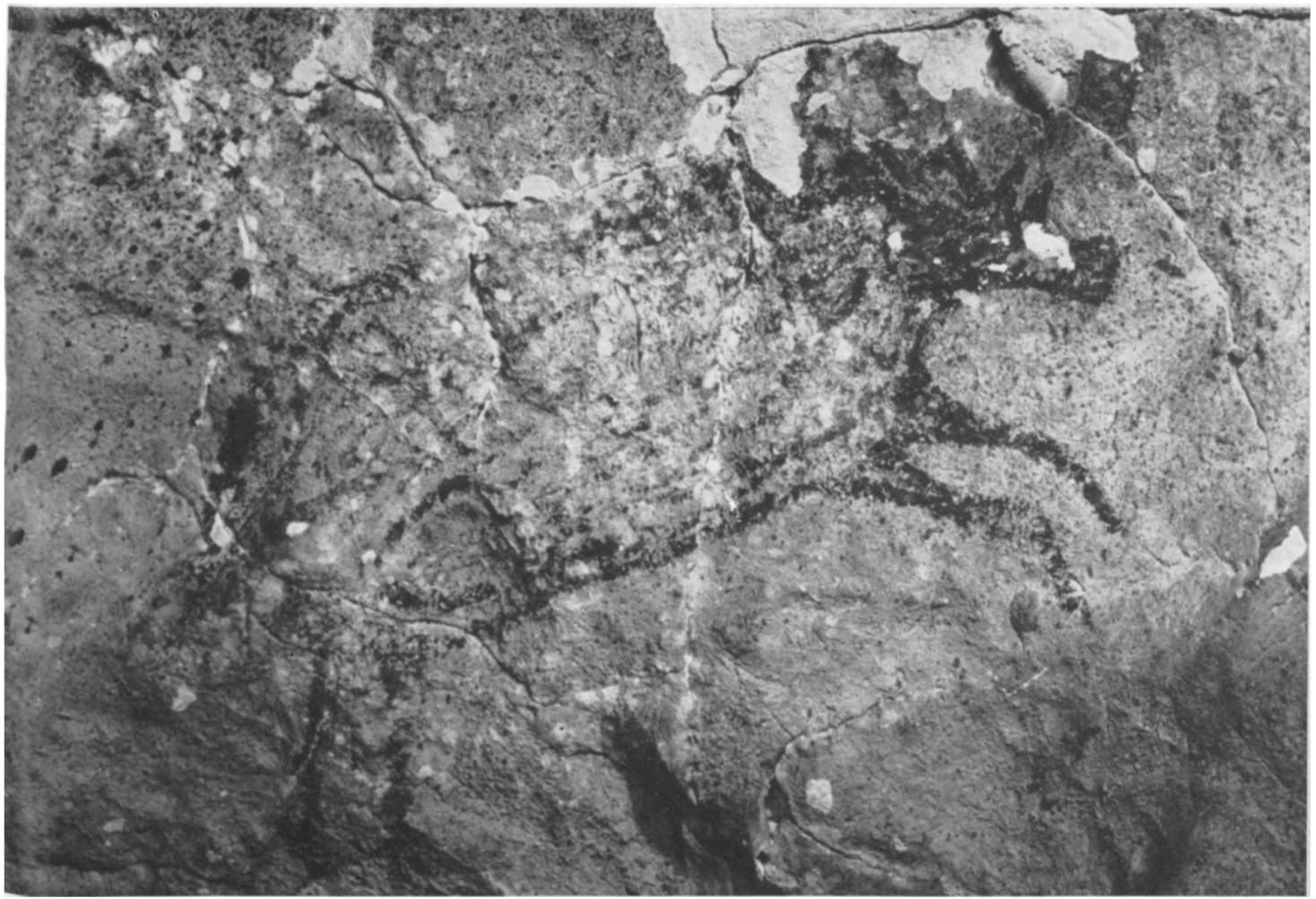

PI. 31. Rock-painting of a boar in red striped line technique. PattaE Cave. East of Maros, Sth. Celebe

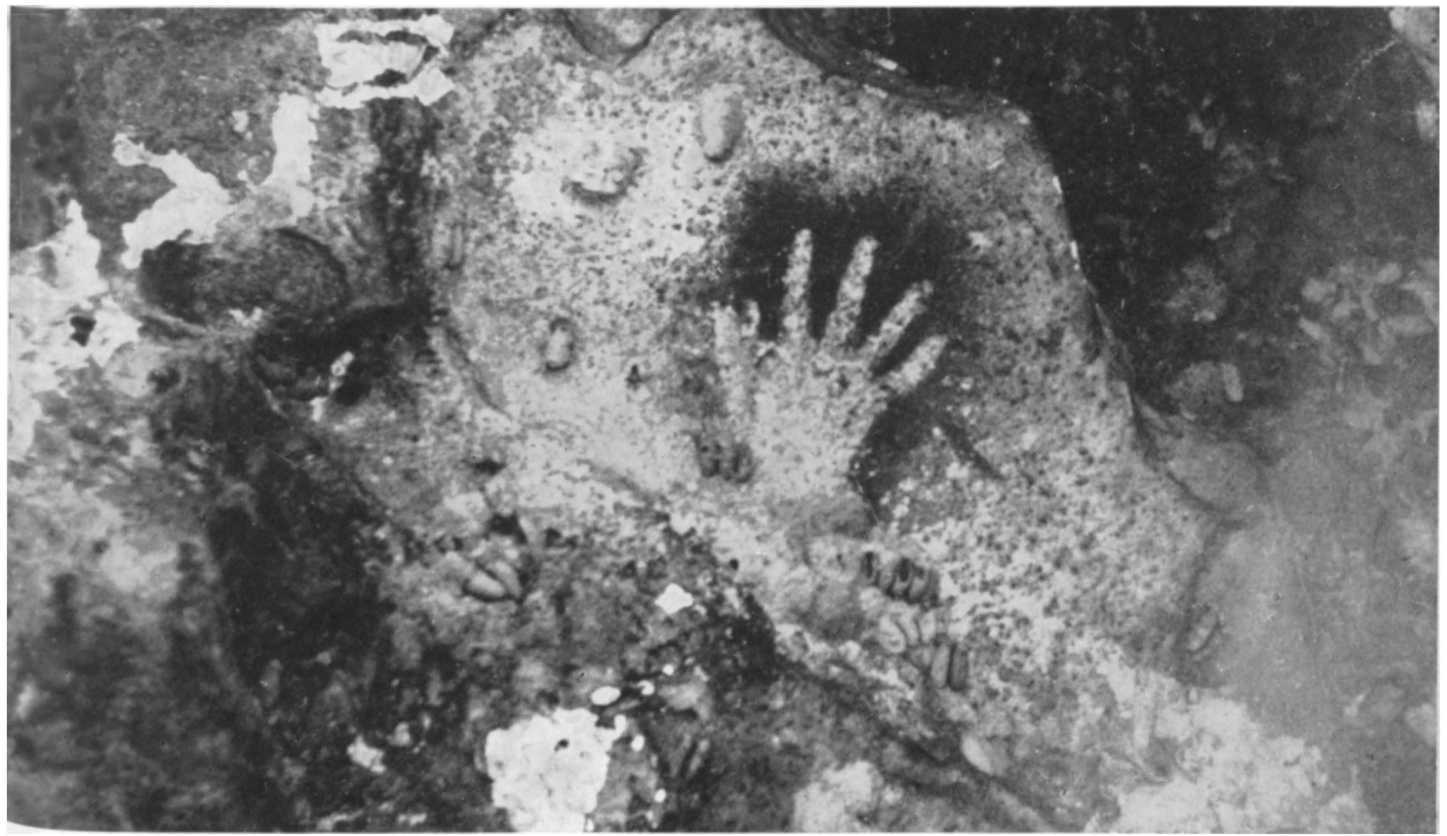

PI. 32. Negative Hand-stencil on a red background. Burung Cave. East of Maros. Sth. Celebes. 


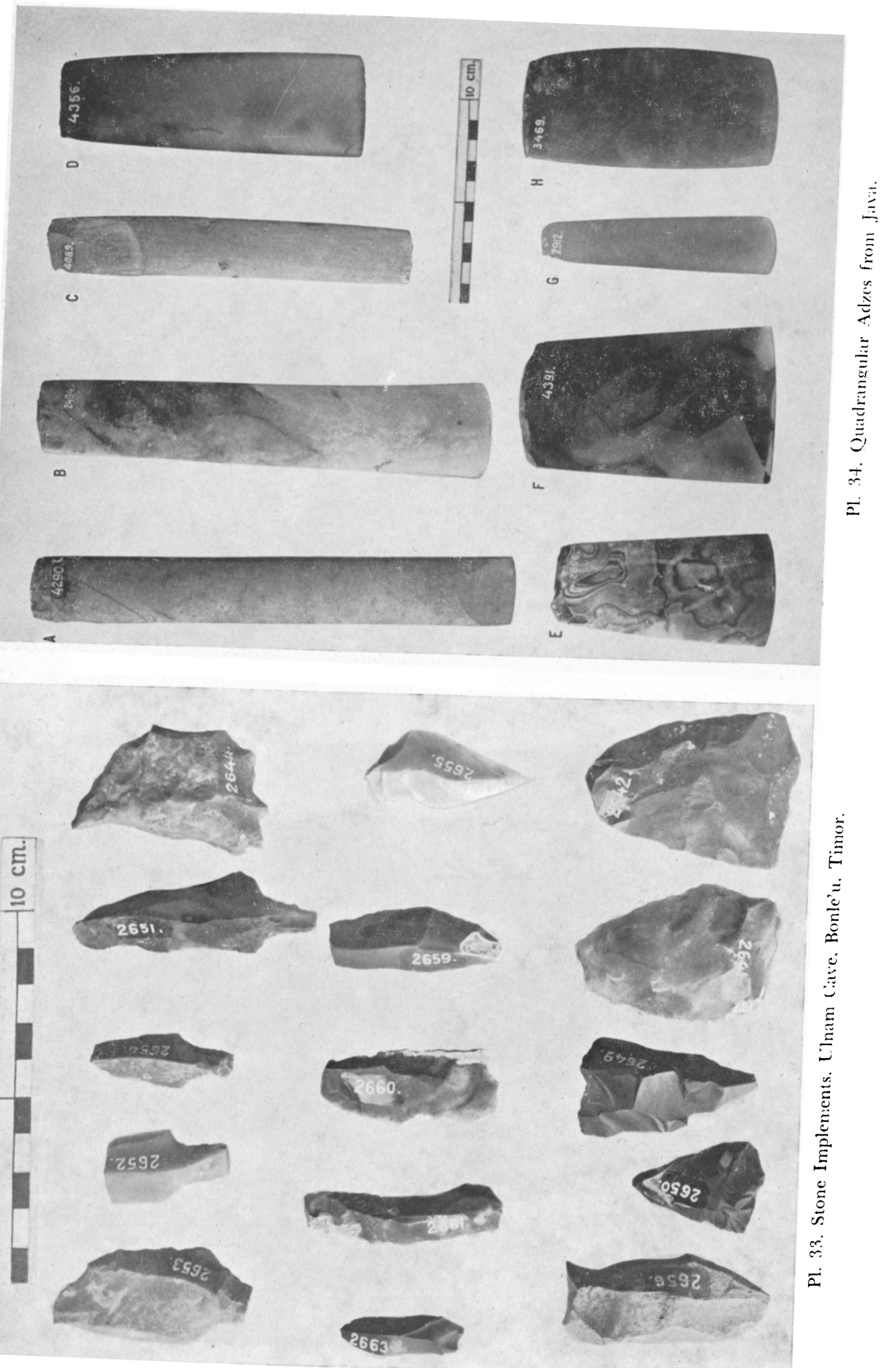


c)

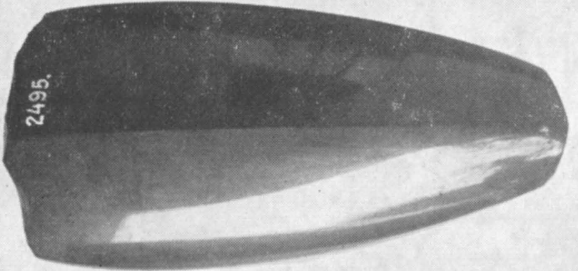

$\infty$

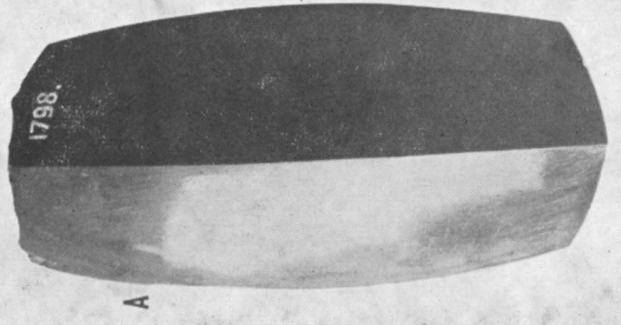

L.

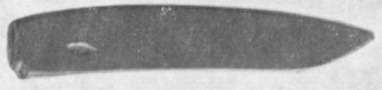

w

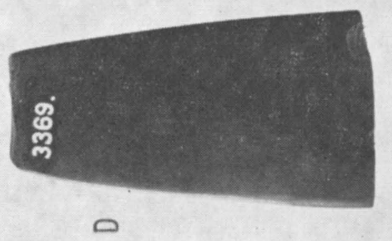

○

$\stackrel{\mathscr{N}}{*}$

总

c)
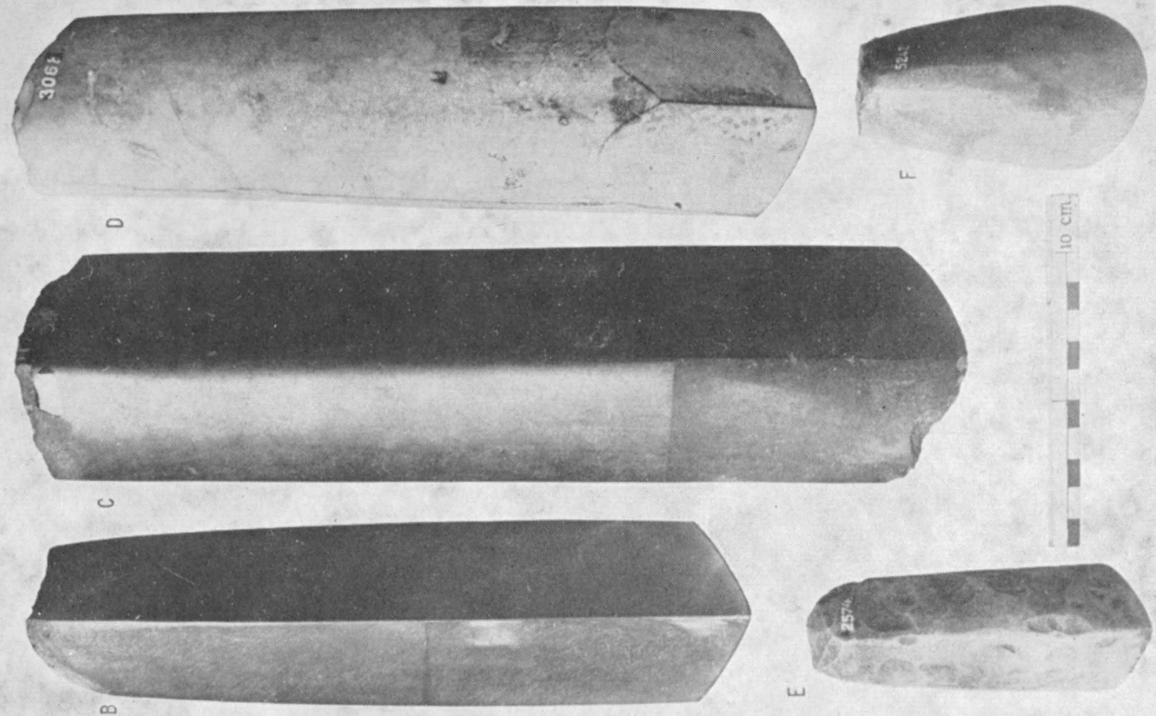

$\stackrel{5}{5}$

ำ

เ

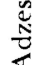

है

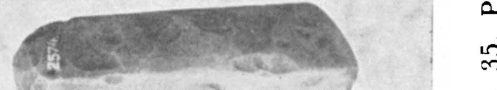

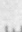

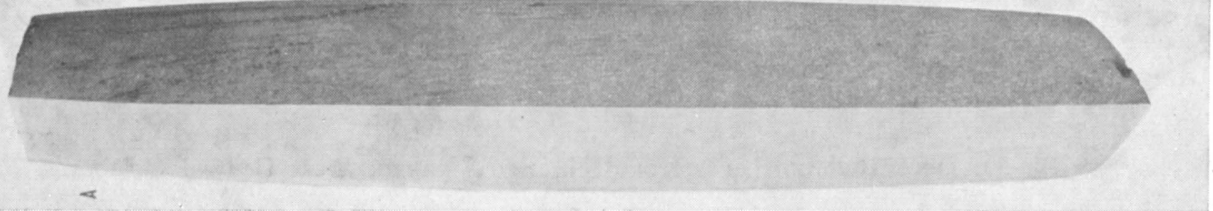



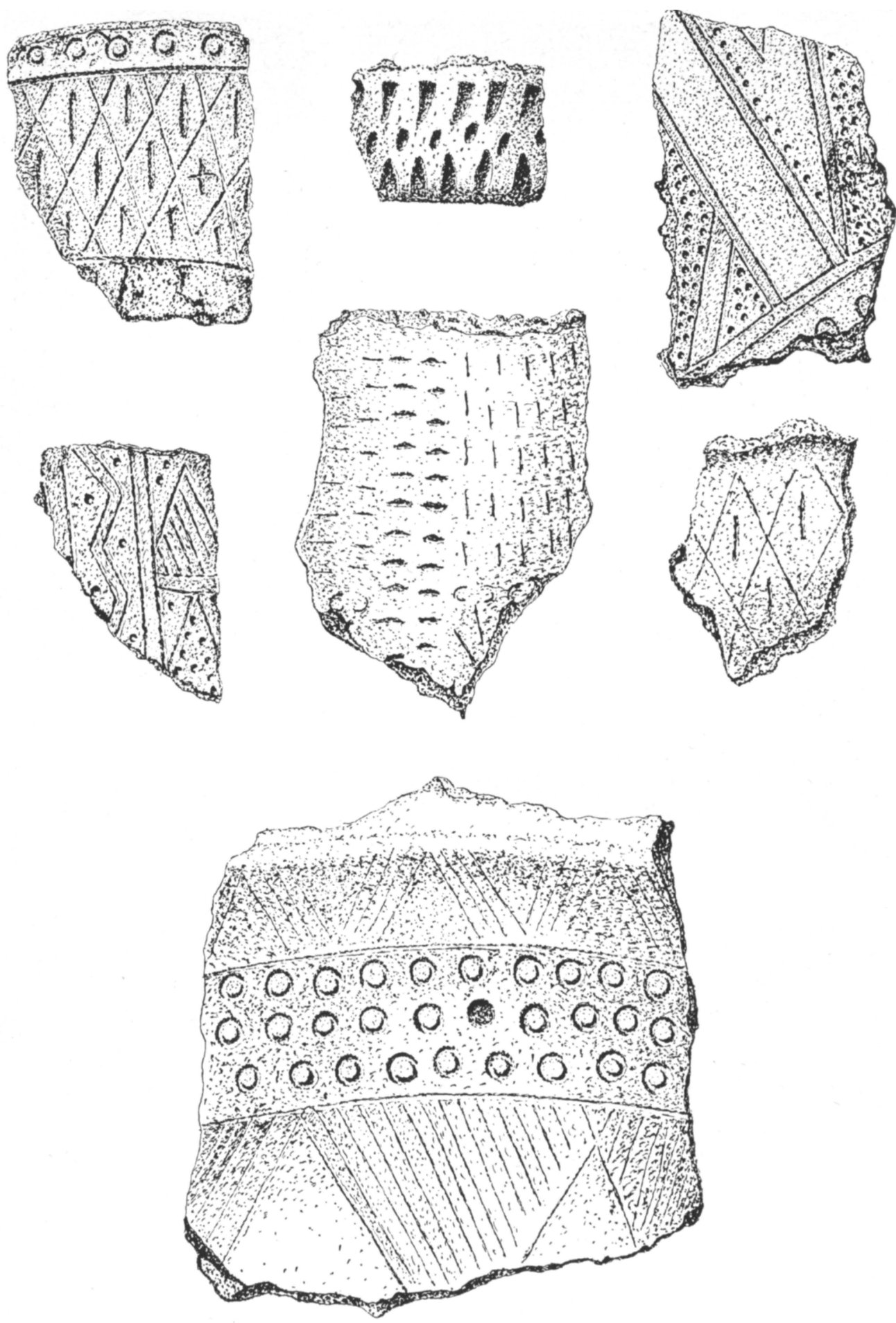

Pl. 37. Decorated potsherds from Minango Sipakko. West Central Cielebes. 


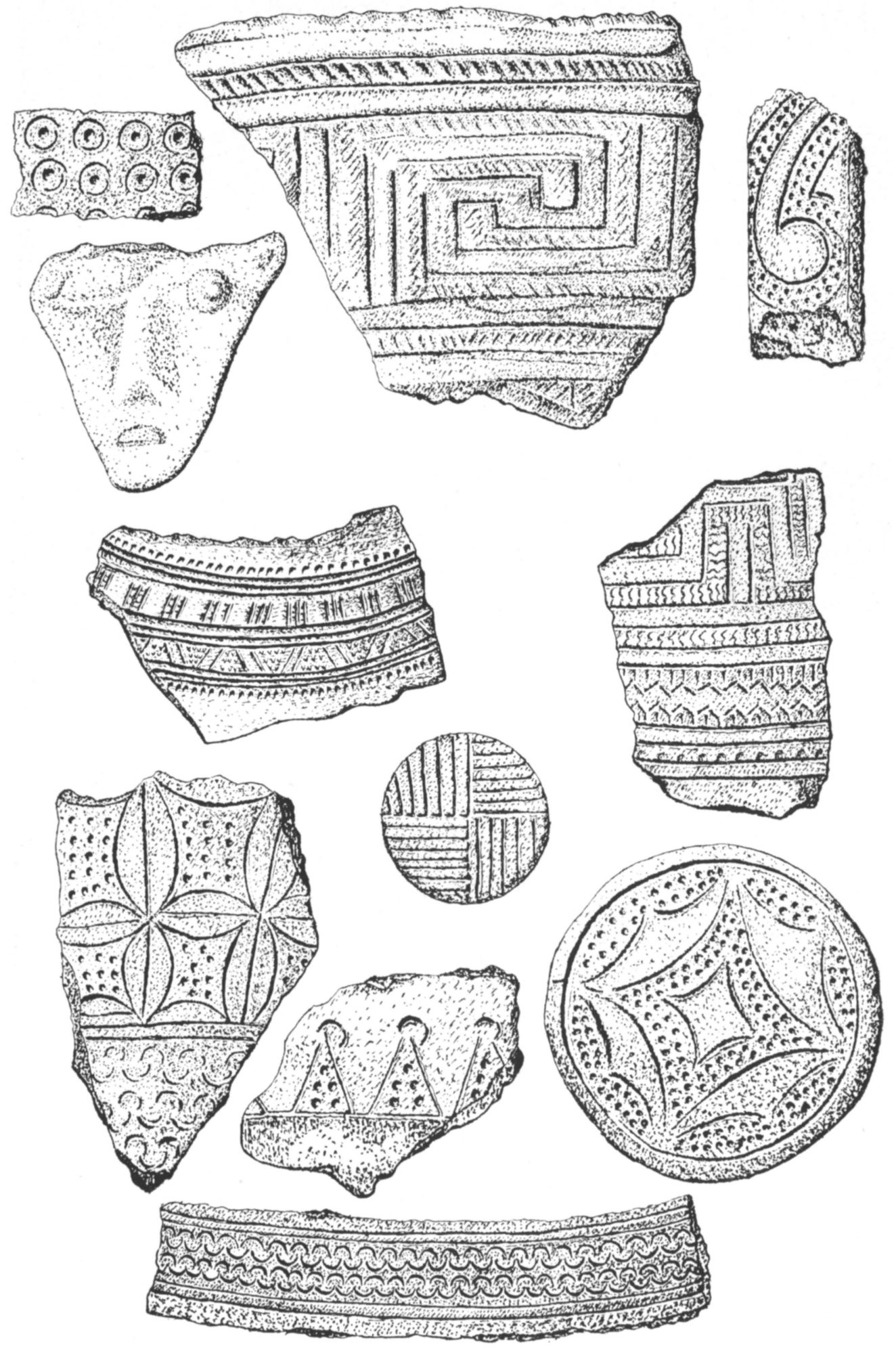

Pl. 38. Decorated potsherds from Kalumpang. West Central Celebes. 


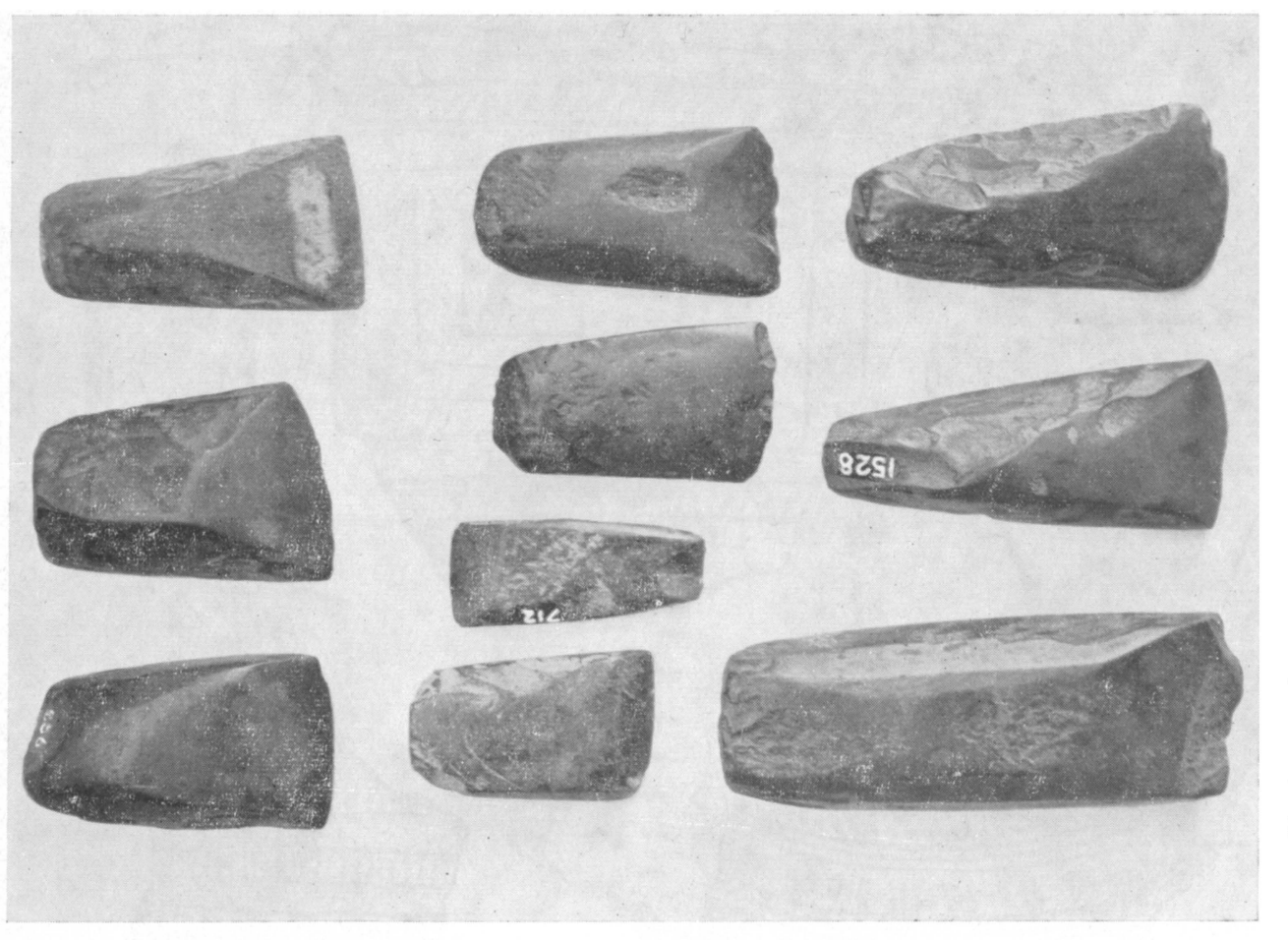

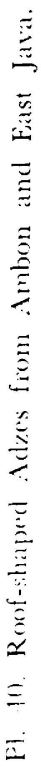

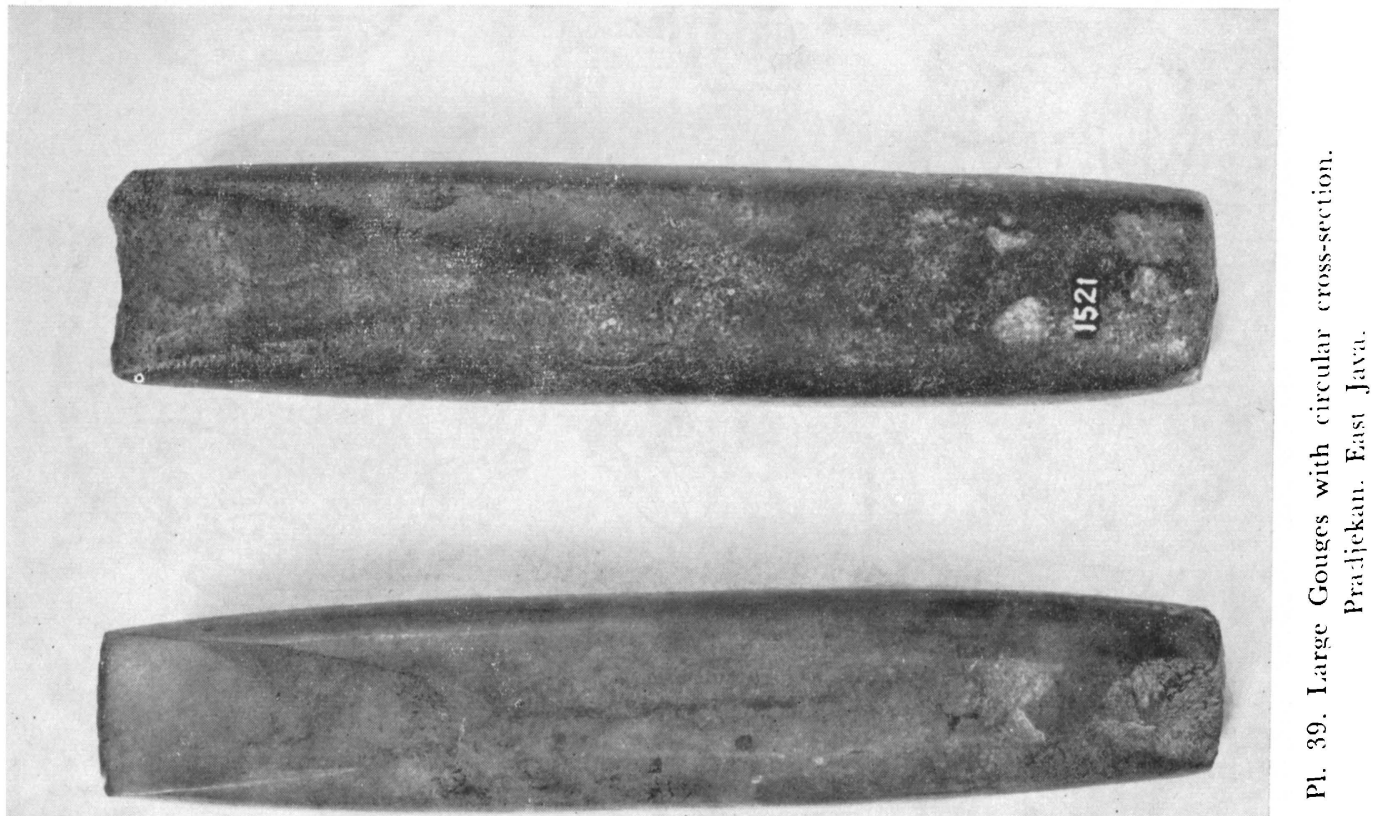



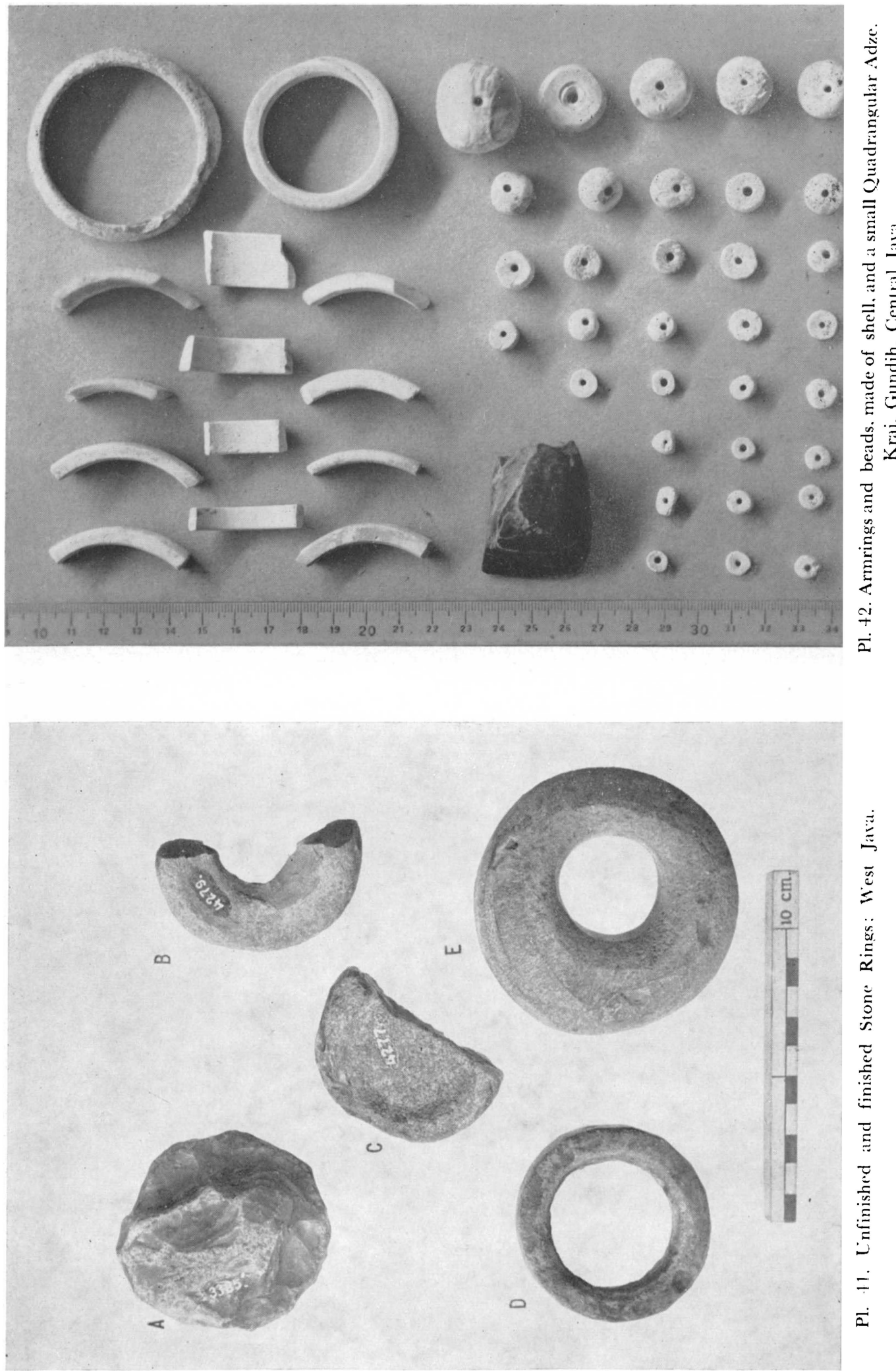


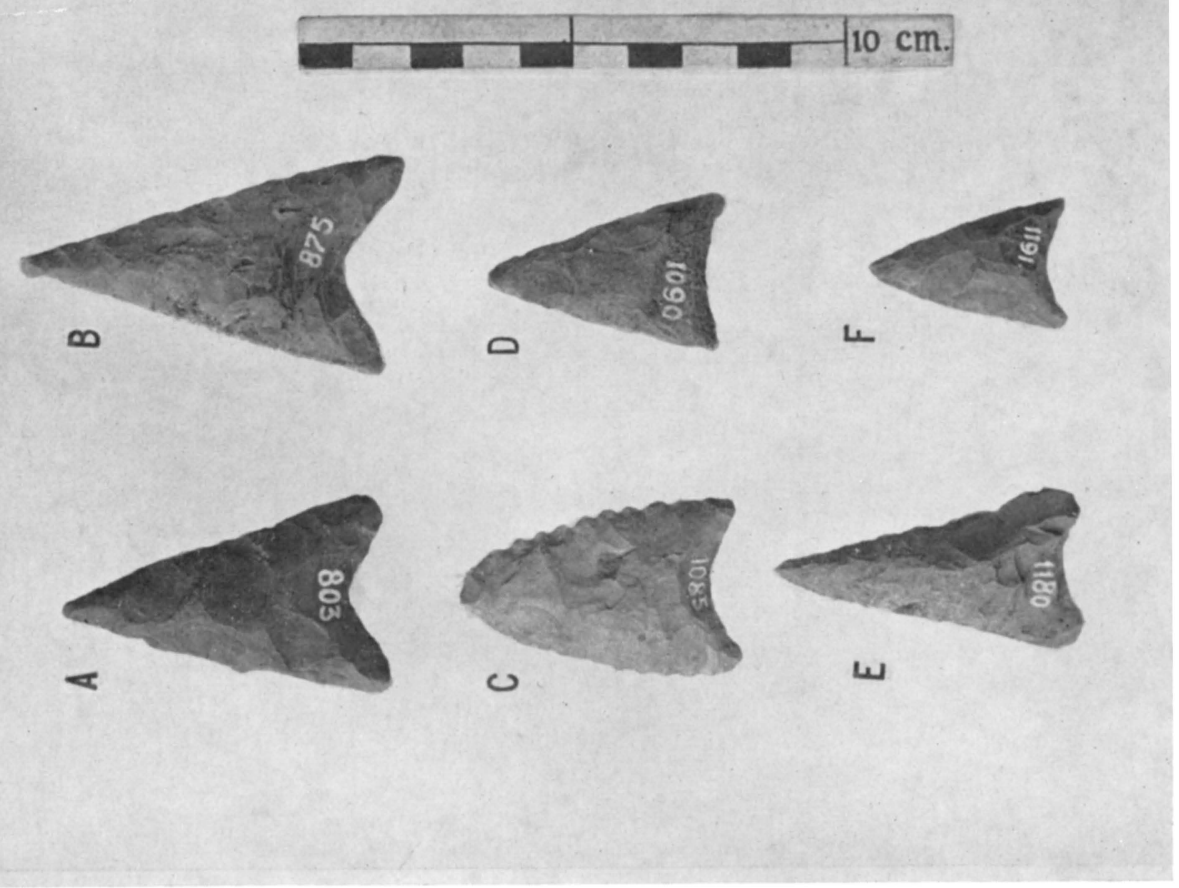

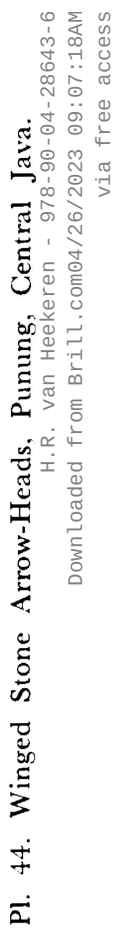
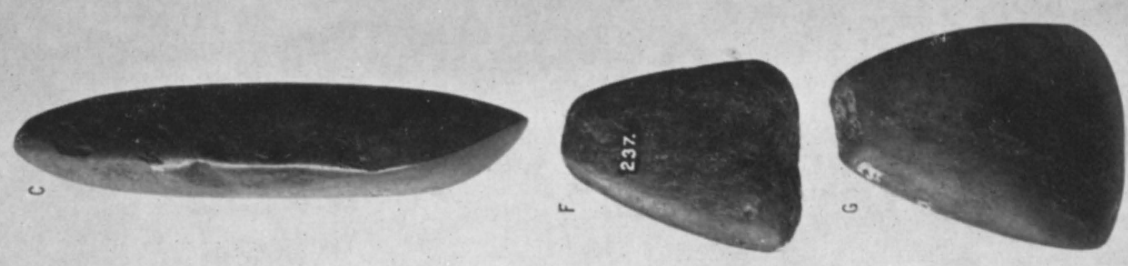

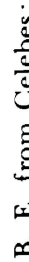
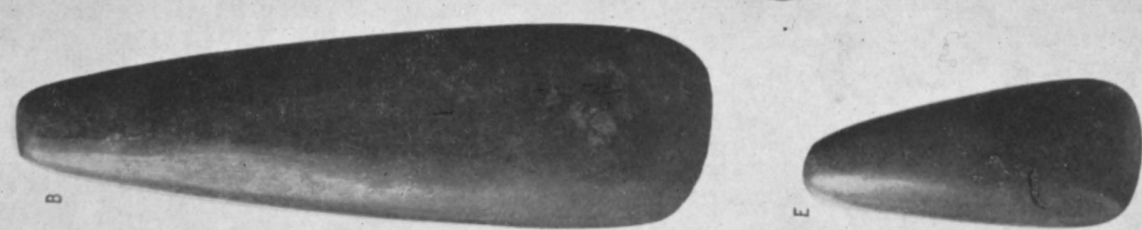

胥

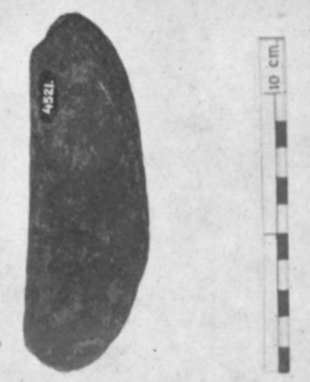

पू

ह

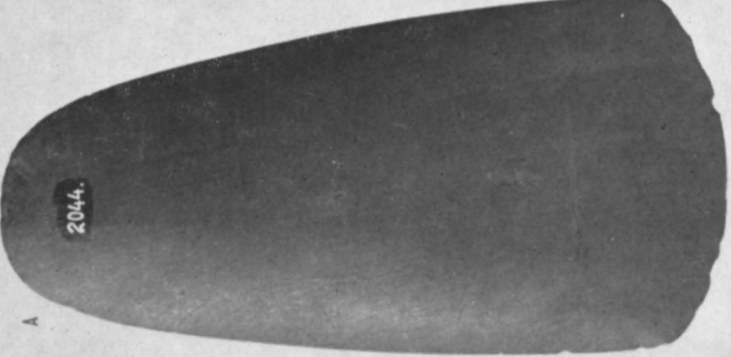

$\dot{a}=$

ن

is

$\ddot{\ddot{x}}$

Ð

$\stackrel{2}{+}$ 

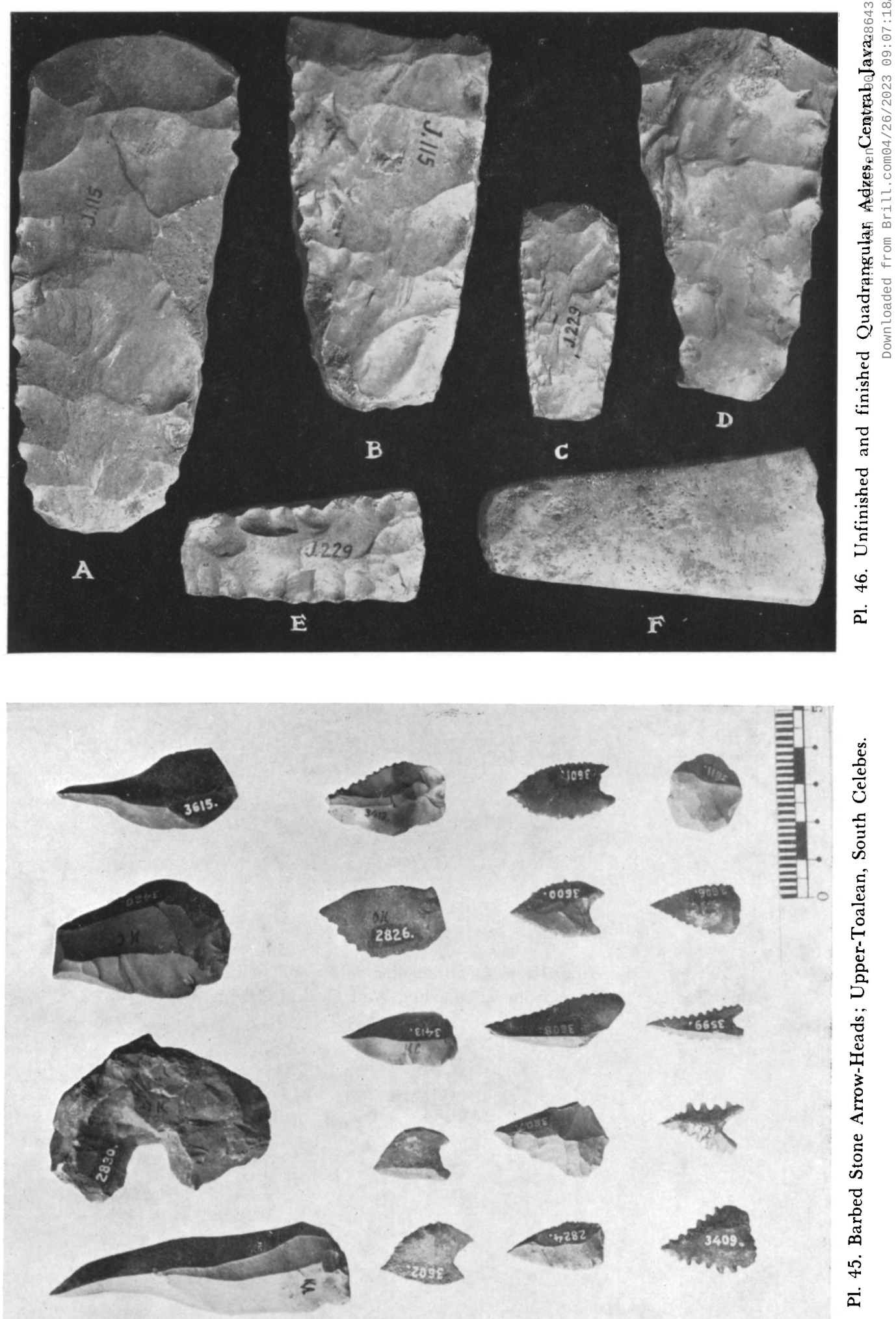


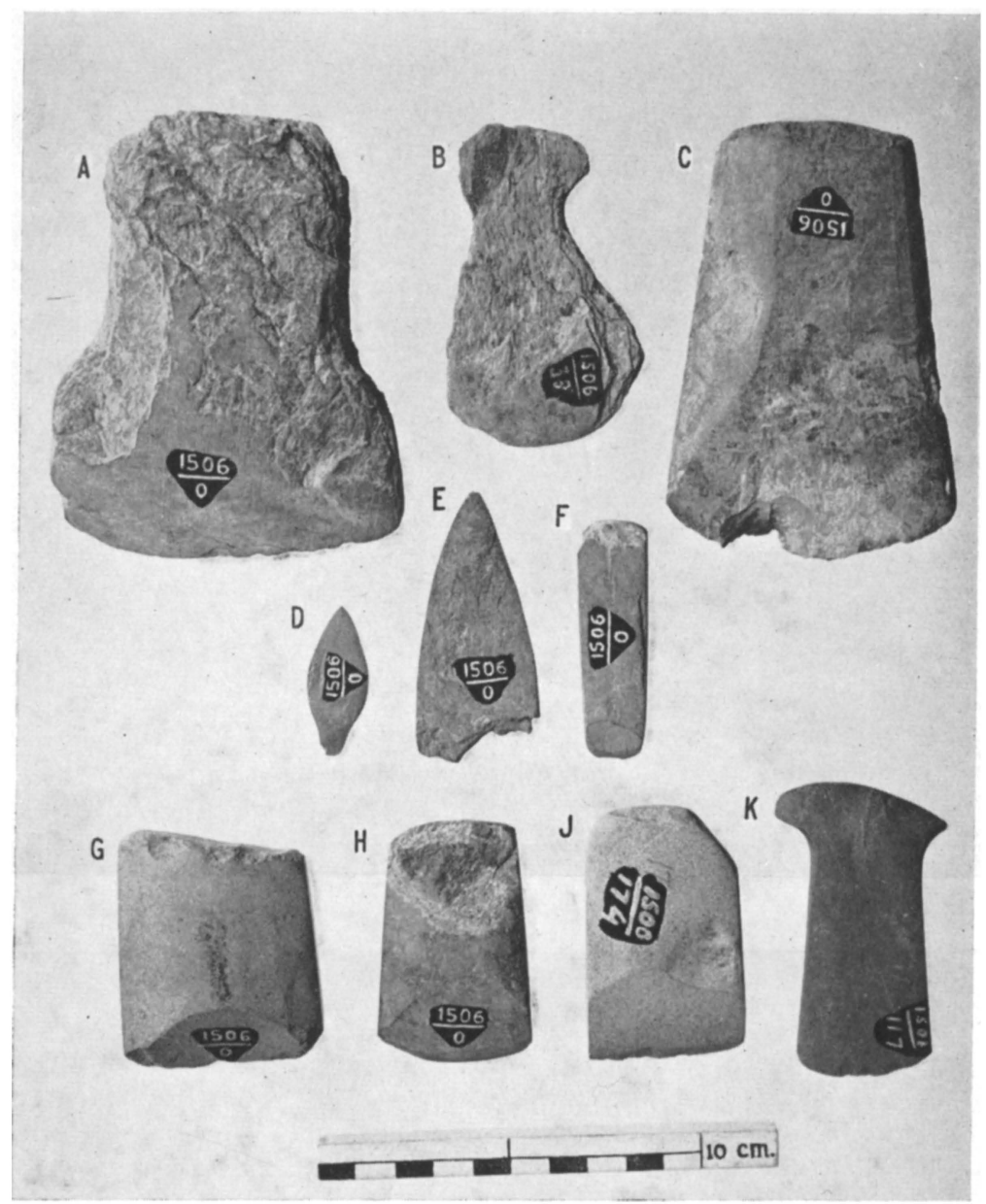

Pl. 47. Violin-shaped and Quadrangular Adzes and polished stone Arrow-Heads from Kalumpang. West Central Celebes. 